\title{
Architectural Survey of Pence Elementary School, Fort Leonard Wood, Missouri
}

Sunny Adams, Chris J. Cochran, and Adam Smith

September 2011

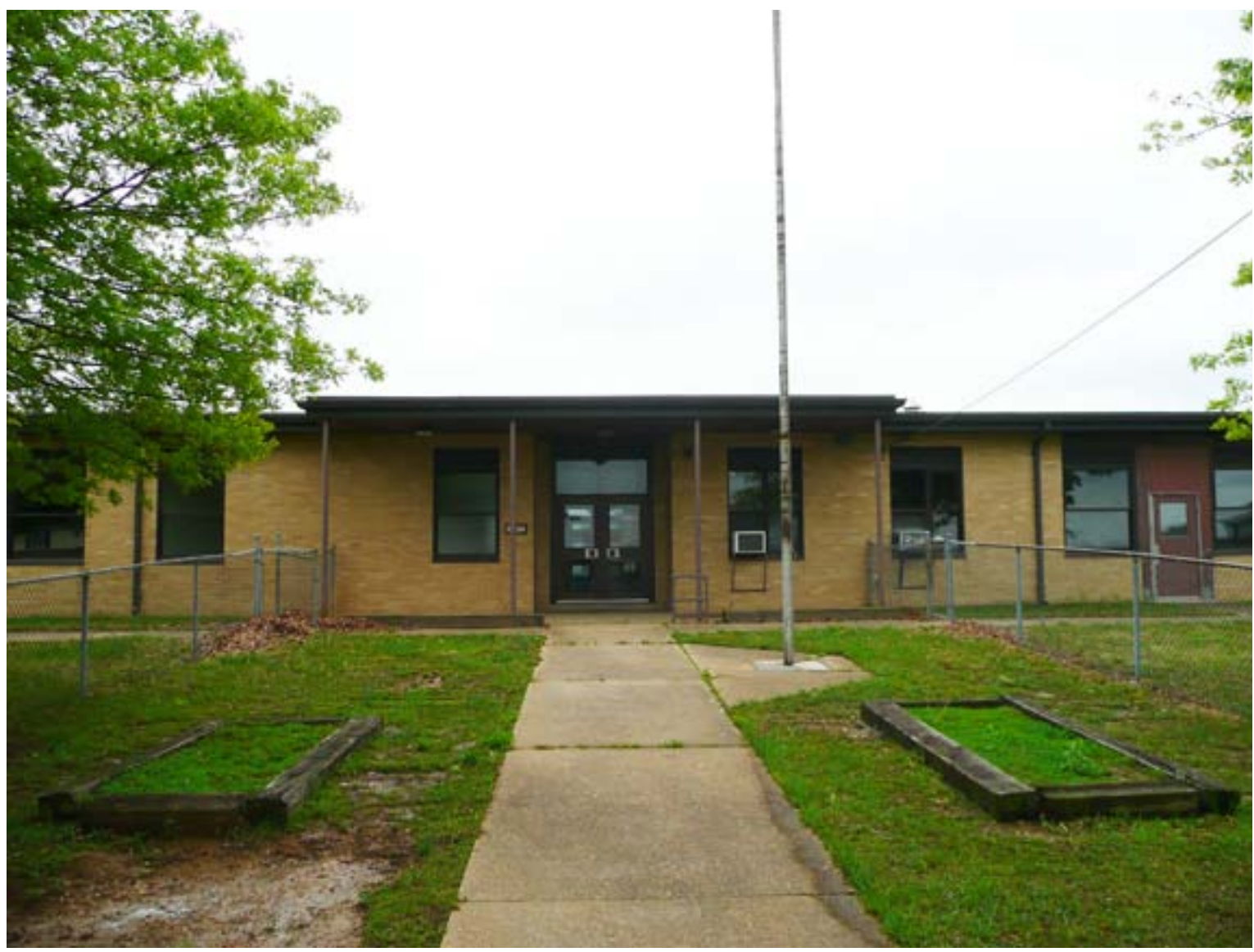





\section{Architectural Survey of Pence Elementary School, Fort Leonard Wood, Missouri}

Sunny Adams, Chris J. Cochran, and Adam Smith

Construction Engineering Research Laboratory (CERL)

U.S. Army Engineer Research and Development Center (ERDC)

2902 Newmark Dr.

Champaign, IL 61822-1076

Final Report

Approved for public release; distribution is unlimited.

Prepared for Fort Leonard Wood

Directorate of Public Works Environmental Division

Fort Leonard Wood, Missouri 65473 


\begin{abstract}
This document is an architectural survey of Building 6824, Pence Elementary School, constructed in 1954 at Fort Leonard Wood, Missouri. This survey was initiated for a Section 106 process and satisfies Section 110, both of the National Historic Preservation Act of 1966 as amended. The work was used to determine the eligibility of the school for inclusion on the National Register of Historic Places (NRHP). It is the determination of this report that Pence Elementary School is not eligible to the NRHP because it is not individually significant and is not part of a larger historic district.
\end{abstract}

DISCLAIMER: The contents of this report are not to be used for advertising, publication, or promotional purposes. Citation of trade names does not constitute an official endorsement or approval of the use of such commercial products. All product names and trademarks cited are the property of their respective owners. The findings of this report are not to be construed as an official Department of the Army position unless so designated by other authorized documents. 


\section{Table of Contents}

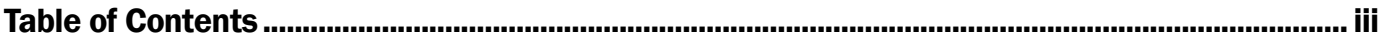

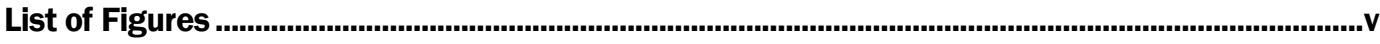

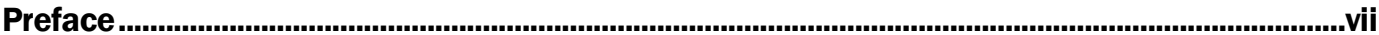

Unit Conversion Factors ................................................................................................................. viii

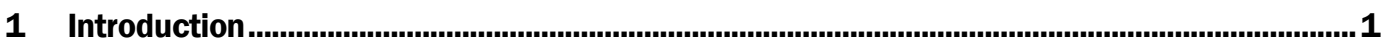

Background

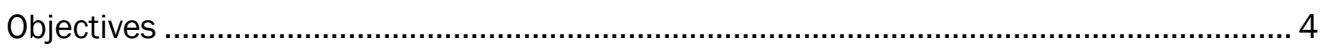

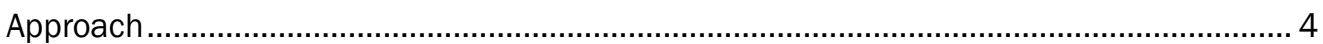

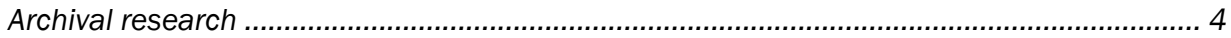

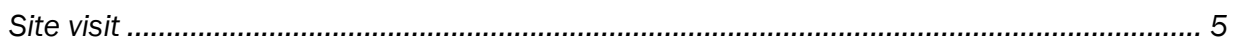

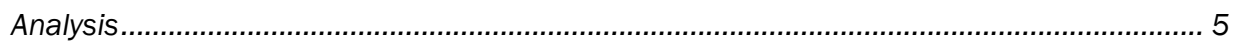

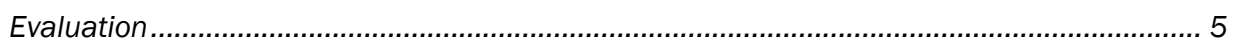

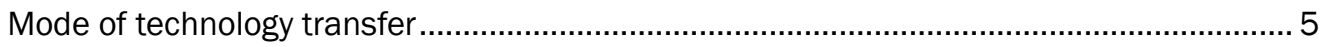

2 Historic Context of Department of Defense Schools........................................................... 7

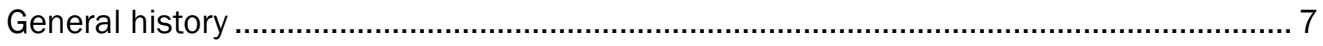

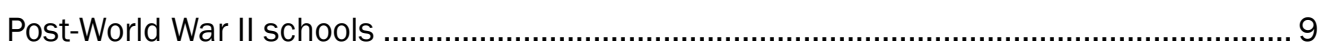

Contemporary architecture of 1950s .............................................................................. 9

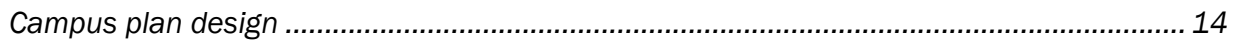

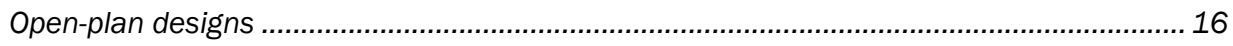

Other design concepts.............................................................................................. 17

First school built under PL 81-874 .......................................................................... 18

Fort Leonard Wood schools .......................................................................................... 19

3 Survey Results .....................................................................................................................21

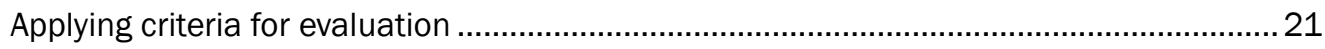

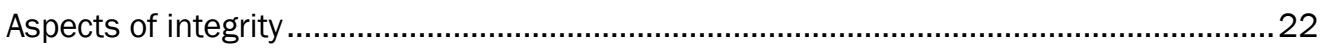

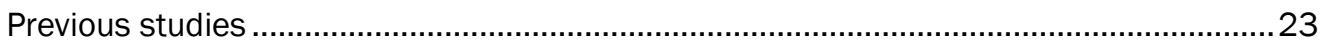

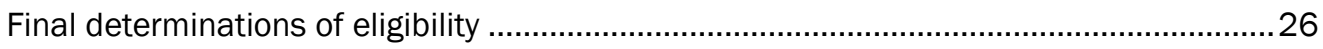

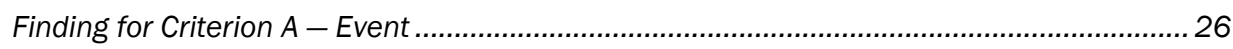

Finding for Criterion B - Person................................................................................ 26

Finding for Criterion C - Design/Construction ...............................................................26

Finding for Criterion D - History................................................................................ 30

Final Determination ................................................................................................. 30

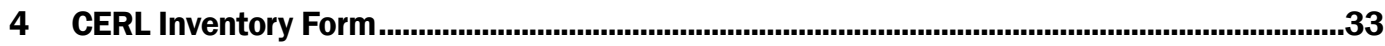

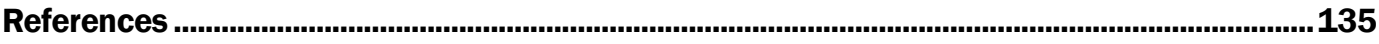

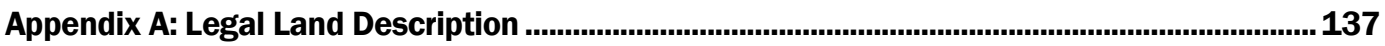


Appendix B: Department of Health, Education, and Welfare - Termination of Permit 1957

Appendix C: Permit for School Purposes

Appendix D: USOE Permit for Use of Real Property by Federal Agency - Permit No. M0-52-C-FED-1A

Appendix E: Return of Pence School, dated April 26, 1994 ......................................................151

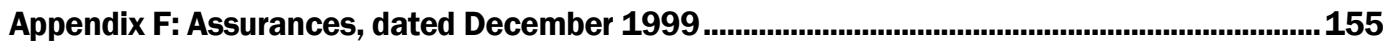

Appendix G: Permit Termination Agreement for Department of Education School

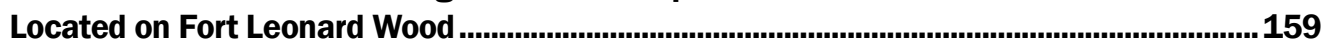

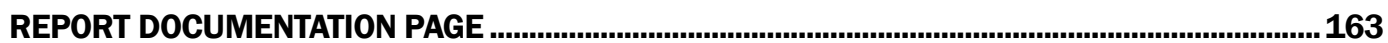




\section{List of Figures}

\section{Figures}

Figure 1. Location of FLW is indicated by the push-pin (Bing maps). ............................................... 2

Figure 2. Map of FLW from July 2000, with Building 6824 indicated by the red box in the upper left corner (FLW Natural Resources Branch)............................................................. 3

Figure 3. One room schoolhouse, c. 1870 (Tanner, 4) . ....................................................................... 8

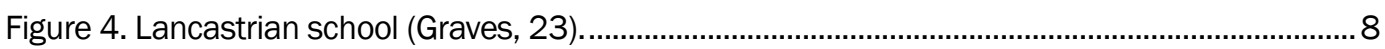

Figure 5. Romanesque Revival style school in Milwaukee, c. 1889 (Tanner, 7) ................................

Figure 6. A 1950s school design featuring a combination of brick with metal and glass

(Two Connecticut, 155)......................................................................................................10

Figure 7. Clerestory windows allow more natural light through the building (Orientation,

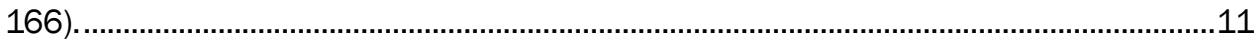

Figure 8. Crow Island School plan (Christ-Janer, 95).....................................................................12

Figure 9. A clock tower divides wings of Crow Island School (Brubaker 1998, 11).........................13

Figure 10. Each classroom at Crow Island has direct access to the outdoors (Christ-Janer,

98).

Figure 11. Old Saybrook High School, site plan of pod design (New Kind of High School, 147).

Figure 12. Old Saybrook High School, birdseye view of pod design (New, 147)................................15

Figure 13. Montgomery Central High School, Cunningham, Tennessee, floor plan

(Sanders). 15

Figure 14. Montgomery Central High School, Cunningham, Tennessee (Sanders)...........................16

Figure 15. Disney School site plan (Tanner 2006, 16) . .................................................................17

Figure 16. Disney School open classroom (Tanner 2006, 17) . ........................................................17

Figure 17. Lincoln Elementary and Public Law 81-874 (ERDC-CERL)..............................................18

Figure 18. Lincoln Elementary School, Fort Campbell, Kentucky (ERDC-CERL). ...............................19

Figure 19. Rolling Heath School, constructed in 1912, is currently the oldest building located at Fort Leonard Wood (ERDC-CERL2004).

Figure 20. North elevation with main entrance and wall of windows; original drawing on the left from 1954 with origial five-pane awning windows compared to the current replacement doors, sidelights, transom, and metal double-hung windows in photo on the right.

Figure 21. Window comparison: original drawing on the left from 1954, showing five-pane awning type windows compared with photo on the right, showing current replacement metal double-hung windows and a newer door opening filled with a metal door and metal siding .

Figure 22. Southwest entrance elevation: original drawing on the left from 1954 compared to the current replacement doors, sidelights, and transom in photo on the right

Figure 23. Entrance on south elevation: original drawing on the left from 1954 compared to the current replacement doors and transom in photo on the right. 
Figure 24. Entrance into the cafeteria on the east wall: original drawing on the left from 1954 compared to the current replacement door, transom, and windows in photo on the right.

Figure 25. Right side of the west elevation: original drawing on the left from 1954 compared to the current replacement door, transom, and windows in photo on the right.

Figure 26. Cafeteria addition: original drawing on the left from 1954 with no expanded cafeteria space compared to the current size of the cafeteria with the construction of an addition highlighted in red in photo on the right.

Figure 27. Classroom detail of coat "cubby" area, teacher's storage closet, and workstation with sink:: original drawing on the left from 1954 compared to the current condition of a typical classroom detail in photo on the right.

Figure 28. Classroom detail of storage shelf and tack board: original drawing on the left from 1954 compared to the current condition of a typical classroom detail with a replacement whiteboard where the tack board used to be located in photo on the right.

Figure 29. Classroom detail of chalkboard: original drawing on the left from 1954 compared to the current condition of a typical classroom detail where the original chalkboard has been replaced by a whiteboard in photo on the right. 


\section{Preface}

This study was conducted for Fort Leonard Wood (FLW), under project 32645, "Architectural Survey of Pence Elementary School, Fort Leonard Wood, Missouri." Funding was provided by Military Interdepartmental Purchase Request (MIPR) \#10042772. The technical monitor for the project was Ms. Stephanie L. Nutt, FLW Cultural Resources Program Coordinator.

The work was performed by the Land and Heritage Conservation Branch (CN-C) of the Installations Division (CN), Construction Engineering Research Laboratory (CERL). Adam Smith was the CERL Project Manager and architectural historian, Sunny Adams was the lead architectural historian, and Chris J . Cochran was the assistant architectural historian. Dr. Christopher White is Chief, CN-C, and Dr. J ohn Bandy is Chief, CN. The Deputy Director of CERL is Dr. Kirankumar V. Topudurti. The Director of CERL is Dr. Ilker R. Adiguzel.

CERL is an element of the U.S. Army Engineer Research and Development Center (ERDC), U.S. Army Corps of Engineers. The Commander and Executive Director of ERDC is COL Kevin J. Wilson, and the Director is Dr. J effery P. Holland.

\section{Acknowledgements}

Special acknowledgement is given to those at FLW who assisted with this report-especially Stephanie Nutt, Cultural Resources Program Coordinator. 


\section{Unit Conversion Factors}

\begin{tabular}{|l|c|l|}
\hline Multiply & By & To Obtain \\
\hline acres & $4,046.873$ & square meters \\
\hline degrees Fahrenheit & $(\mathrm{F}-32) / 1.8$ & degrees Celsius \\
\hline feet & 0.3048 & meters \\
\hline inches & 0.0254 & meters \\
\hline miles (U.S. statute) & $1,609.347$ & meters \\
\hline square feet & 0.09290304 & square meters \\
\hline square miles & $2.589998 \mathrm{E}+06$ & square meters \\
\hline yards & 0.9144 & meters \\
\hline
\end{tabular}




\section{Introduction}

\section{Background}

Through the years, the U.S. Congress has enacted laws to preserve our national cultural heritage. The Antiquities Act of 1906 was the first major federal preservation legislation and was instrumental in securing protection for archeological resources on federal property. The benefits derived from it and subsequent legislation precipitated an expanded need for the preservation of historic cultural resources. With this growing awareness, the Congress passed the National Historic Preservation Act of 1966 (NHPA), the most sweeping cultural resources legislation to date.

The Congress created the NHPA to provide guidelines and requirements aimed at preserving tangible elements of our past, primarily through the creation of the National Register of Historic Places (NRHP). This piece of legislation (Sections 106 and 110) requires federal agencies to address their cultural resources, defined as any prehistoric or historic district, site, building, structure, or object. Section 110 requires federal agencies to inventory and evaluate their cultural resources. Section 106 requires the determination of effect of federal undertakings on properties deemed eligible or potentially eligible for the NRHP.

The U.S. Army Maneuver Support Center of Excellence (MSCoE) is located at Fort Leonard Wood (FLW), Missouri. FLW is located off of Interstate 44 , in the northern portion of the Ozarks. The installation presently contains nearly 61,895 acres of the Missouri Ozarks and is located about 120 miles southwest of St. Louis and 85 miles northeast of Springfield, Missouri (Figure 1). The cantonment occupies approximately 6,000 acres in the northeast portion of the fort (Figure 2). Ranges and impact areas occupy most of the southern half of the fort.

The post was created in December 1940 and by early J anuary 1941 the War Department designated the installation as Fort Leonard Wood. The post was named in honor of General Leonard Wood, a former Army Chief of Staff. In April 1941, FLW received its first soldiers. While initially designated an infantry division training area, FLW quickly took on an engineer training mission for World War II (WWII). 
Following the end of WWII in 1945, training ceased completely by 1946 and the post was put on the inactive list; it reopened in August 1950 for the Korean Conflict. In 1956, the installation was designated the U.S. Army Training Center-Engineer. Because of its new status as a permanent post, FLW received funds to replace the wooden WWII-era buildings with permanent brick and concrete structures (Roberts 2008).

In 1985, FLW entered yet another phase in its history. That year, the Secretary of the Army announced that the U.S. Army Engineer School (USAES) would move from Fort Belvoir, Virginia, to FLW as part of the Base Realignment and Closure (BRAC) action. In 1999, the BRAC process also closed Fort McClellan, Alabama, causing the U.S. Army Chemical School (USACS) ${ }^{1}$ and U.S. Army Military Police Corps School (USAMPS) to be transferred to FLW. FLW was concurrently redesignated the U.S. Army Maneuver Support Center and today, is an MSCOE.

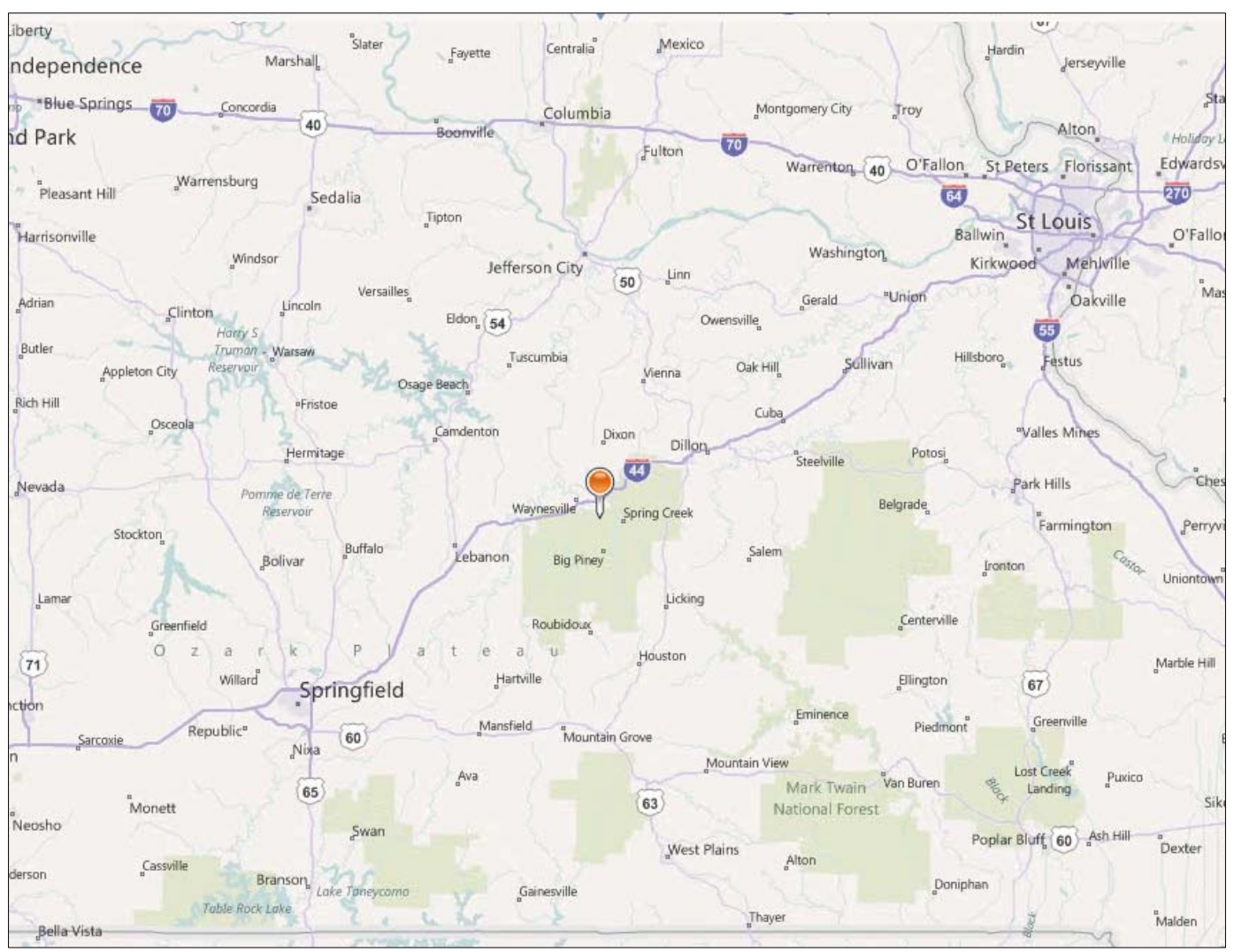

Figure 1. Location of FLW is indicated by the push-pin (Bing maps).

${ }^{1}$ Now known as the Chemical, Biological, Radiological, and Nuclear (CBRN) School. 


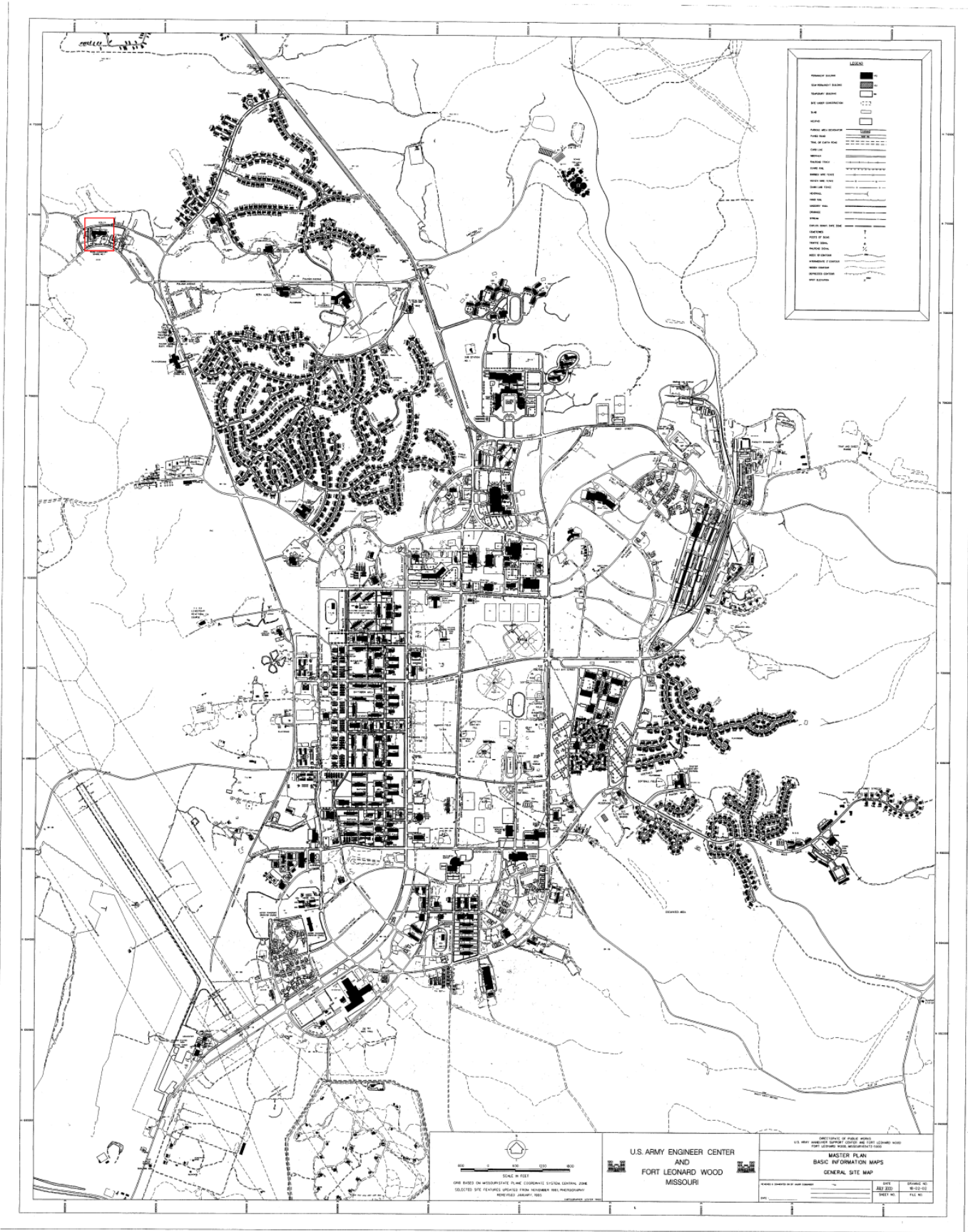

Figure 2. Map of FLW from July 2000, with Building 6824 indicated by the red box in the upper left corner (FLW Natural Resources Branch).

Per Section 110 of the NHPA, FLW must evaluate all of its buildings and structures aged 50 years and older. FLW has completed several architectural surveys for Section 110 compliance; however, Building 6824 (Pence Elementary School) was not included in any of the previous reports. The Engineer Research and Development Center, Construction Engineering 
Research Laboratory (ERDC-CERL) subsequently was tasked to complete a full assessment of Building 6824.

\section{Objectives}

At the request of FLW, this study was to determine the historical significance of the 1954 Building 6824, Pence Elementary School, at FLW, Missouri. This work was to specifically assess the school for eligibility to the NRHP. For a property to qualify for the NRHP, it must meet at least one of the National Register Criteria for Evaluation, must be significantly associated with an important historic context, and must retain sufficient integrity to convey its significance.

\section{Approach}

Per Section 110 of the NHPA, FLW needs to evaluate all of its buildings and structures that are 50 years of age and older; Building 6824 falls within that category by having a construction date of 1954. The building was not included in previous surveys conducted by ERDC-CERL; at the time those times, Building 6824 was leased to Waynesville R-VI School District.

This work was accomplished in the following steps:

\section{Archival research}

Archival research involves two primary tasks: (1) the initial literature review, and (2) the identification and location of primary research materials.

\section{Literature review}

The research team used an existing architectural survey for a general understanding of the history of FLW. Secondary literature determined the history of Department of Defense (DoD) school construction and their significance in the history of the United States and of FLW. Sources included a variety of published and unpublished material, notably: the Fort Leonard Wood Integrated Cultural Resources Management Plan FY 2002 to 2006 (Edging 2003), Fort Leonard Wood Building Survey 1941 to 1956 (Smith et al. 2003), FLW Rolling Pin Barracks and Associated Buildings Context and Inventory (Smith et al. 2007), and Fort Leonard Wood Cantonment Landscape Context, Inventory, and Management (Tooker et al. 2007). 


\section{Primary research materials}

The research team located primary research materials and additional secondary sources to establish a strategy to best use these resources. Research material for the school was gathered during the site visit to FLW. The material included maps and a file folder full of information from the Waynesville School District R-VI.

\section{Site visit}

In April 2011, members of the research team conducted one site visit to FLW to survey the school and conduct research. During this visit, researchers collected archival information, such as maps and historic photographs from Cultural Resources. Researchers conducted site reconnaissance on foot using photography, sketches, and note taking. After the site visit, the research team made preliminary determinations of historic significance.

\section{Analysis}

After completing the initial research, the team analyzed the gathered resources and information. Historic maps and photographs were examined and compared to current day conditions. DoD school history was researched and was synthesized with information taken from a previous report on the history and architecture of DoD Schools. The team used those resources to determine the structure's integrity, and then, based on historic context and themes, determined its historic significance.

\section{Evaluation}

The evaluation of structures followed the guidelines in National Register Bulletin \#15, How to Apply the National Register Criteria for Evaluation, and National Register Bulletin \#16, How to Complete the National Register Registration Form. In addition, the survey followed the DoD guidance, Guidelines for Identifying and Evaluating Historic Military Landscapes (Loechl et al. 2009).

\section{Mode of technology transfer}

This report will be made accessible through the World Wide Web (WWW) at URL: http:// libweb.wes.army.mil/uhtbin/ hyperion/CERL-TR-11-25.pdf 


\section{Historic Context of Department of Defense Schools}

This chapter contributes to the evaluation of the significance of Building 6824 (Pence Elementary School) at FLW by situating it within the general historic context of DoD school design and construction.

\section{General history}

In the early 1800s, the one-room schoolhouse was typical (Figure 3). One room was necessary because one teacher was responsible for all students. Students would recite their assignments for the teacher while the rest of class listened. Students were promoted when the teacher felt that they were ready. In this way, younger students often learned what they needed to know from older students (Graves 1993, 22).

During the first half of the 19th century, urban schools often had a different arrangement. The Lancastrian School System (named after educator J oseph Lancaster) allowed many more students to be taught by one teacher than in the one-room schoolhouse (Figure 4). The teacher would intensively teach 50 students, who would then act as leaders and supervise 10 students each. This arrangement allowed a single teacher to be in charge of 500 students (ibid.). While such schools were gone by 1840 , they served as an example of how group instruction could function with few resources.

Beginning in the 1840s, students were separated by grade with a teacher for each grade. The curriculum expanded beyond just reading and writing to include history, grammar, and composition. The classroom organization was essentially the same as it previously was, but now several classrooms were combined into one building. Drastic improvements in lighting, heating, toilet facilities, and fire safety created much nicer environments for the students (Graves 1993, 25). Still, schools were basically stacks of classrooms with an applied Gothic, Greek Revival, or Victorian facade to create a cohesive building (Figure 5). 


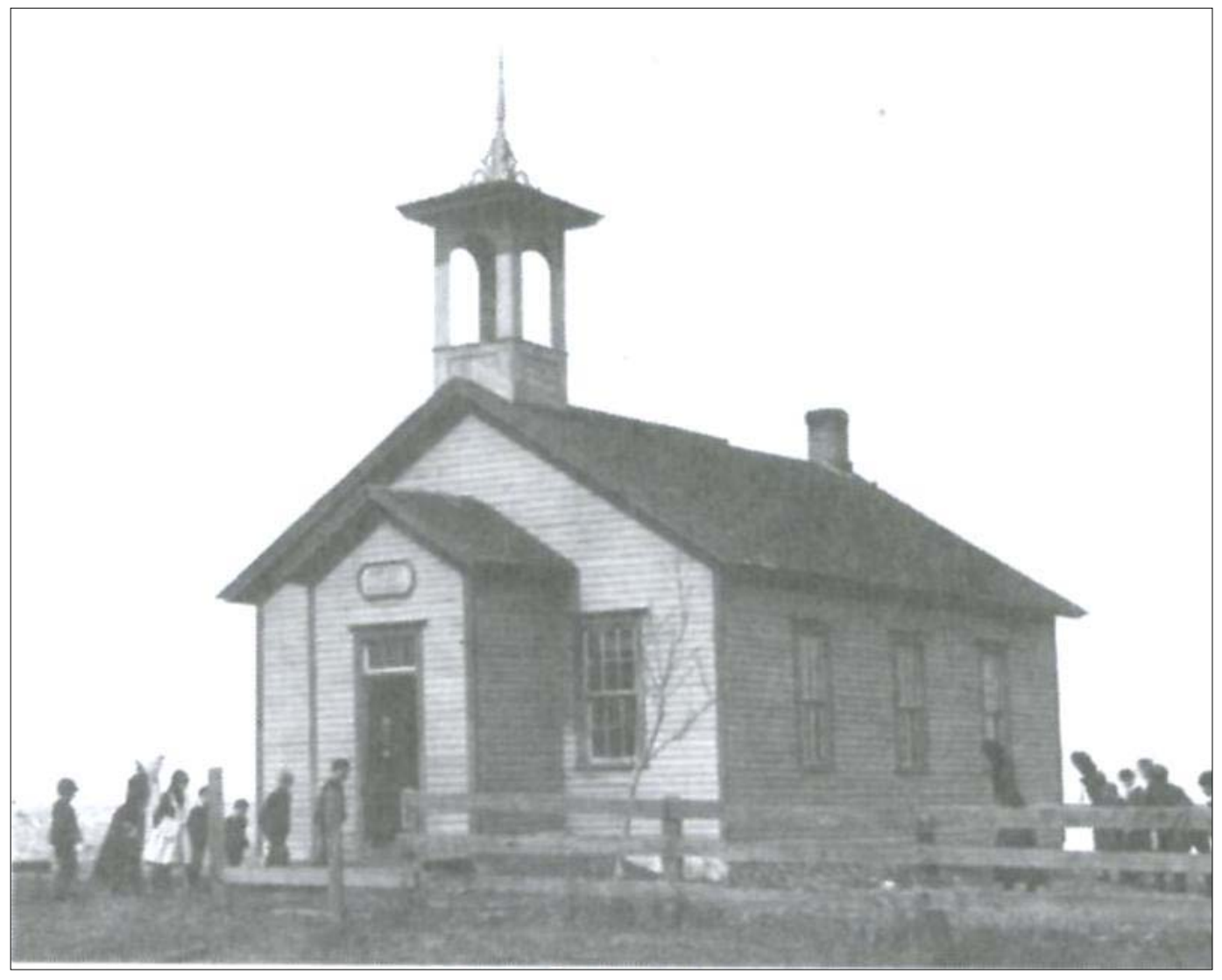

Figure 3. One room schoolhouse, c. 1870 (Tanner, 4).

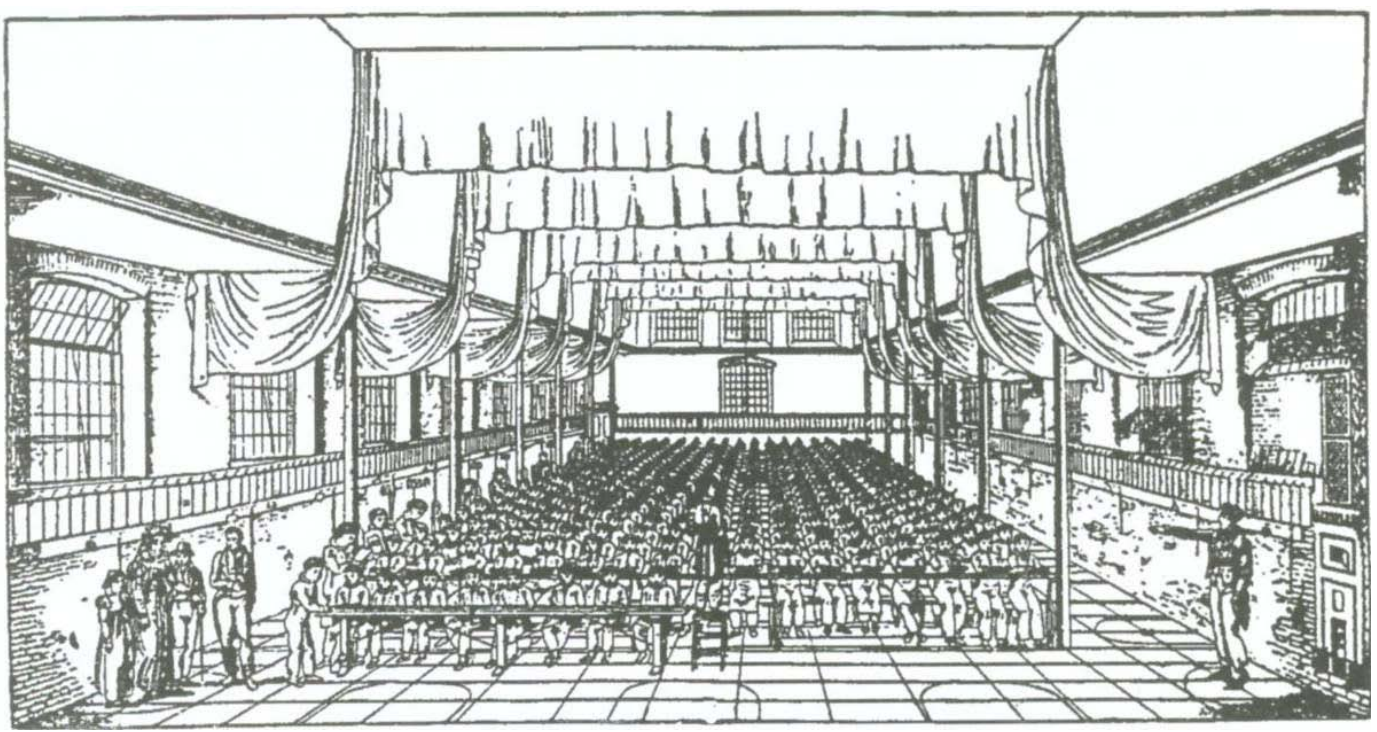

Figure 4. Lancastrian school (Graves, 23). 


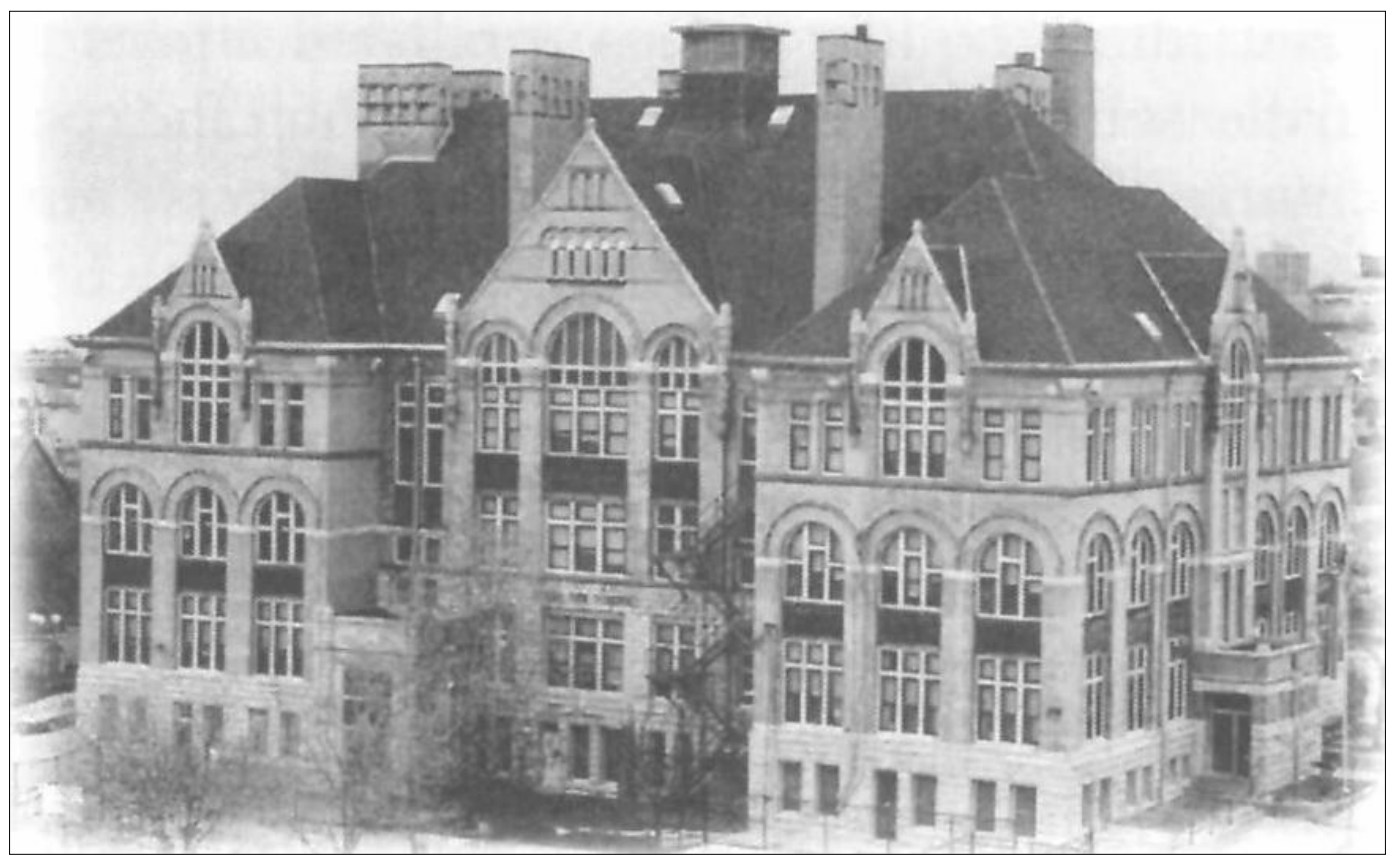

Figure 5. Romanesque Revival style school in Milwaukee, c. 1889 (Tanner, 7).

\section{Post-World War II schools}

The year 1950 seems to be the turning point for school architecture. By this time, contemporary architecture had won the battle against traditional architecture. People began to realize that schools should be designed to meet the needs of students.

\section{Contemporary architecture of 1950 s}

In contemporary architecture of this period, schools would no longer look like colonial mansions, but rather, they would have a unique identity to show the world that they were indeed a school and not to be confused with any other building type. Theories such as "form follows function" and "form should express function" were being applied to new school buildings. The students were being considered during the design process, with a corresponding realization that single-story flat-roof structures were more amicable to children due to their smaller overall size and lower ceiling heights (Caudill 1954, 16-17).

New materials also were being introduced, such as glass and metal window walls with brick or concrete walls (Figure 6). Natural lighting and ventilation were being considered; strip windows were being used for classrooms to let in more natural lighting (Figure 7). 
For many communities, the 1950s were an opportune time period to improve their schools. Following a lack of construction during the Great Depression and WW II eras and an increase in population of school-aged children, there was a demand for new schools. Sadly, schools in this time period often were built in a hurry and as inexpensively as possible, and this led to poorly insulated roofs and walls, poor lighting and ventilation, and the need for extensive yearly maintenance (Brubaker 1998, 15).

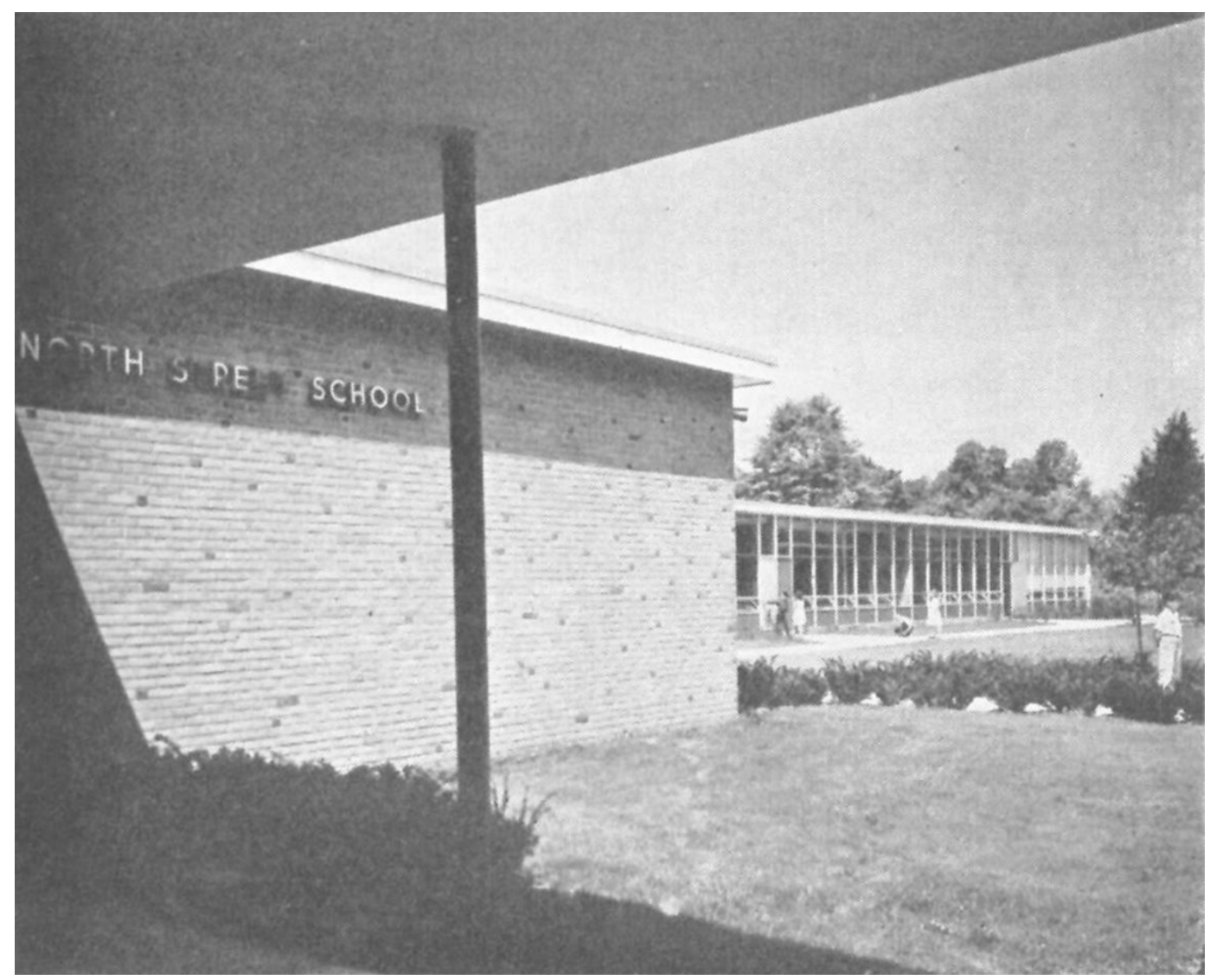

Figure 6. A 1950s school design featuring a combination of brick with metal and glass (Two Connecticut, 155).

Crow Island Elementary School in Winnetka, Illinois, was a design catalyst for school buildings built after the 1950s. Designed by architects Perkins, Wheeler, and Will in collaboration with Eliel and Eero Saarinen and constructed in 1940, this school was the first to separate from the traditional Victorian style of school buildings (Graves 1993, 33). The progressive design proved that no longer did a school have to conform to being essentially a large cube with massive scale, formal architecture, and rigid organization of classrooms. Crow Island School created an informal plan that allowed students to feel more comfortable, with each wing having its own 
identity (Figure 8). The school was designed to meet the needs and wants of the child, not what adults think a child should be like (Tanner 2006, 13).

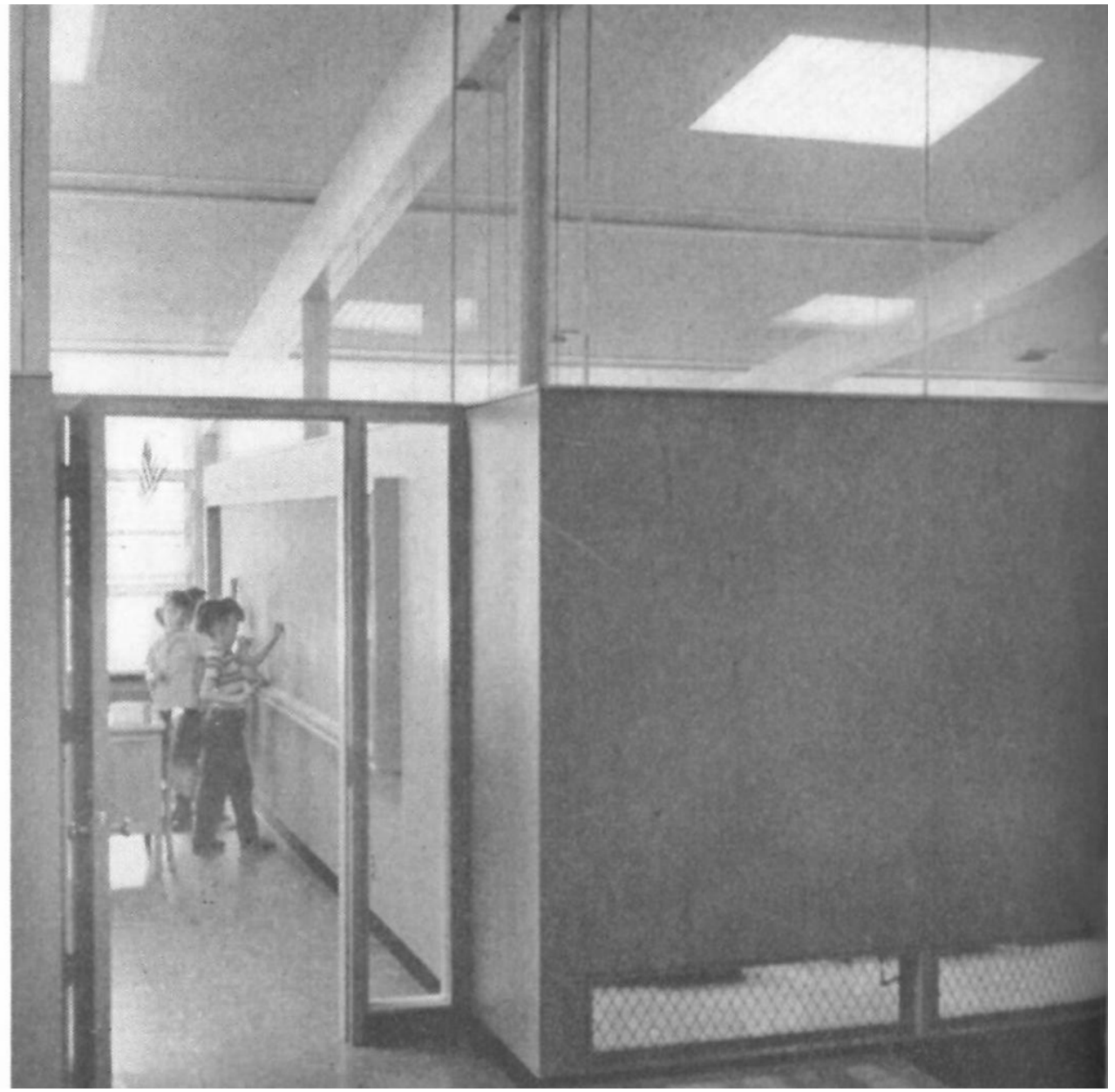

Figure 7. Clerestory windows allow more natural light through the building (Orientation, 166). 


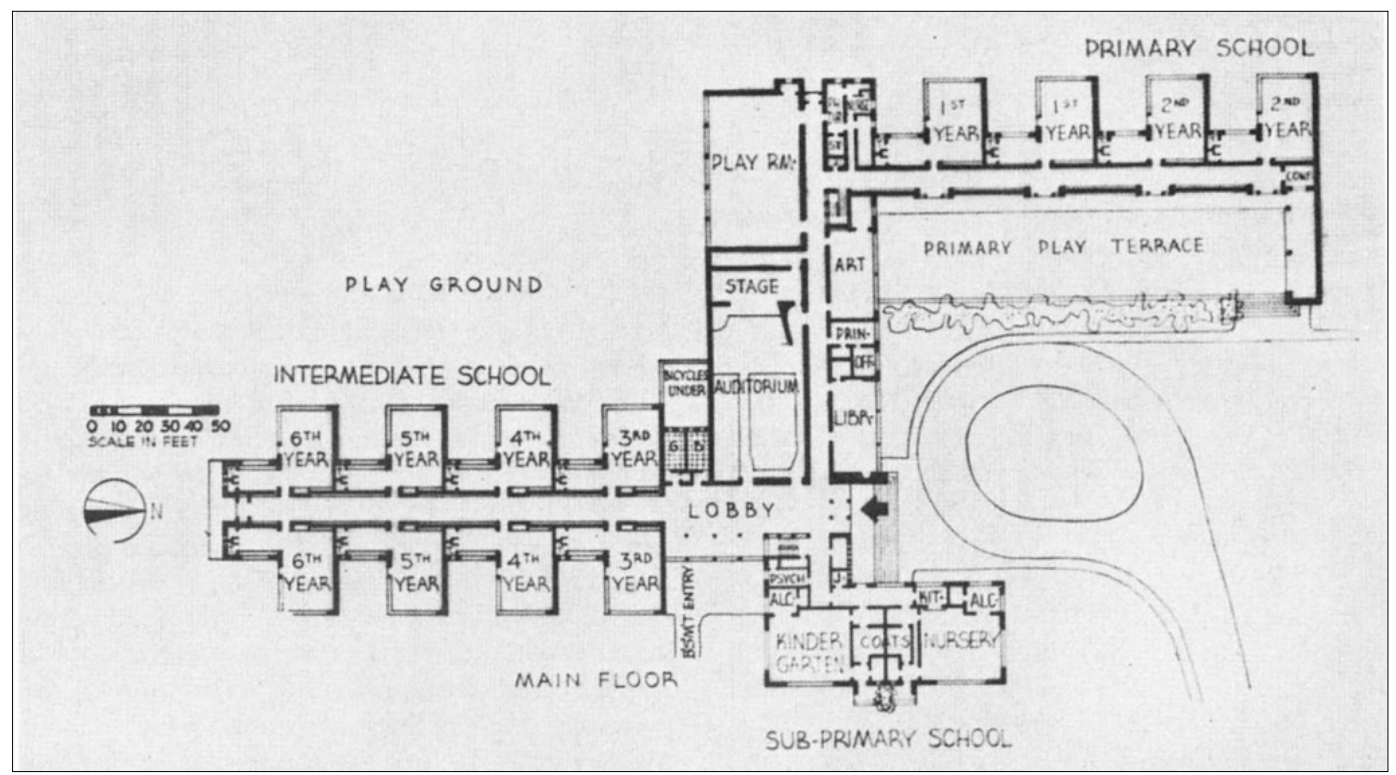

Figure 8. Crow Island School plan (Christ-Janer, 95).

The Crow Island School was built entirely on one floor, with a clock tower near the middle (Figure 9). Classrooms created fingers off main corridors that led to centralized shared spaces like the auditorium and library. Lots of windows allowed a tremendous amount of light into the space and help the students feel more relaxed. Nine-foot ceilings brought the classroom down to a scale that schoolchildren are comfortable with (compared to 12foot ceilings common in Victorian designs). Direct access to the outdoors from each classroom was also an amenity not seen in previous schools (Figure 10). Common brick was used on both the interior and exterior of the building, but exterior redwood trim and interior Ponderosa pine trim created a warm and inviting feeling for the students. Three fireplaces throughout the building also helped to reinforce the idea that students should feel at home in the learning environment (Graves. 1993, p.33-35).

Crow Island added another classroom wing about 15 years after the original building was completed. Many aspects of the original building were duplicated, but many issues that arose over that first 15 years were also addressed. For instance, larger overhangs addressed sky glare. Heating units were put under the windows to create more even heating, although it took away space that the sills created for displaying various projects. Taller chalkboards were installed to give greater surface area, but their height took away from the available space to pin up papers above the board. Classrooms remained L-shaped, but the $L$ was reconfigured to make it more open and user friendly ("Crow Island" 1955, 130-137). 


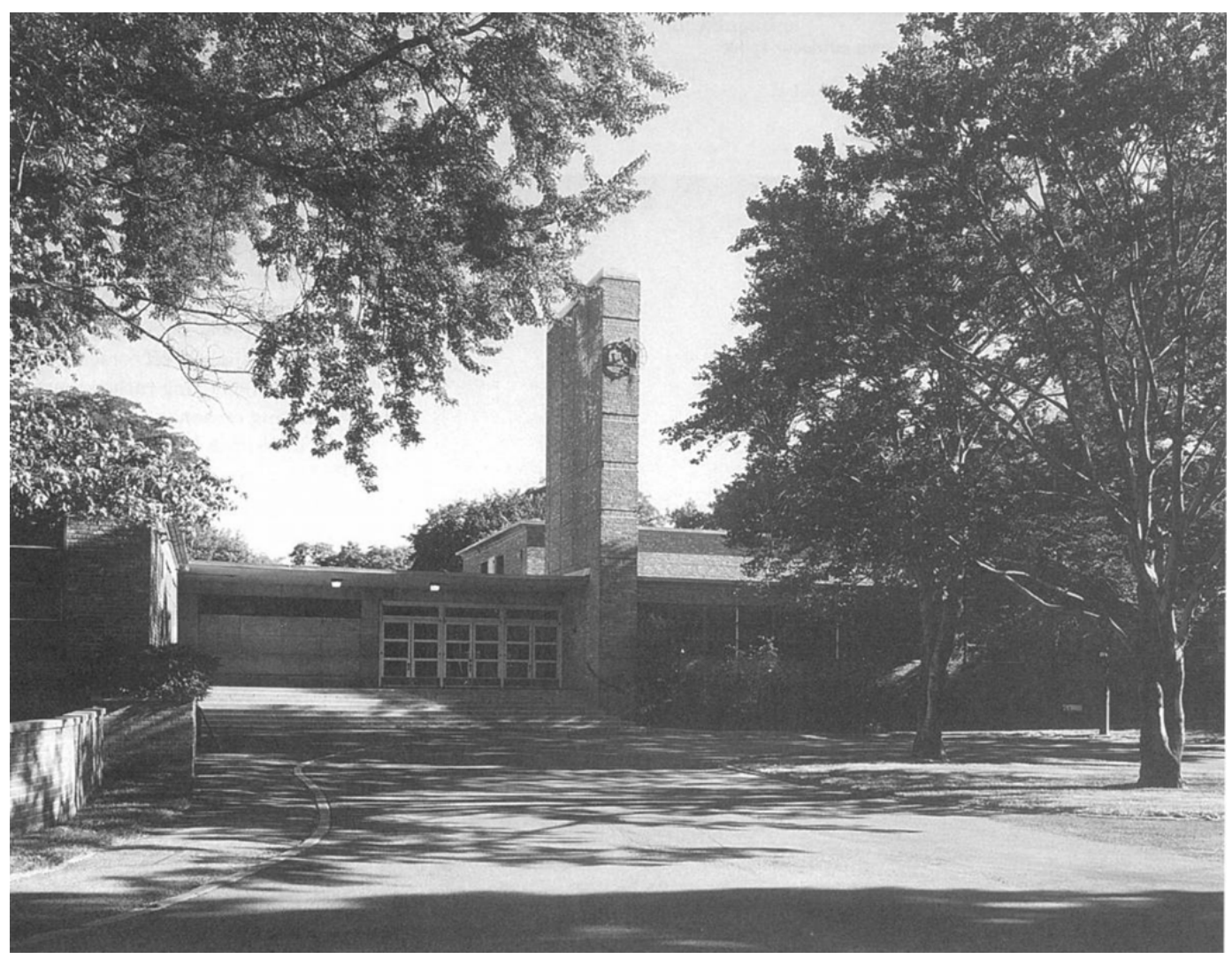

Figure 9. A clock tower divides wings of Crow Island School (Brubaker 1998, 11).

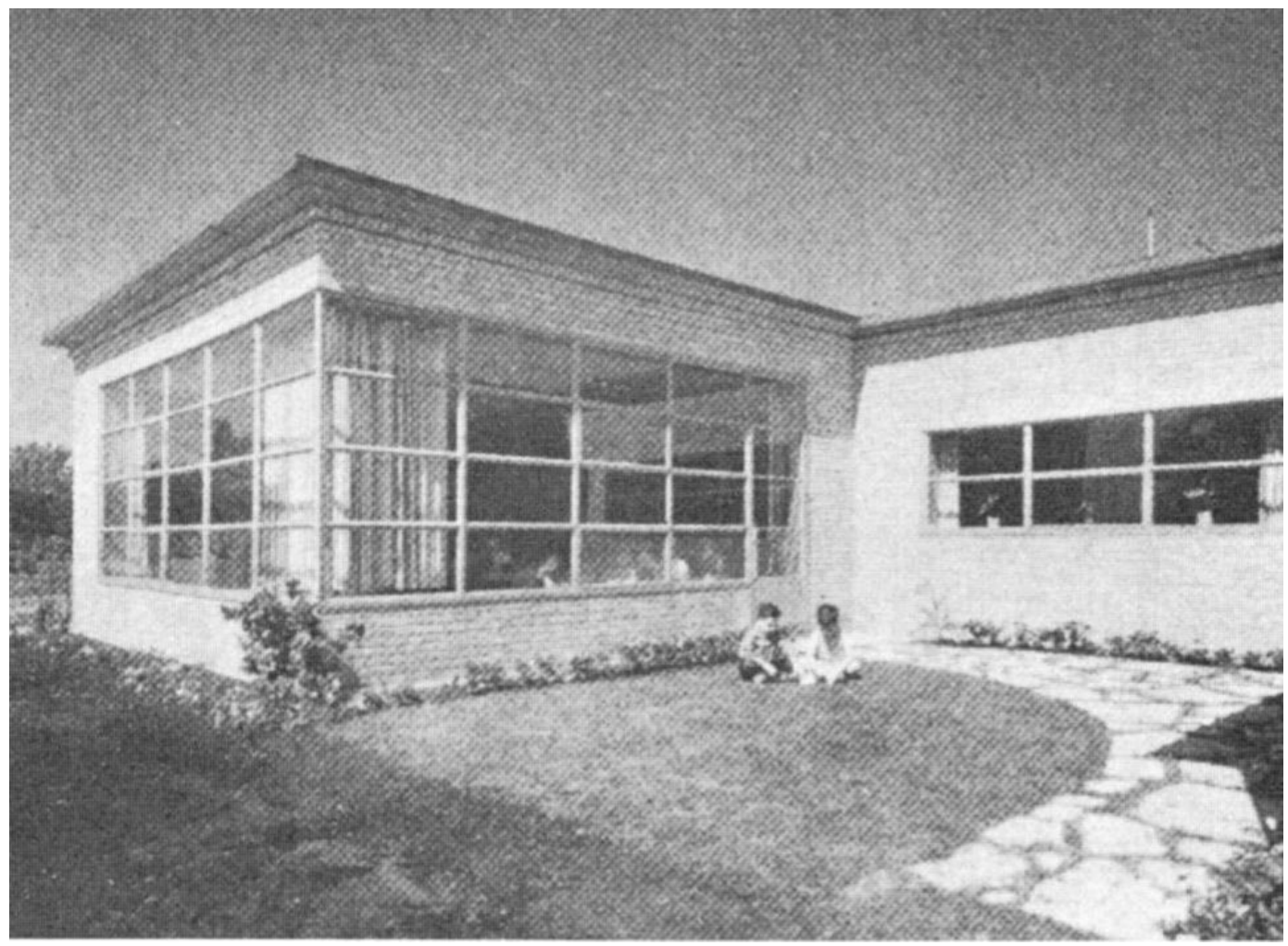

Figure 10. Each classroom at Crow Island has direct access to the outdoors (Christ-Janer, 98). 


\section{Campus plan design}

Also in the 1950s and the 1960s, there were a few examples of schools that were built under the campus plan. Similar to the finger plan of Crow Island, the campus plan featured central, shared services that were accessed by main corridors connected to classrooms. It was different, however, in that instead of having the "fingers" projecting from the corridors, there were circular classroom pods (Figure 11). Architect Warren Ashley designed the Old Saybrook High School in Saybrook, Connecticut, with a looped corridor to connect the classroom pods to the main offices and cafeteria (Figure 12; New 1955, 147).

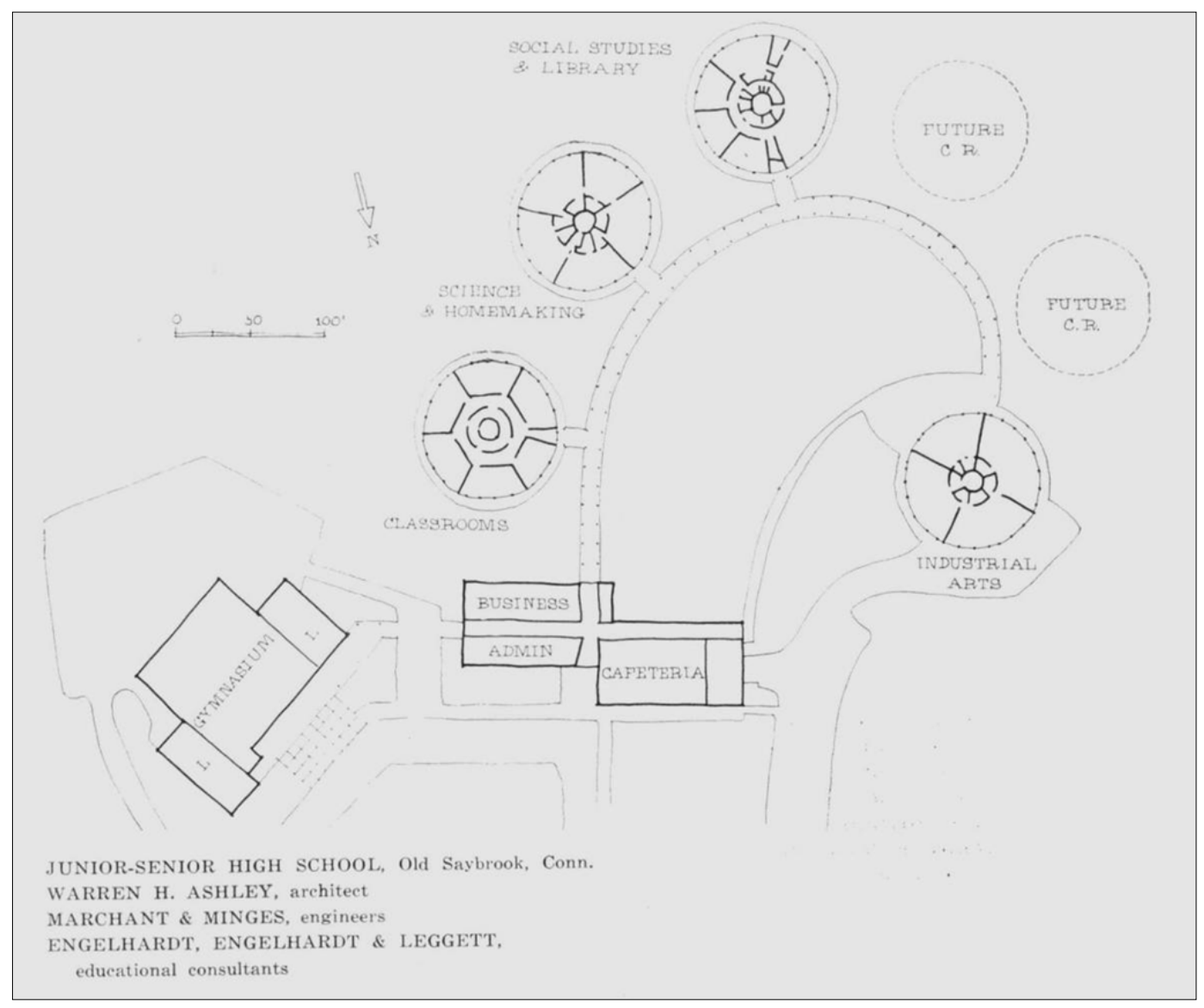

Figure 11. Old Saybrook High School, site plan of pod design (New Kind of High School, 147). 


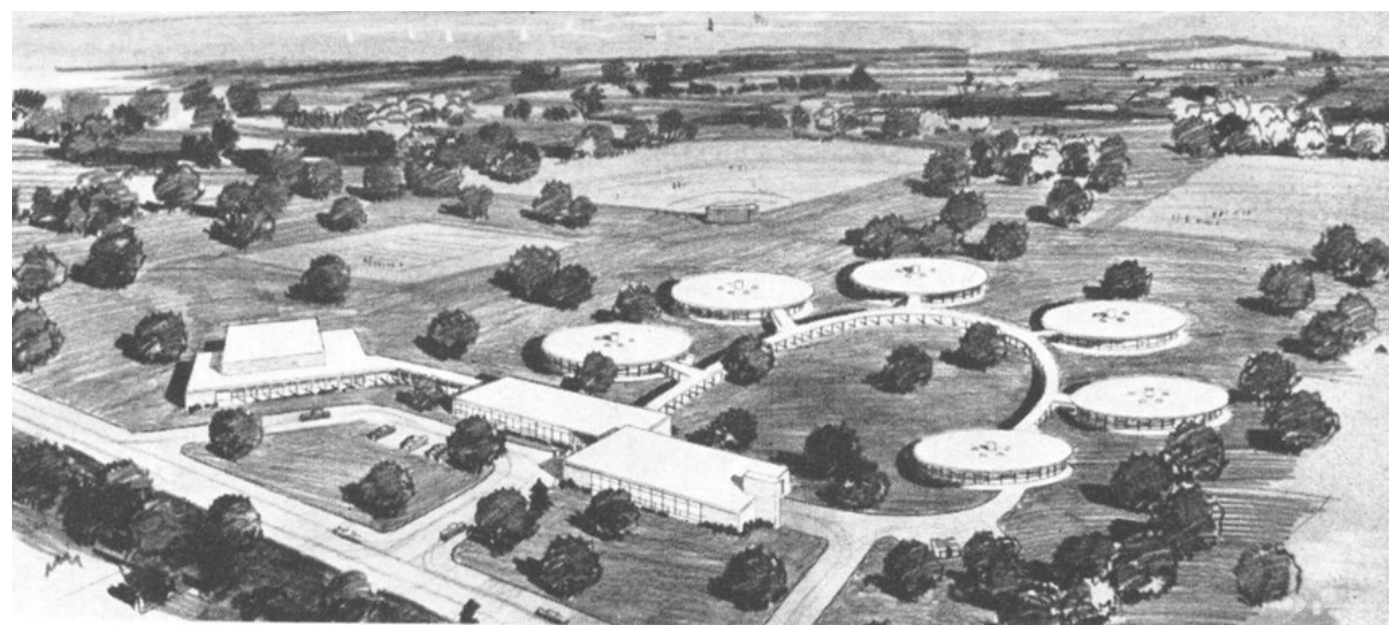

Figure 12. Old Saybrook High School, birdseye view of pod design (New, 147).

Another example of the campus plan is the Montgomery Central High School in Cunningham, Tennessee. This design by Shaver and Company architects (Figure 13) allowed the classroom clusters to completely surround an administrative complex (Figure 14). The gymnasium building also was connected to the administrative complex and surrounded by special-purpose classrooms such as home economics and woodshop (Sanders n.d.).

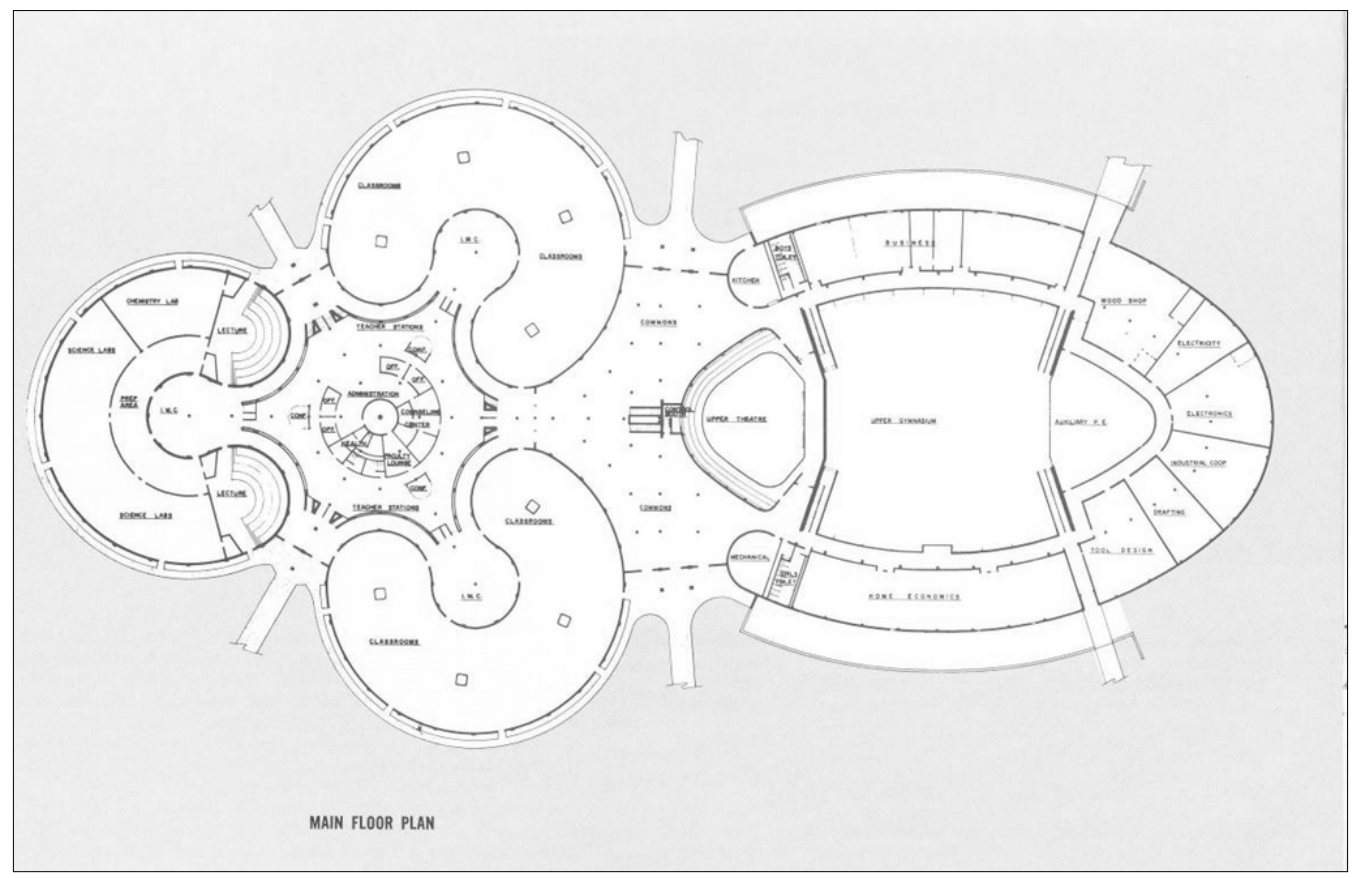

Figure 13. Montgomery Central High School, Cunningham, Tennessee, floor plan (Sanders). 


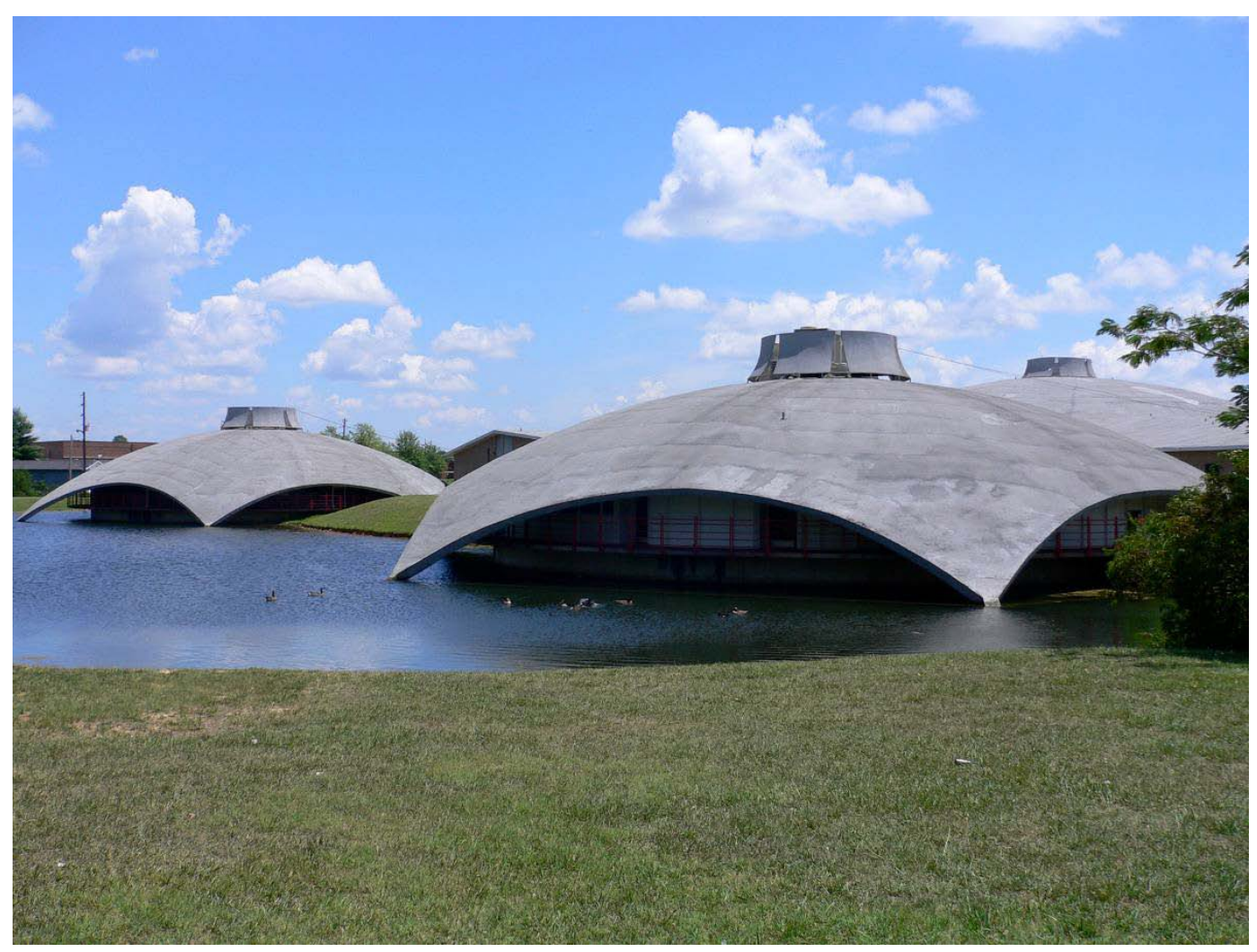

Figure 14. Montgomery Central High School, Cunningham, Tennessee (Sanders).

\section{Open-plan designs}

During the 1960s, the open-plan design influenced the layout of thousands of schools. The open plan made use of folding or moveable walls, to gain flexible space. An open plan allowed the space to adapt to the school's changing needs and allowed for large, open space for team teaching along with small group and individual instruction. Perkins \& Will were leading proponents of this theory with their design for The Disney School in Chicago (Figure 15). This idea didn't last very long as teachers complained of noise and visual distractions (Figure 16; Tanner 2006, 13). Research studies have been done on open plan schools and the results have been inconclusive and highly controversial. Many open plan schools have been refitted with permanent wall partitions (Brubaker 1998, 20). 


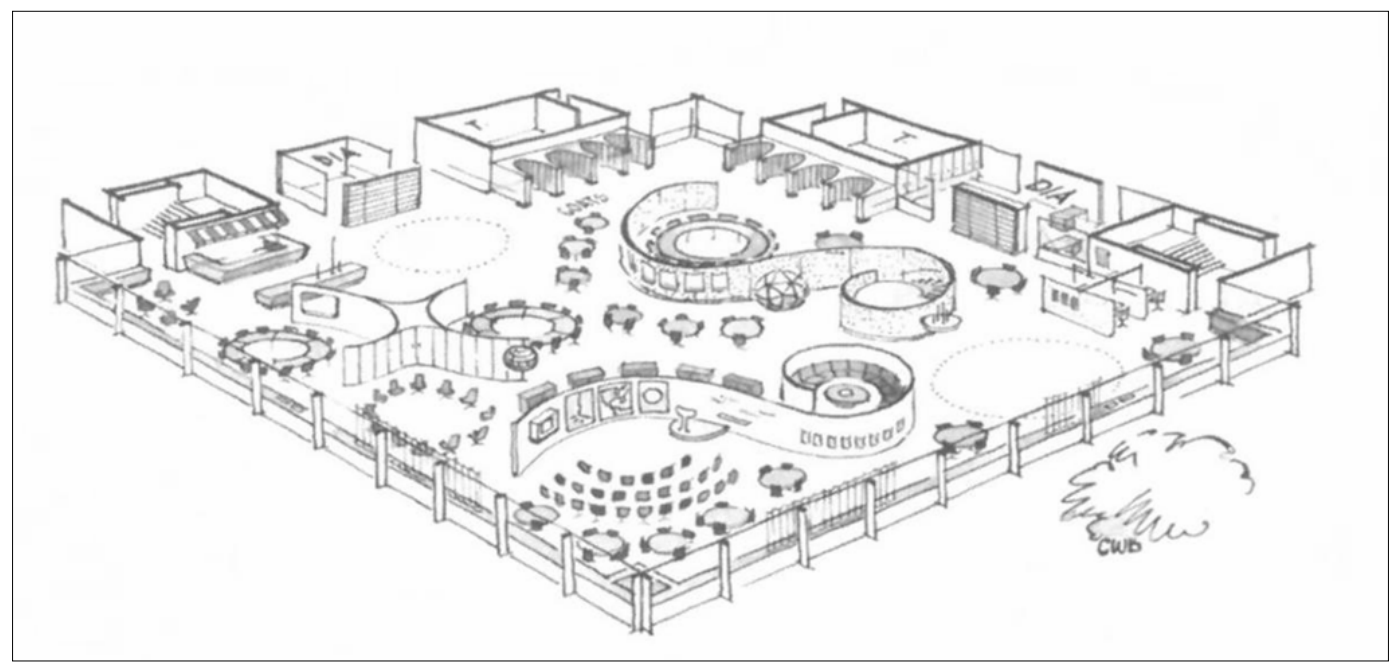

Figure 15. Disney School site plan (Tanner 2006, 16).

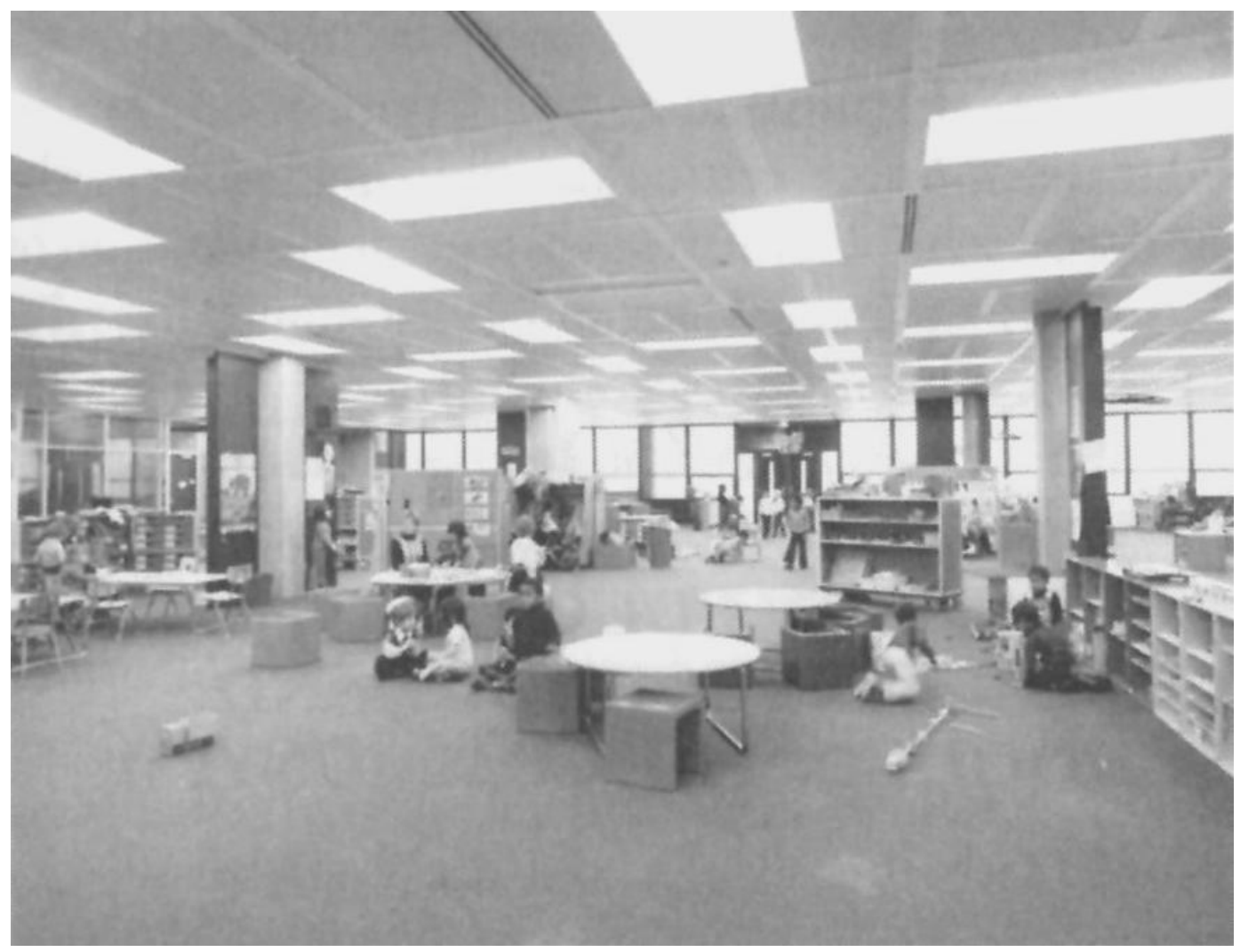

Figure 16. Disney School open classroom (Tanner 2006, 17).

\section{Other design concepts}

After the 1960s, the benefits of natural lighting and ventilation were forgotten due to the introduction of air conditioning and fluorescent lighting in schools. Many designs reduced windows to vertical ribbons barely a foot wide, reasoning that views to the outside were distracting. 
The 1980s saw a boom in enrollment, especially in high schools. In the 1980s, school designs responded to the philosophy of outcome-based education. In the beginning of the $21^{\text {st }}$ century, the focus now is learnercentered classrooms. Children are techno-savvy, and the classroom needs flexibility (Rydeen 2008).

\section{First school built under PL 81-874}

Lincoln Elementary, located at Fort Campbell, Kentucky and built in 1951, was the first school built under Public Law (PL) 81-874 (Figure 17). PL 81874 was an extension of the 1941 federal emergency measure (Lanham Act) and was referred to as the Impact Aid Program. PL 81-874 was passed by Congress in 1950 to assist local school districts with construction and costs of local public education that is impacted by federal defense efforts. School districts eligible for this funding included those where: (1) children lived on federal property and their parents worked on federal property; (2) children either lived on federal property or their parents worked on federal property; and (3) children whose parents came into the district as a result of federal contracts with private firms. Lincoln Elementary, primarily constructed of brick, exemplifies the style of the early 1950s school-a onestory structure with a flat roof (Figure 18).

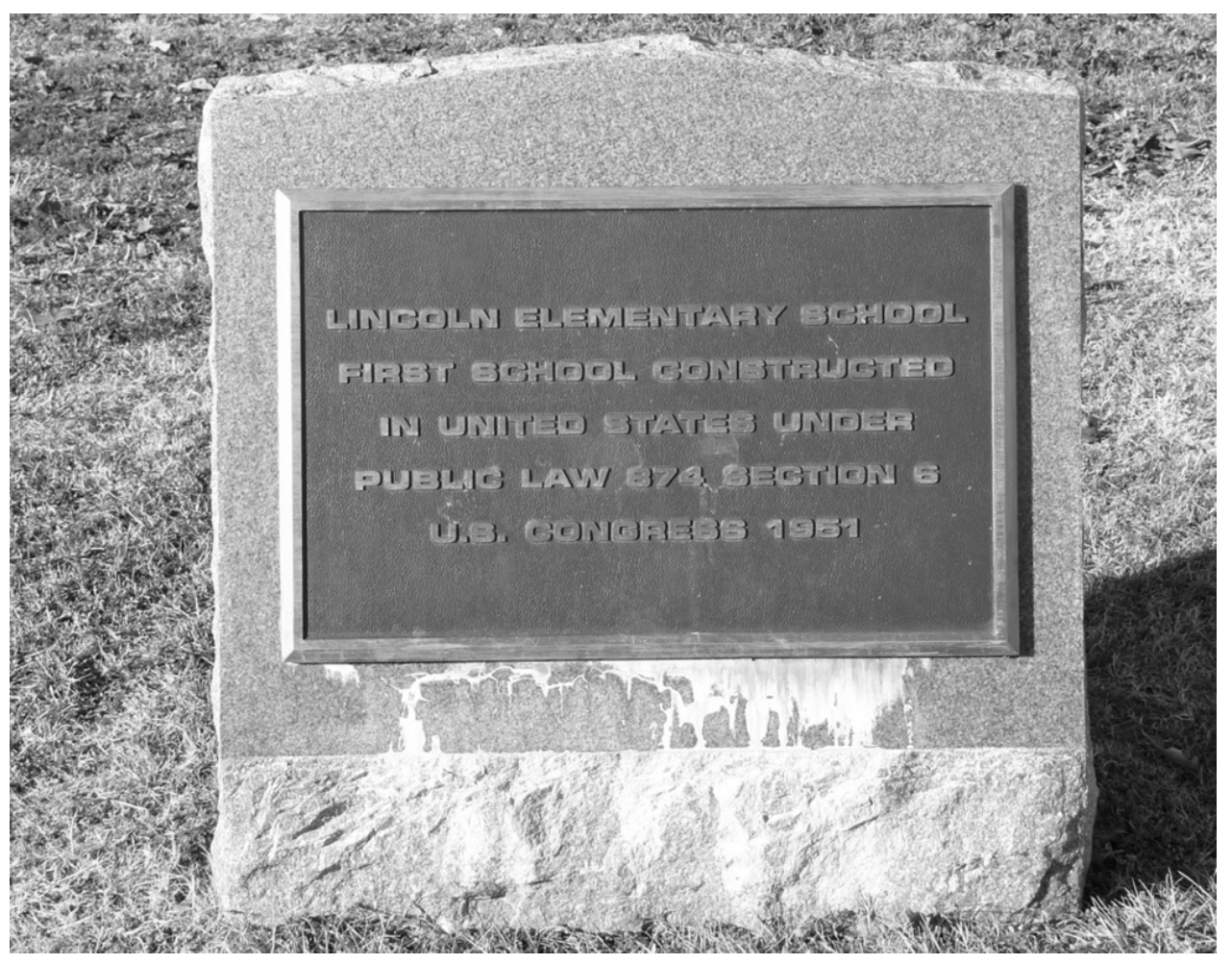

Figure 17. Lincoln Elementary and Public Law 81-874 (ERDC-CERL). 


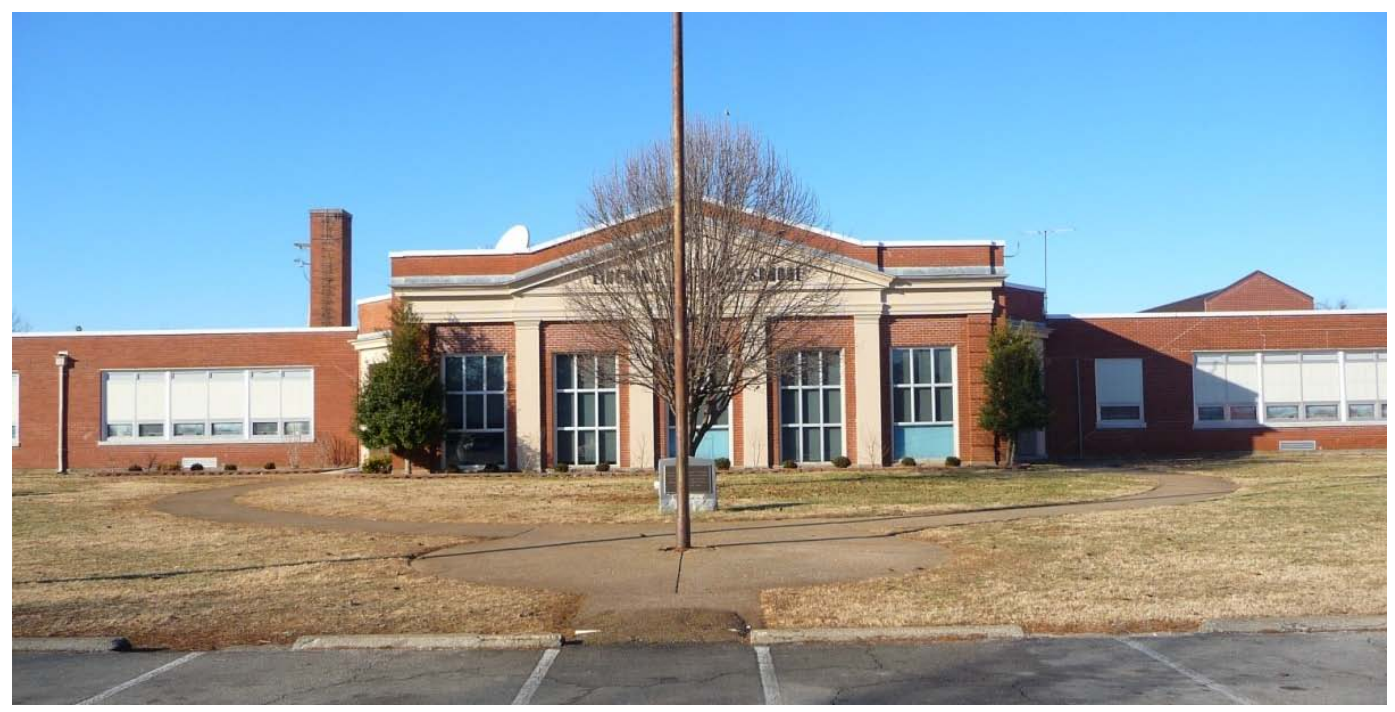

Figure 18. Lincoln Elementary School, Fort Campbell, Kentucky (ERDC-CERL).

\section{Fort Leonard Wood schools}

Constructed in 1912, Rolling Heath School (Figure 18) is currently the oldest standing building on FLW. During FLW's pre-installation days, Rolling Heath served as the area elementary school until 1940 for students through eighth grade. The school was restored between 1993 and 1995 through a grant from the DoD Legacy Resource Management Program. Currently, the school is a natural and cultural resources outreach and education center for the Directorate of Public Works (DPW), Natural Resources Branch.

Like the rest of the country, FLW saw a boost in school construction during the 1950s due to the very large baby boomer generation entering the school system. Thayer Elementary School, Pick Elementary School, Wood Elementary School, Partridge Elementary School, and Pence Elementary School were all constructed at FLW during the 1950s according to FLW Real Property records. 


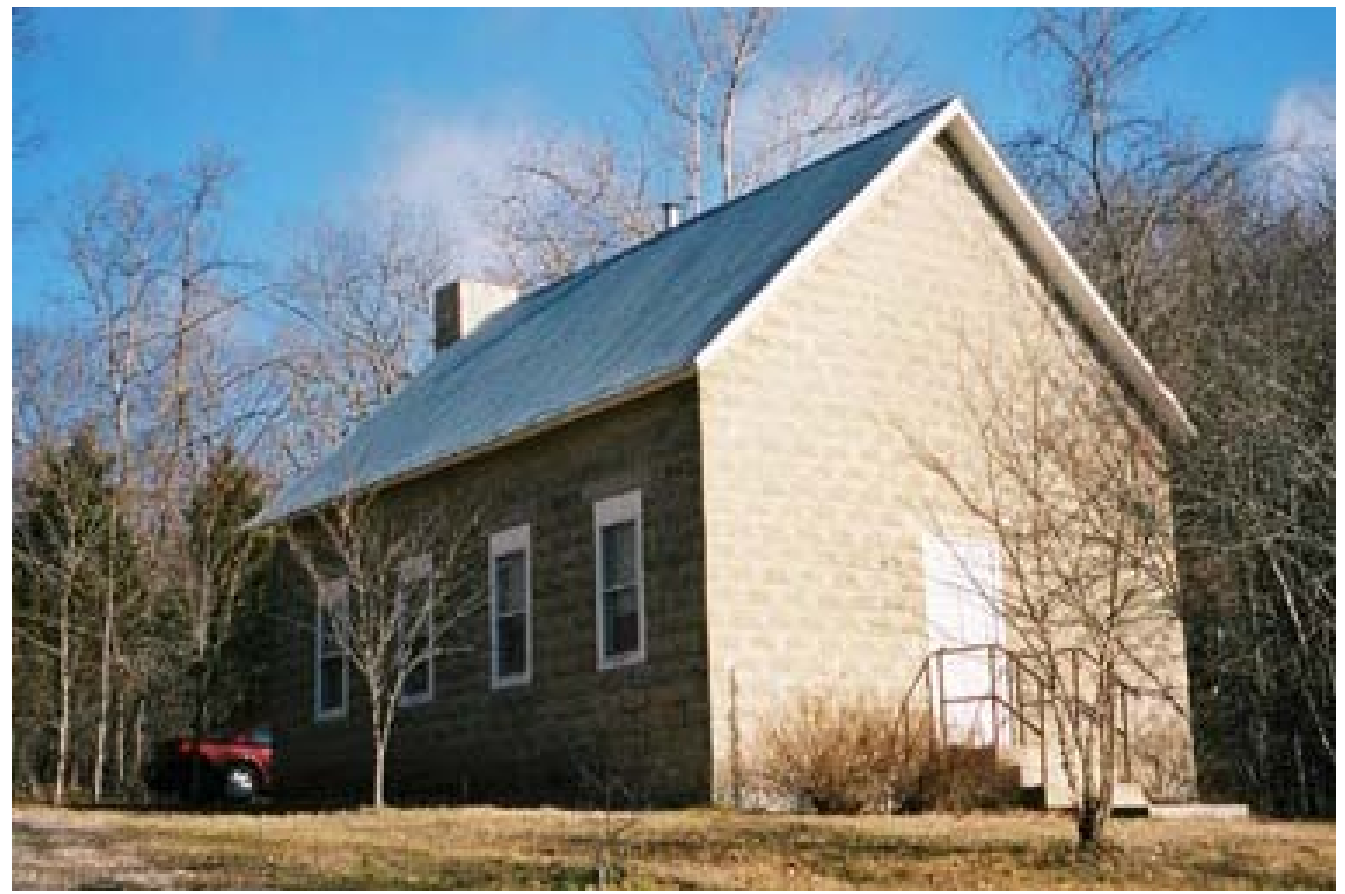

Figure 19. Rolling Heath School, constructed in 1912, is currently the oldest building located at Fort Leonard Wood (ERDC-CERL2004). 


\section{Survey Results}

The identification of historically significant properties is achieved through evaluation of their position within the larger historic context. According to the NRHP, historic contexts are defined as "...the patterns, themes, or trends in history by which a specific occurrence, property, or site is understood and its meaning (and ultimately its significance) within prehistory or history is made clear (NPS 1991). A historic property is determined significant or not significant by applying standardized National Register Criteria for Evaluation within the property's historical context.

Several previous surveys have been completed for FLW. These reports defined a historic context, and the purpose of these reports was to identify, inventory, and evaluate the historic resources on site. Building 6824 (Pence Elementary School) was not included in a previous report because the school was leased to Waynesville R-VI School District and was not being operated by FLW at that time (see "Previous studies" section below). Since then, the building lease has been terminated, and the building has been transferred back to the Army.

\section{Applying criteria for evaluation}

The National Register Criteria for Evaluation describe how properties and districts are significant for their association with important events (Criterion $\mathrm{A}$ ) or persons (Criterion $\mathrm{B}$ ), for their importance in design or construction (Criterion C), or for their information potential (Criterion D). The following is a brief description of the four NRHP Criteria for Evaluation, as excerpted from NPS Bulletin \#15 (NPS 1991, 2): 2 , 3

Criterion A (event) - "associated with events that have made a significant contribution to the broad patterns of our history; or"

Criterion B (person) - "associated with the lives of persons significant in our past; or"

Criterion C (design/ construction) - "embody the distinctive characteristics of a type, period, or method of construction, or that represent the work of a master, or that possess high artistic values, or

\footnotetext{
2 NPS Bulletin \#15 reproduces the Criteria for Evaluation and notes that they also are found in the Code of Federal Regulations, Title 36, Part 60.

3 Descriptive wording in parentheses has been added by the report authors.
} 
that represents a significant and distinguishable entity whose components may lack individual distinction; or"

Criterion D (information potential) - "yielded, or is likely to yield, information important in prehistory or history."

\section{Aspects of integrity}

In addition to possessing historical significance, in order to be eligible to the NRHP properties must also retain sufficient physical integrity of features to convey its significance (NPS 1991, 44).

Historic properties both retain integrity and convey their significance, or they do not. Within the concept of integrity, the National Register criteria recognize seven aspects or qualities that, in various combinations, define integrity. To retain historic integrity, a property will always possess sever$\mathrm{al}$, and usually most, of the aspects. The retention of specific aspects of integrity is paramount for a property to convey its significance. Determining which of these aspects are most important to a particular property requires knowing why, where, and when the property is significant.

Districts and individual resources are considered to be significant if they possess a majority of the following Seven Aspects of Integrity (NPS 1991, 44- 45):

1. Location is the place where the historic property was constructed or the place where the historic event occurred.

2. Design is the combination of elements that create the form, plan, space, structure, and style of a property. It results from conscious decisions made during the original conception and planning of a property (or its significant alteration) and applies to activities as diverse as community planning, engineering, architecture, and landscape architecture. Design includes such elements as organization of space, proportion, scale, technology, ornamentation, and materials.

3. Setting is the physical environment of a historic property. Setting refers to the character of the place in which the property played its historical role. It involves how, not just where, the property is situated and its relationship to surrounding features and open space.

4. Materials are the physical elements that were combined or deposited during a particular period of time and in a particular pattern or configuration to form a historic property. 
5. Workmanship is the physical evidence of the crafts of a particular culture or people during any given period in history or prehistory.

6. Feeling is a property's expression of the aesthetic or historic sense of a particular time period.

7. Association is the direct link between an important historic event or person and a historic property.

\section{Previous studies}

Pence Elementary School was not surveyed as part of the Fort Leonard Wood Building Survey 1941 to 1956 (Smith et al. 2003), even though the construction date of the elementary school, 1954, falls within the time period for others structures surveyed. The reason the building was not surveyed is because it was not owned/ operated by FLW at that time, but rather was leased to Waynesville R-VI School District.

The Secretary of the Army granted to the Commissioner of Education (Department of Health, Education, and Welfare) 2.30 acres on FLW property under Permit No. 84-15, which was effective August 5, 1953. The Secretary of the Army, acting for and on behalf of the United States of America, as Secretary, did grant Lease No. DACA41-1-99-501 to the Waynesville R-VI School District, for the construction, operation, and maintenance of the school facilities (Pence Elementary School) ${ }^{4}$

The following is a brief history of ownership and use of the building as extracted from various letters and documentation provided to the ERDCCERL research team from the Waynesville School District 5 :

- Department of H ealth, Education, and Welfare Termination of Permit

The permit granted by the Commissioner of E ducation, Department of Health, Education, and W elfare, hereinafter called the Commissioner, on N ovember 20, 1956, to the W aynesville Reorganized School District N o. 6, W aynesville, M issouri, hereinafter called the A gency, to use and occupy for school purposes the school facilities designated as Project N o. M 0-56-C-FED-1A6, on Fort Leonard W ood M ilitary Reservation, M issouri, provides that "This permit shall remain in effect until terminated by mutual agreement of the parties or revoked by the Commissioner." The Commissioner declares permit terminated as of A ugust 29, 1957 (see A ppendix B).

\footnotetext{
4 Pence Elementary School was built by the Waynesville R-VI School District, not by FLW. FLW leased the property, not the school building, to the school district and the school district had the school constructed on the property.

${ }^{5}$ Although the school was constructed in 1953, the file provided by the school district starts with 1956.
} 
- Permit for School Purposes on F ort Leonard Wood M ilitary Reservation Waynesville, Missouri

The W aynesville Reorganized School District No. 6, W aynesville, M issouri, a local education agency, is herby granted a permit beginning on the 29th day of A ugust, 1957, by the Commissioner of Education, D epartment of Health, E ducation, and W elfare to use and occupy for school purposes, pursuant to Public Laws 815 and 874, 81st Congress, as amended and the permit dated A pril 6, 1954, to the Commissioner from the Secretary of the A rmy, all school buildings and other facilities located on the land in the State of M issouri, County of Pulaski, which is described at the end hereof, together with all equipment, furnishings, and appurtenances installed therein or located thereon on the date of this permit or thereafter provided by the Commissioner, all of which are hereinafter collectively referred to as the Property.

This permit shall remain in effect until terminated by mutual agreement of the parties or revoked by the Commissioner.

A) Termination of the permit for the use of the land granted to the Commissioner by the Secretary of the A rmy under date of A pril 6, 1954 (see A ppendix C).

- L Letter dated 22 May 1981

Reference is made to USOE permit for use of Real Property by a Federal A gency Permit No. M 0-52-C-FED-1A, which grants to the Department of the A rmy (Permittee) by the Commissioner of Education (Permitter) the use of Pence Elementary School at FLW, M issouri, for A rmy Child Care Center, for 5-year term, beginning 1 J uly 1980 and ending 30 J une 1985 (see A ppendix D).

- Letter dated April 26, 1994

Subjects: 1. Return of Pence School Building

The W aynesville School District once again requests the return of the Pence School $B$ uilding for use by the district. The B oard real izes the A rmy is constructing a child care facility which was discussed with us more than 10 years ago. A ccording to a conversation with General Ballard, that facility should be completed in mid-year 1995.

1. Purpose: To provide information on ownership and return of control of the building being occupied by Pence Child Development Center. ${ }^{6}$

2. Discussion.

a. The land under Pence has been under Department of the A rmy lease to the Commissioner of Education since 1953. The building was constructed by the R-V I school district and is owned by the district. The same principle applies to the other 6 school buildings on post.

b. In 1980, the installation requested use of the building as a CDC and was issued a use permit in that year. The permit was renewed over the course of the intervening years until June of 1990.

c. In M arch 1990, the school district requested return of the building (based on anticipated construction of the new CDC effective 1 J uly 1991). The occupation permit has not been renewed and we are currently occupying the building under sufferance of the school district.

d. The school district plans to re-occupy the building as a school housing general and expanded special education missions upon completion of the new CDC in 1995 (A ppendix E).

${ }^{6}$ Author's note: later referred to in abbreviated form as "CDC." 
- November 15, 1994 letter from Waynesville R-VI School District

During the decade of the 80 s, many specific improvements were made in all the buildings we operate on FLW. At this time, Pence School leased to the A rmy for a Pre-School child care facility. It appears that with the completion of a new child facility for the FLW community, this school district will reacquire Pence building.

- Pursuant to the Resolution of the W aynesville R-VI School Districted dated M ay 18 , 1998, and December 20, 1999, to obtain ownership of the Pence Elementary School located within FLW , M issouri, and in accordance with section 8008 (b) of the Elementary and Secondary Education A ct of 1965, formal request is hereby made for the transfer of the school facility from the U nited States of A merica, U.S. D epartment of Education to the W aynesville R-VI School District (see A ppendix F).

- Permit Termination Agreement signed and dated 2001

for D epartment of Education Schools

L ocated on F ort Leonard Wood

Pulaski County, M issouri

Is made by and between the Secretary of A rmy (Permittor) and the Department of Education (Permittee) effective upon the date of execution by both parties.

W hereas: The Secretary of the A rmy granted seven separate permits to the Department of Education to use and occupy, for school purposes, seven separate parcels of land on the FLW M ilitary Installation, M issouri, between 5 A ugust 1953 and 1 A pril 1962; and

Whereas: The Department of Education in accordance with 20 U.S.C. Section 7708, has proposed to terminate the seven existing permits located on the FLW M ilitary Installation, M issouri, and transfer all capital improvements to the W aynesville R-VI School District by individual "quitclaim deed" over a period of time (see A ppendix G).

- According to Resolution W aynesville R-V 1 B oard of Education Pence Elementary School in J anuary 2011, it was stated "to terminate and rescind the ground lease on the Pence Elementary School on Fort L eonard W ood and in the quitclaim by the W aynesville R-V 1 School district to the appropriate governmental entity of the U nited States. The quitclaim deed granted by the school district will include language that the building is transferred in its "as-is" condition, the School District makes no warranties as to the condition of the building, and assumes no liability of any type after the transfer, including for the existence of materials such as friable and non-friable asbestos contained in the transferred building."

- A letter dated February 2011 sent on behalf of the W aynesville R-V 1 School District; office of the Superintendent stated that "The Pence School building located on Fort Leonard W ood has provided the School District and many on-base families with years of service. However, the usefulness of the Pence School building to the School District has ended. B ecause of its age and structural obsolescence, the building premises can no longer serve the School District's needs. Therefore, the School Board requests that the ground lease dated $M$ ay 1,2006 , and any amendments or additions thereto be terminated by written mutual agreement. Additionally, the School District requests that the A rmy accept title to the building premises. Finally, it is requested that the A rmy assume the cost of demolition of the building.

Furthermore an e-mail dated J anuary 4, 2011, requested verification that the school building was not characterized or registered as a historical structure by the Missouri Office of Historical Preservation. ${ }^{7}$ A website that

\footnotetext{
7 In an e-mail dated January 4, 2011 and addressed to Dr. Jon Oetinger, Assistant Superintendant of
} 
provides a registry listing of the designated "historical" buildings in Pulaski County was accessed; it was determined that the Pence School building was not included in that list of historical buildings located in that county.

\section{Final determinations of eligibility}

The following sections detail this study's findings regarding the historical significance of the 1954 Pence Elementary School, Building 6824 at FLW, Missouri.

\section{Finding for Criterion A - Event}

Building 6824, Pence Elementary School, is not associated with any particular event that is significant in the history of the overall Cold War period or in the history of FLW. The building was constructed to meet the growing needs of the school-age child living on post.

\section{Finding for Criterion B - Person}

There is no significant person associated with the school.

\section{Finding for Criterion C - Design/Construction}

According to the drawing documentation provided by FLW, Dan R. Sandford and Sons Architects was a firm with offices in Springfield and Kansas City, Missouri, that designed the elementary school in 1954. However, the research team could not locate any additional information about the designers. An analysis by the research team reveals that the construction and the design of this school are not unique to school building. It is of permanent materials such as concrete block walls clad with brick veneer. The rectangular layout of the building allows the classrooms and support rooms to be located off a central corridor. The original windows were fivepane steel awning windows that have been replaced with anodized bronze aluminum one-over-one windows and the original steel, three-light doors 
with sidelights and transoms have been replaced with anodized bronze aluminum and glass doors with sidelights and transoms (Figure 20Figure 29). For a complete explanation of the original design intent and subsequent modifications, please refer to the Inventory Form in Chapter 4.
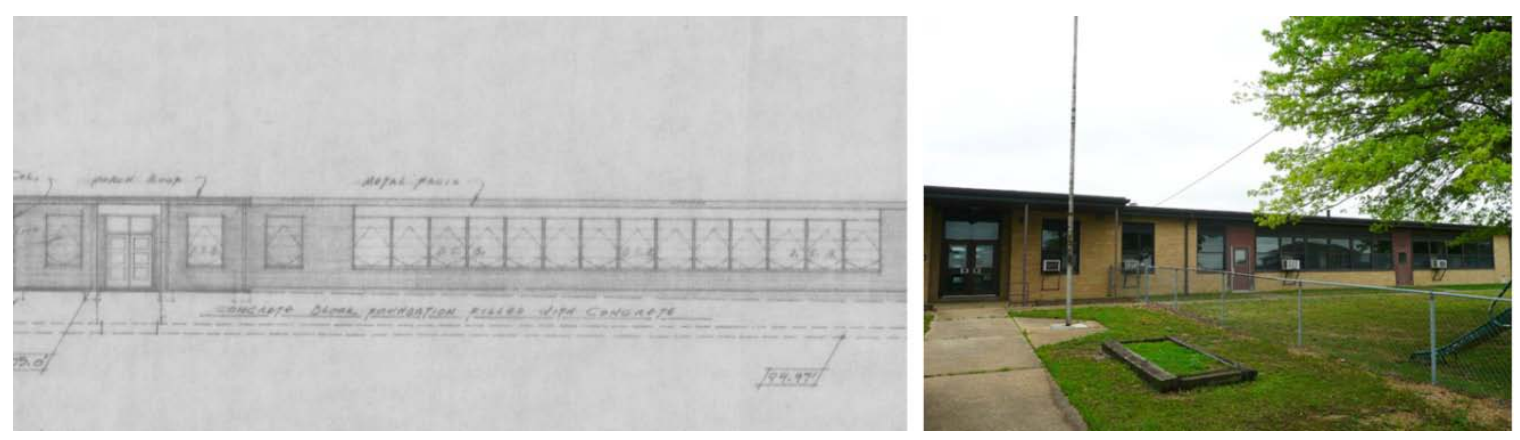

Figure 20. North elevation with main entrance and wall of windows; original drawing on the left from 1954 with origial five-pane awning windows, compared to the current replacement doors, sidelights, transom, and metal double-hung windows in photo on the right.
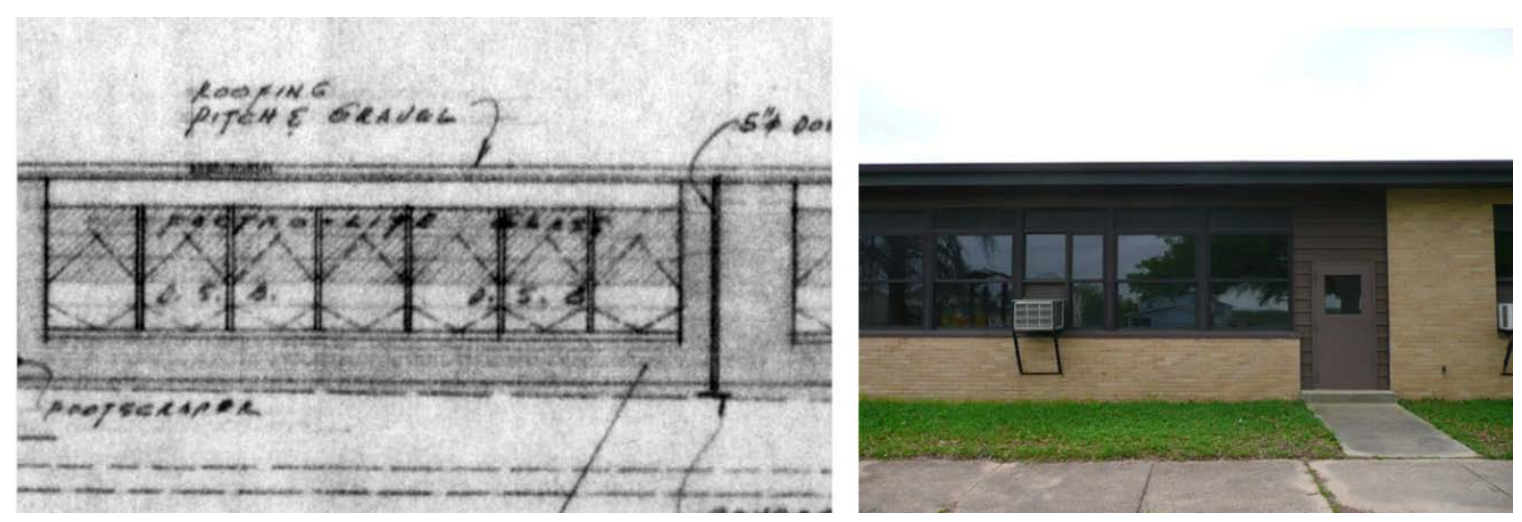

Figure 21. Window comparison: original drawing on the left from 1954, showing five-pane awning type windows compared with photo on the right, showing current replacement metal double-hung windows and a newer door opening filled with a metal door and metal siding . 

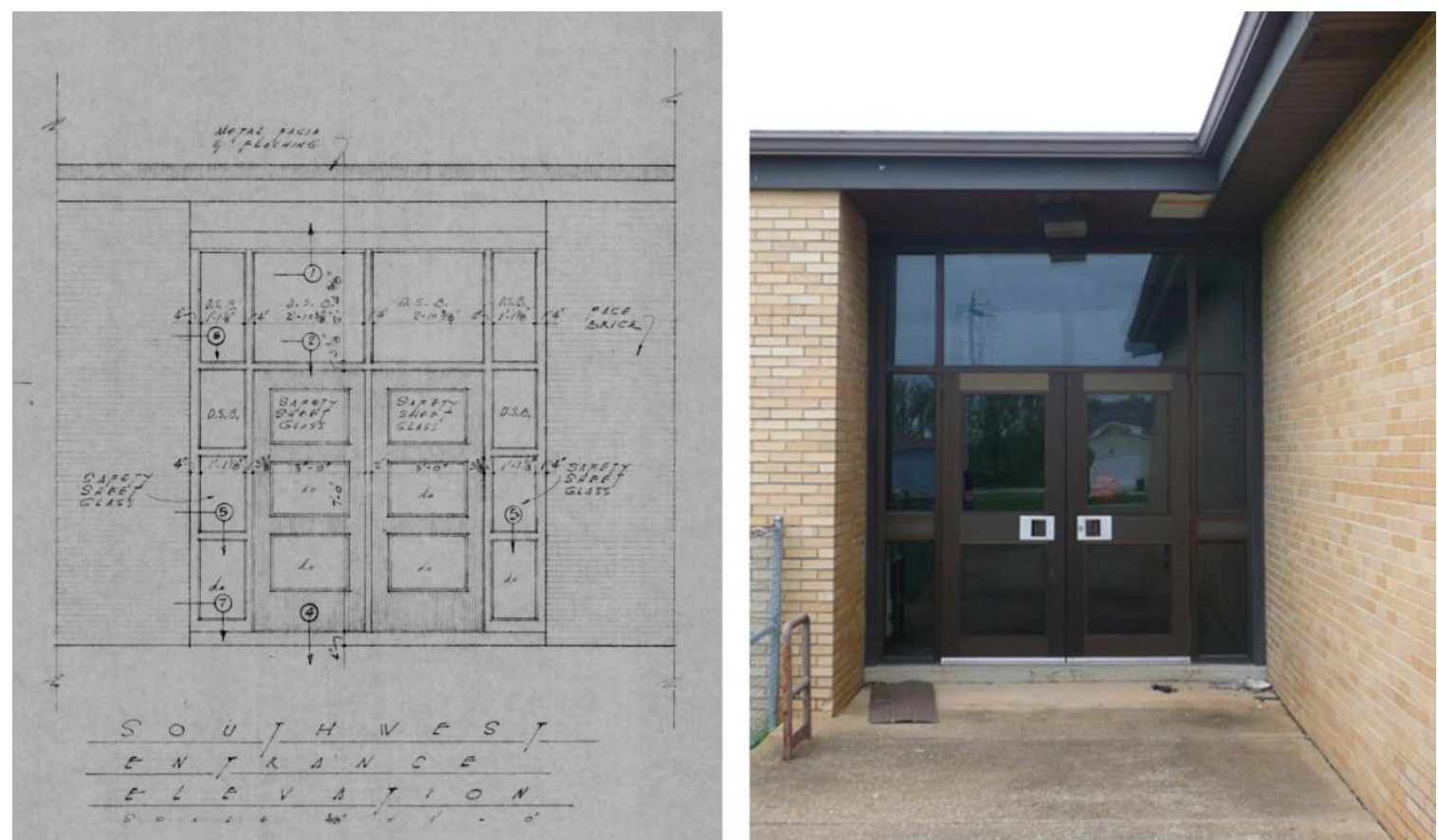

Figure 22. Southwest entrance elevation: original drawing on the left from 1954, compared to the current replacement doors, sidelights, and transom in photo on the right.
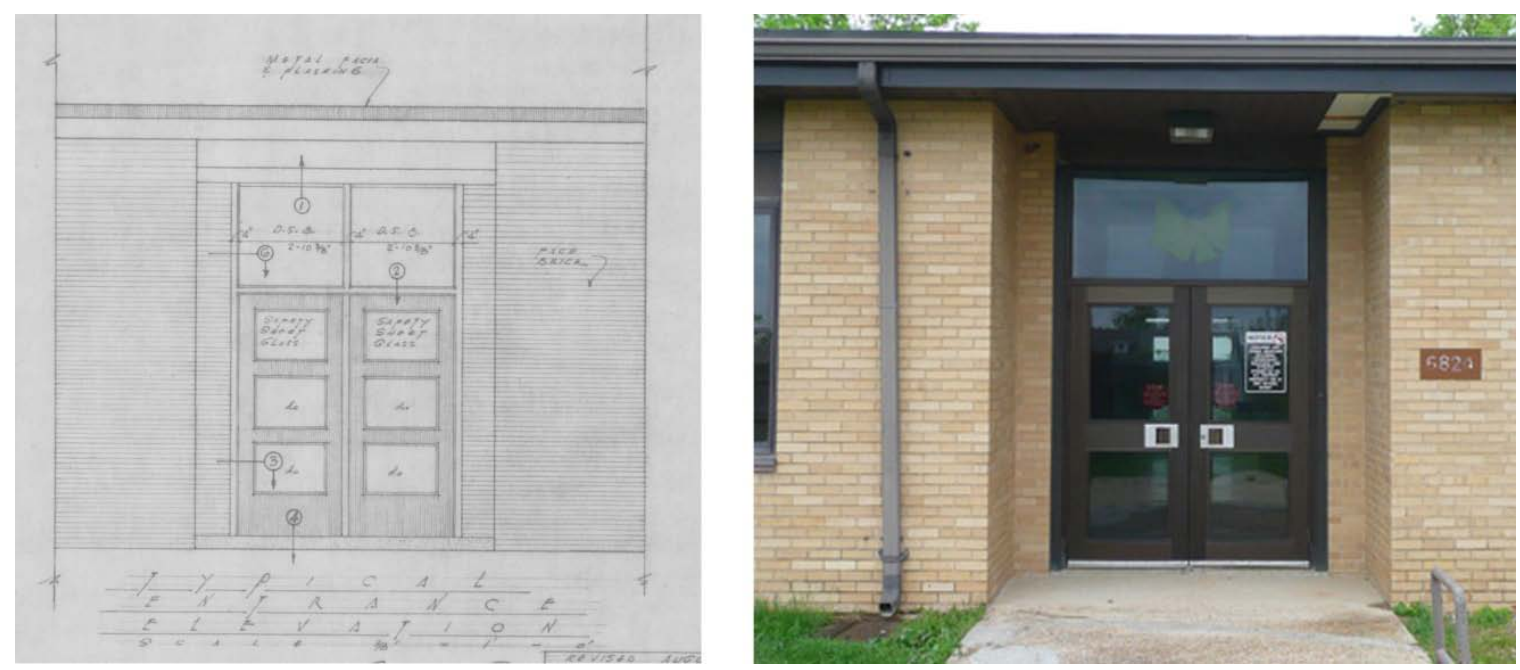

Figure 23. Entrance on south elevation: original drawing on the left from 1954, compared to the current replacement doors and transom in photo on the right. 

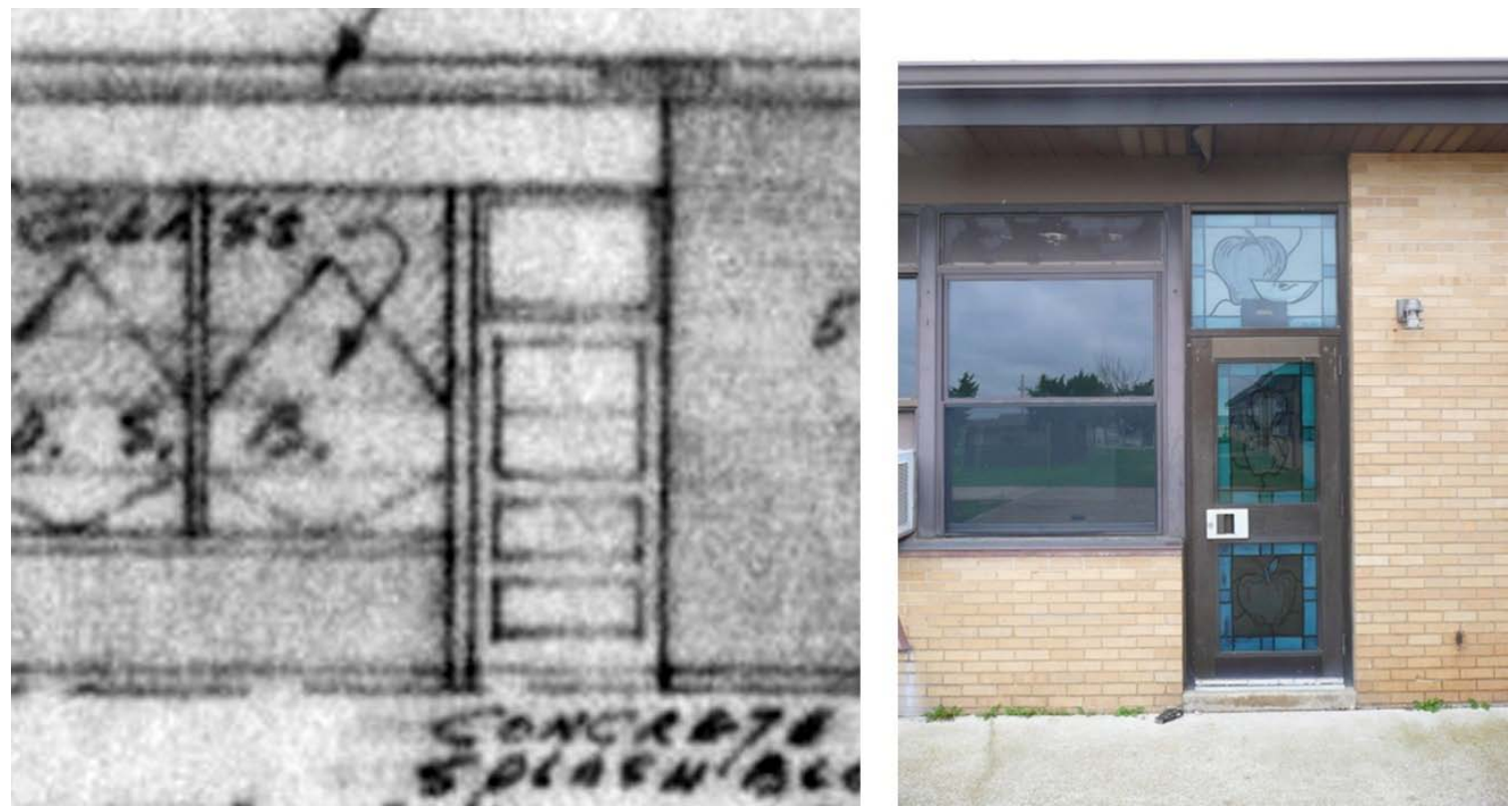

Figure 24. Entrance into the cafeteria on the east wall: original drawing on the left from 1954, compared to the current replacement door, transom, and windows in photo on the right.
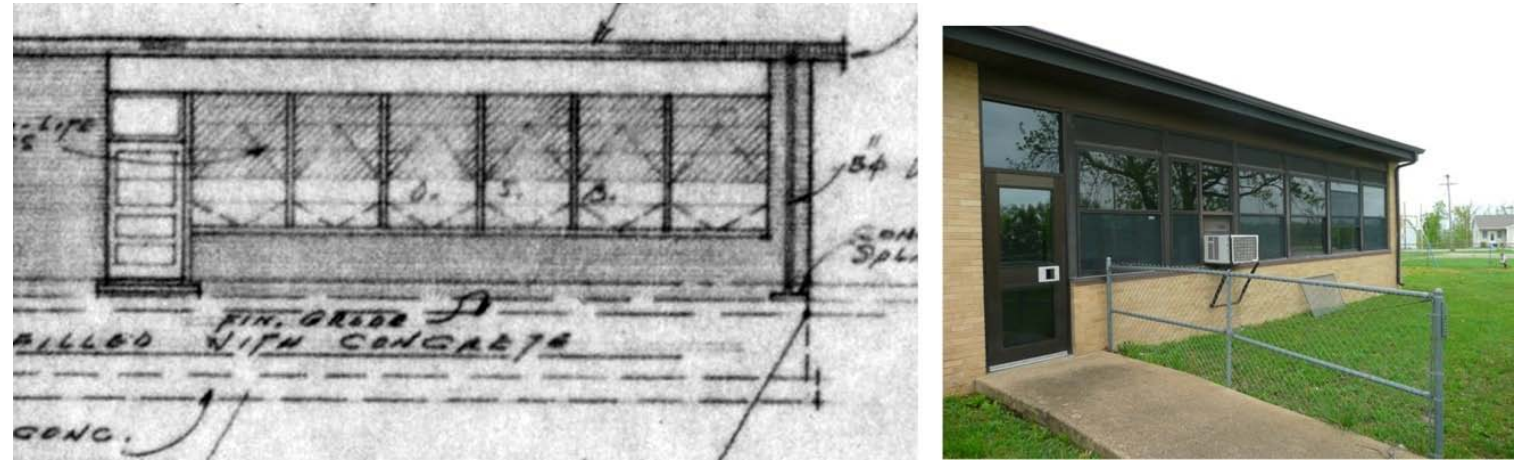

Figure 25. Right side of the west elevation: original drawing on the left from 1954, compared to the current replacement door, transom, and windows in photo on the right.
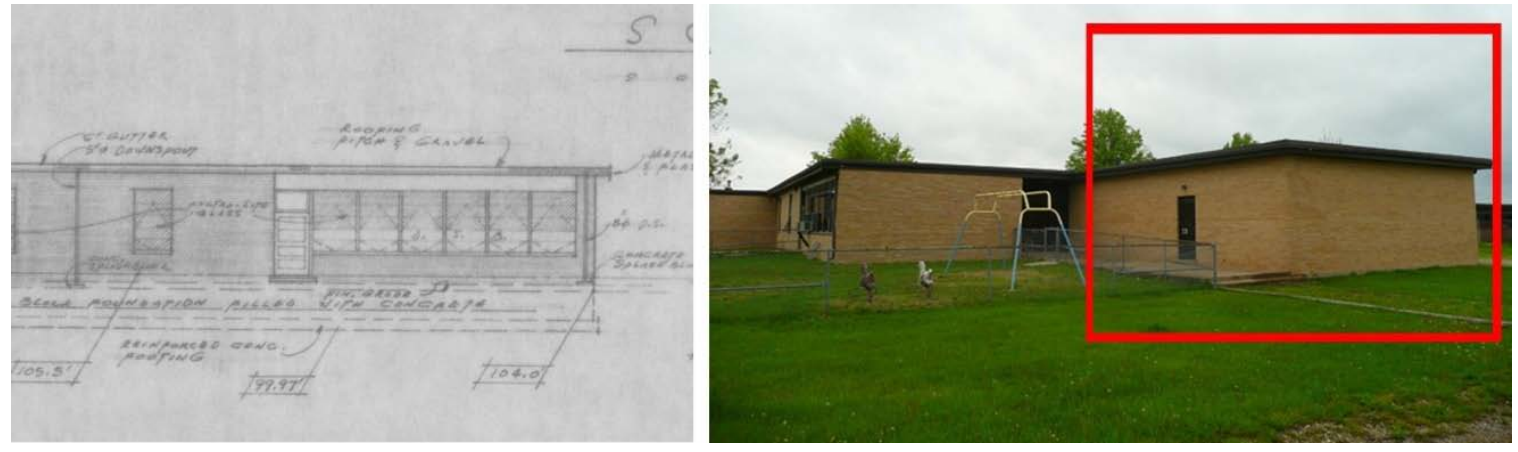

Figure 26. Cafeteria addition: original drawing on the left from 1954 with no expanded cafeteria space, compared to the current size of the cafeteria with the construction of an addition highlighted in red in photo on the right. 

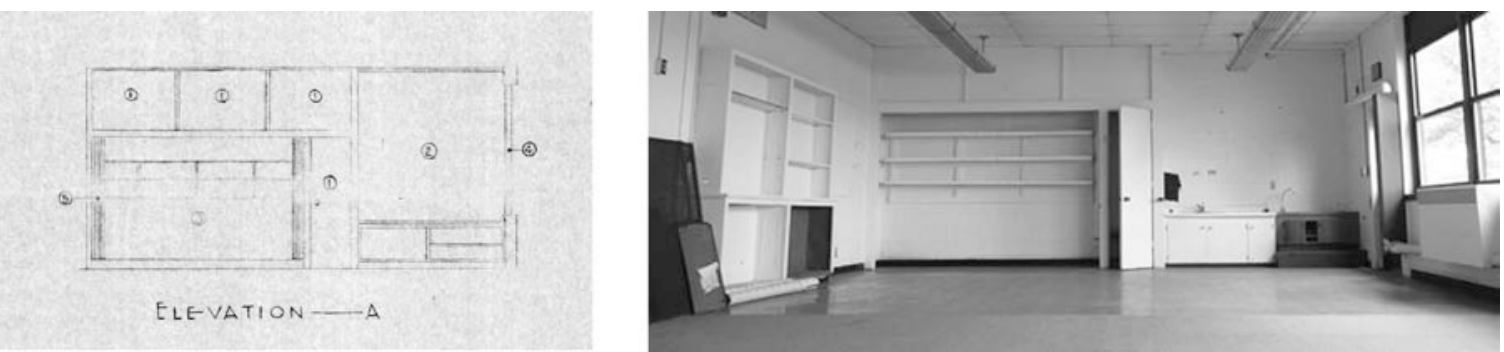

Figure 27. Classroom detail of coat "cubby" area, teacher's storage closet, and workstation with sink: original drawing on the left from 1954, compared to the current condition of a typical classroom detail in photo on the right.

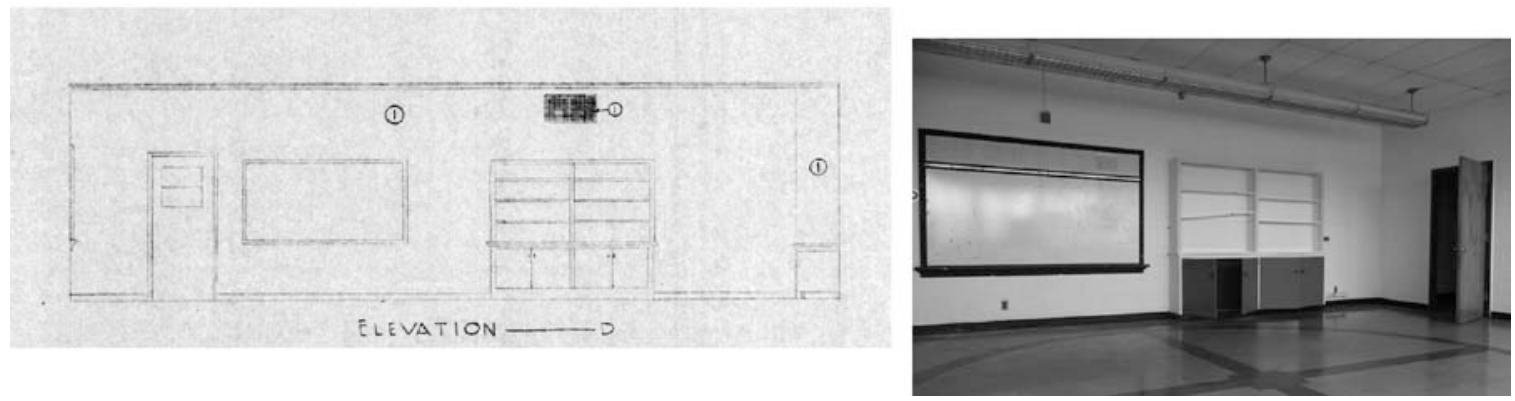

Figure 28. Classroom detail of storage shelf and tack board: original drawing on the left from 1954 , compared to the current condition of a typical classroom detail with a replacement whiteboard where the tack board used to be located in photo on the right.

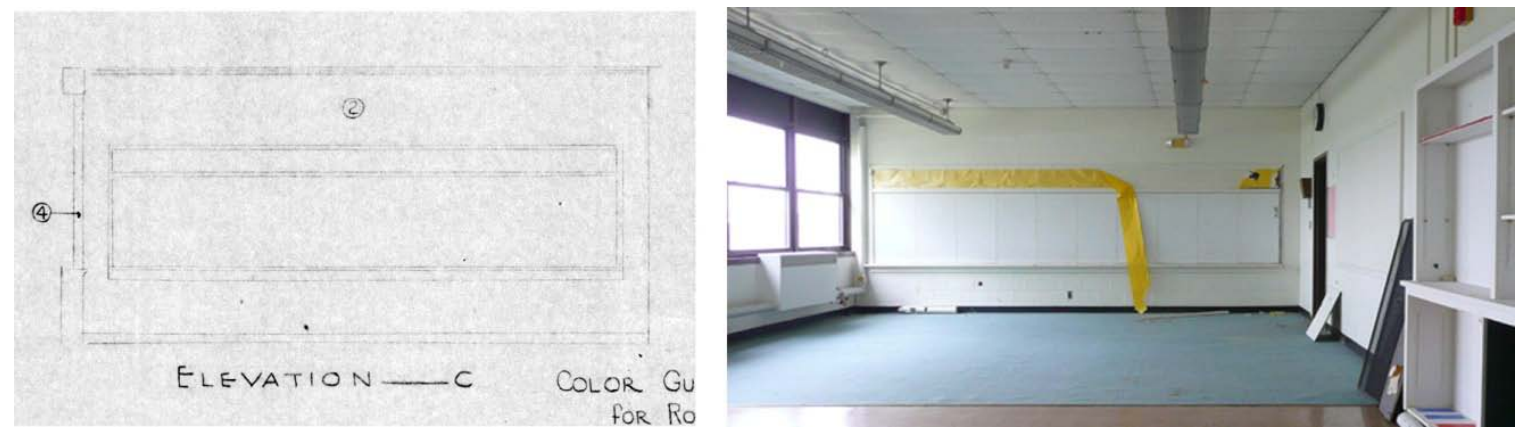

Figure 29. Classroom detail of chalkboard: original drawing on the left from 1954, compared to the current condition of a typical classroom detail where the original chalkboard has been replaced by a whiteboard in photo on the right.

\section{Finding for Criterion D - History}

The available historical records provided no indication that the school has yielded, or would be likely to yield, any information important in prehistory or history.

\section{Final Determination}

It is the determination of this report that Building 6824, Pence Elementary School, is NOT eligible to the National Register of Historic Places (NRHP) 
since it could not be related to a significant event for Criterion A, a significant person for Criterion B, a significant architect or design for Criterion $\mathrm{C}$, nor is it likely to yield information potential for Criterion D. 


\section{CERL Inventory Form}

\begin{tabular}{|c|c|c|c|}
\hline \multicolumn{4}{|c|}{$\begin{array}{l}\text { FORT LEONARD WOOD, MISSOURI } \\
\text { HISTORIC PROPERTY INVENTORY FORM }\end{array}$} \\
\hline $\begin{array}{l}\text { PROPERTY } \\
\text { BOUNDARIES } \\
\text { Rolla Street wraps around the } \\
\text { north and west sides of the } \\
\text { building } \\
\text { N ewburg Street is to the east } \\
\text { Pulaski Court is to the south } \\
\text { L ocated in Pulaski County, } \\
\text { M issouri }\end{array}$ & \multicolumn{2}{|c|}{$\frac{\text { COM M ON/HISTORIC NAME/BUILDING \# }}{\text { Pence Elementary School/B uilding } 6824}$} & $\frac{\text { STATUS }}{\text { Vacant }}$ \\
\hline $\begin{array}{l}\text { ARCHITECT/B UILDER } \\
\text { Dan R. Sandford \& Sons } \\
\text { A rchitects, Springfield- } \\
\text { K ansas City, M issouri }\end{array}$ & $\begin{array}{l}\text { DATE OF } \\
\text { CONSTRUCTION } \\
1954 \\
\text { DATE OF } \\
\text { ALTERATIONS } \\
\text { Unknown - addition on } \\
\text { the southwest corner; } \\
\text { 1986 replacement doors } \\
\text { and windows, modified } \\
\text { window pattern }\end{array}$ & $\frac{\text { NO. OF STORIES }}{1}$ & $\begin{array}{l}\text { FOOTPRINT } \\
\text { L-Shape }\end{array}$ \\
\hline$\frac{\text { ROOF FORM }}{\text { Flat }}$ & $\begin{array}{l}\text { FOUNDATION } \\
\text { Concrete }\end{array}$ & $\begin{array}{l}\text { WALLS } \\
\text { Concrete masonry units } \\
\text { with brick veneer }\end{array}$ & $\frac{\mathbf{R O O F}}{\text { Built-up }}$ \\
\hline $\begin{array}{l}\text { PROPERTY FUNCTION } \\
\text { HISTORIC USE(S) } \\
\text { Education }\end{array}$ & $\begin{array}{l}\text { CURRE NT USE } \\
\text { Vacant }\end{array}$ & \multirow{2}{*}{\multicolumn{2}{|c|}{$\begin{array}{l}\text { NOTABLE FEATURES } \\
\text { o L-shape footprint modified with an addition on } \\
\text { the southwest corner (cafeteria enlargement) } \\
\text { o One-story } \\
\text { o Brick veneer exterior walls } \\
\text { o Flat roof } \\
\text { o M odified window patterns with the addition of } \\
\text { replacement windows and new door openings } \\
\text { o Replacement wood interior doors (with the ex- } \\
\text { ception of one original in Health Room N o. 5) } \\
\text { o Original classroom configuration } \\
\text { o Original bathroom fixtures } \\
\text { o Original wood three-light vestibule doors and } \\
\text { fixed transoms }\end{array}$}} \\
\hline \multicolumn{2}{|c|}{$\begin{array}{l}\text { RELATIONSHIP TO OTHER B UIL DING S } \\
\text { Building } 6824 \text { is located on the northwest corner of the } \\
\text { cantonment and is surrounded by M ark Twain N ational } \\
\text { Forest. The building is situated in the Eagle Point neigh- } \\
\text { borhood. The school is northwest of the intersection of } \\
\text { Indiana A venue and Pulaski A venue. }\end{array}$} & & \\
\hline
\end{tabular}




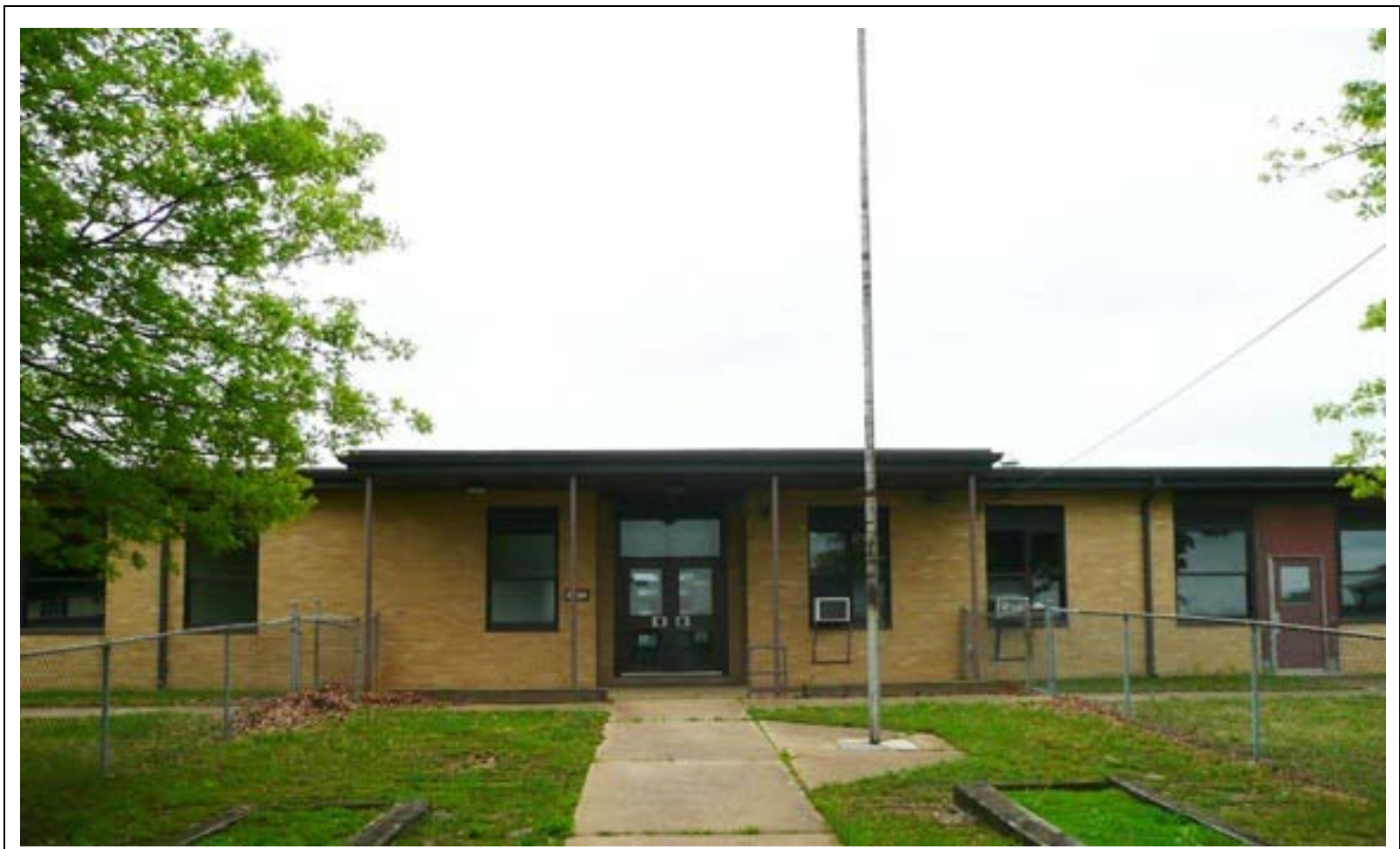

Photo 1. M ain entrance on the north elevation.

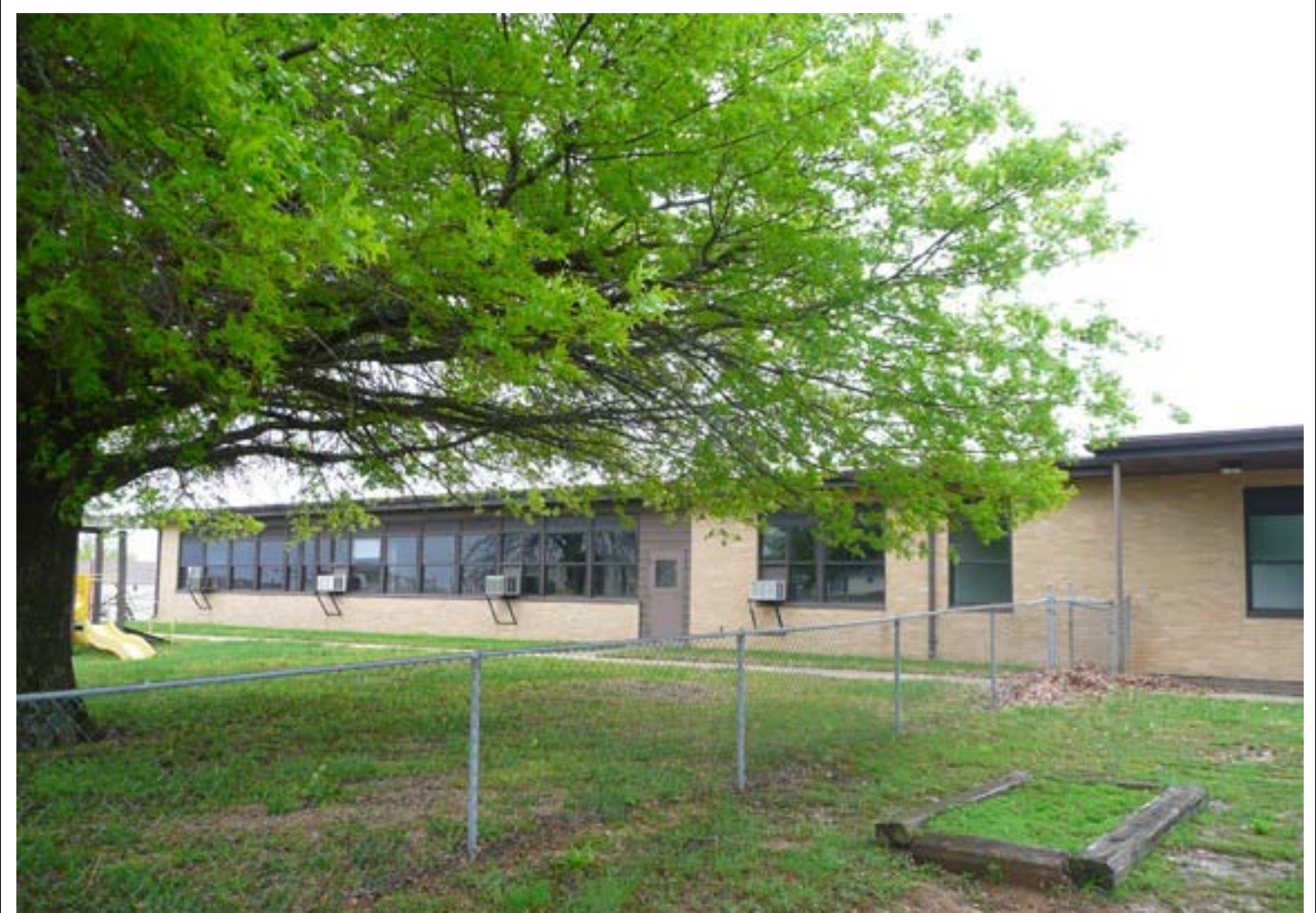

Photo 2. L eft side of the north elevation. 


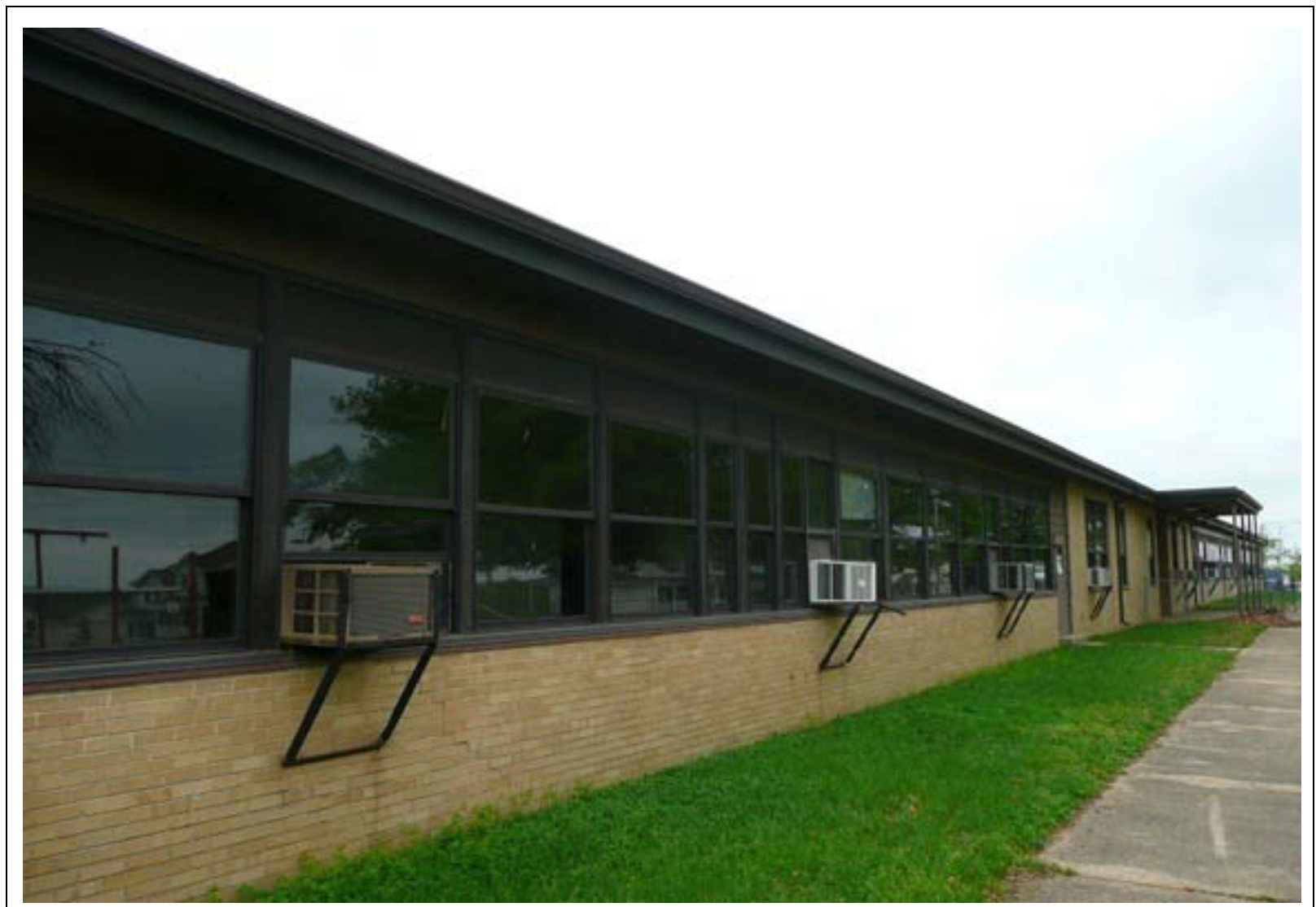

Photo 3. Replacement windows and modified window pattern.

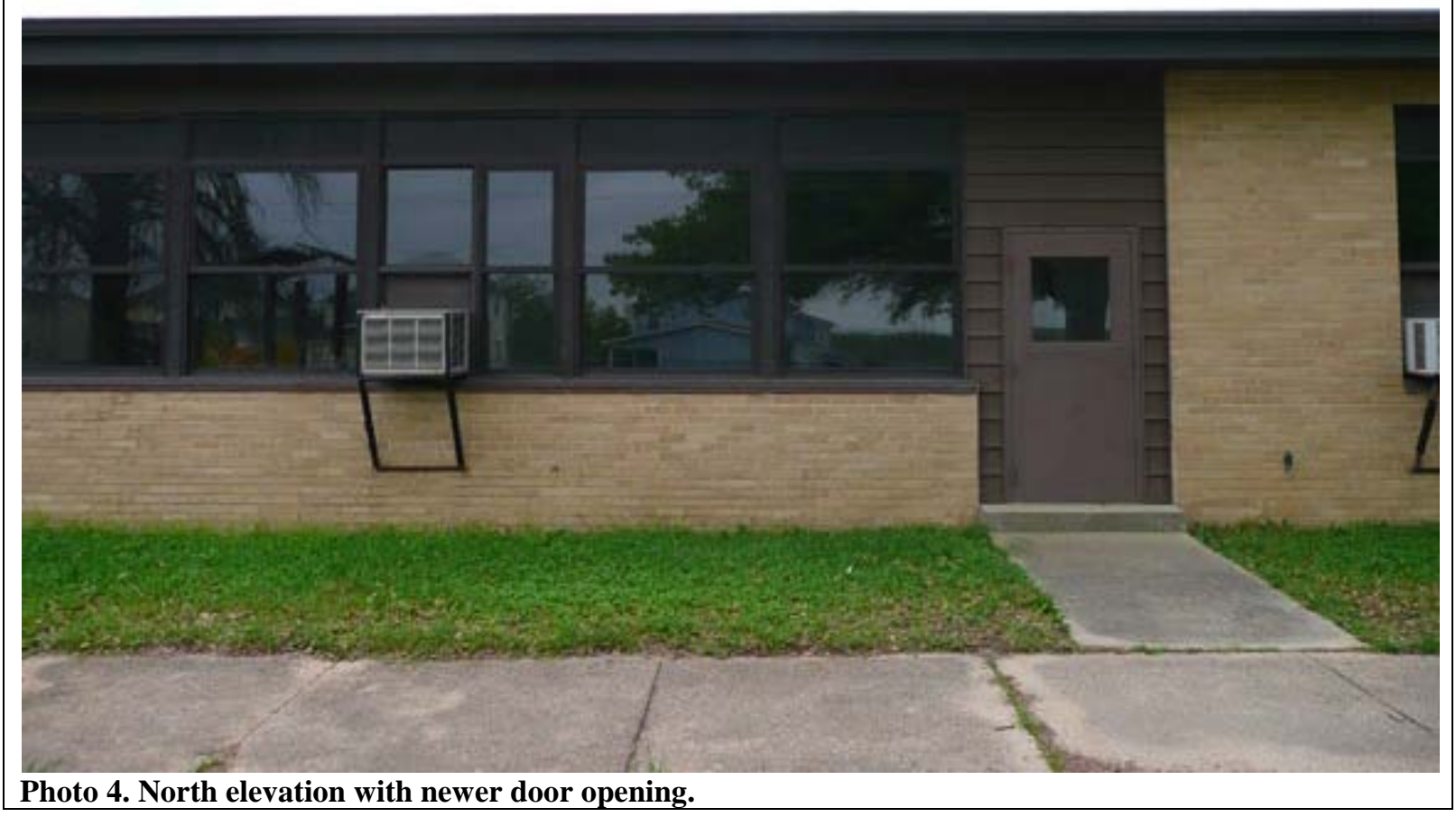




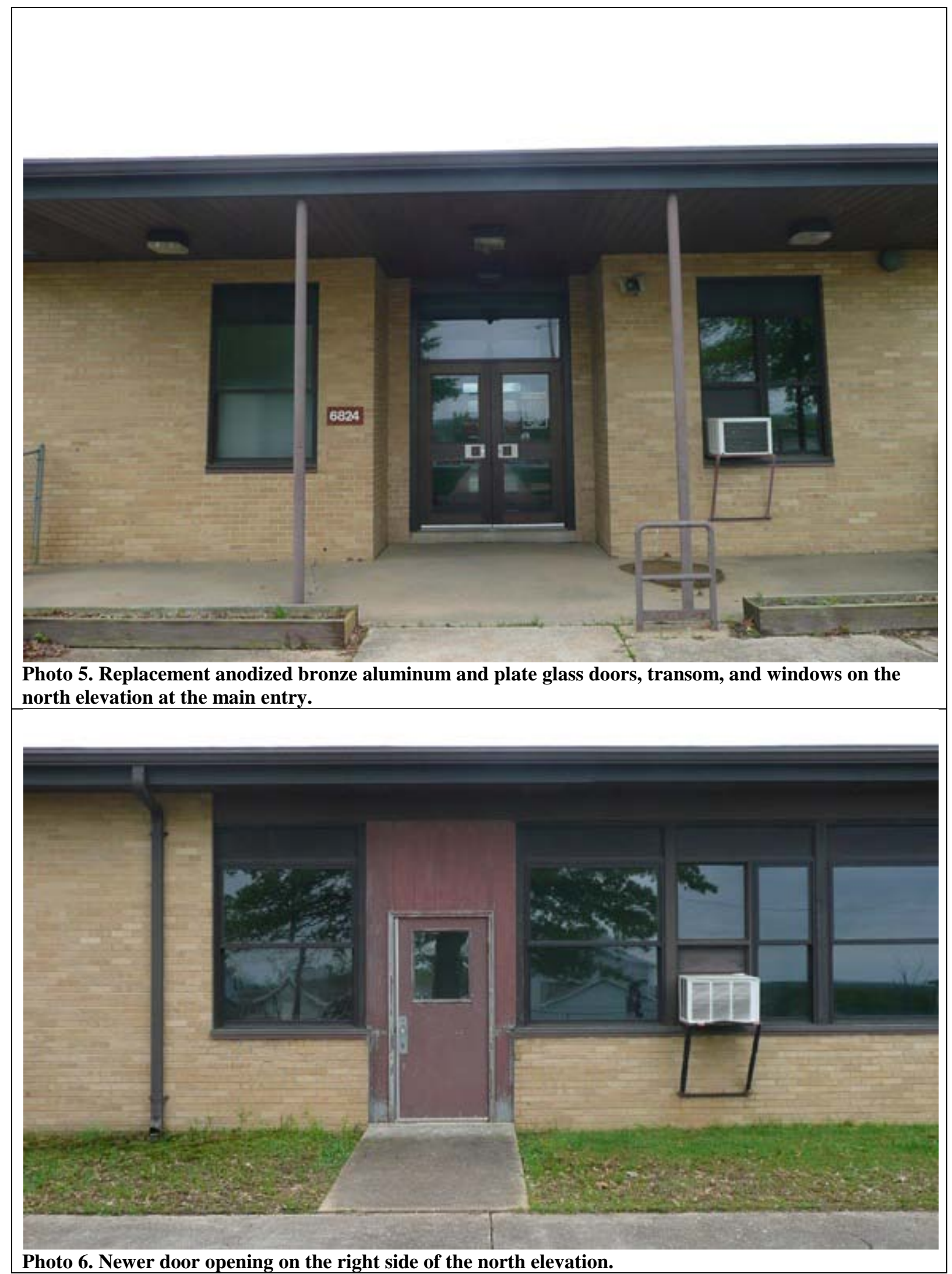




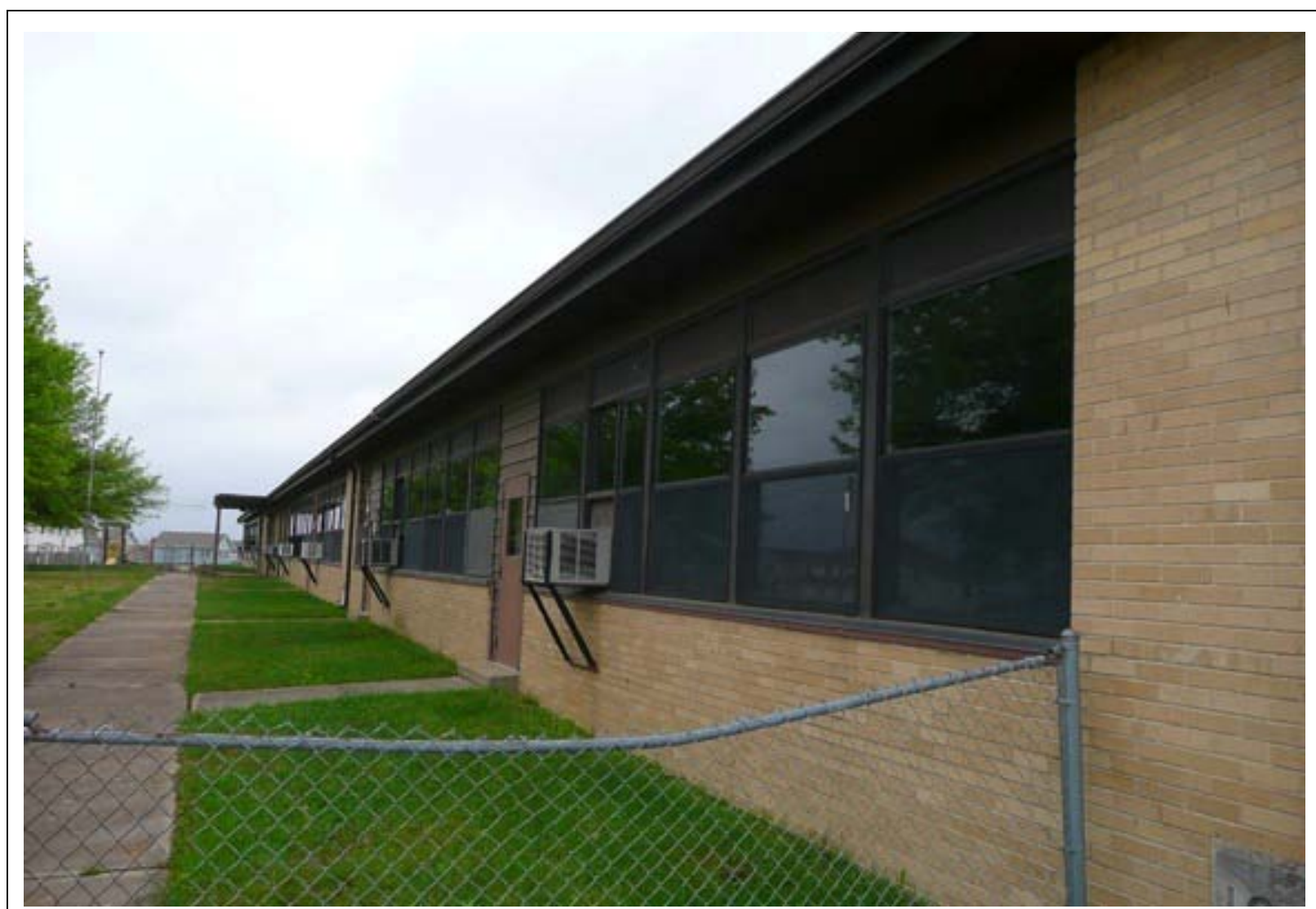

Photo 7. L ooking back west toward the north elevation.

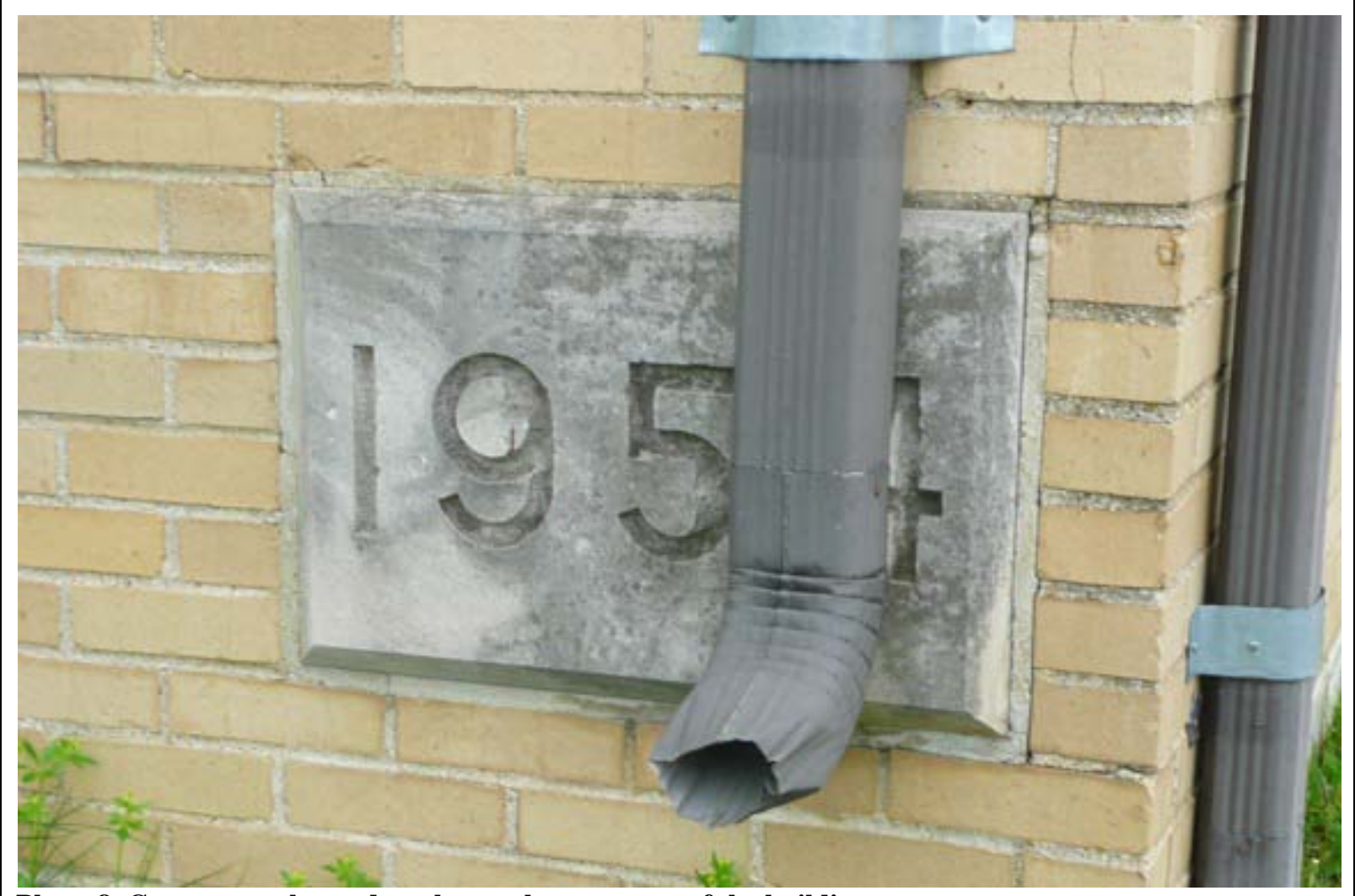

Photo 8. Cornerstone located on the northeast corner of the building. 


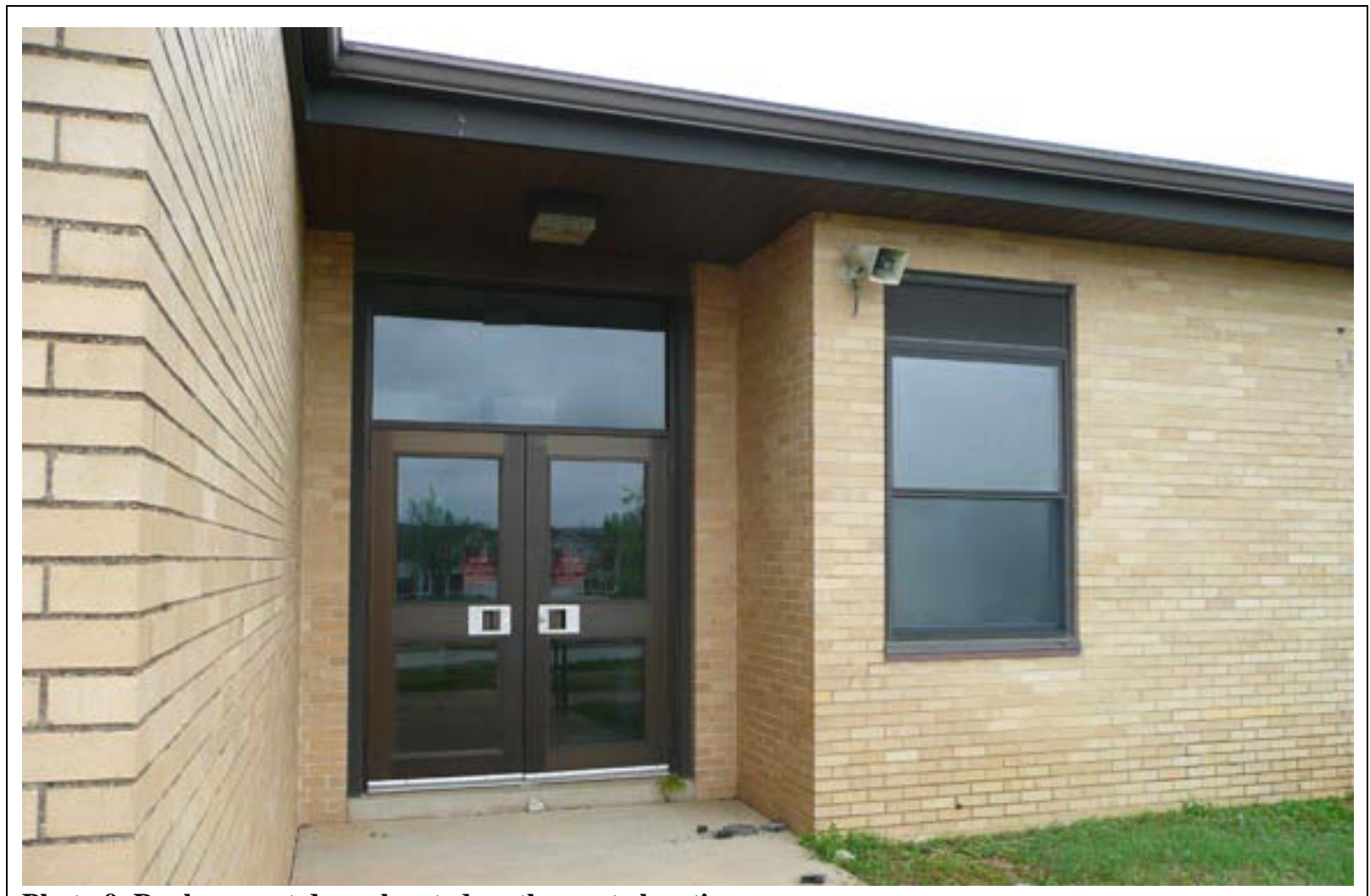

Photo 9. Replacement doors located on the west elevation.

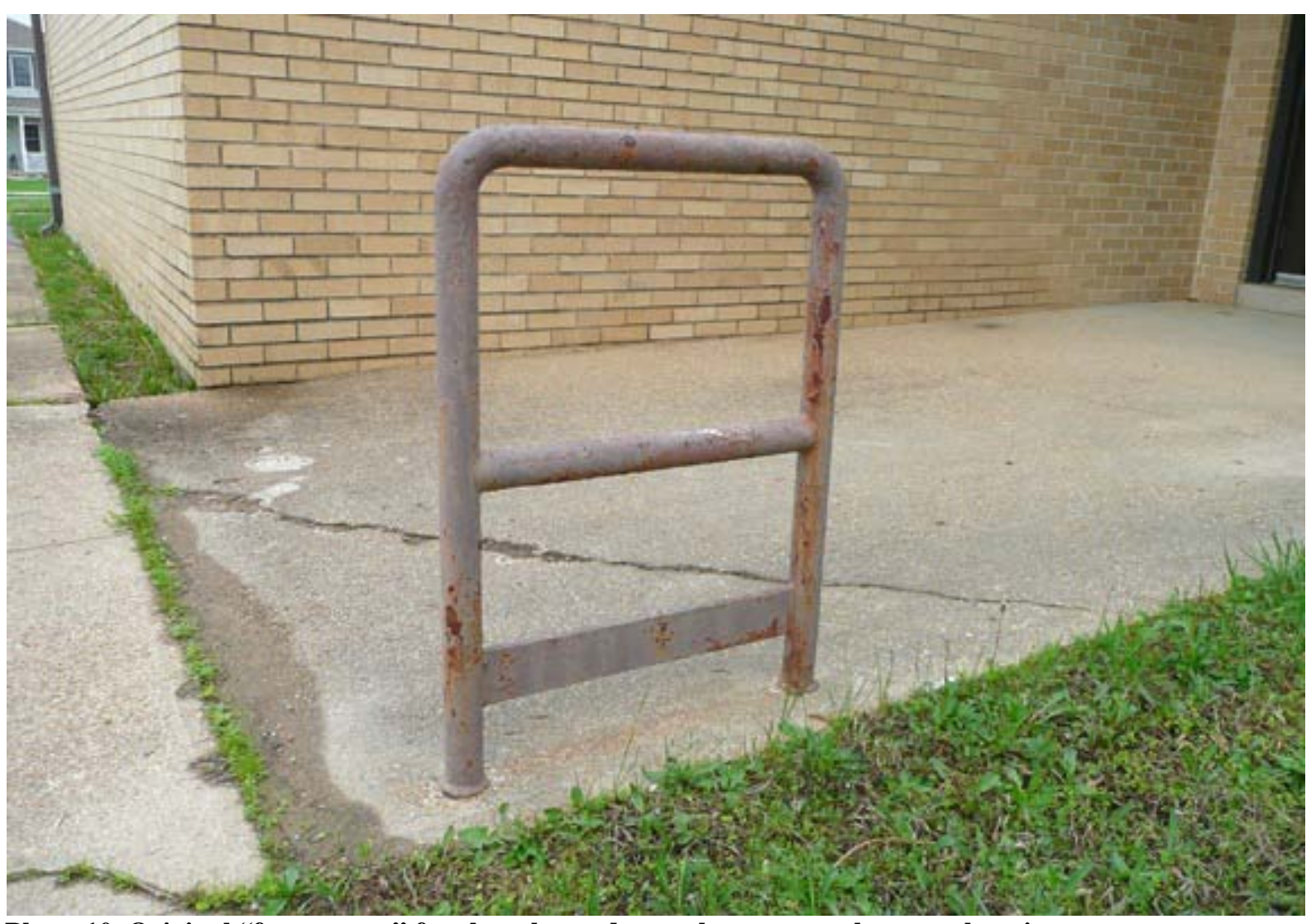

Photo 10. Original "footscraper" for shoes located near the entry on the west elevation. 


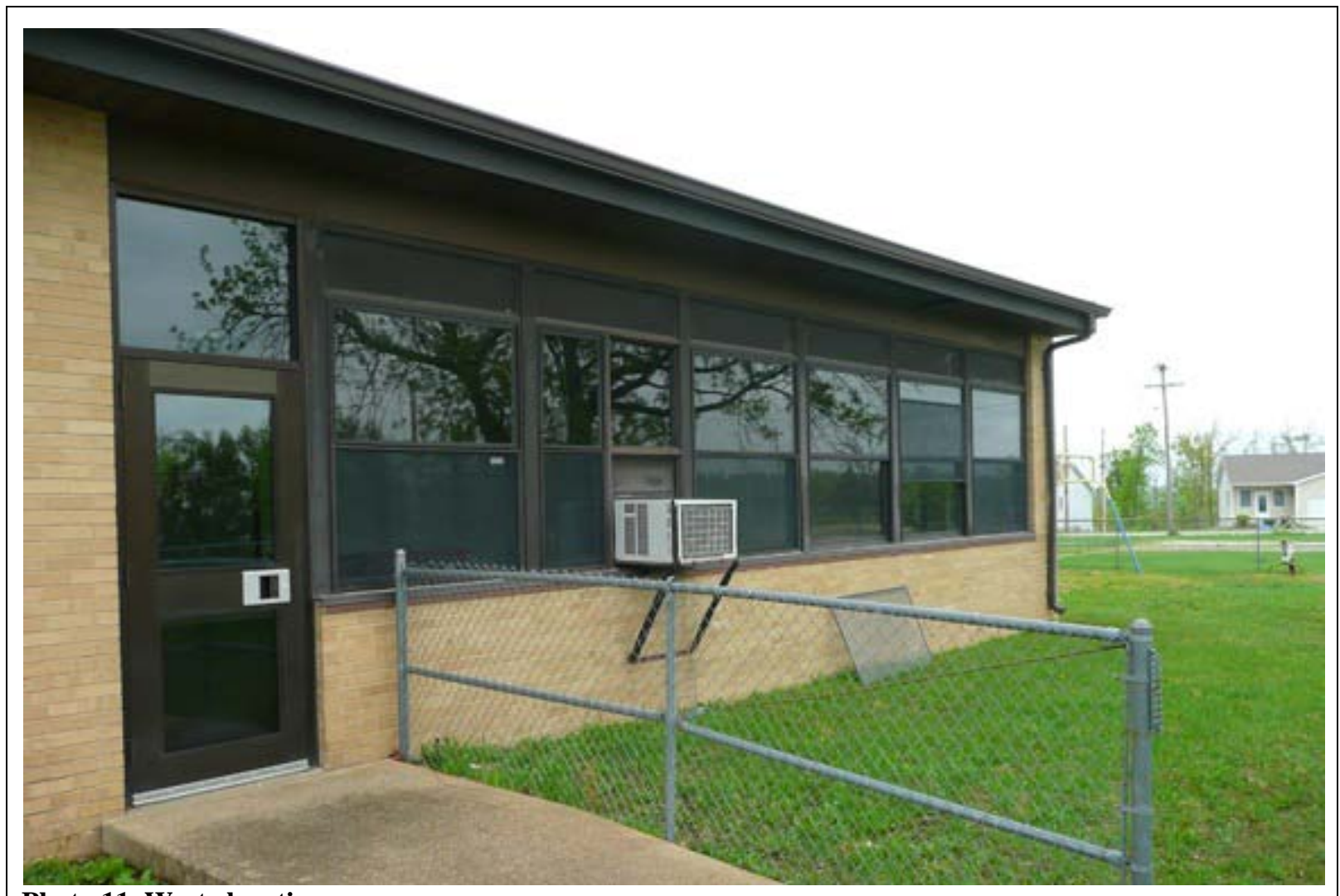

Photo 11. West elevation.

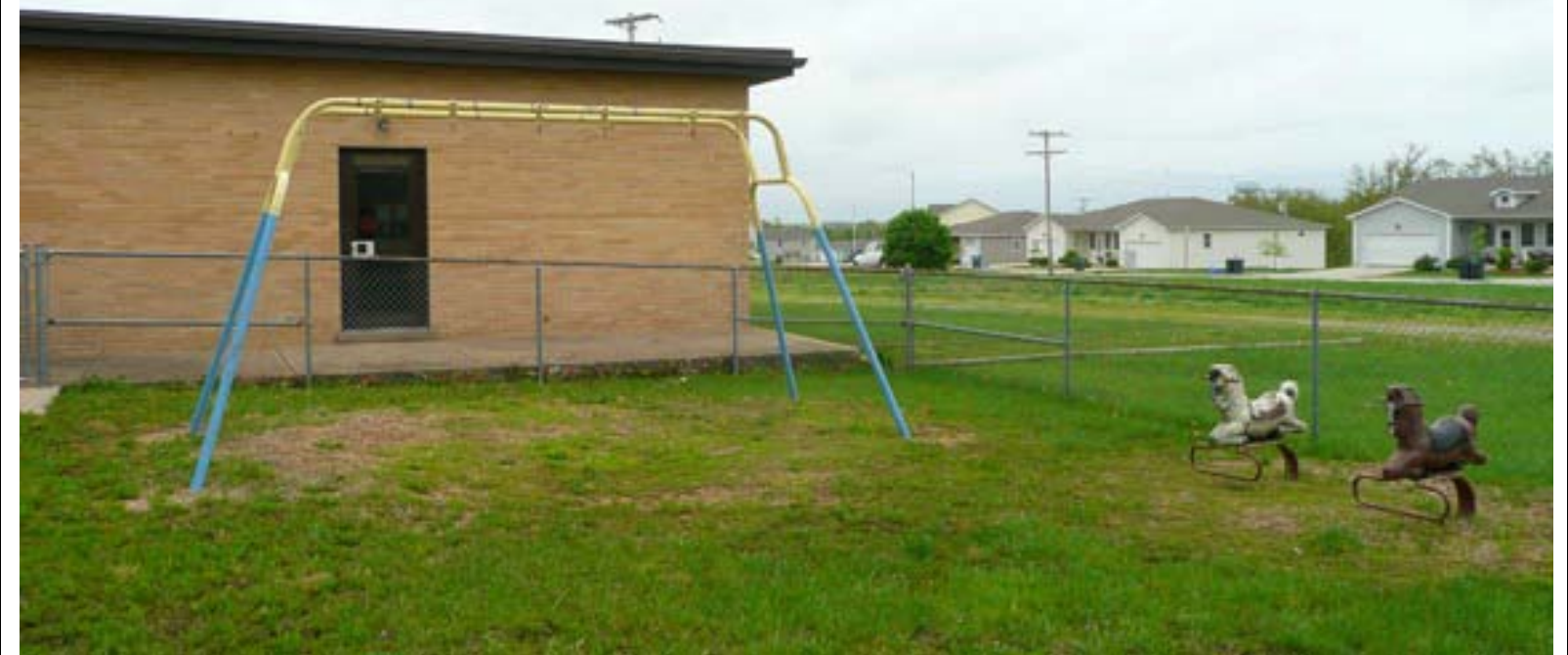

Photo 12. West elevation with some original playground fixtures; photo also is looking at the addition to the cafeteria. 


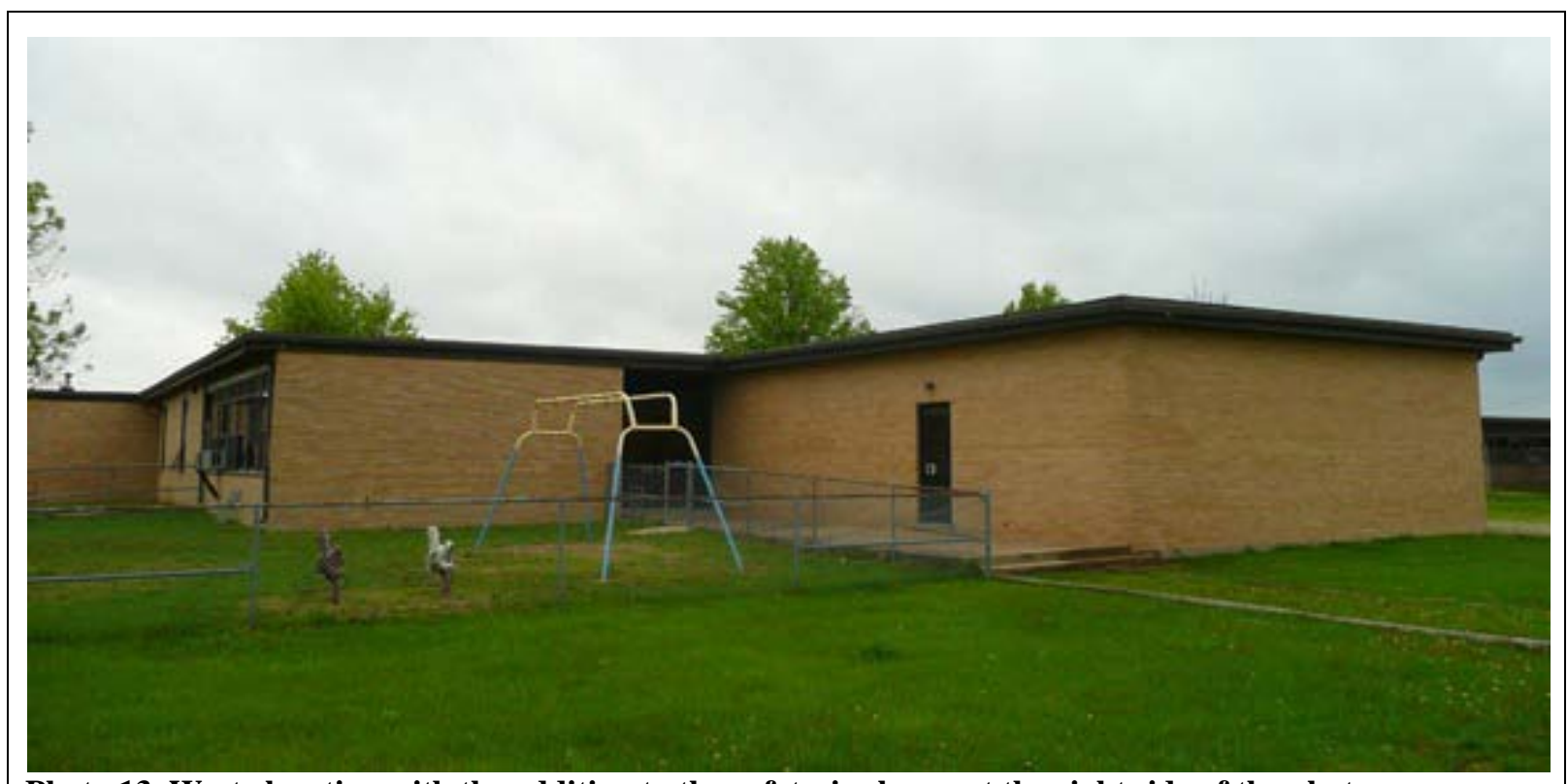

Photo 13. West elevation with the addition to the cafeteria shown at the right side of the photo.

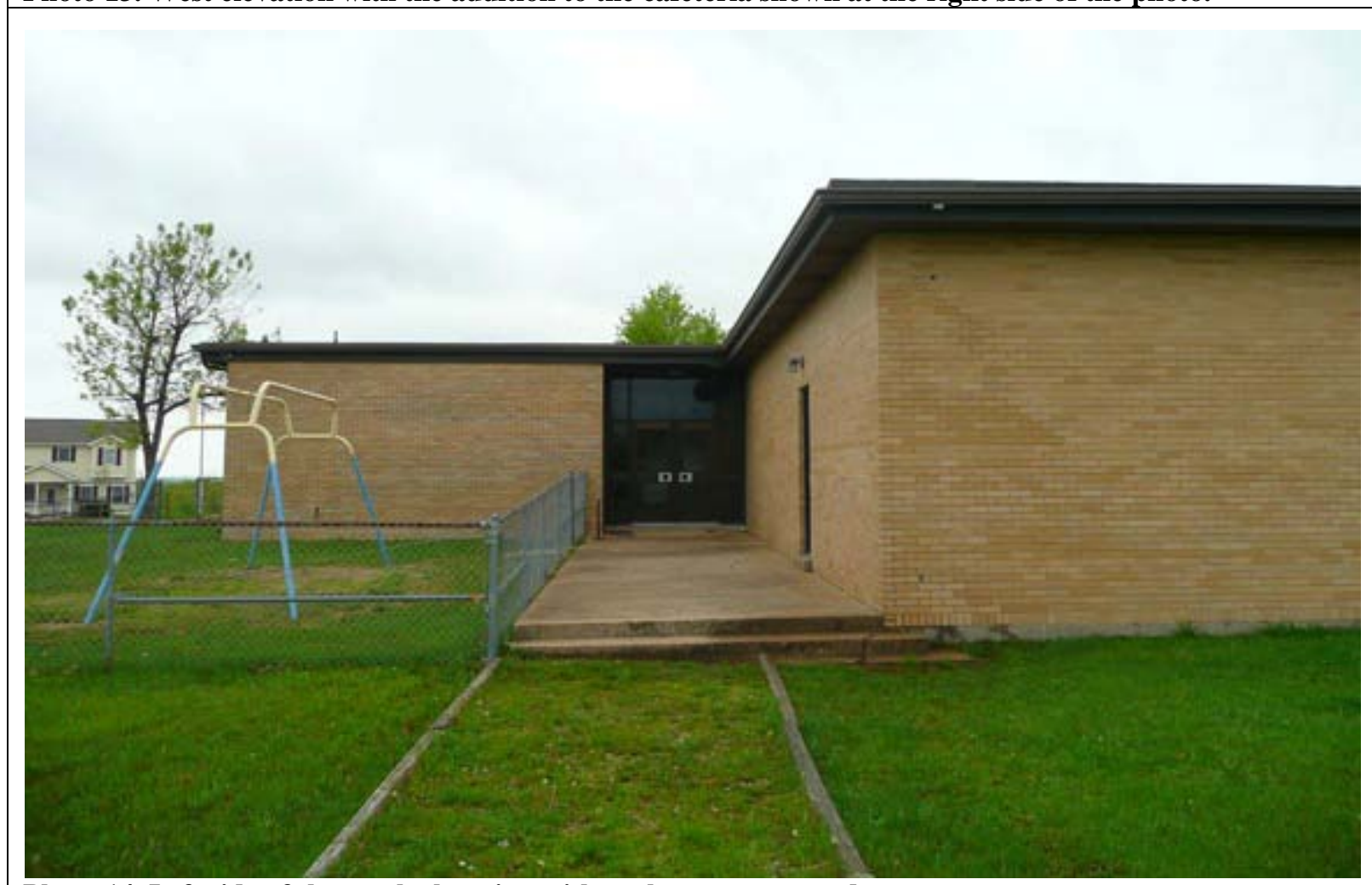

Photo 14. L eft side of the south elevation with replacement entry doors. 


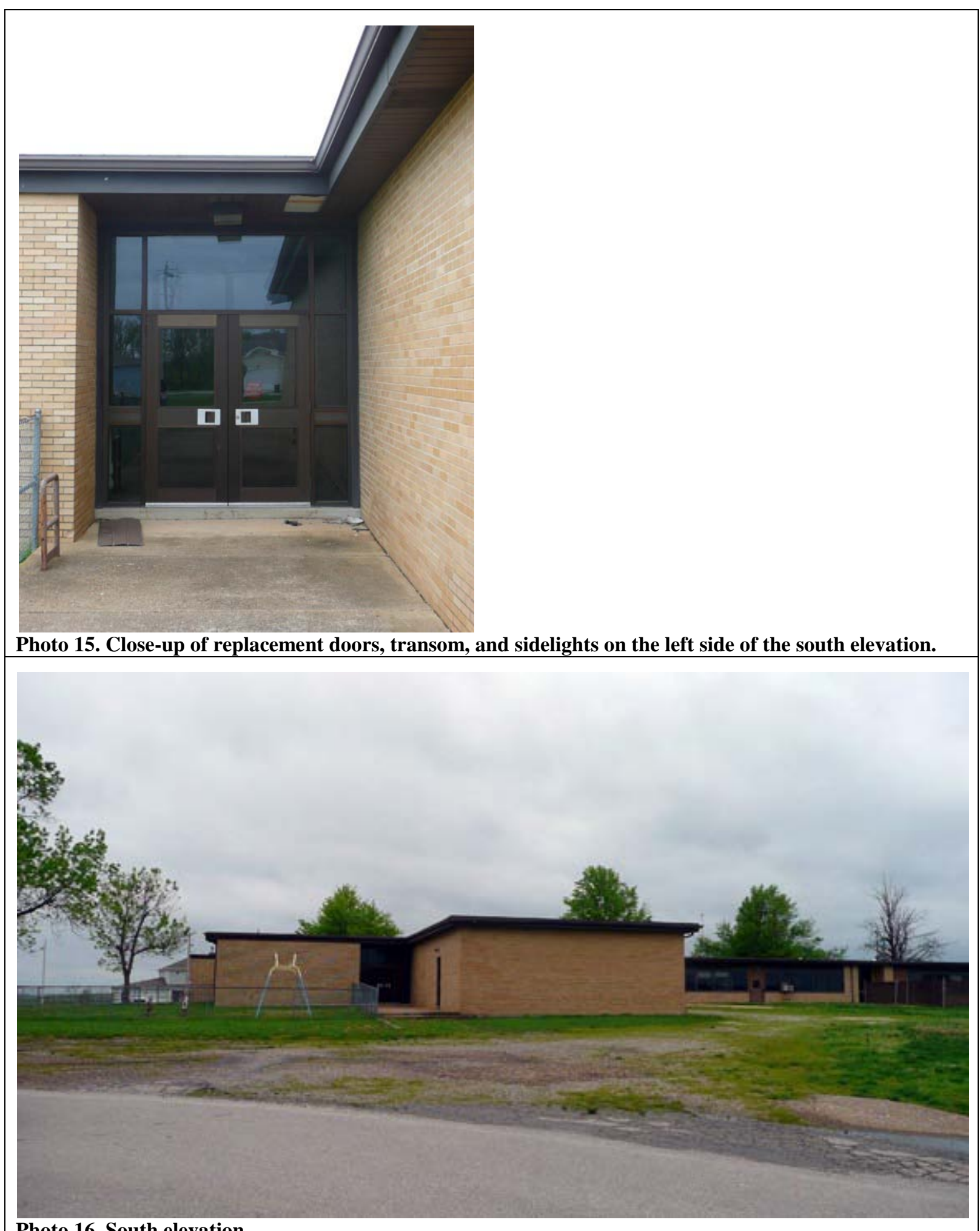

Photo 16. South elevation. 


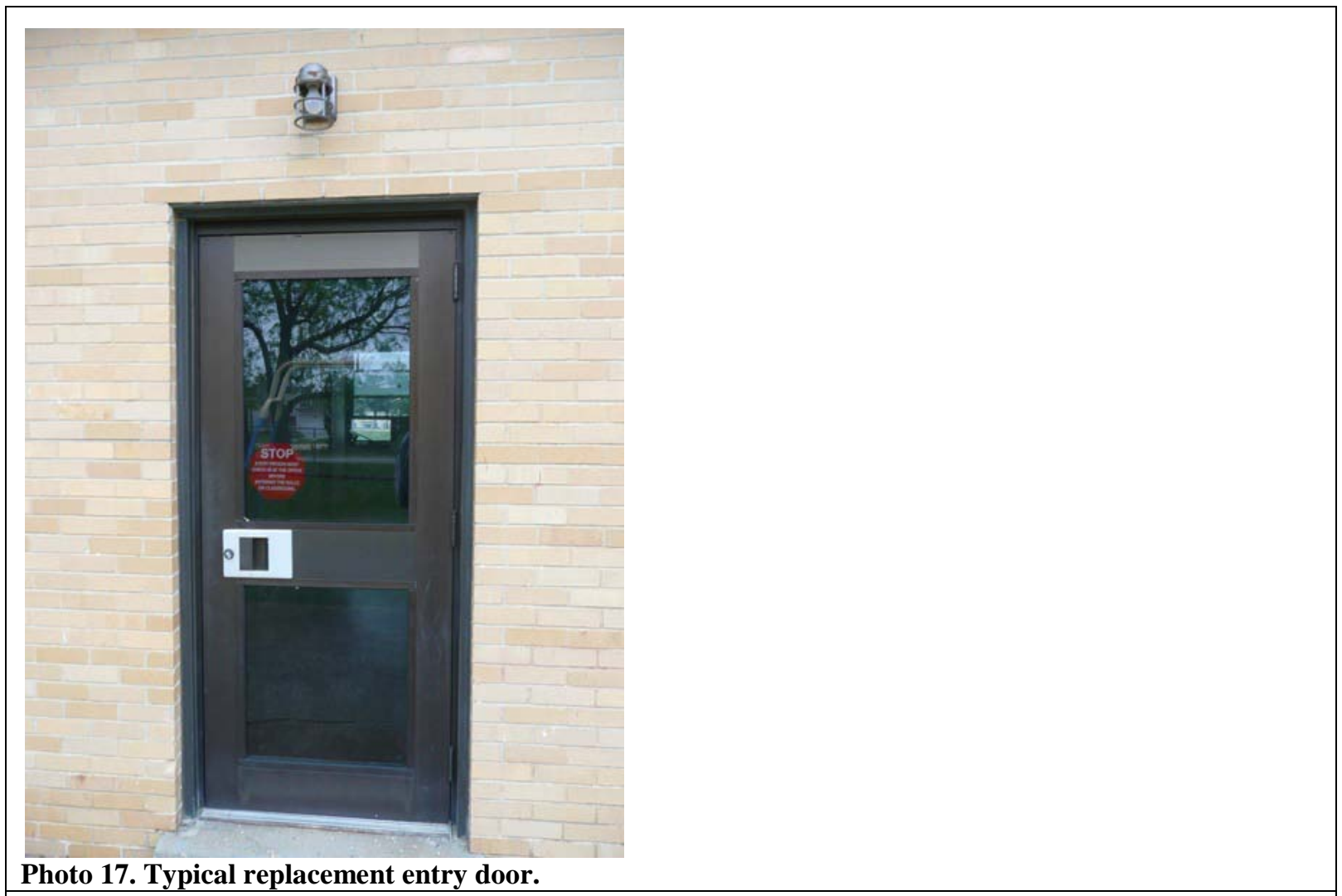

Photo 17. Typical replacement entry door.

Photo 18. Typical replacement one-over-one double-hung windows on the addition portion of the cafeteria. 


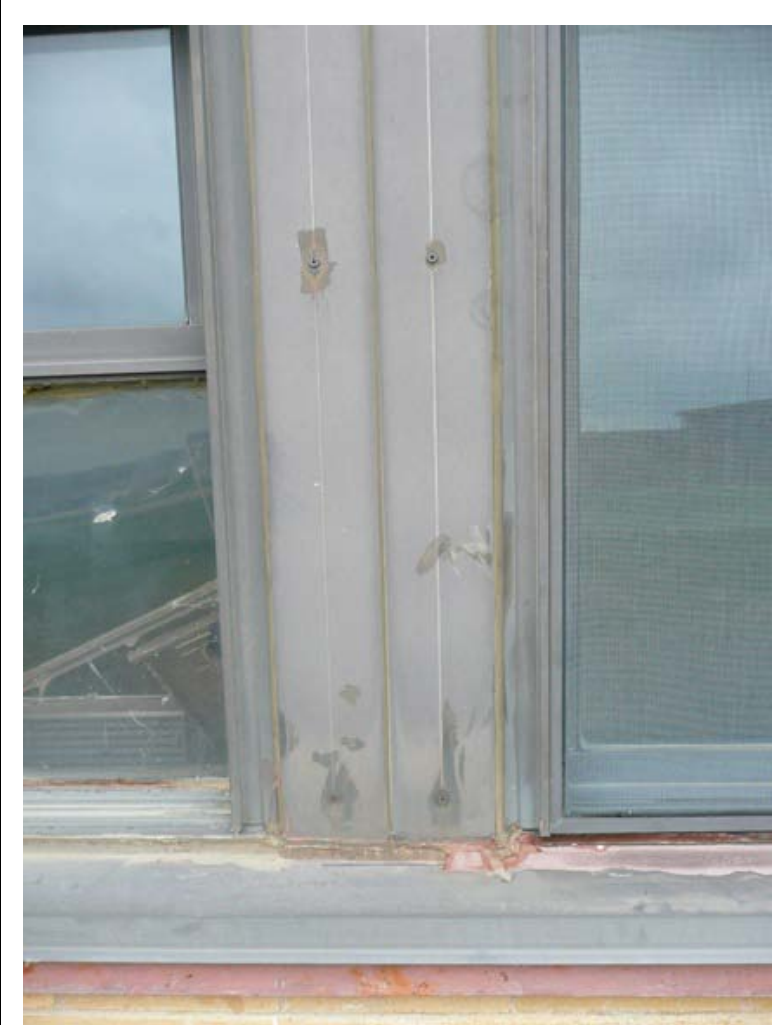

Photo 19. Close-up of replacement window and windowsill.

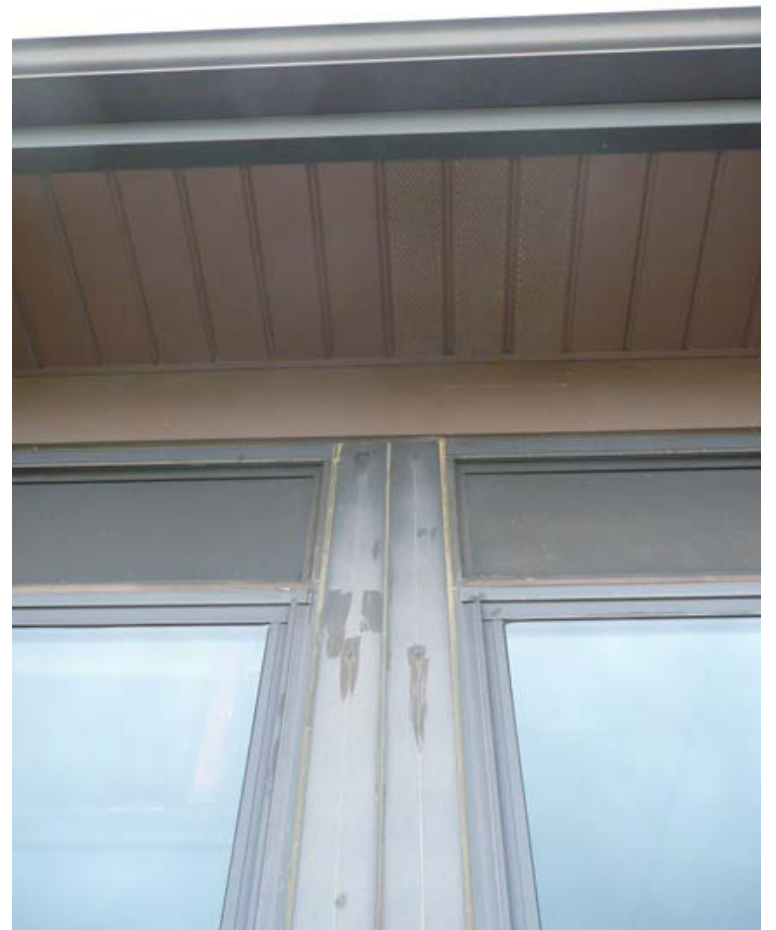

Photo 20. R eplacement aluminum soffit and gutters. 


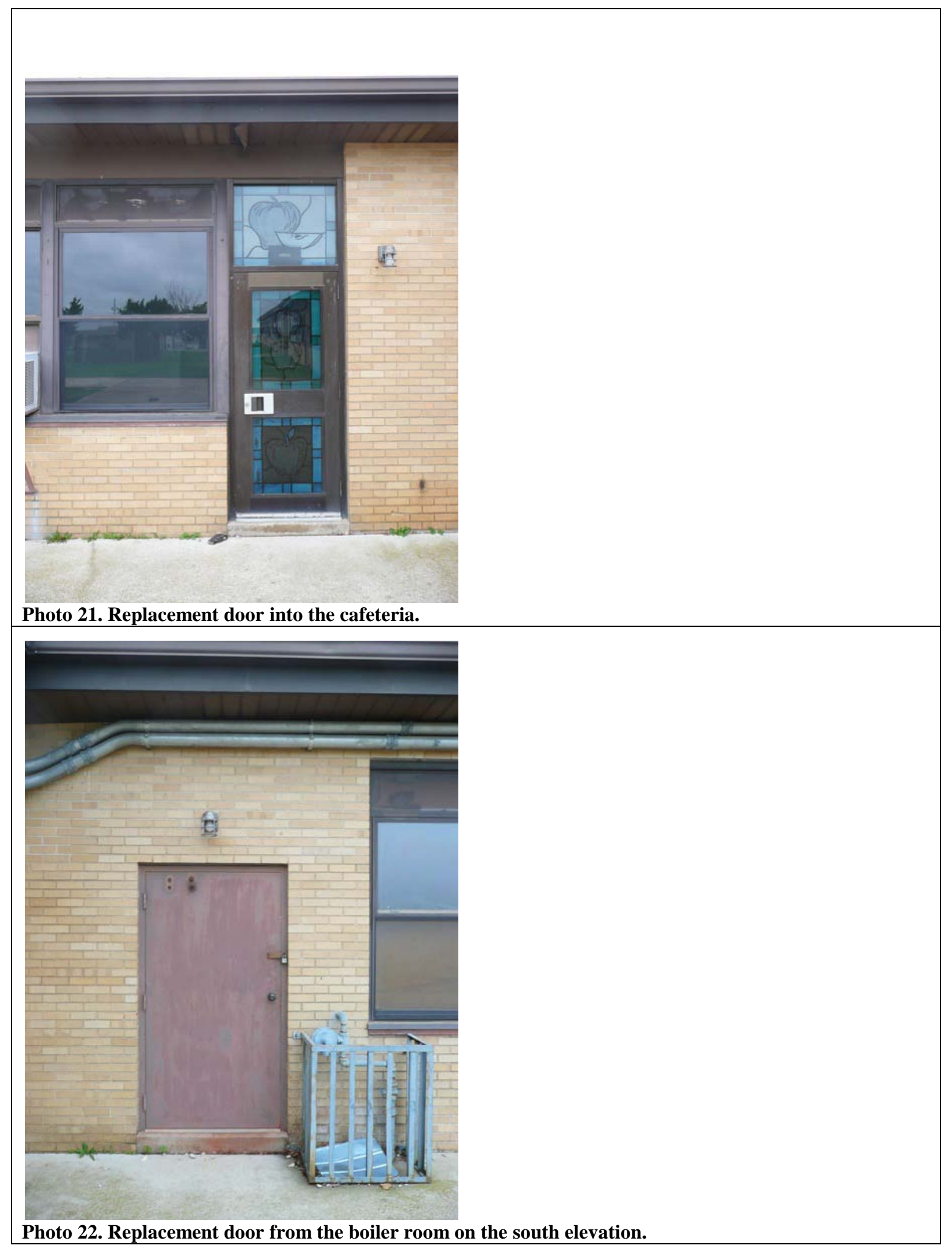




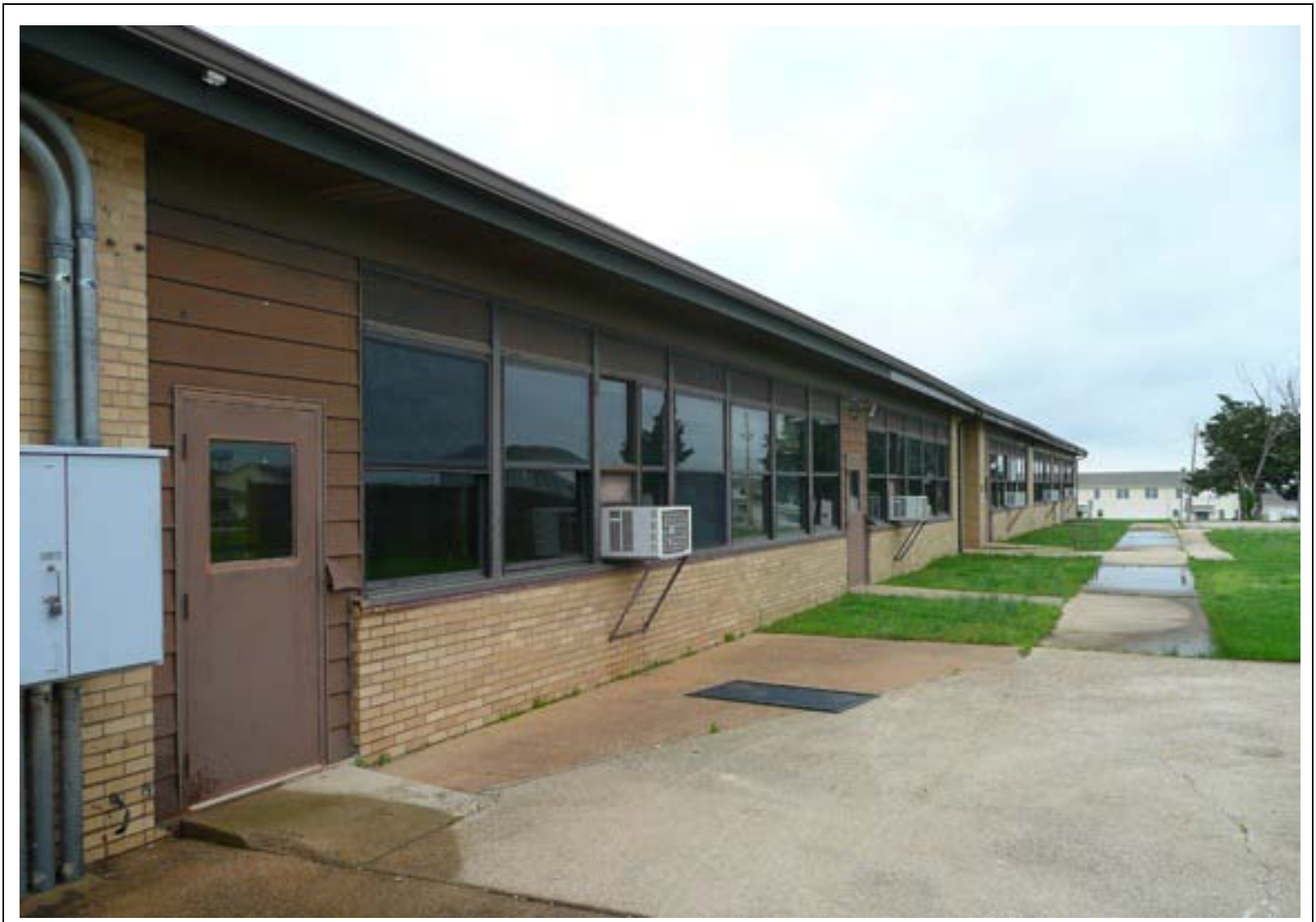

Photo 23. The east end of the south elevation.

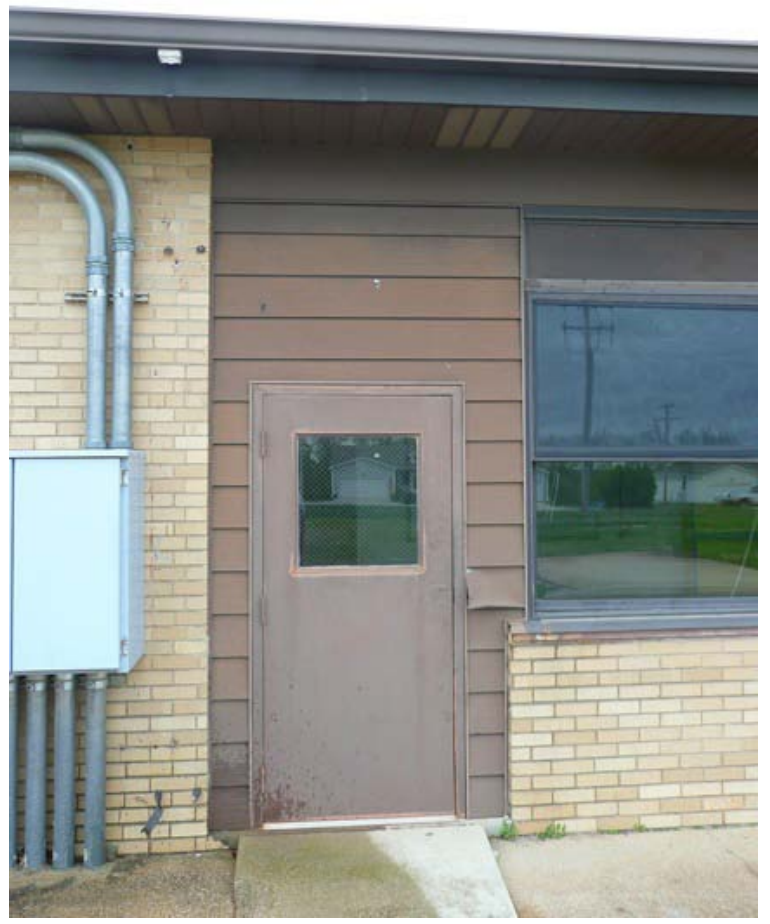

Photo 24. Typical modified door opening leading into classroom space. 


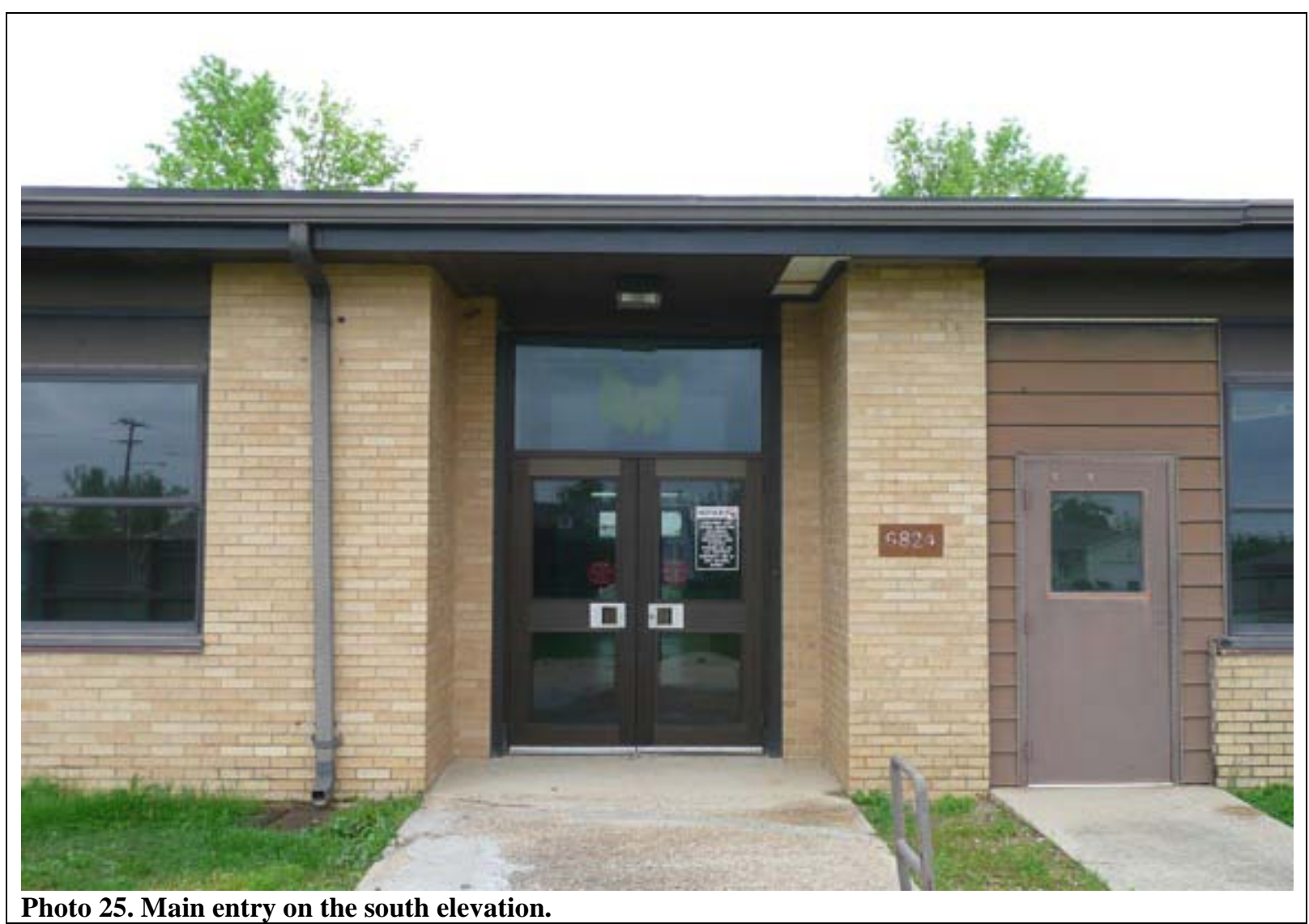

Photo 25. M ain entry on the south elevation.

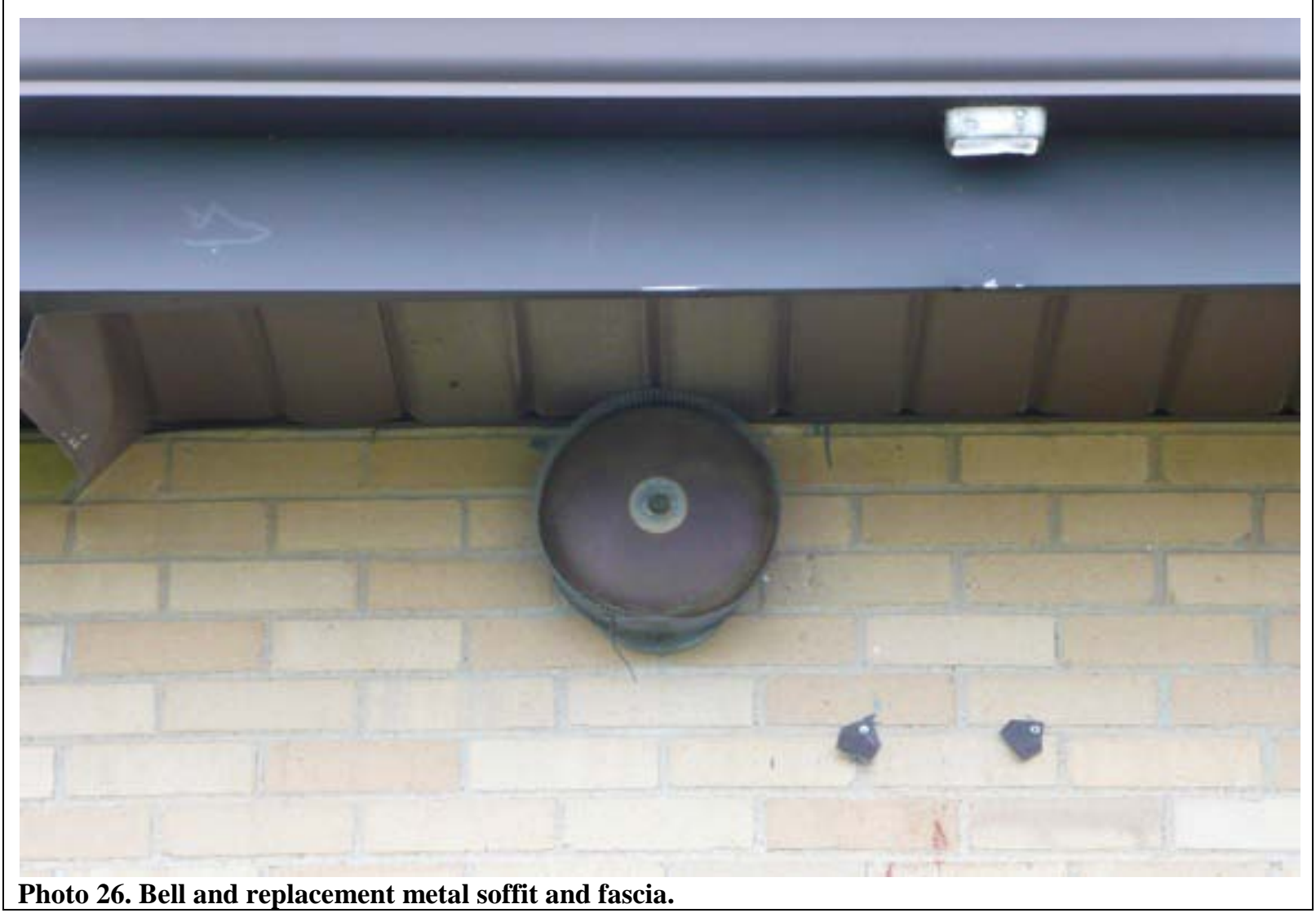




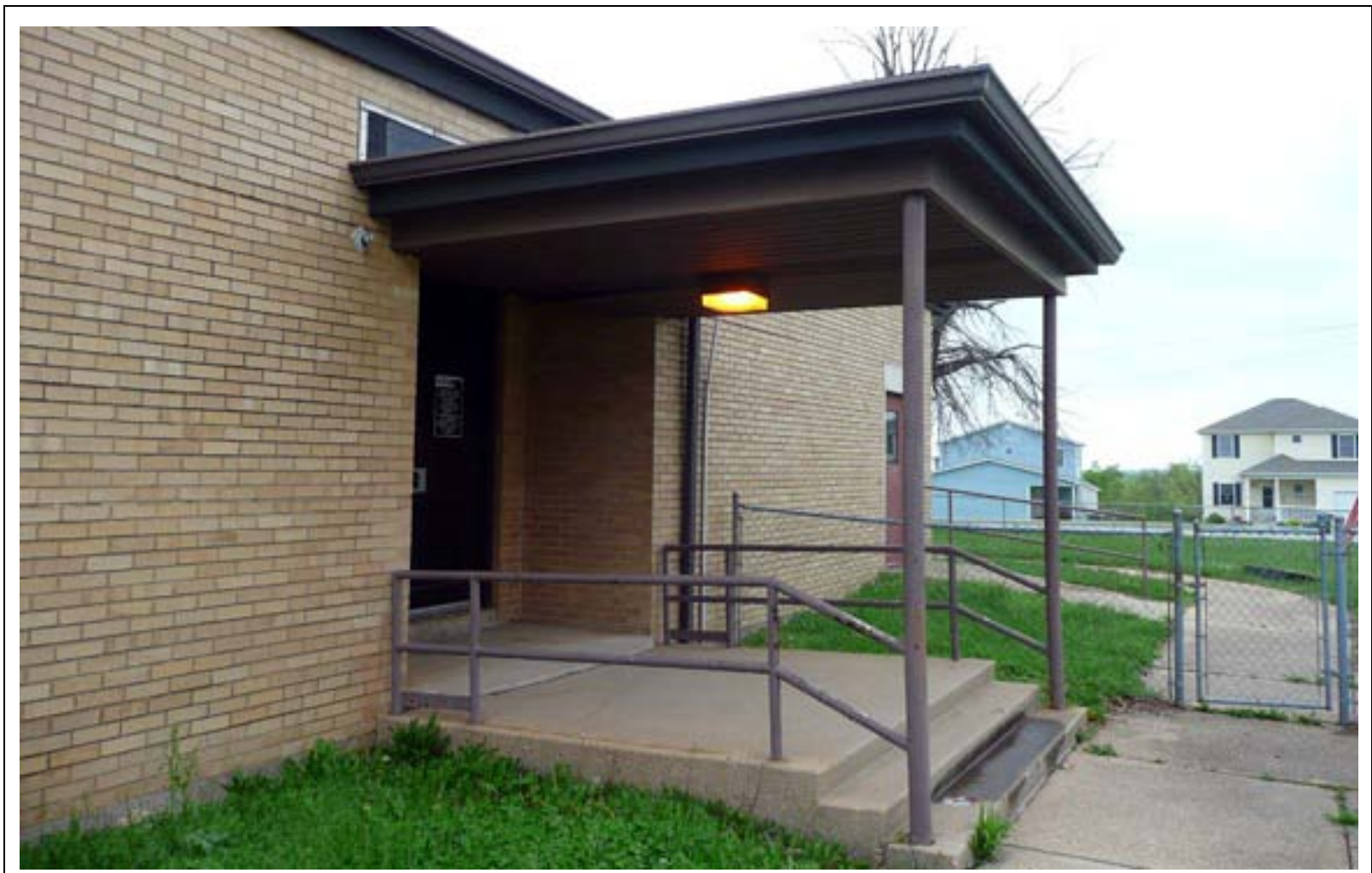

Photo 27. E ntry on the east elevation with original railings, columns, post, and canopy structure.

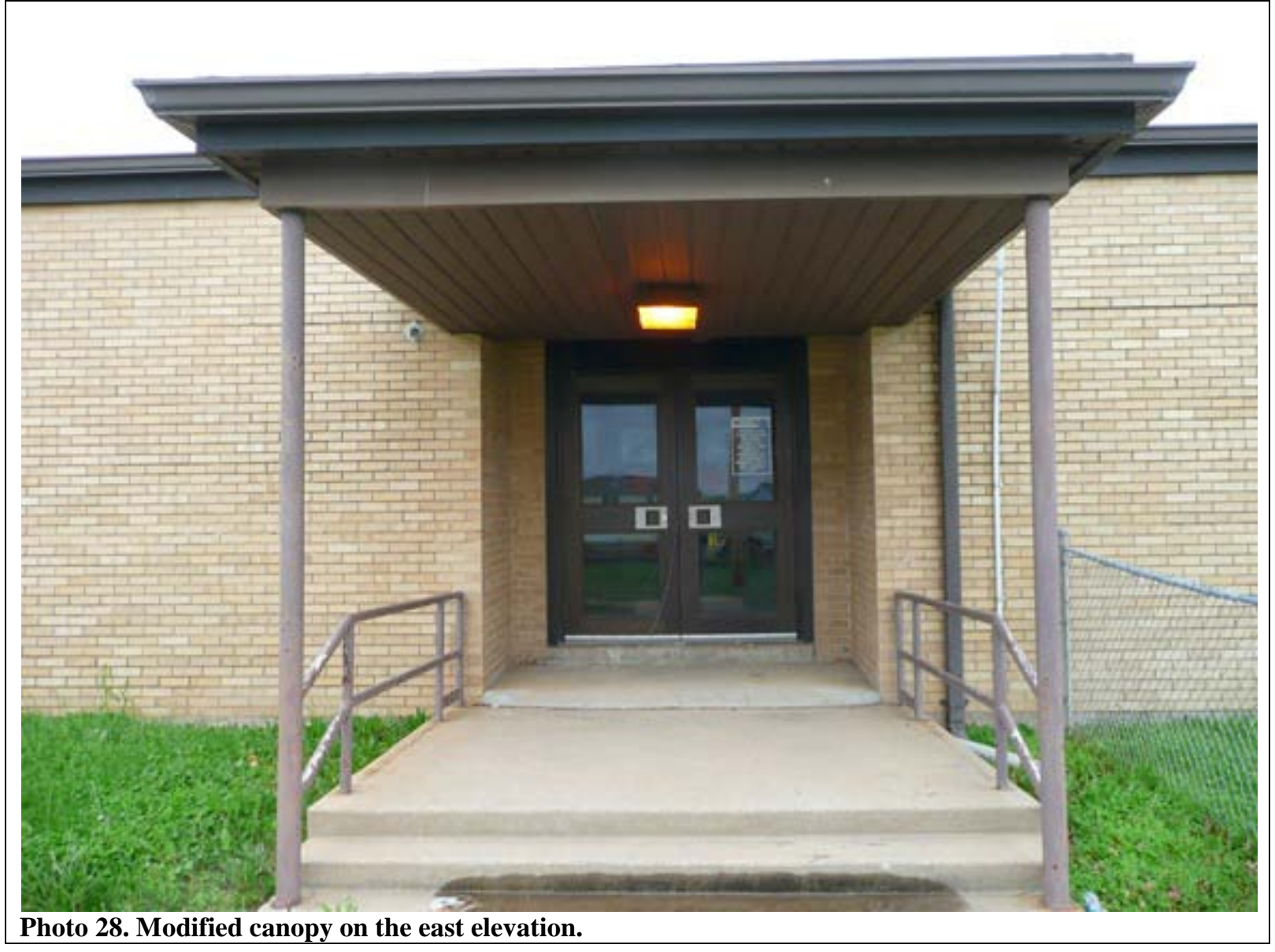




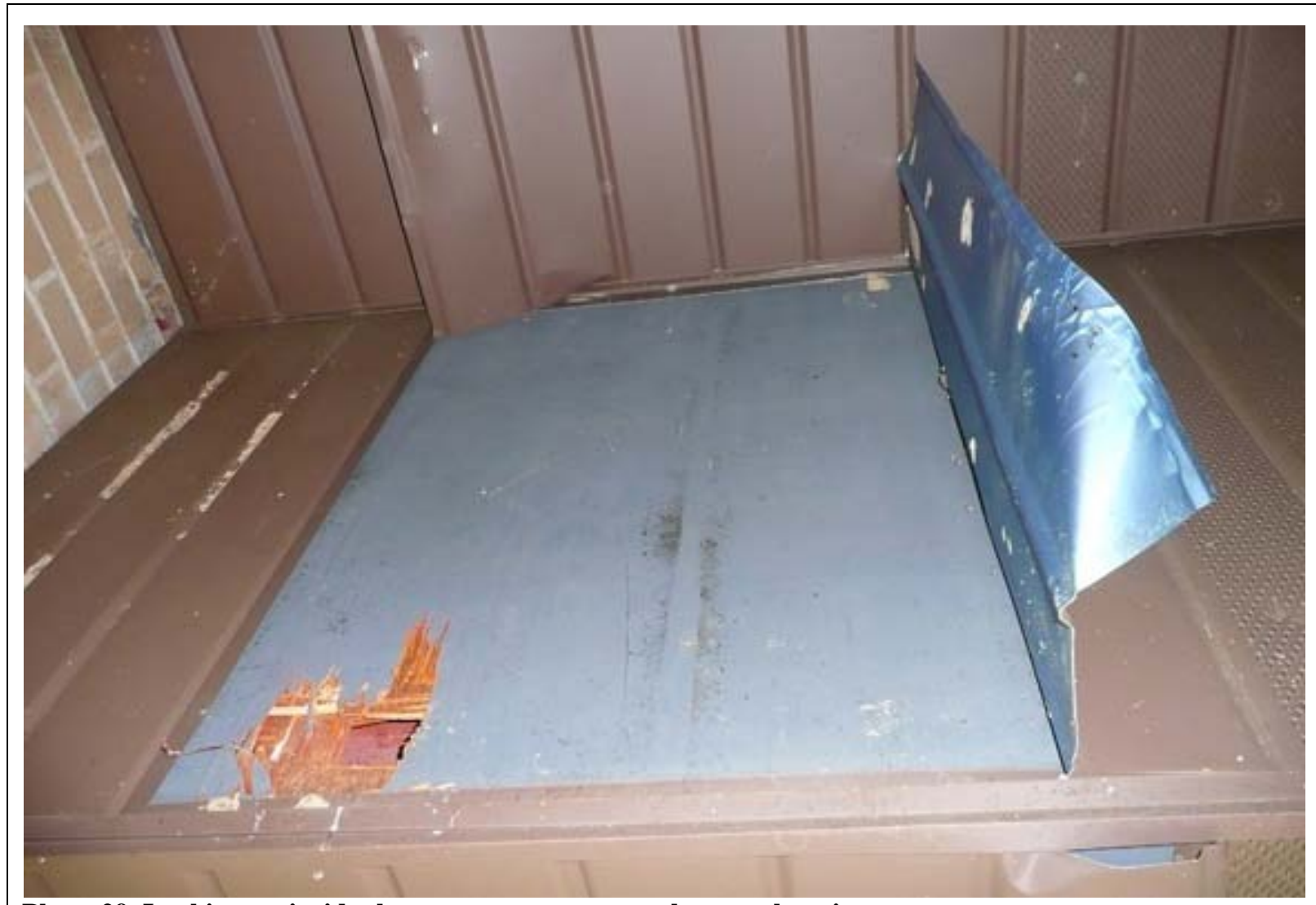

Photo 29. L ooking up inside the canopy structure on the east elevation.

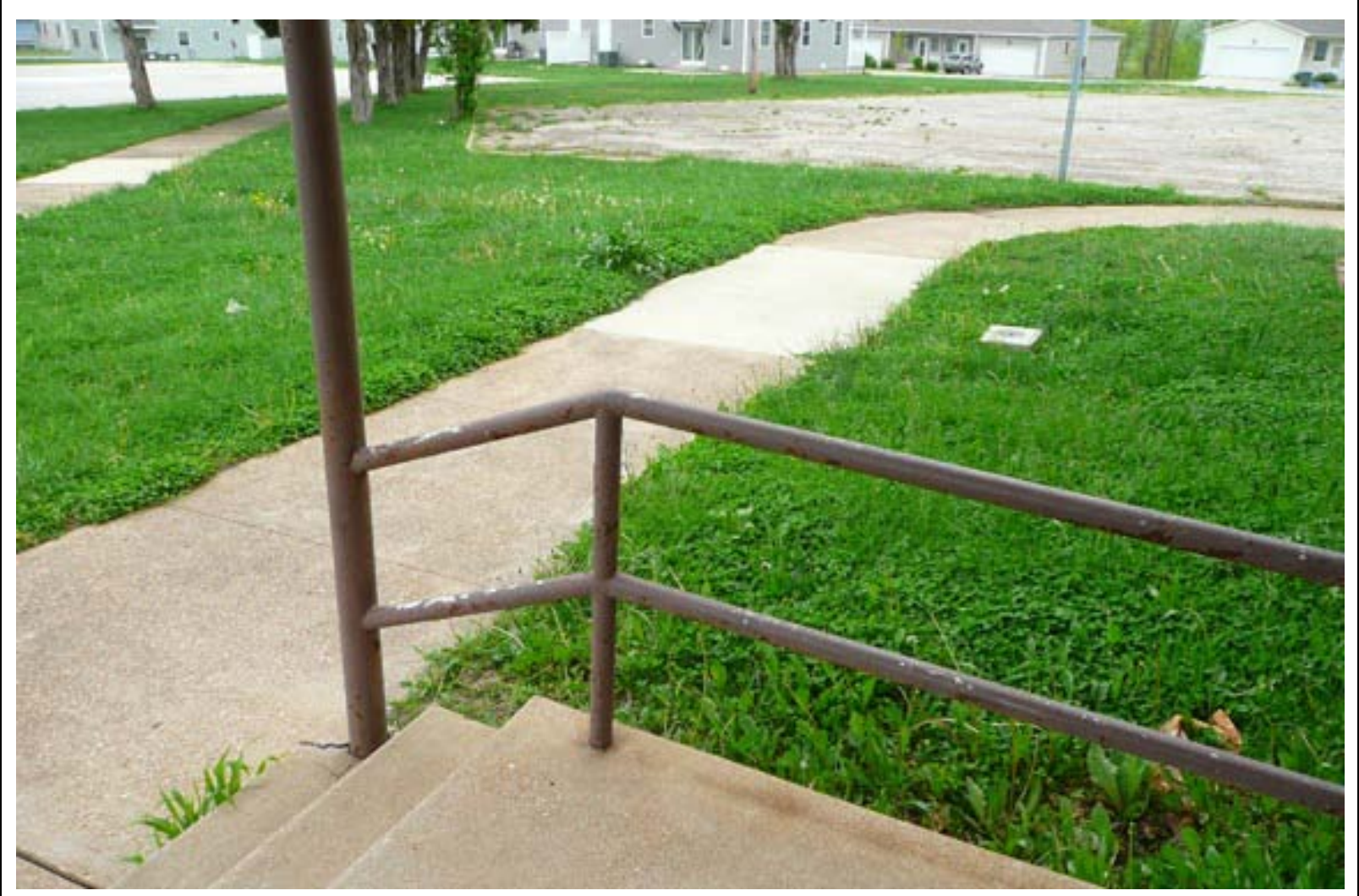

Photo 30. C lose-up of railings near the east entry. 


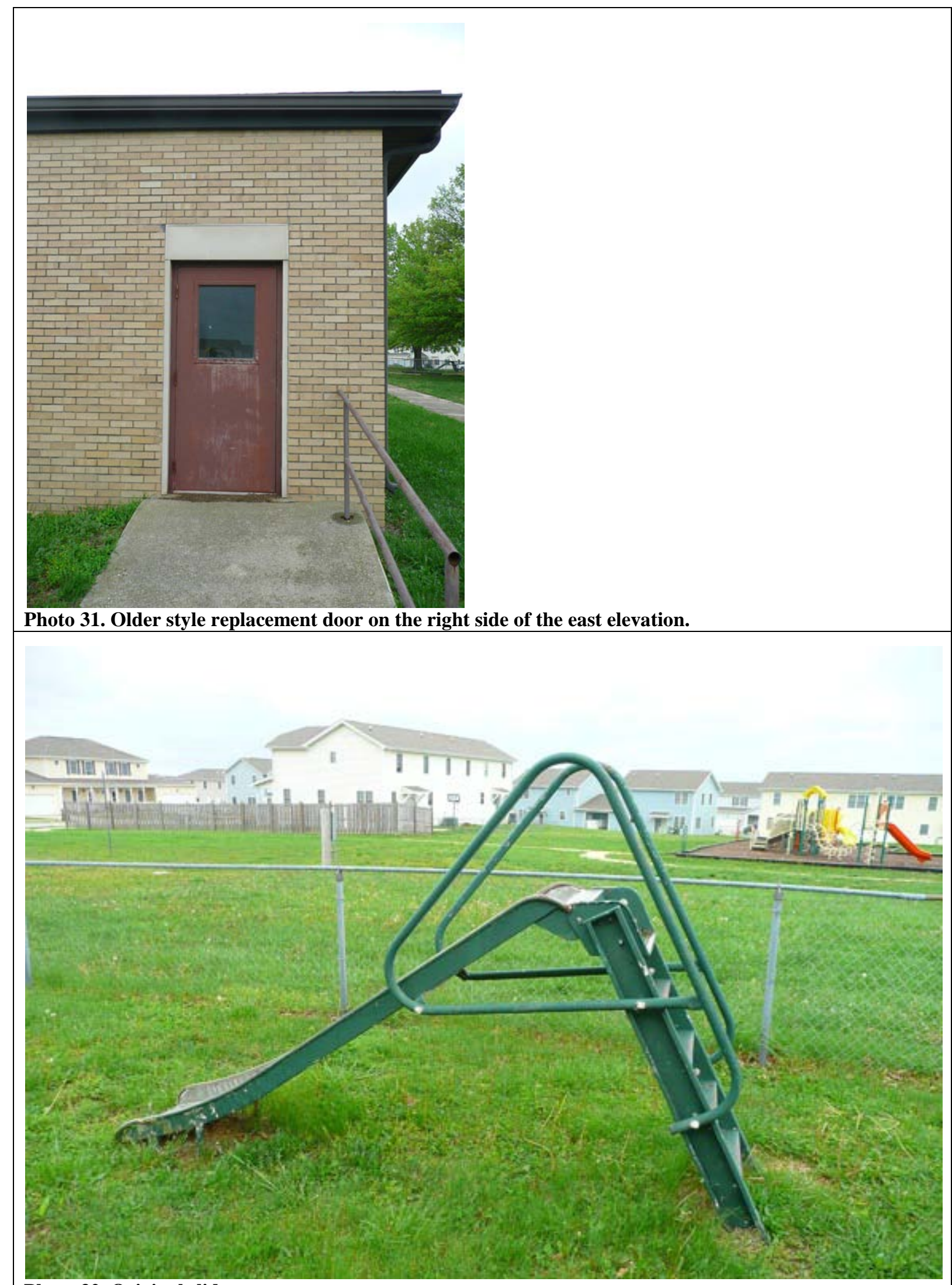

Photo 32. Original slide. 


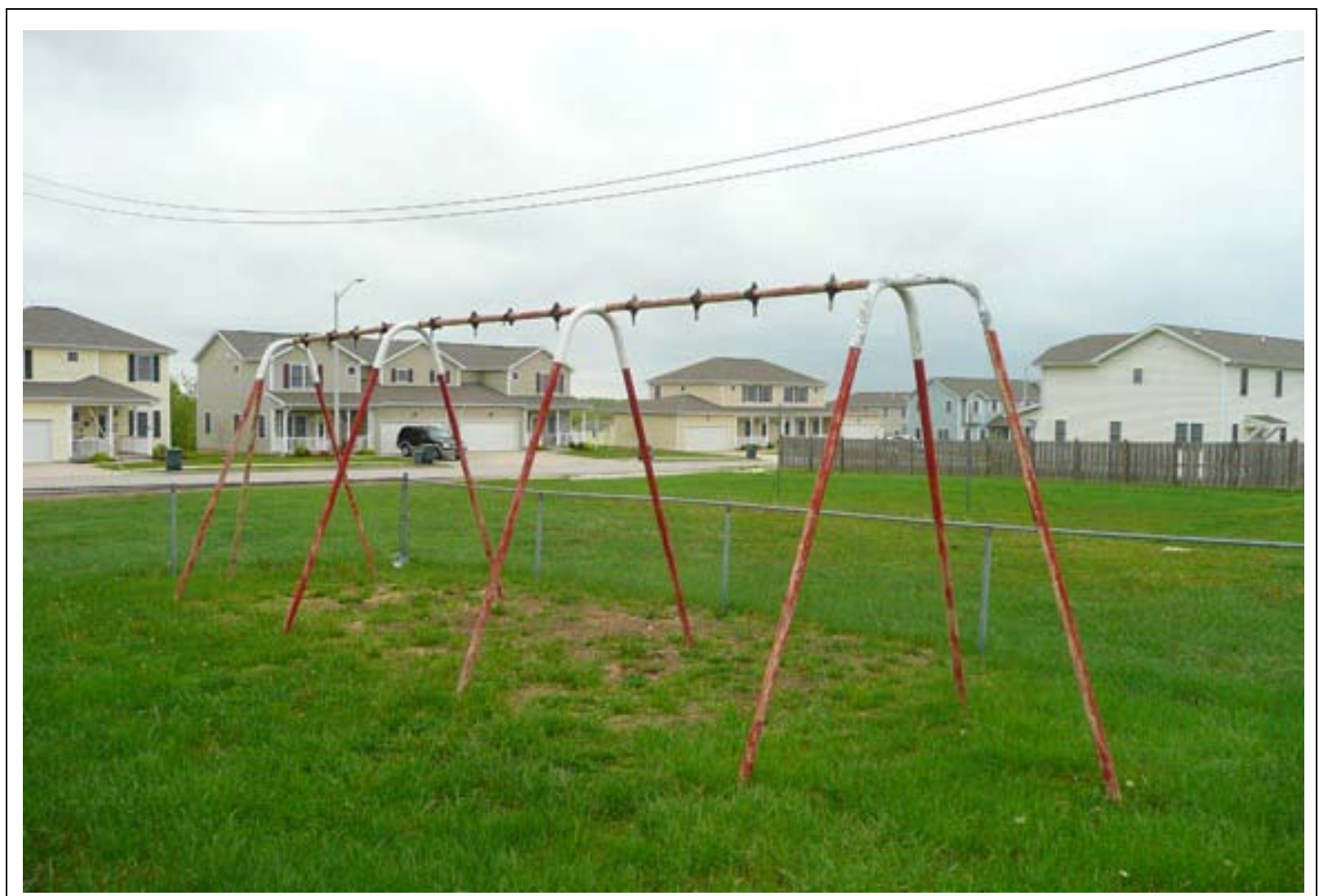

Photo 33. Original swingset.

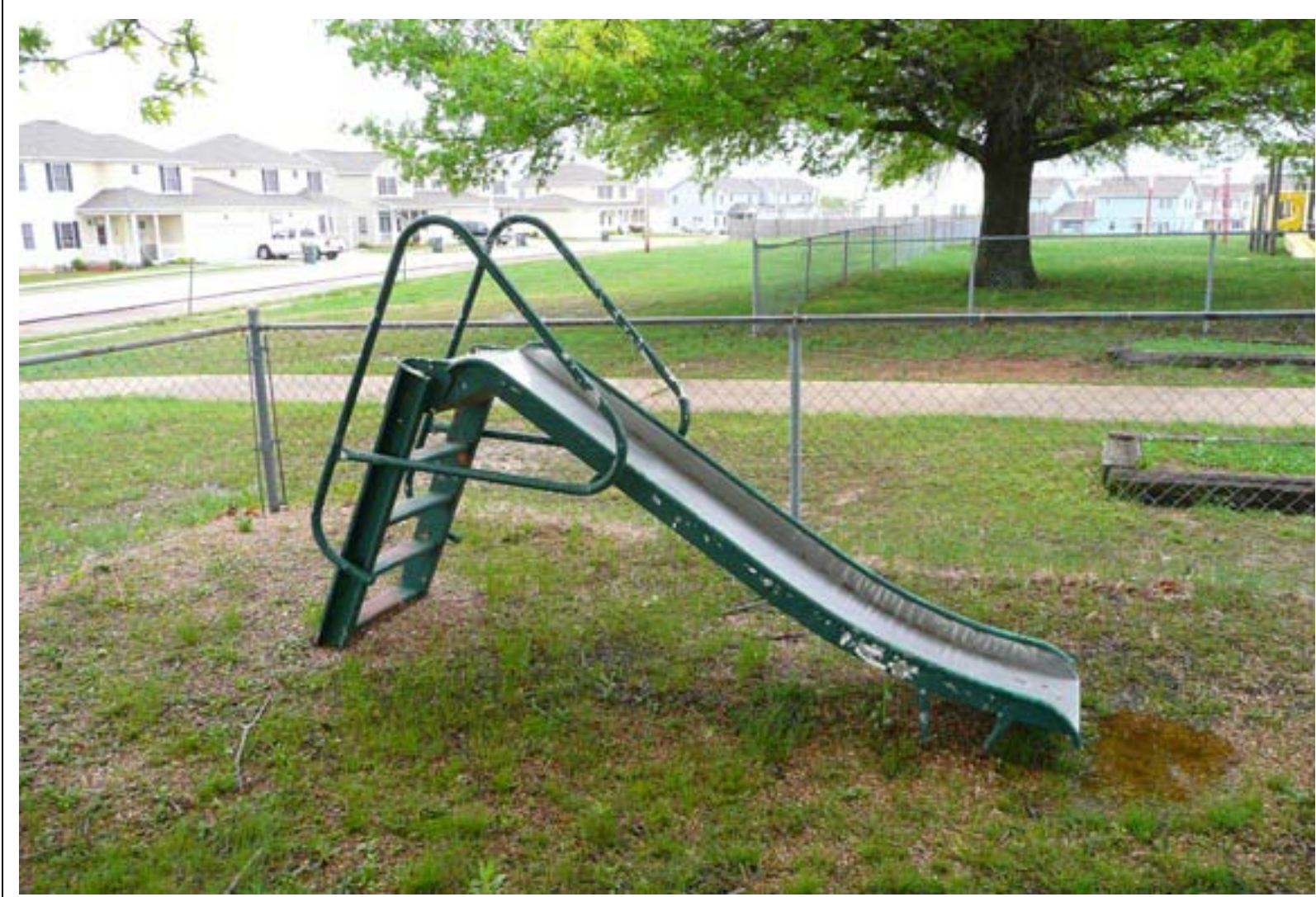

Photo 34. Original slide. 


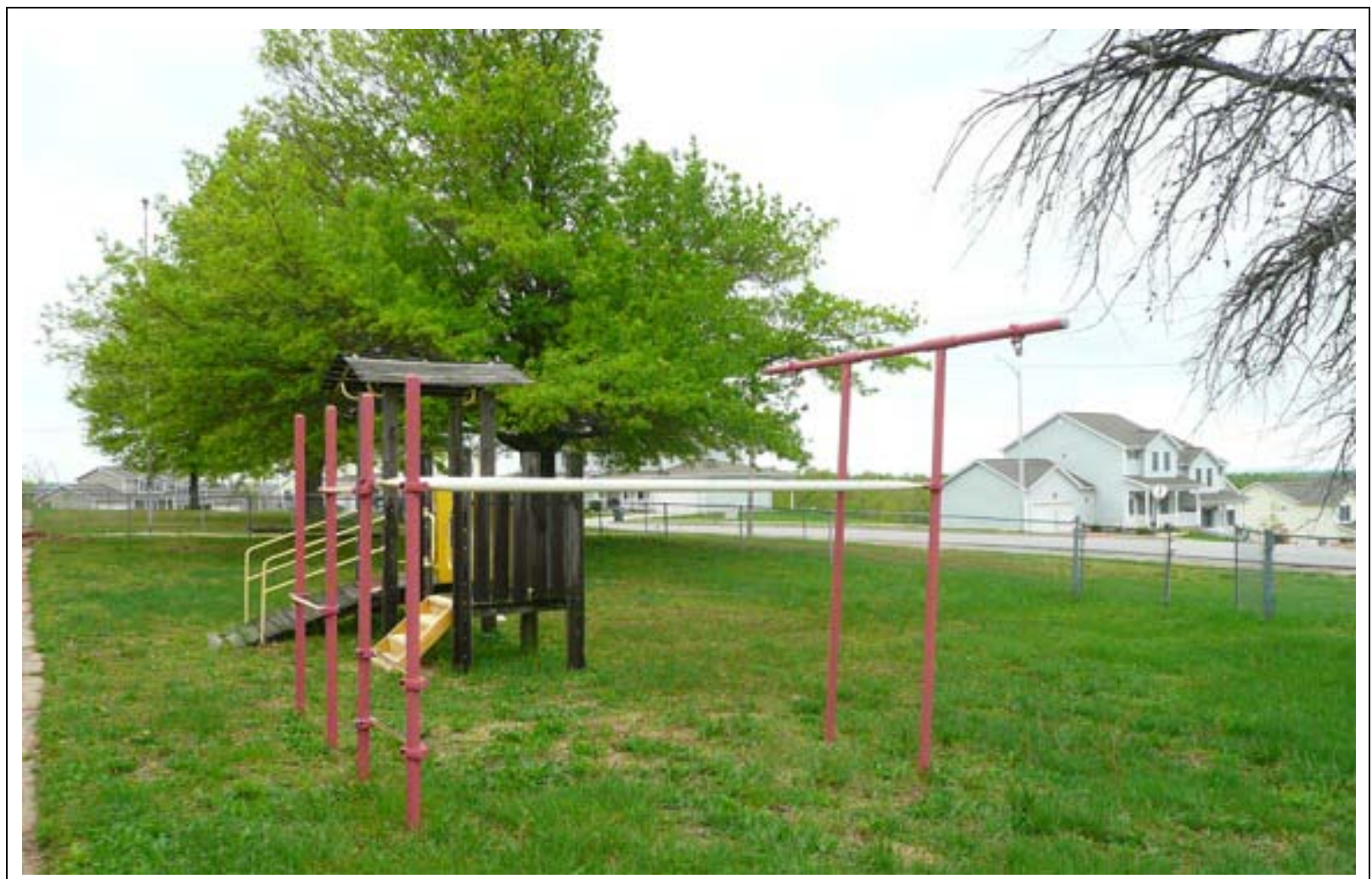

Photo 35. Original jungle gym in foreground with newer version in the background.

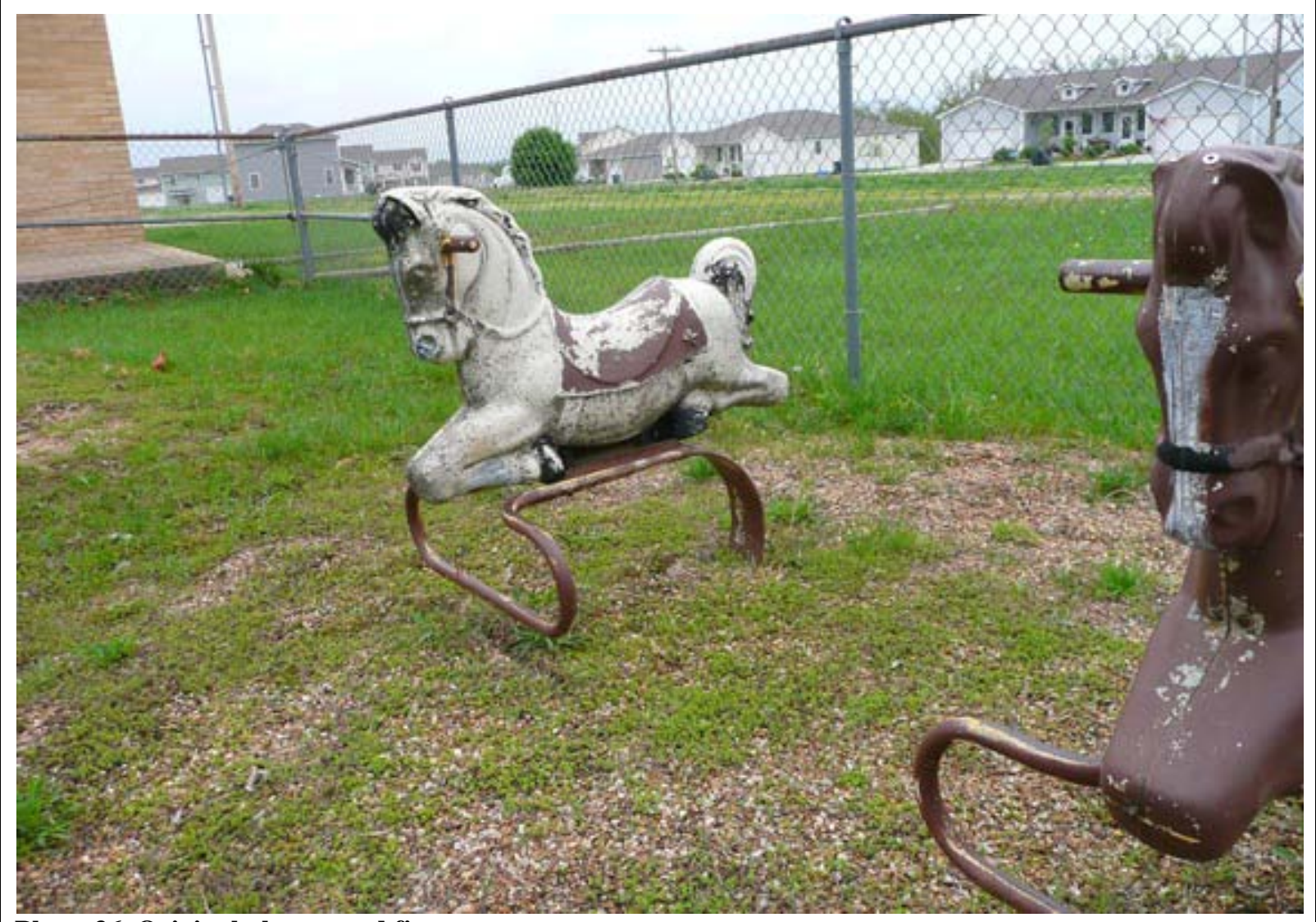

Photo 36. Original playground fixtures. 


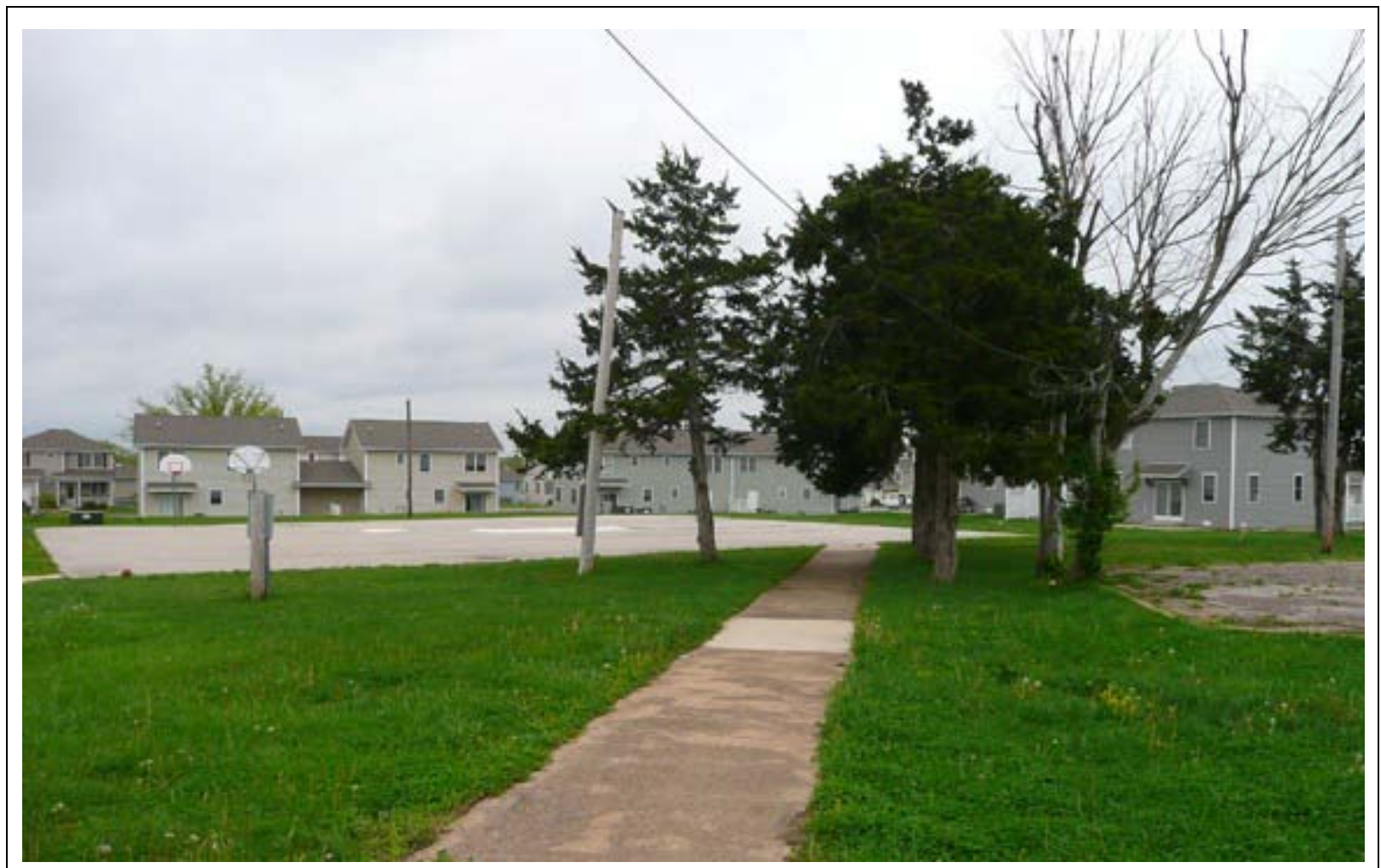

Photo 37. L ooking north toward nearby houses located in the E agle Point neighborhood that surrounds the school.

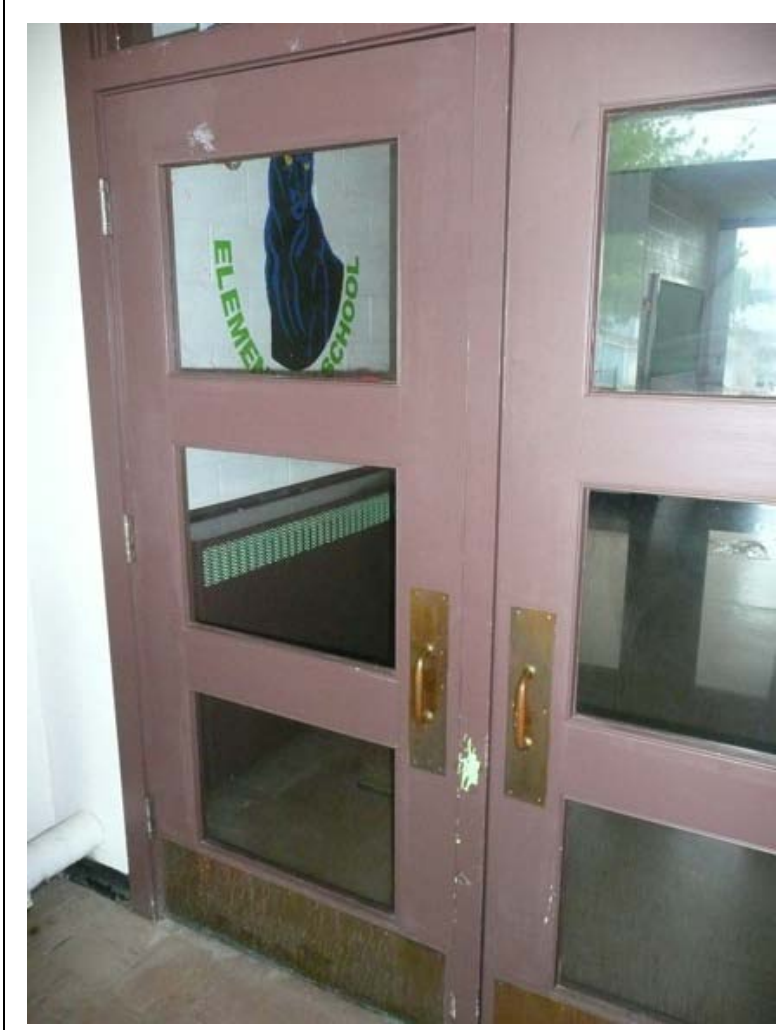

Photo 38. Original vestibule entry doors located near the north entry. 


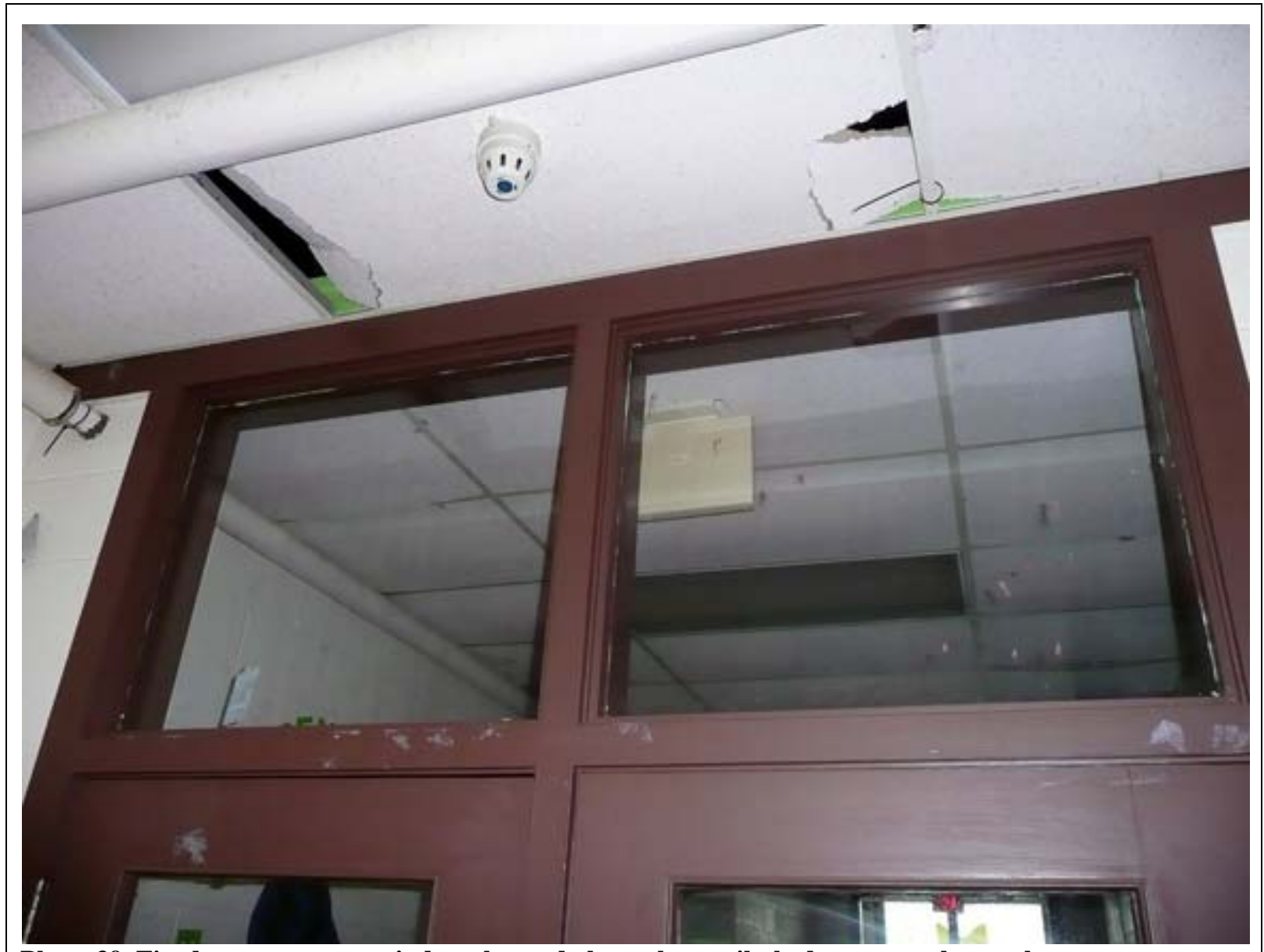

Photo 39. Fixed-pane transom windows located above the vestibule doors near the north entry.

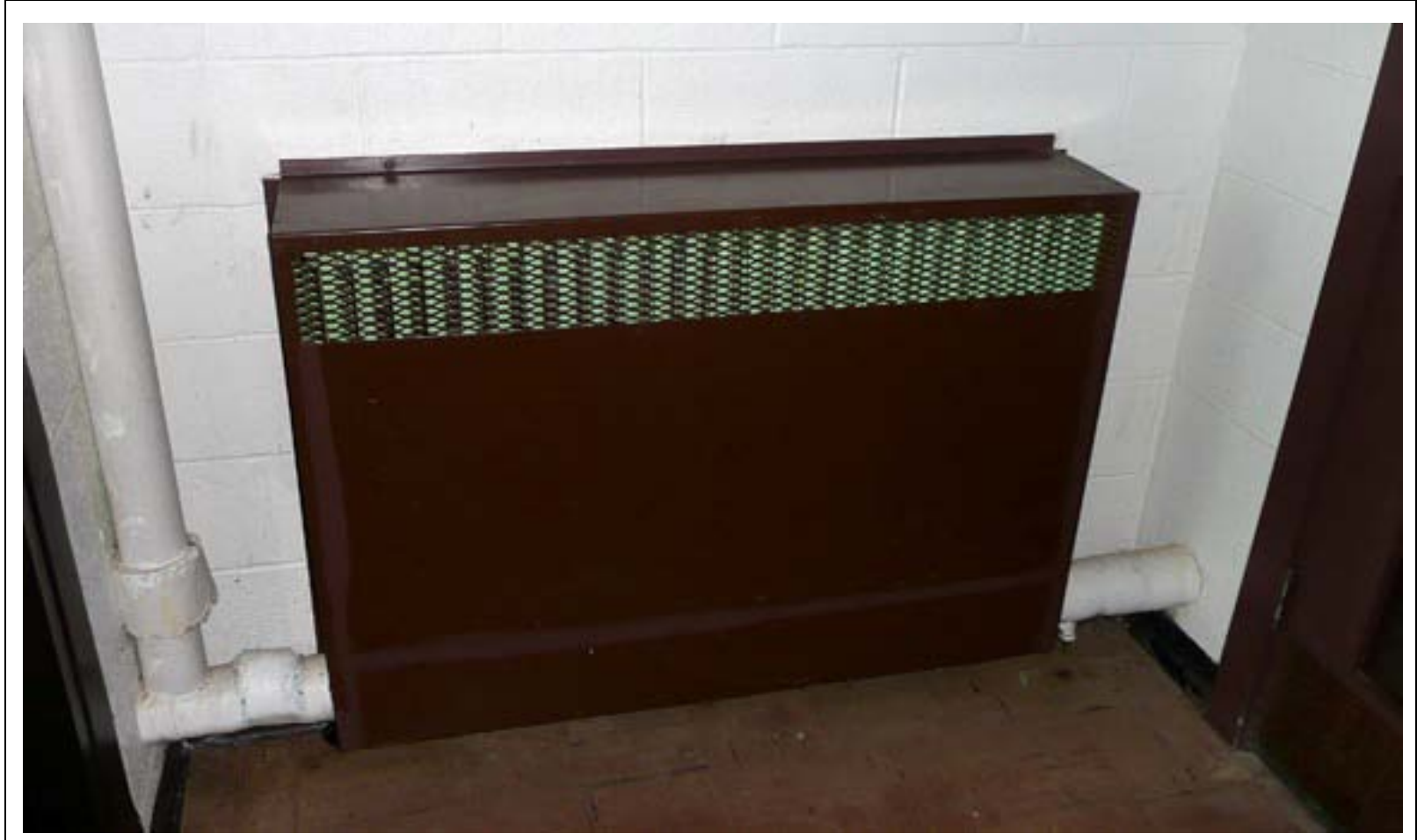

Photo 40. Radiator cover located in the vestibule. 


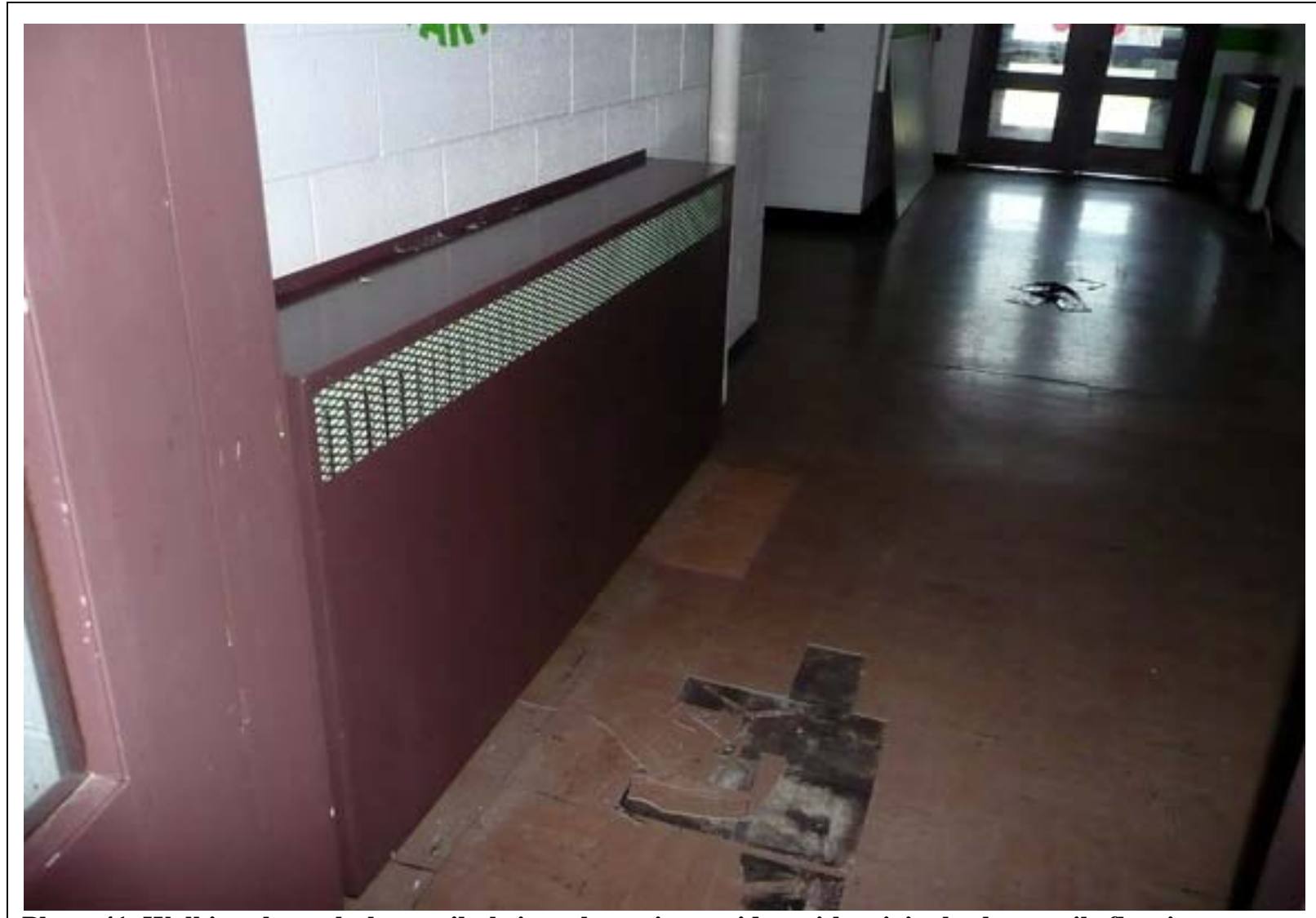

Photo 41. Walking through the vestibule into the main corridor with original asbestos tile flooring.

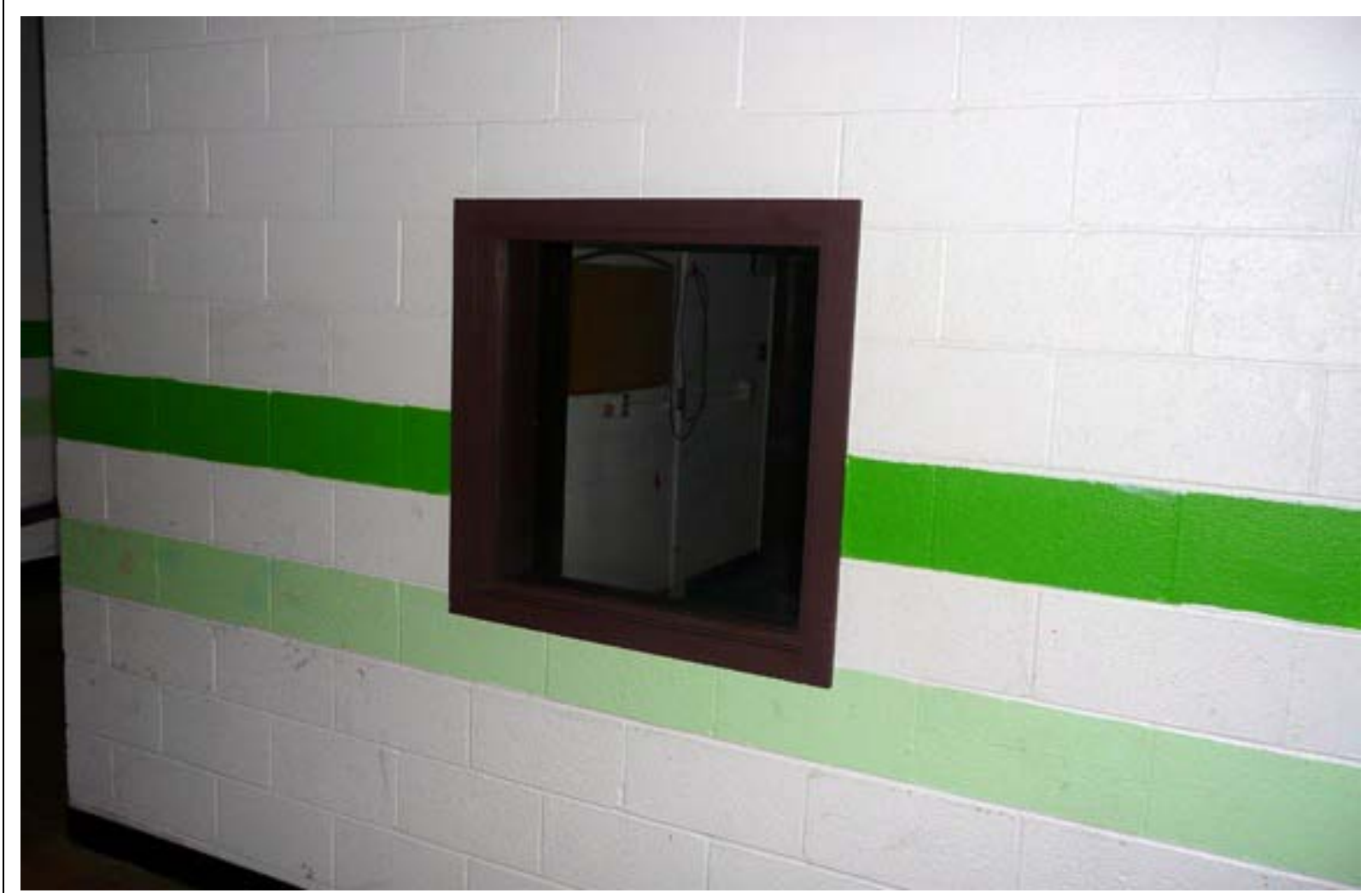




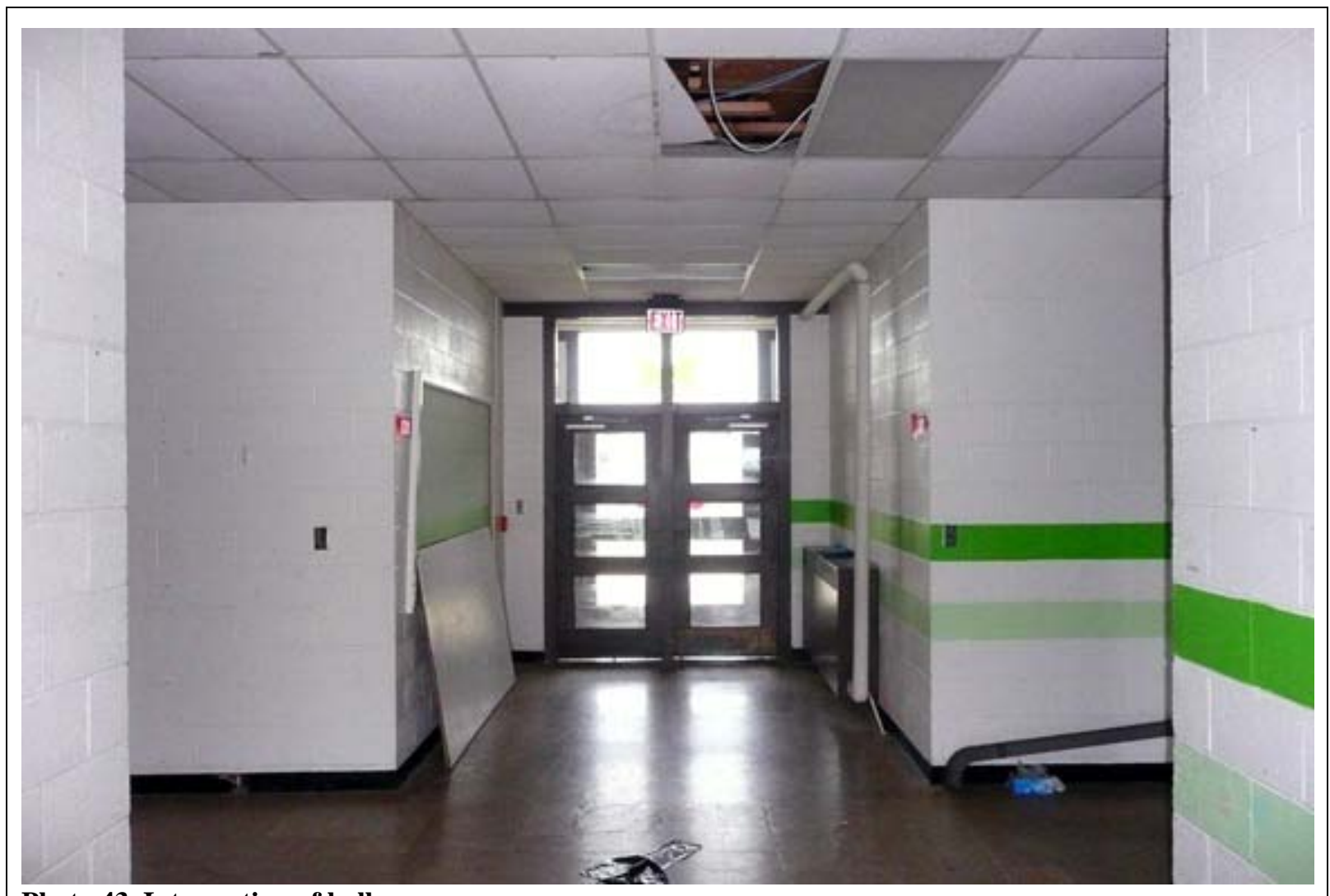

Photo 43. Inter section of hallways.

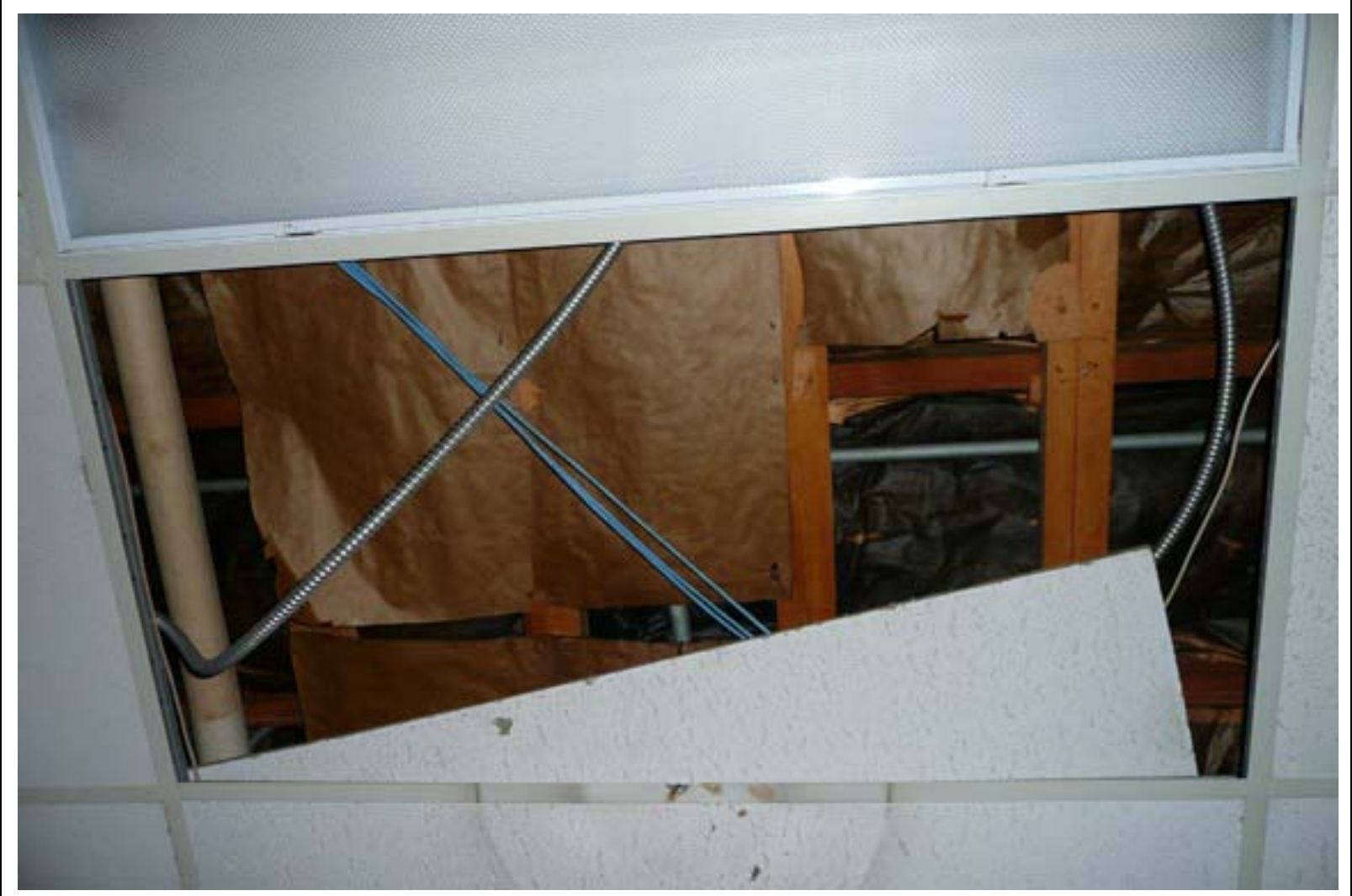

Photo 44. L ooking up into the acoustical tile ceiling near the interection of the hallways. 


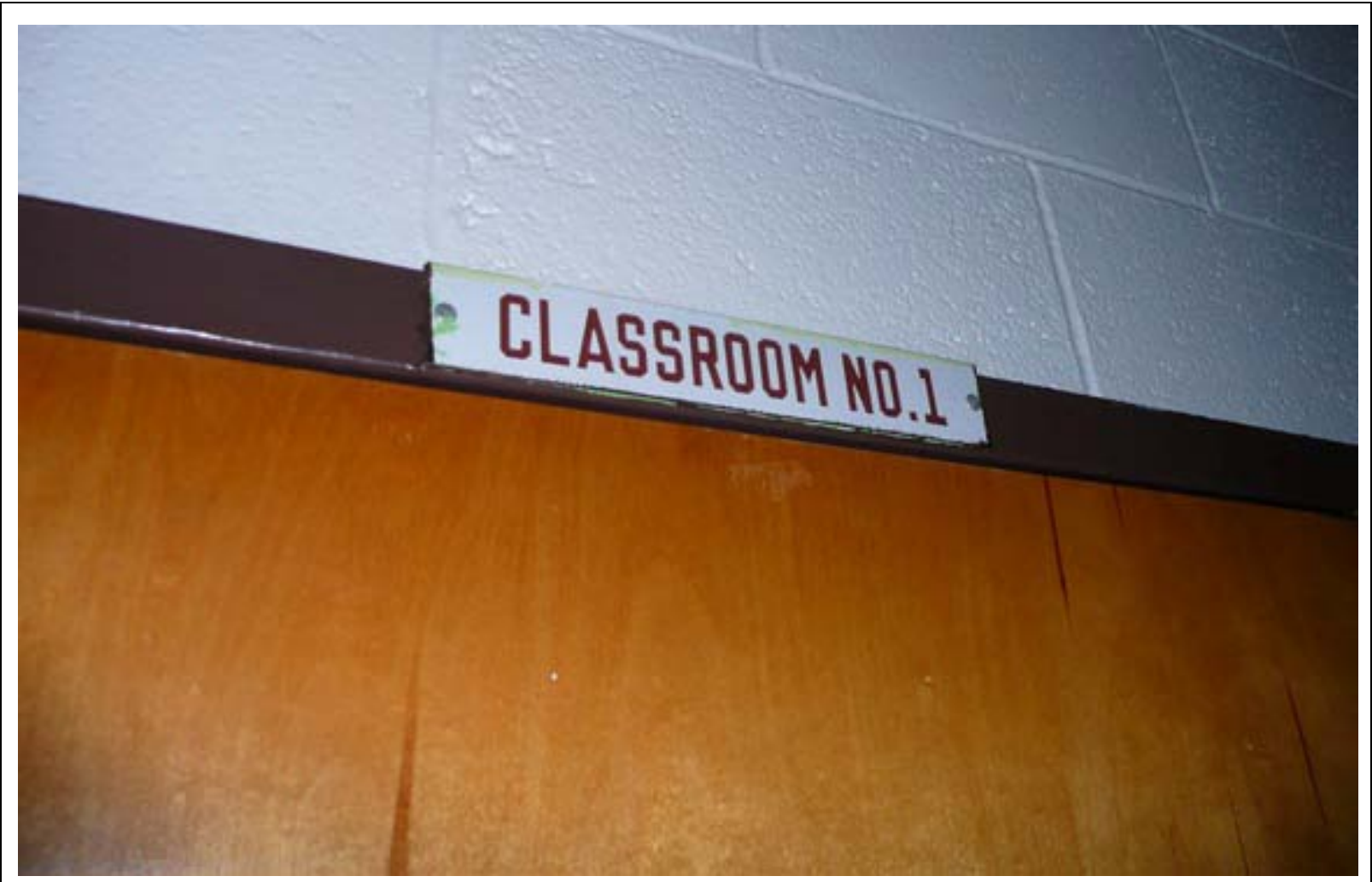

Photo 45. Original Classroom No. 1 sign.

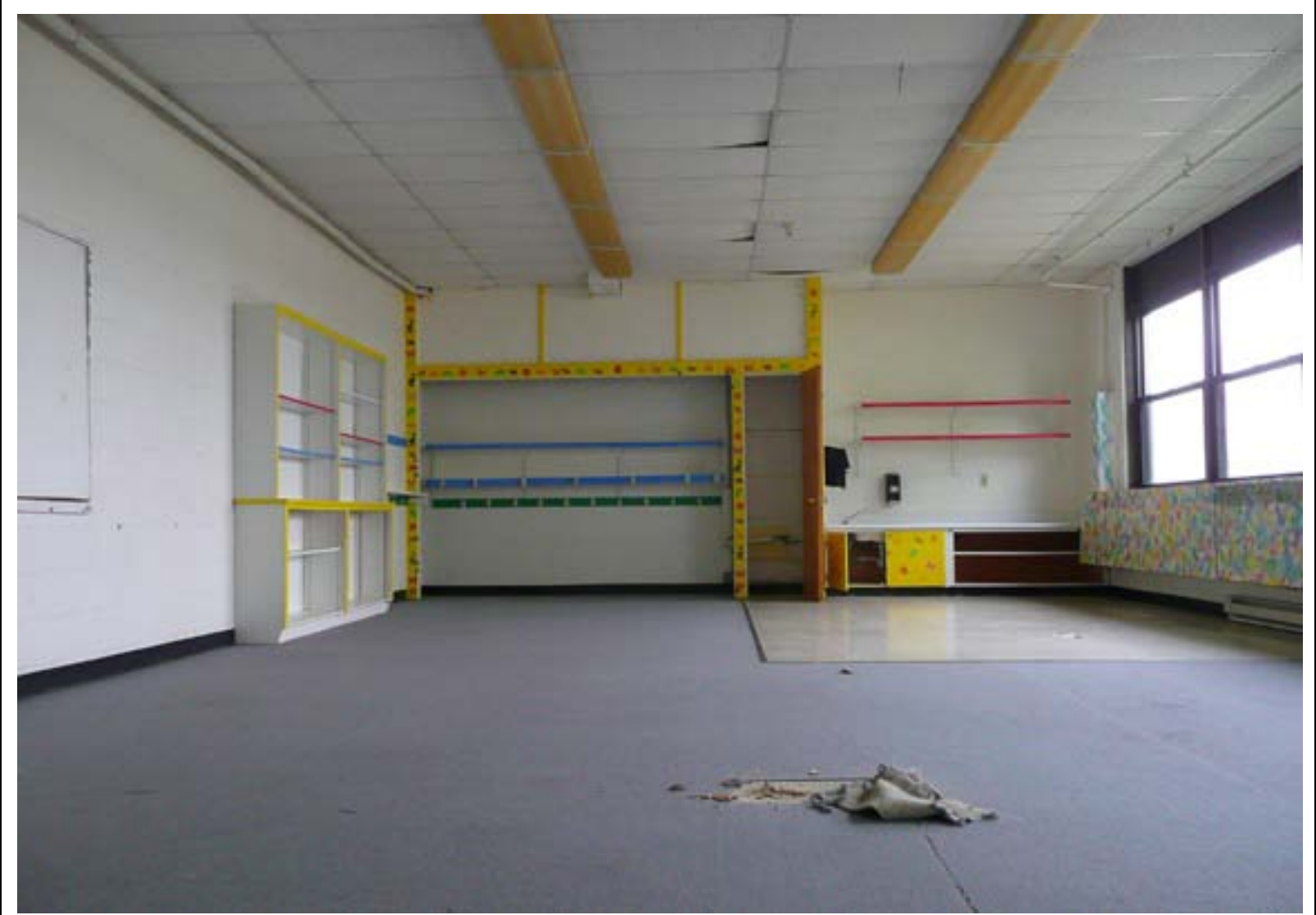

Photo 46. Inteiror of Classroom No. 1. 


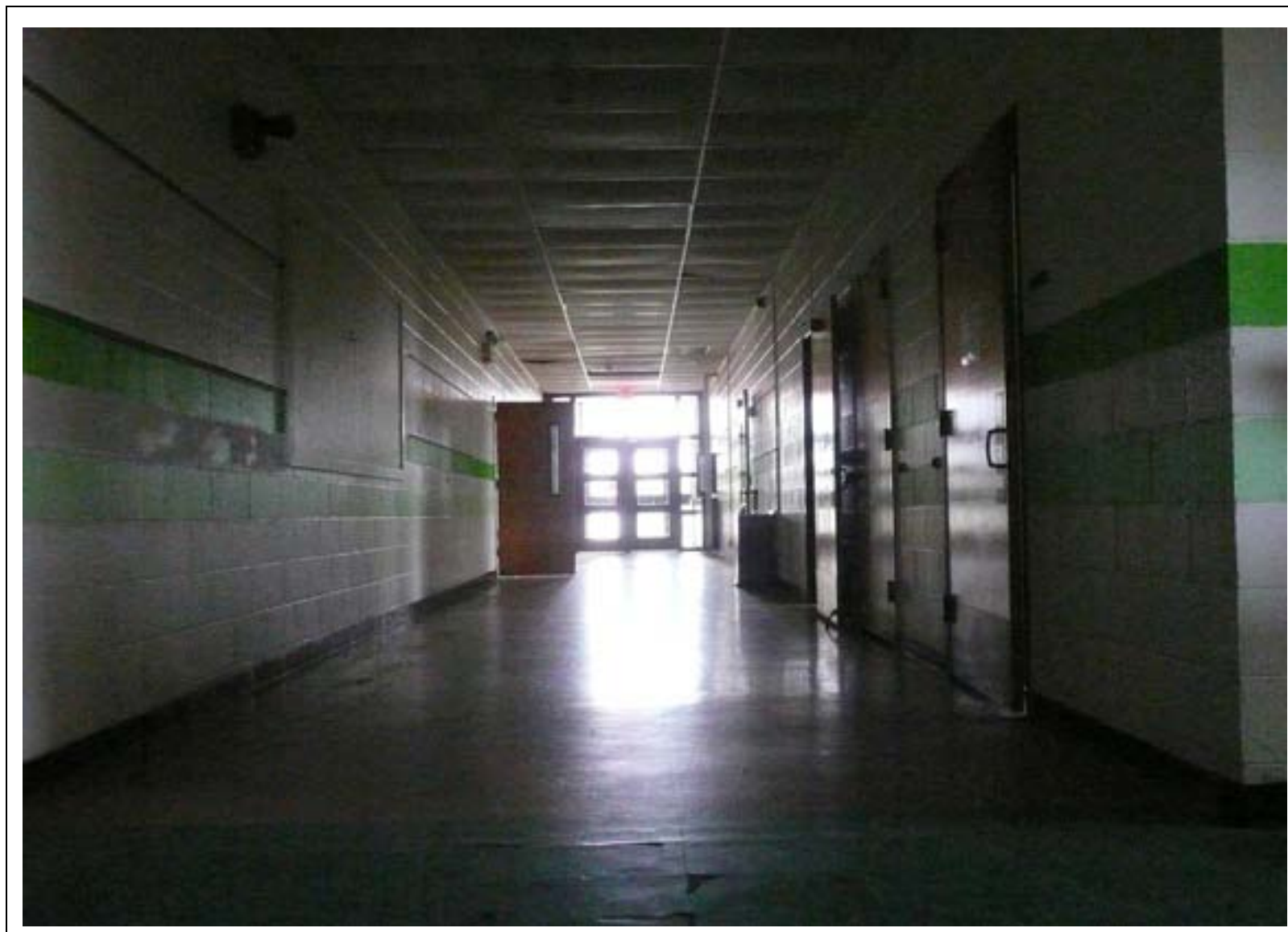

Photo 47. L ooking east down the main corridor.

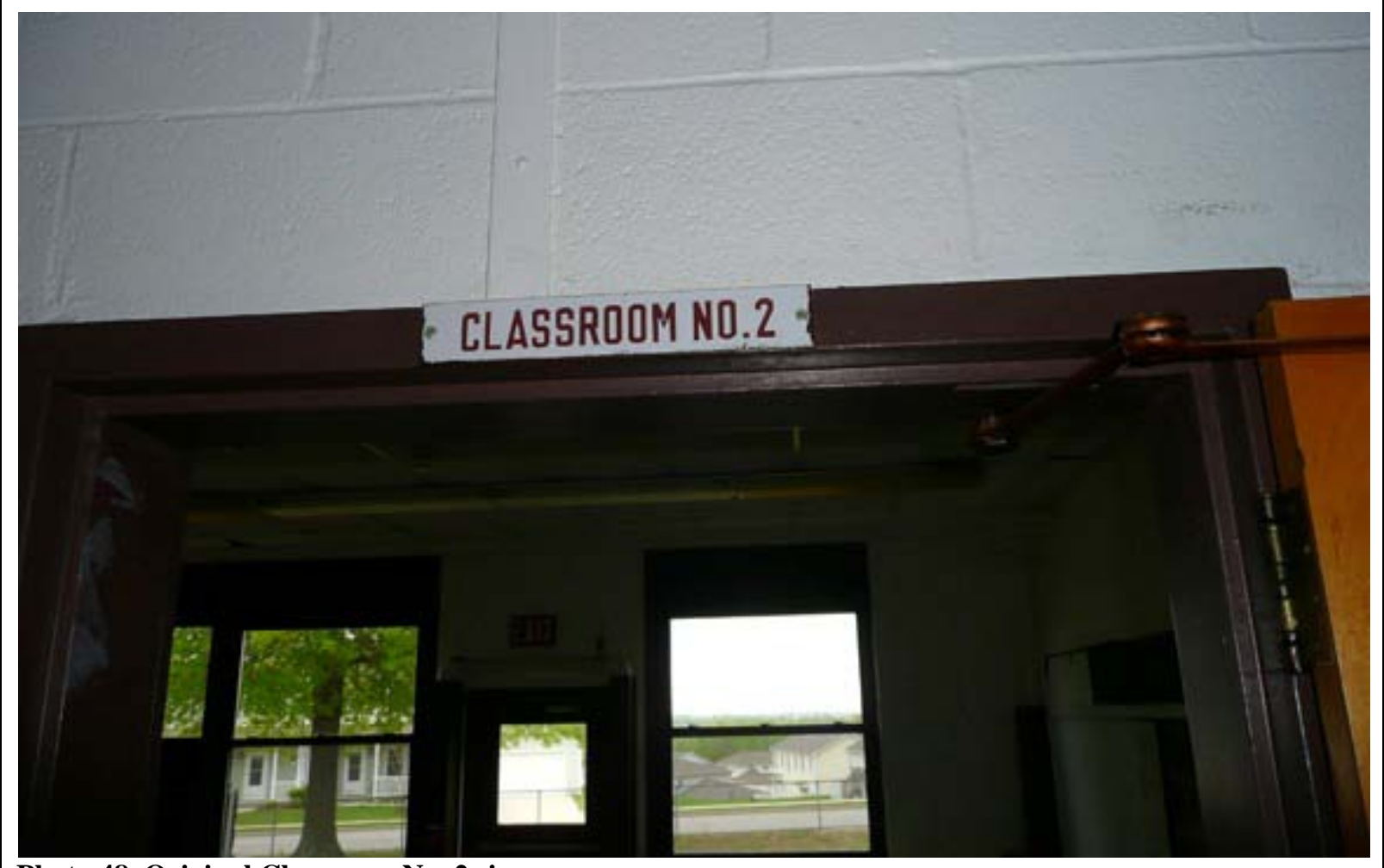

Photo 48. Original Classroom No. 2 sign. 


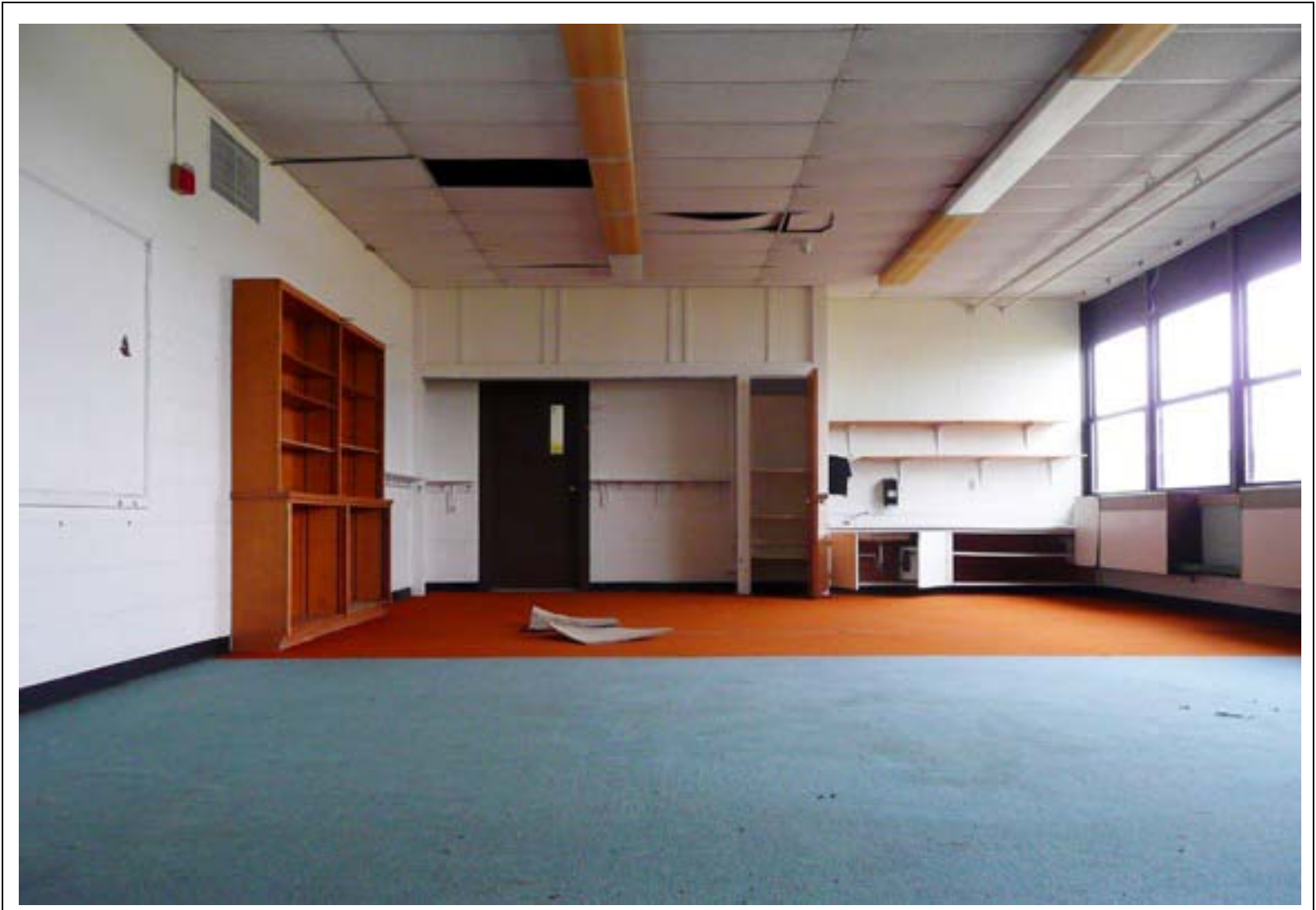

Photo 49. Interior of Classroom No. 2.

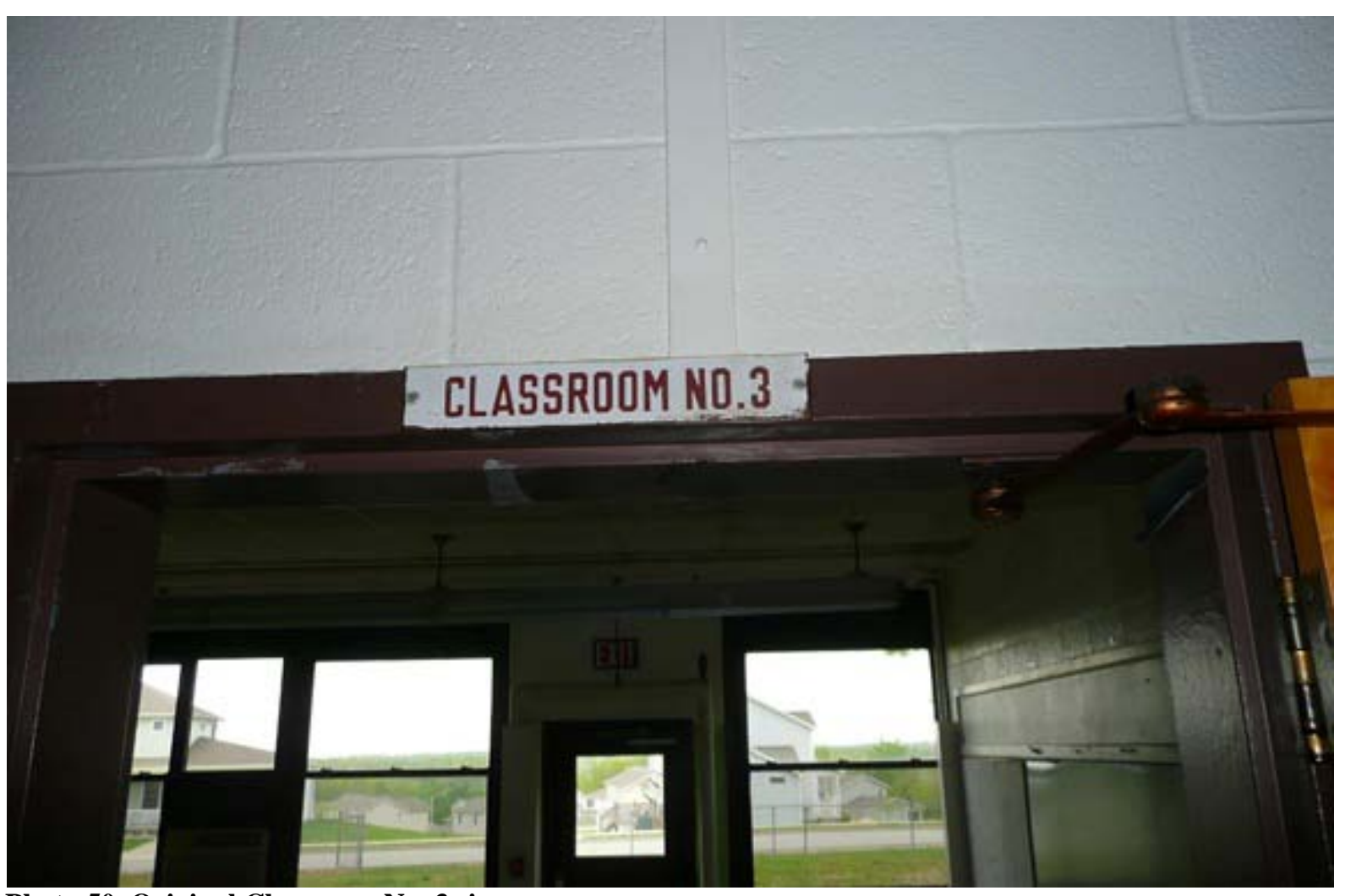




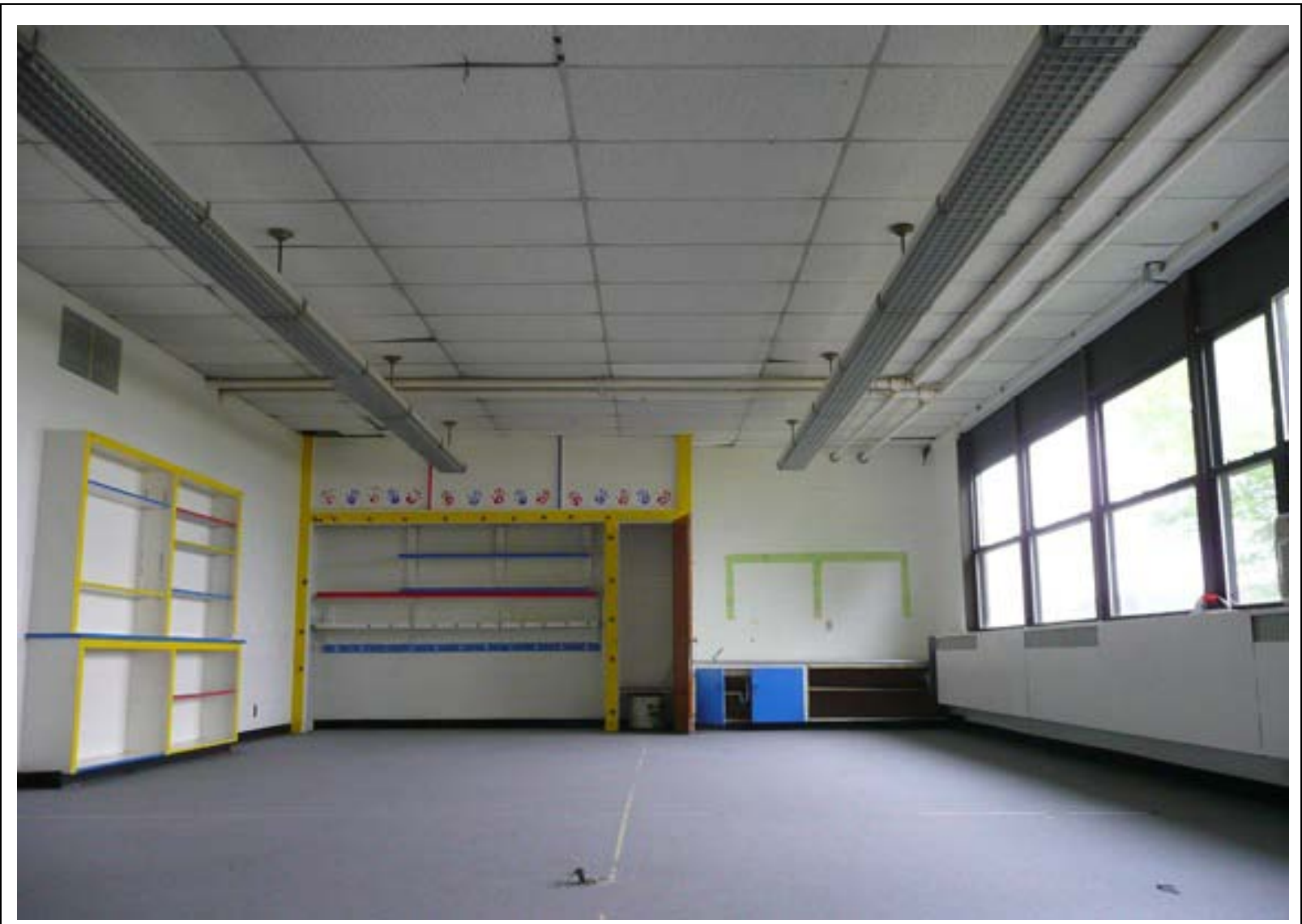

Photo 51. Interior of Classroom No. 3.

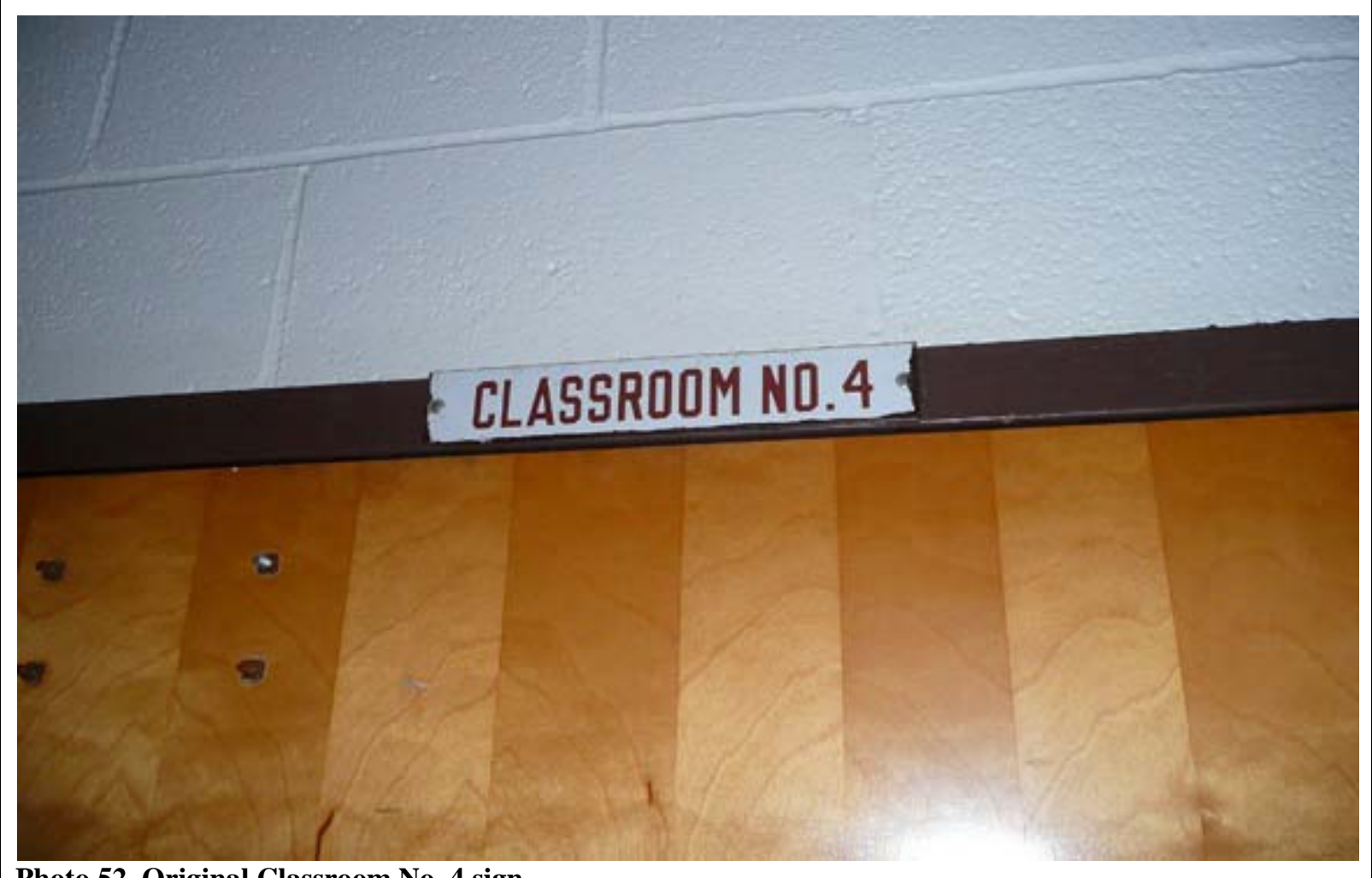

Photo 52. Original Classroom No. 4 sign. 


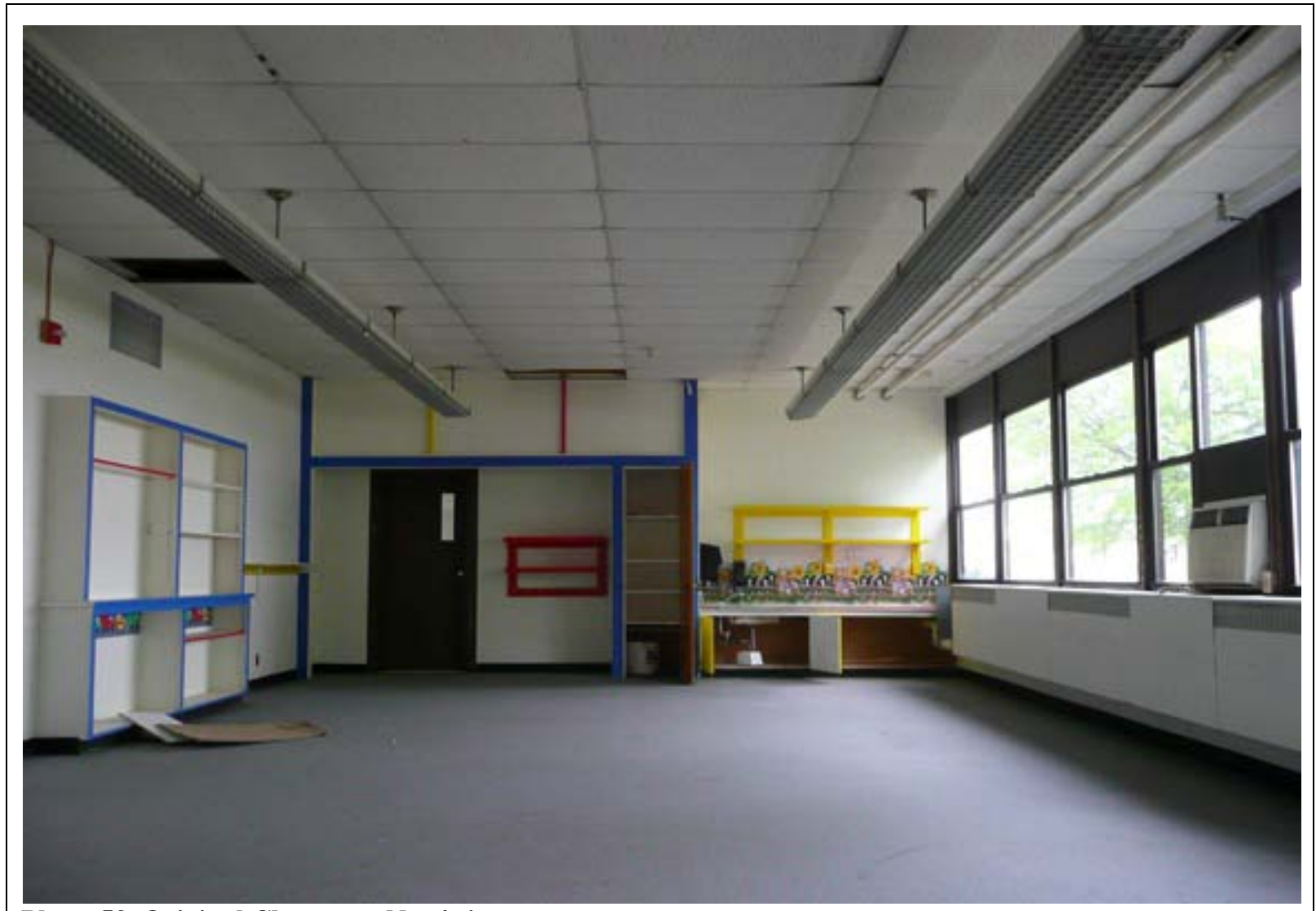

Photo 53. Original Classroom No. 4 sign.

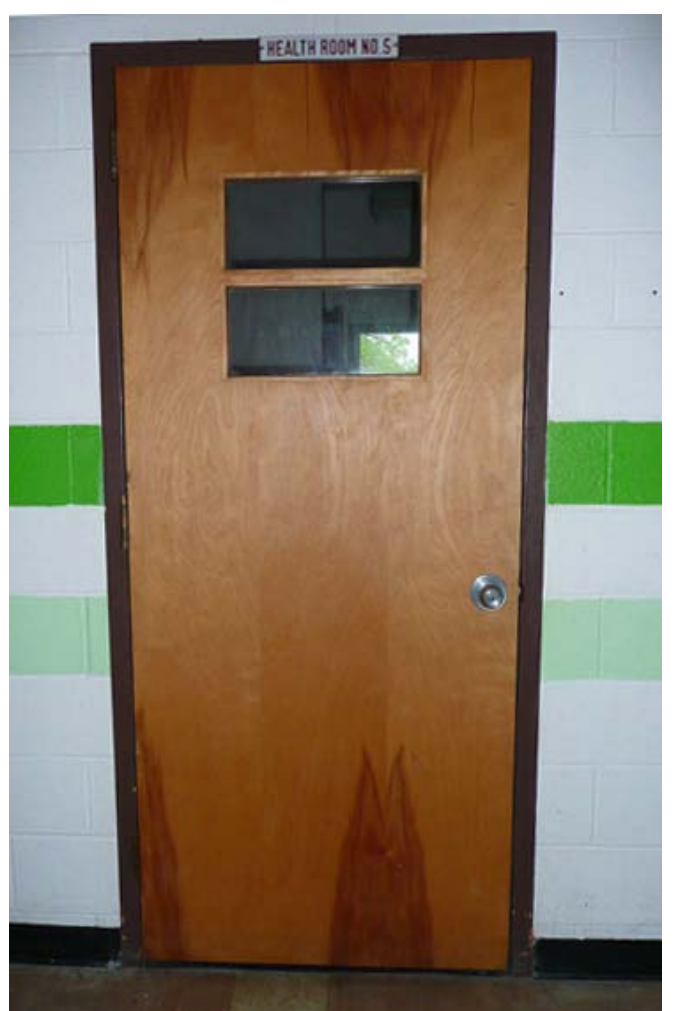

Photo 54. Health R oom No. 5 original door. 


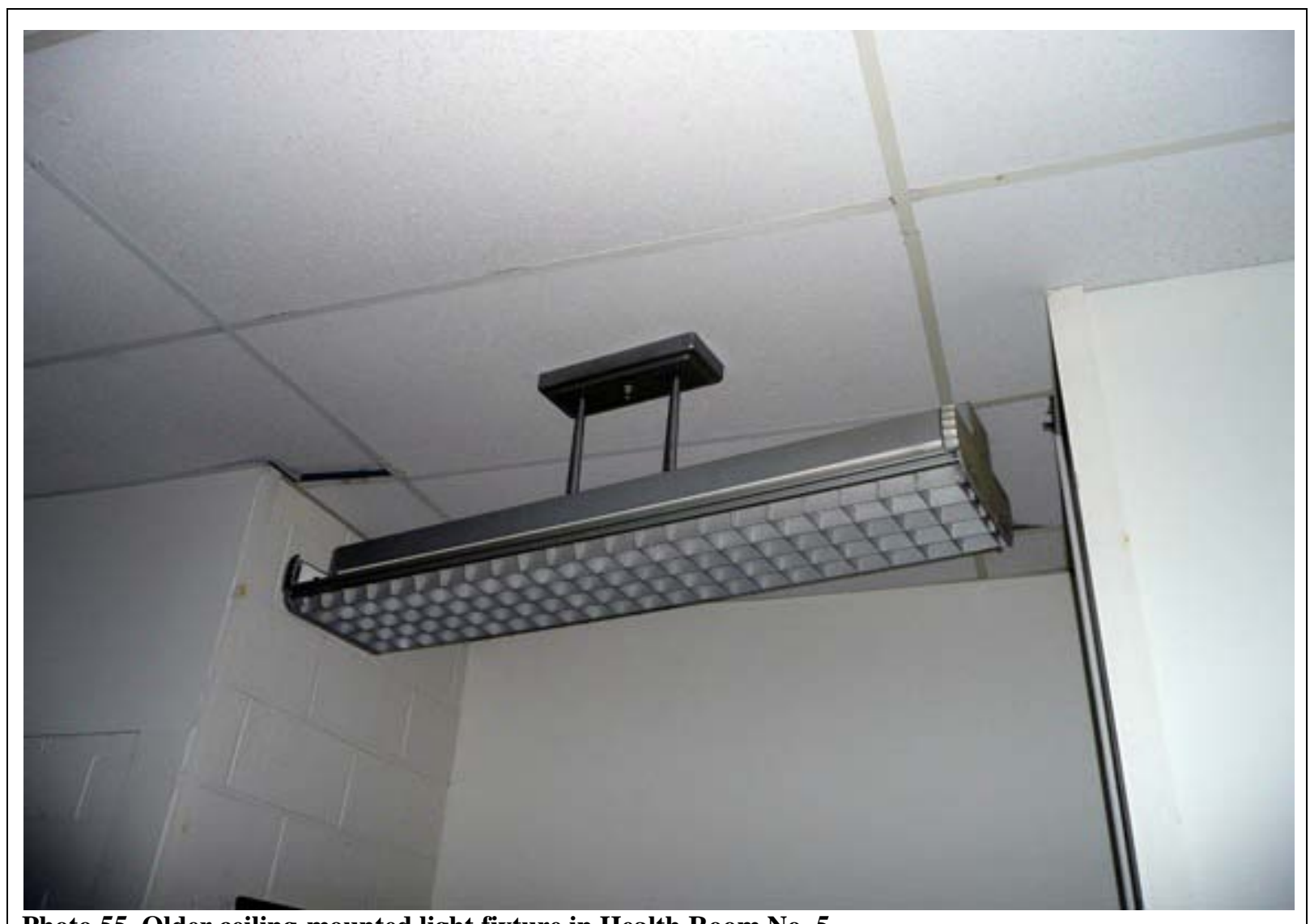

Photo 55. Older ceiling-mounted light fixture in Health R oom No. 5.

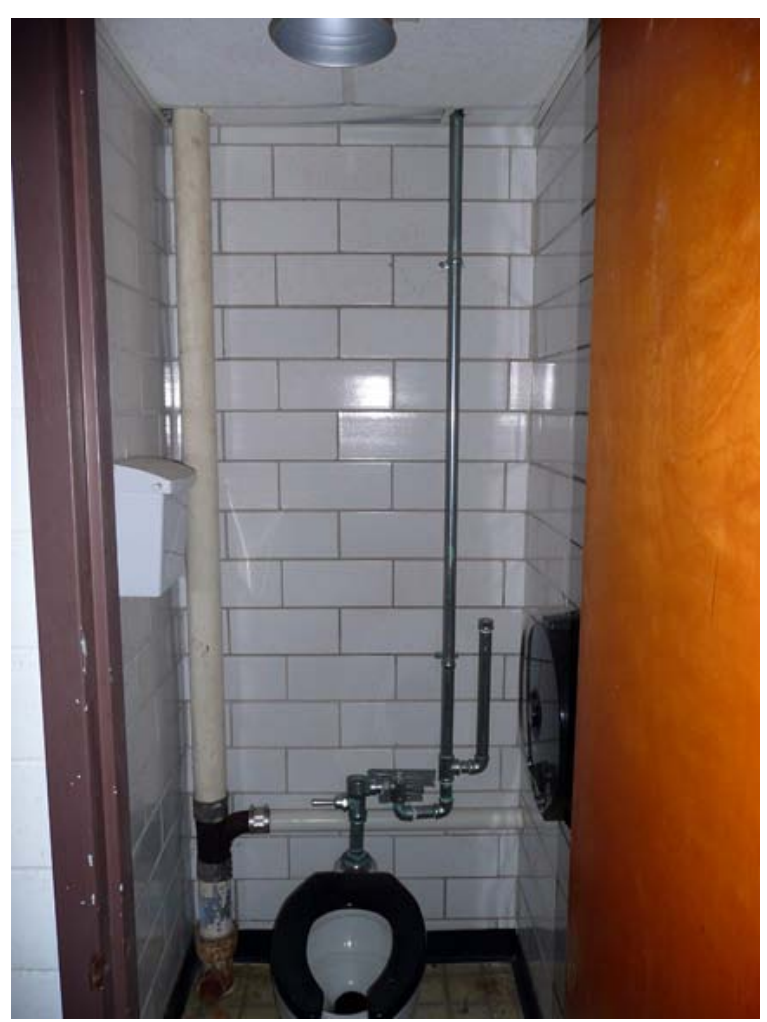

Photo 56. Original toilet room in Health R oom No. 5 showing glazed tile walls. 


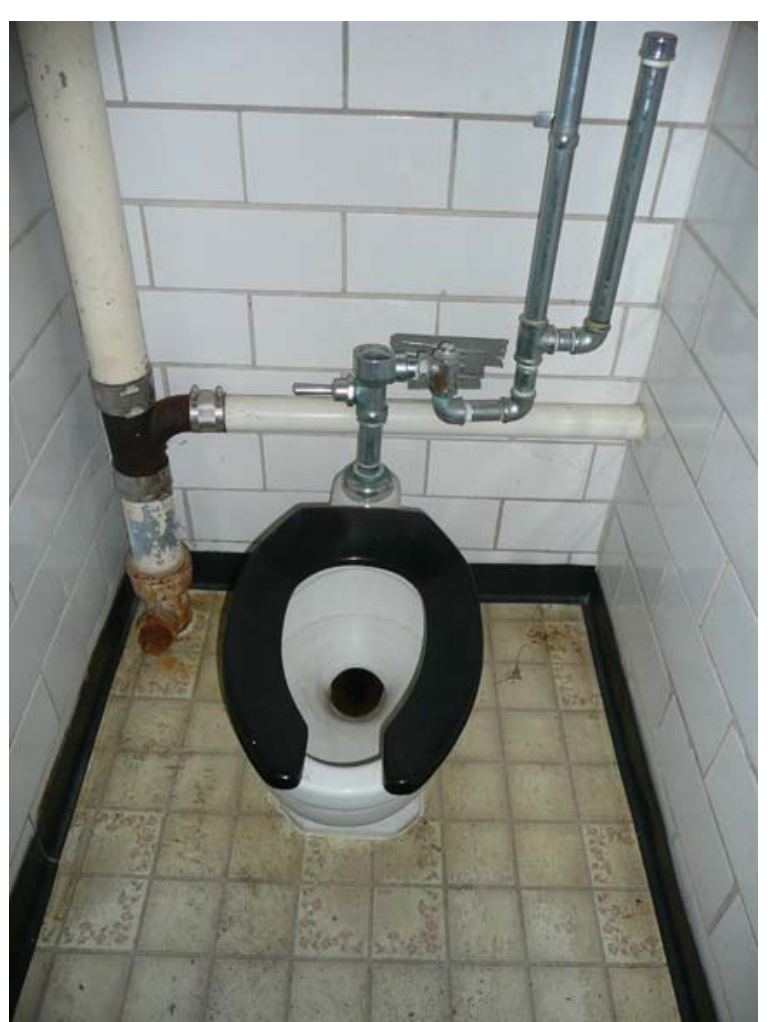

Photo 57. Original toilet in Health R oom No. 5.

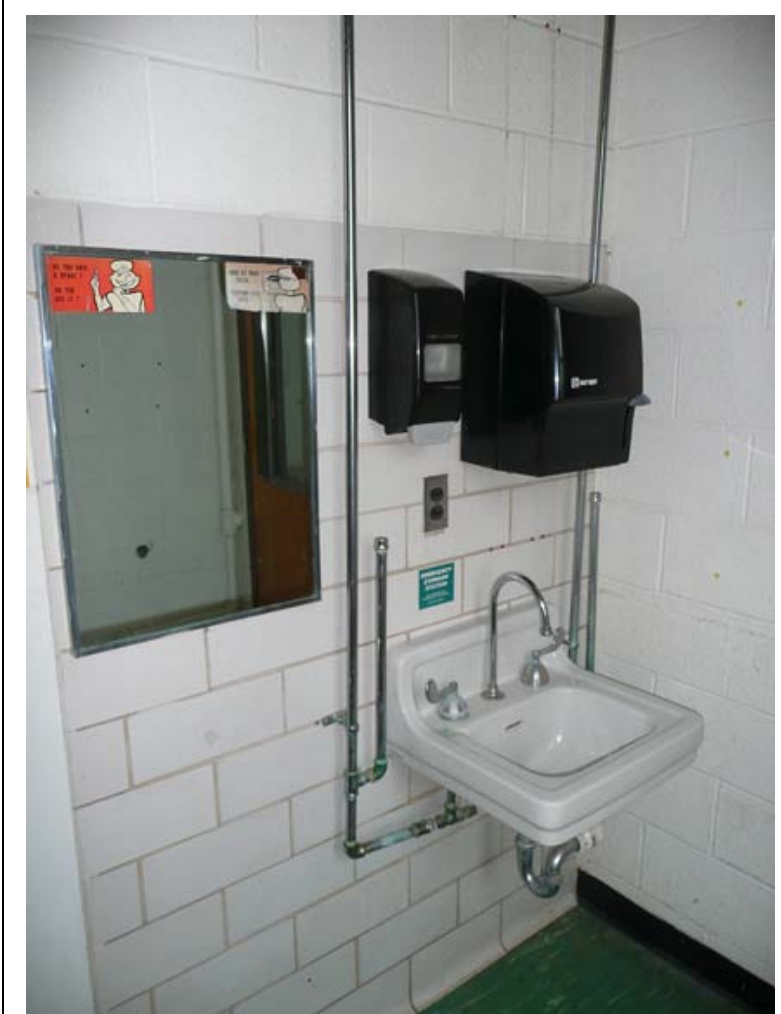

Photo 58. Original sink and glazed tile wall in Health Room No. 5. 


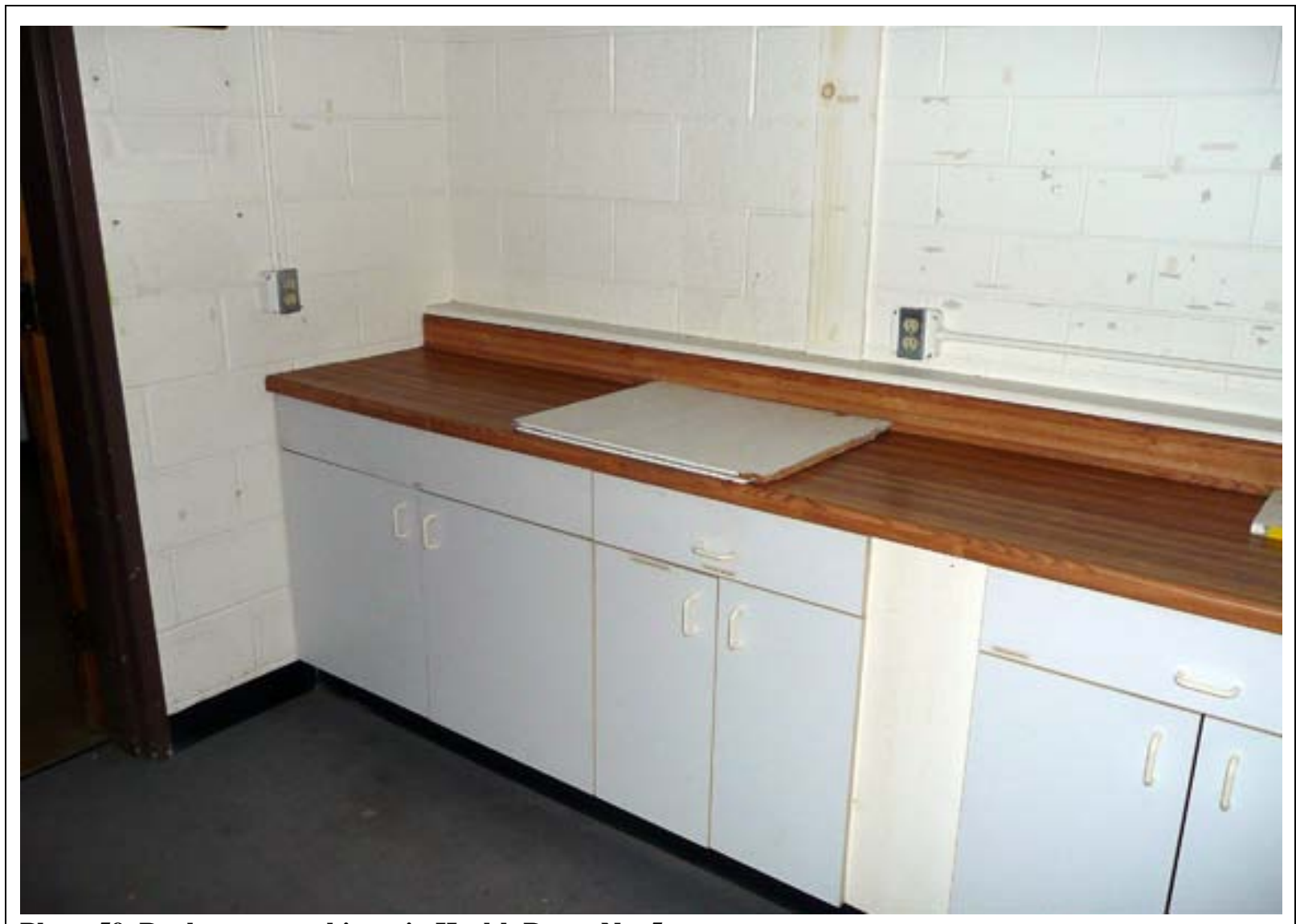

Photo 59. R eplacement cabinets in Health R oom No. 5.

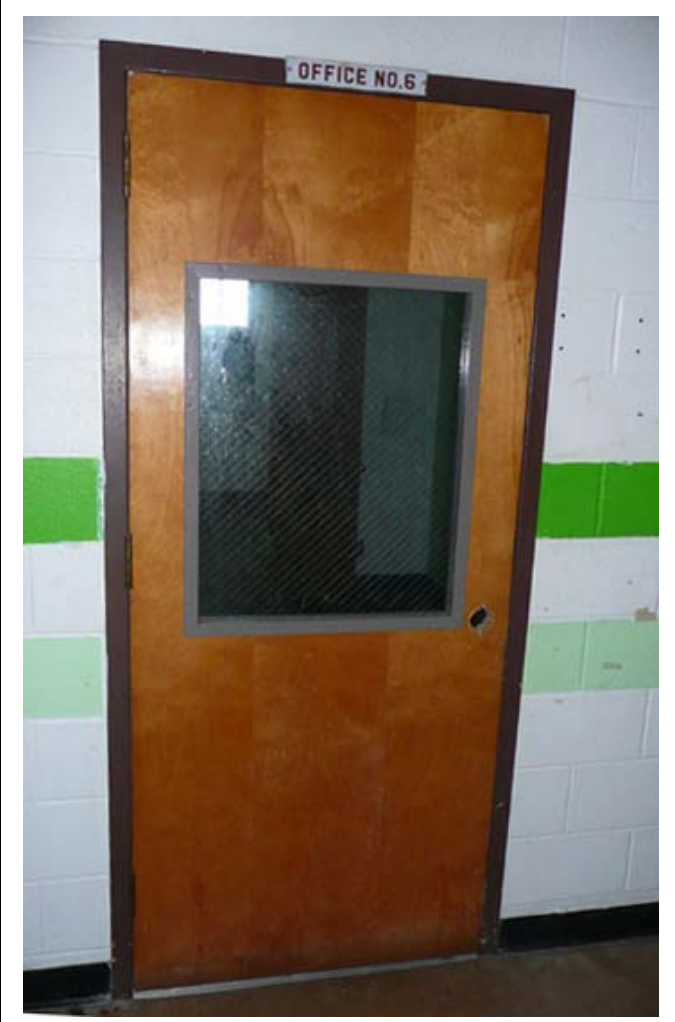

Photo 60. 0 ffice No. 6 replacement door. 


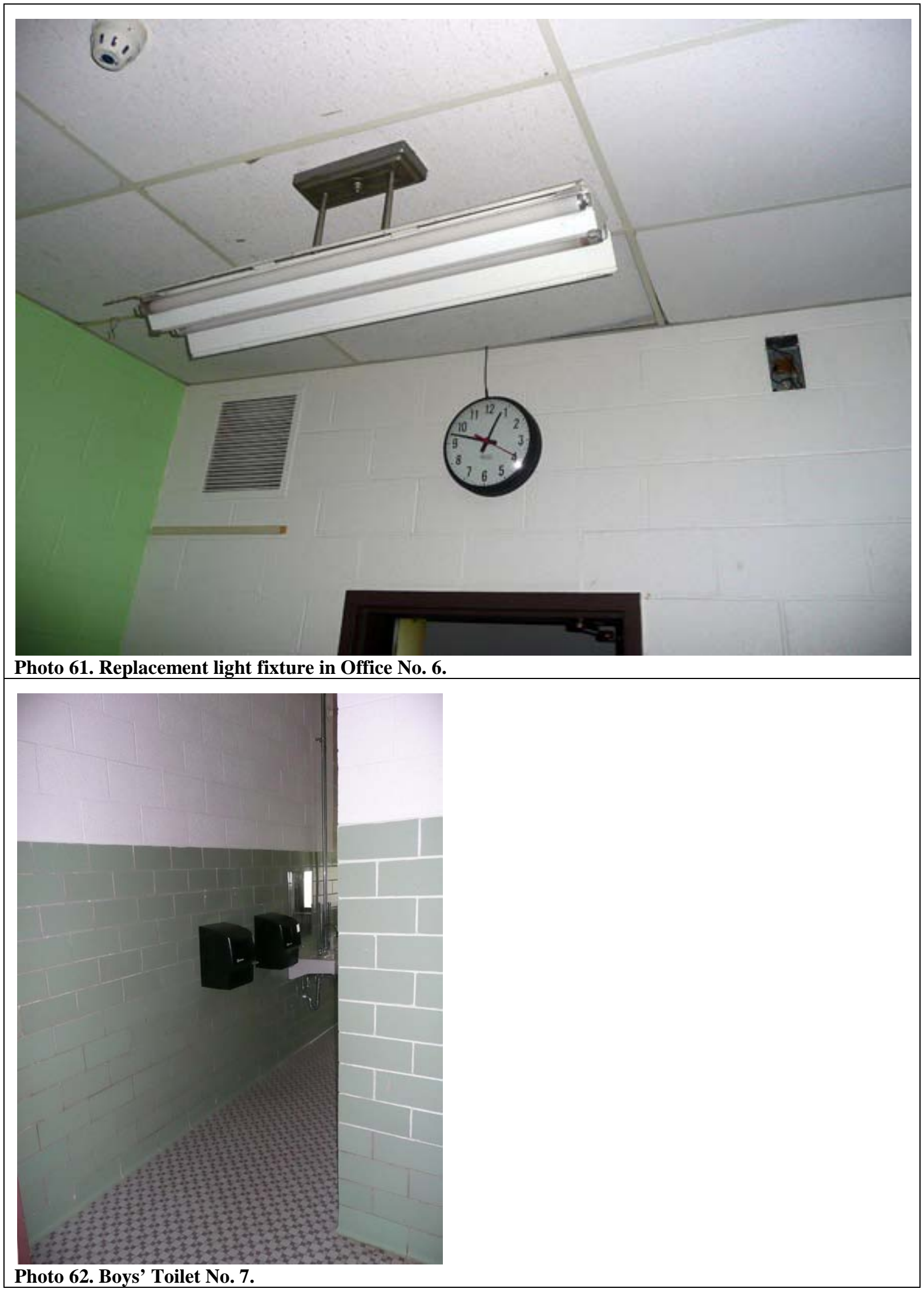




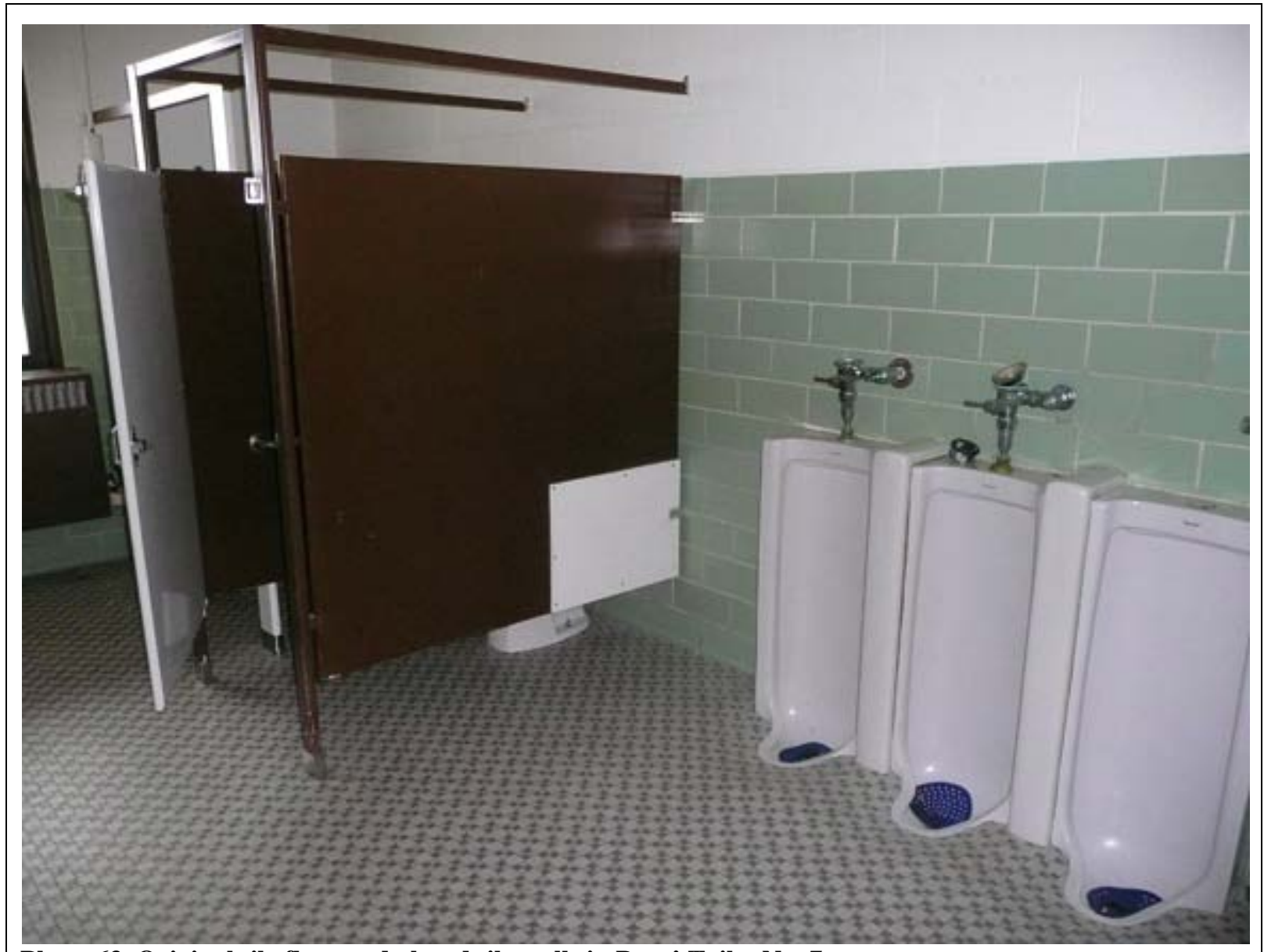

Photo 63. Original tile floor and glazed tile walls in Boys' Toilet No. 7. 


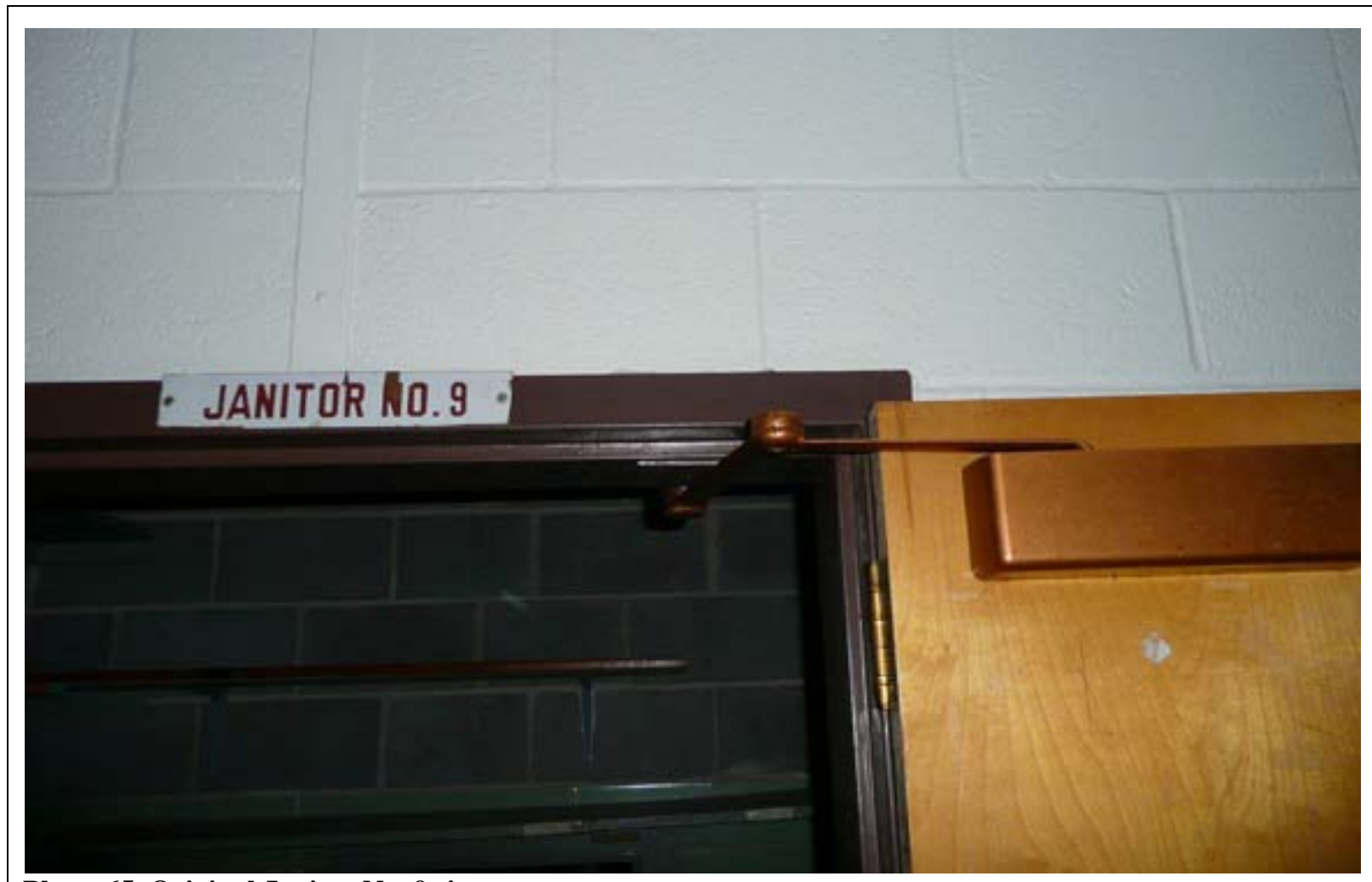

Photo 65. Original J anitor No. 9 sign.

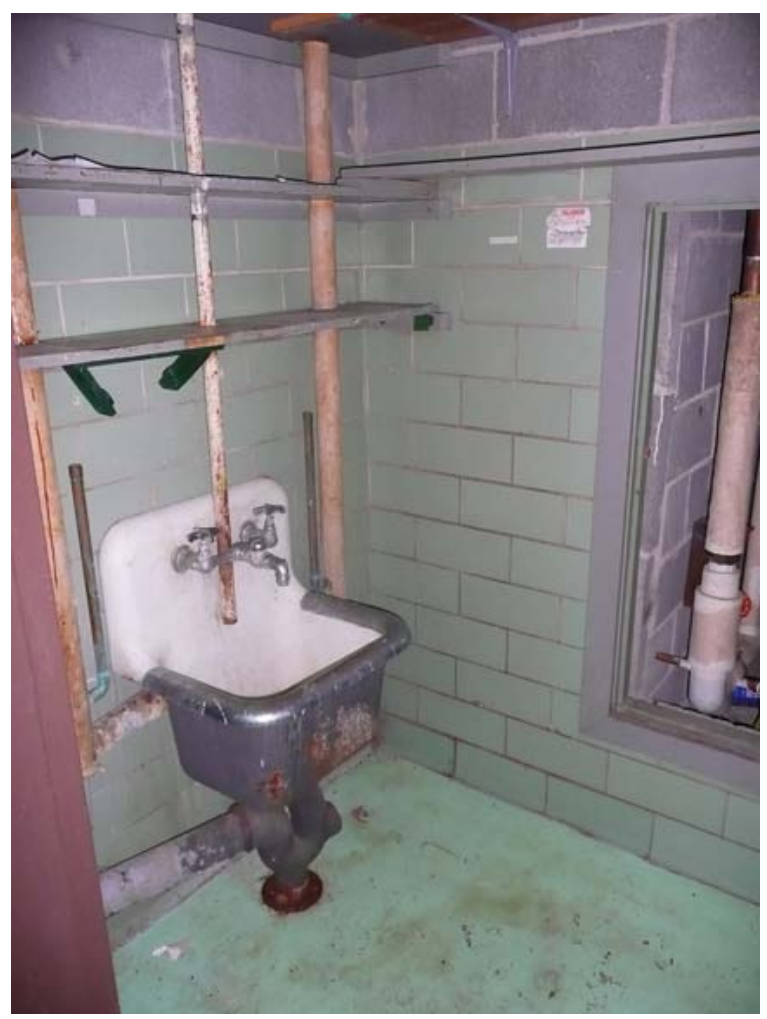

Photo 66. Original glazed tile walls and mop sink in J anitor No. 9. 


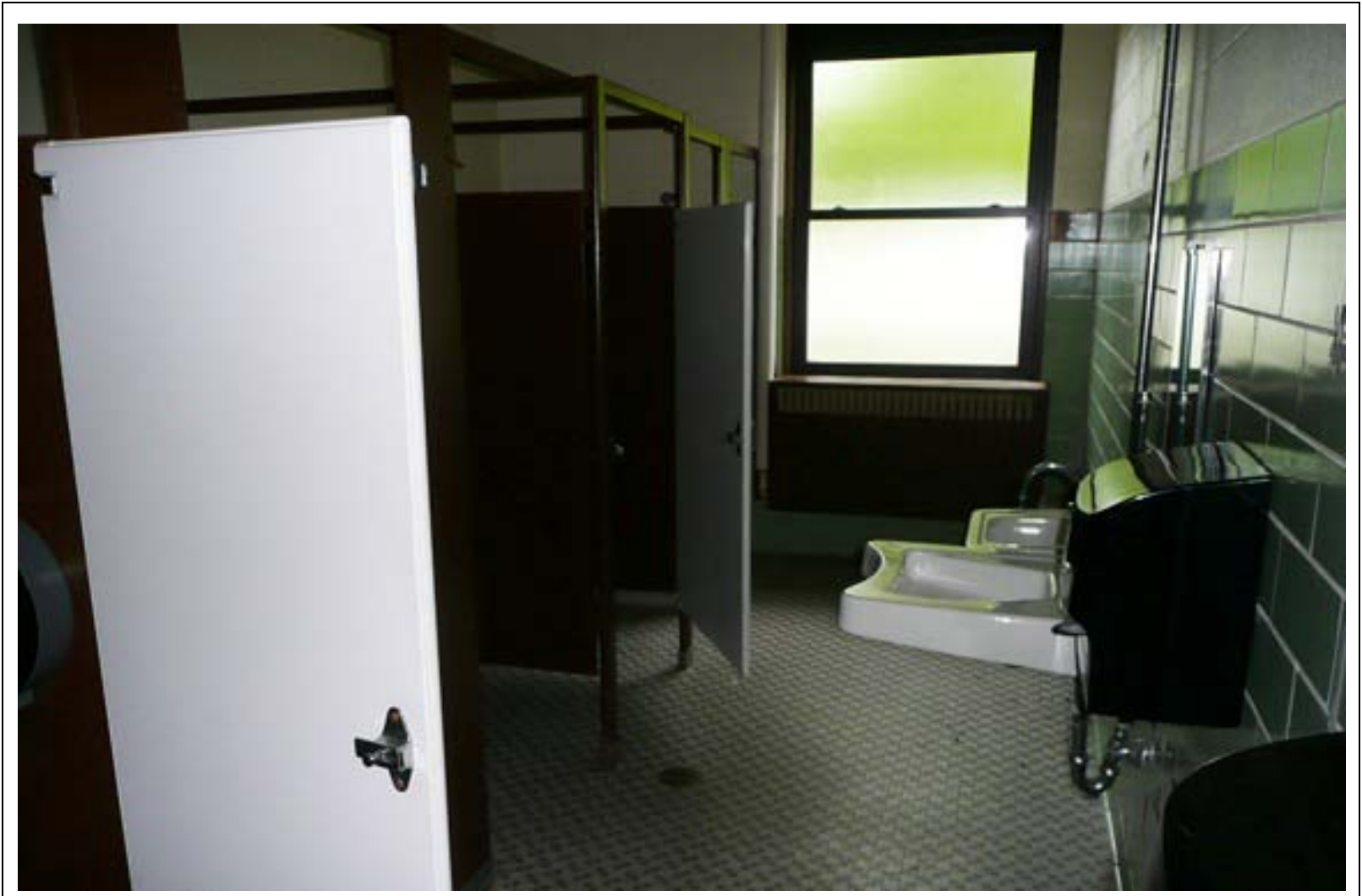

Photo 67. Girls' Toilet No. 8.

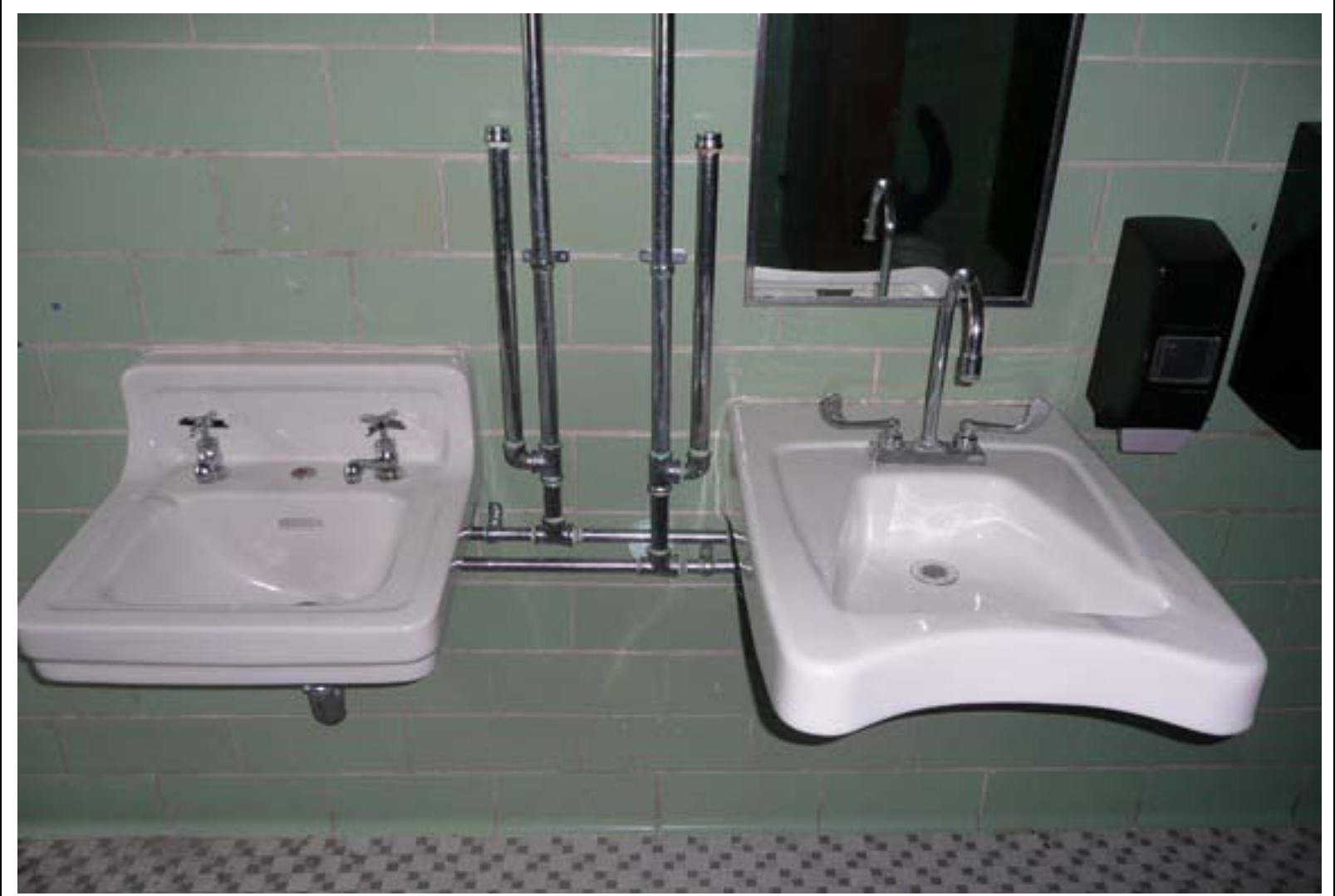

Photo 68. O riginal sink (left) replacement sink (right), original glazed tile wall, and original tile floor in Girls' T oilet No. 8. 


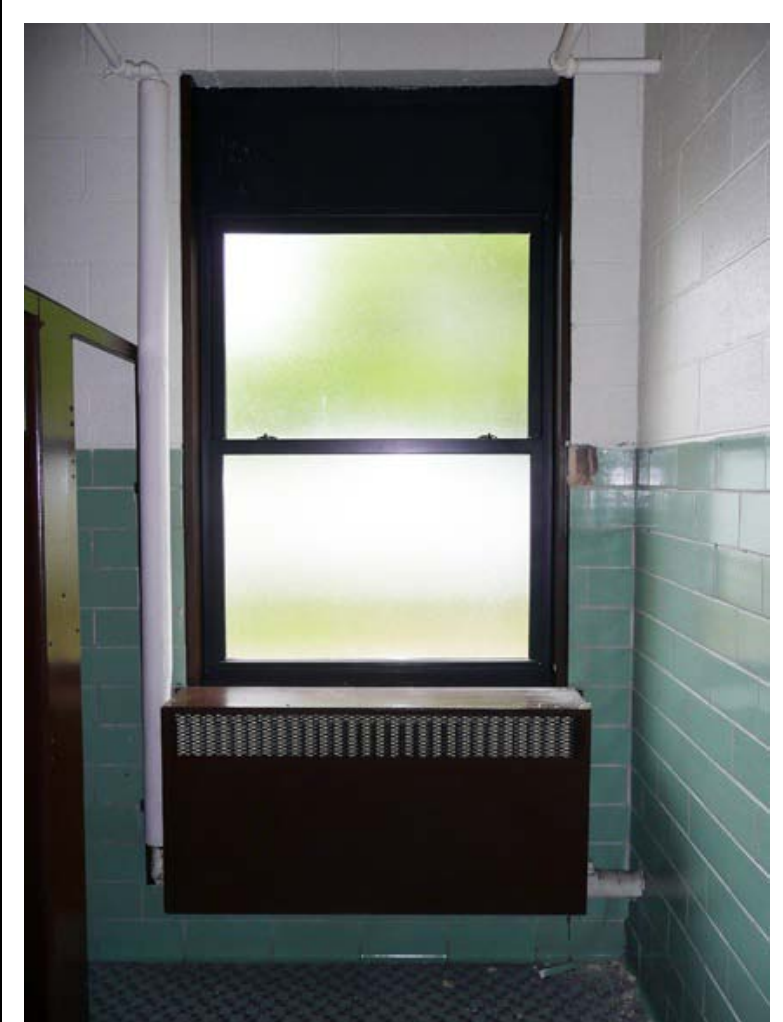

Photo 69. Replacement window in Girls' Toilet No. 8.

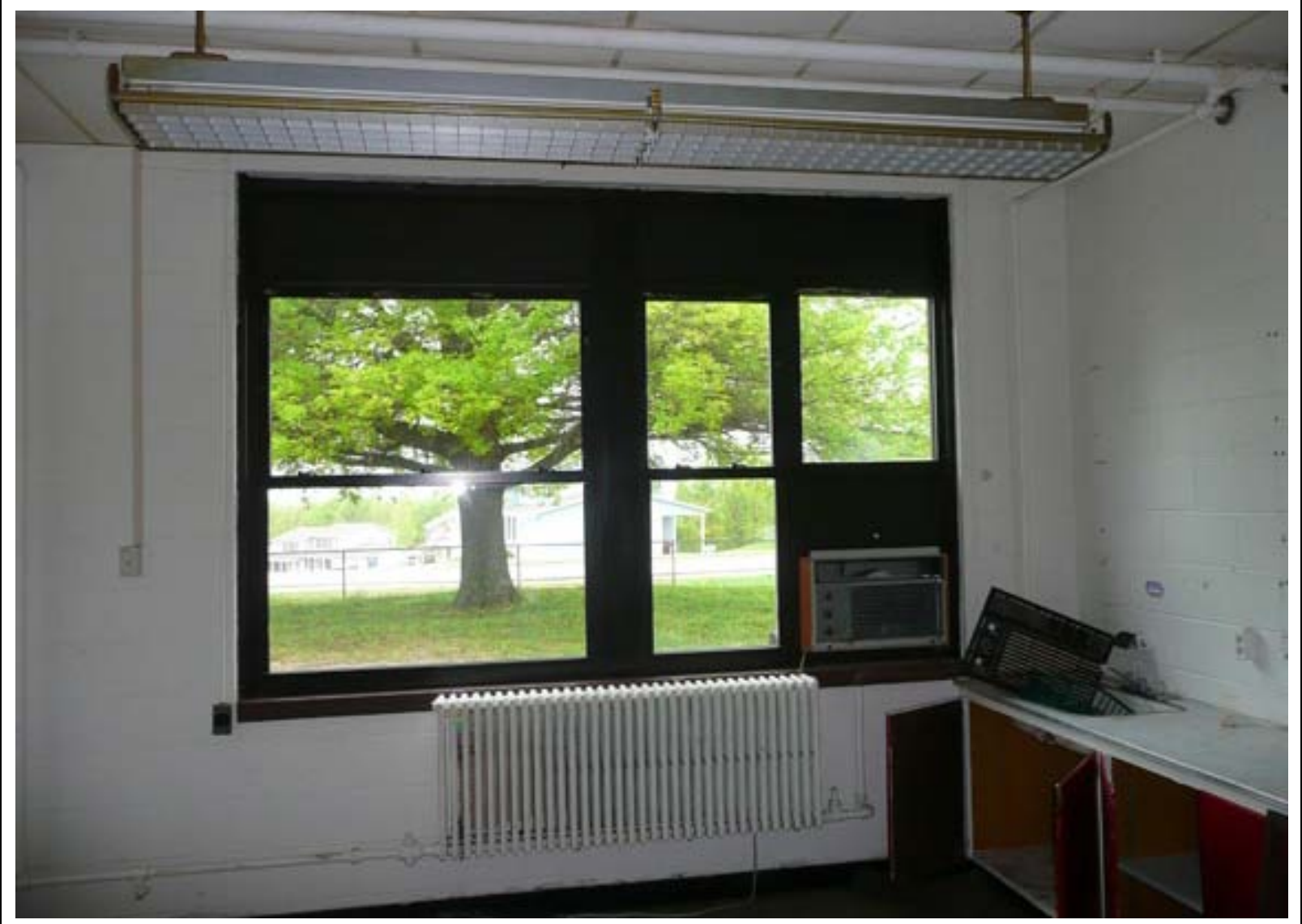

Photo 70. Teachers' W ork R oom No. 10. 


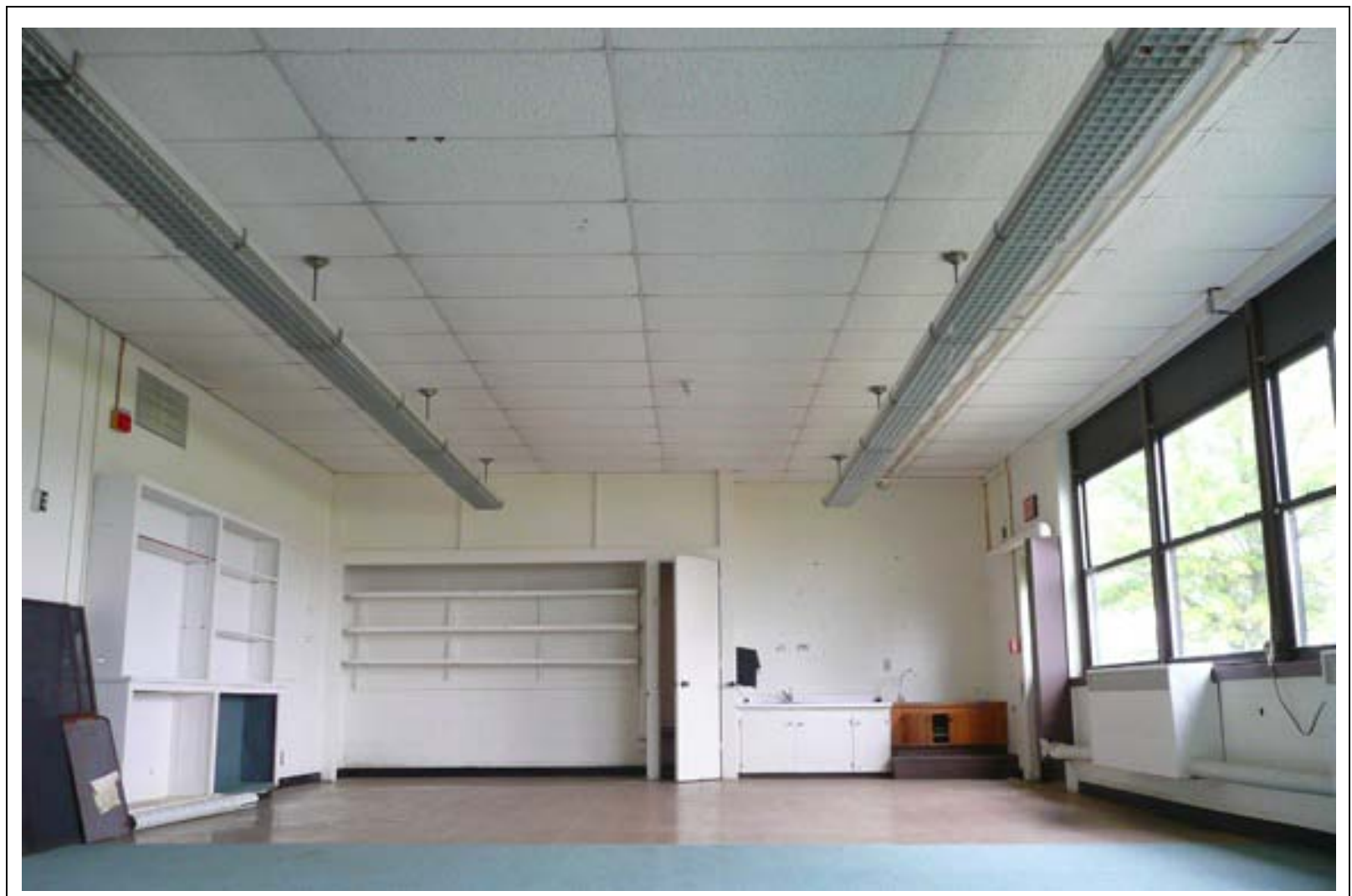

Photo 71. Interior of Classroom No. 11.

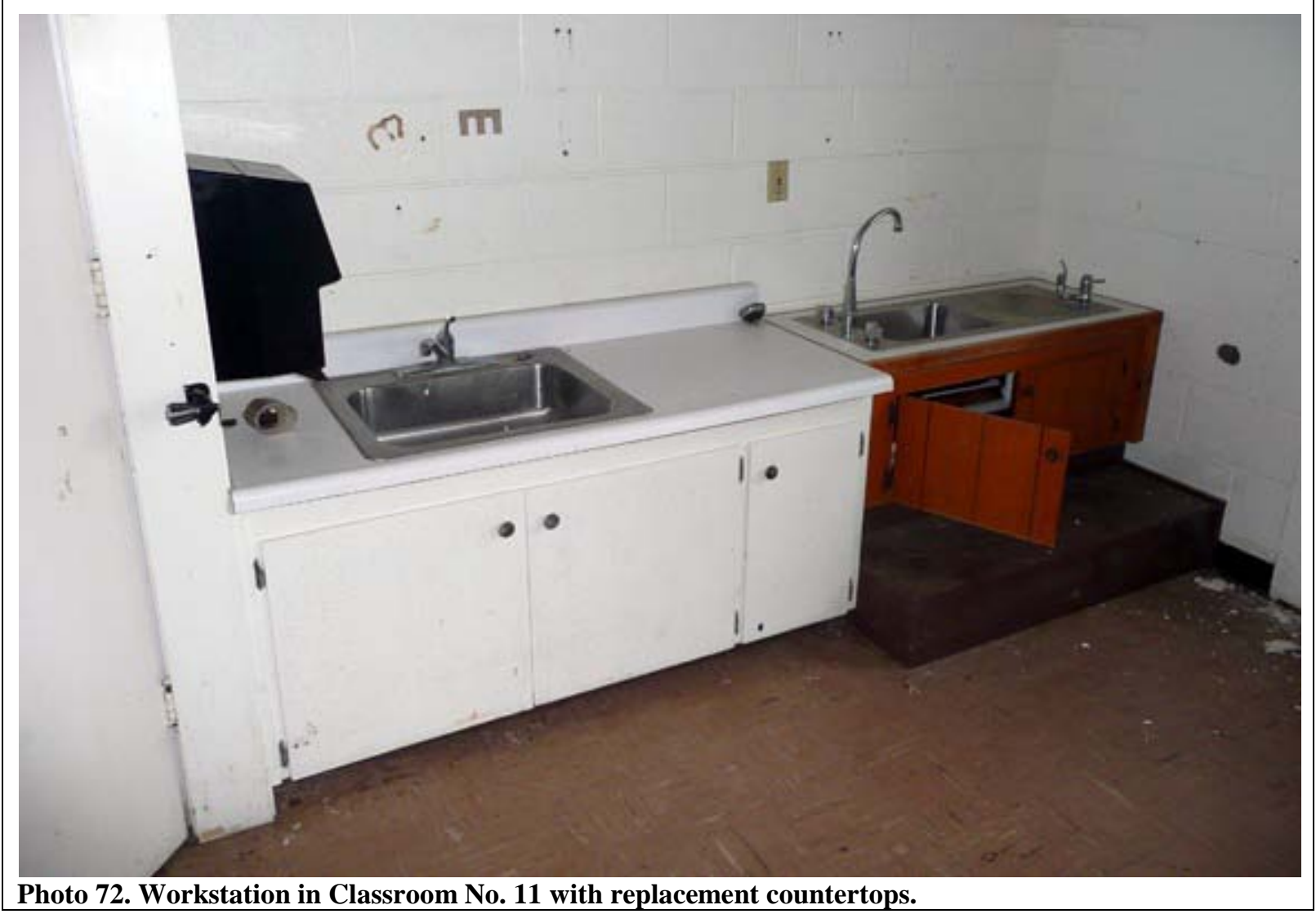




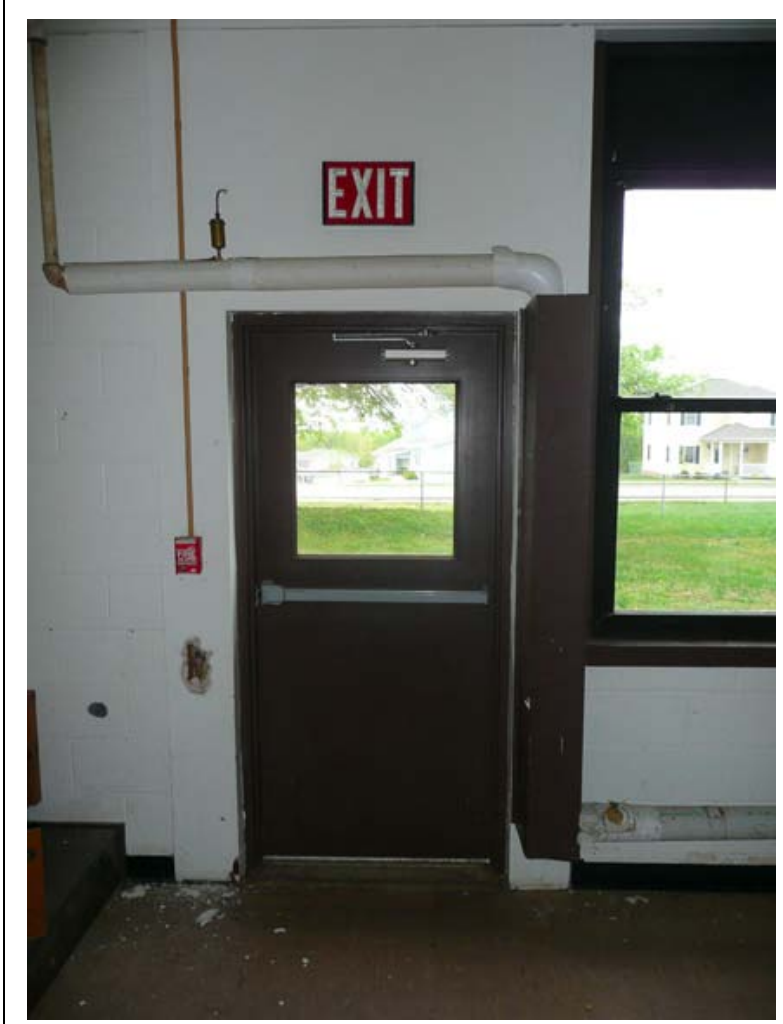

Photo 73. New door leading to the outside from Classroom No. 11.

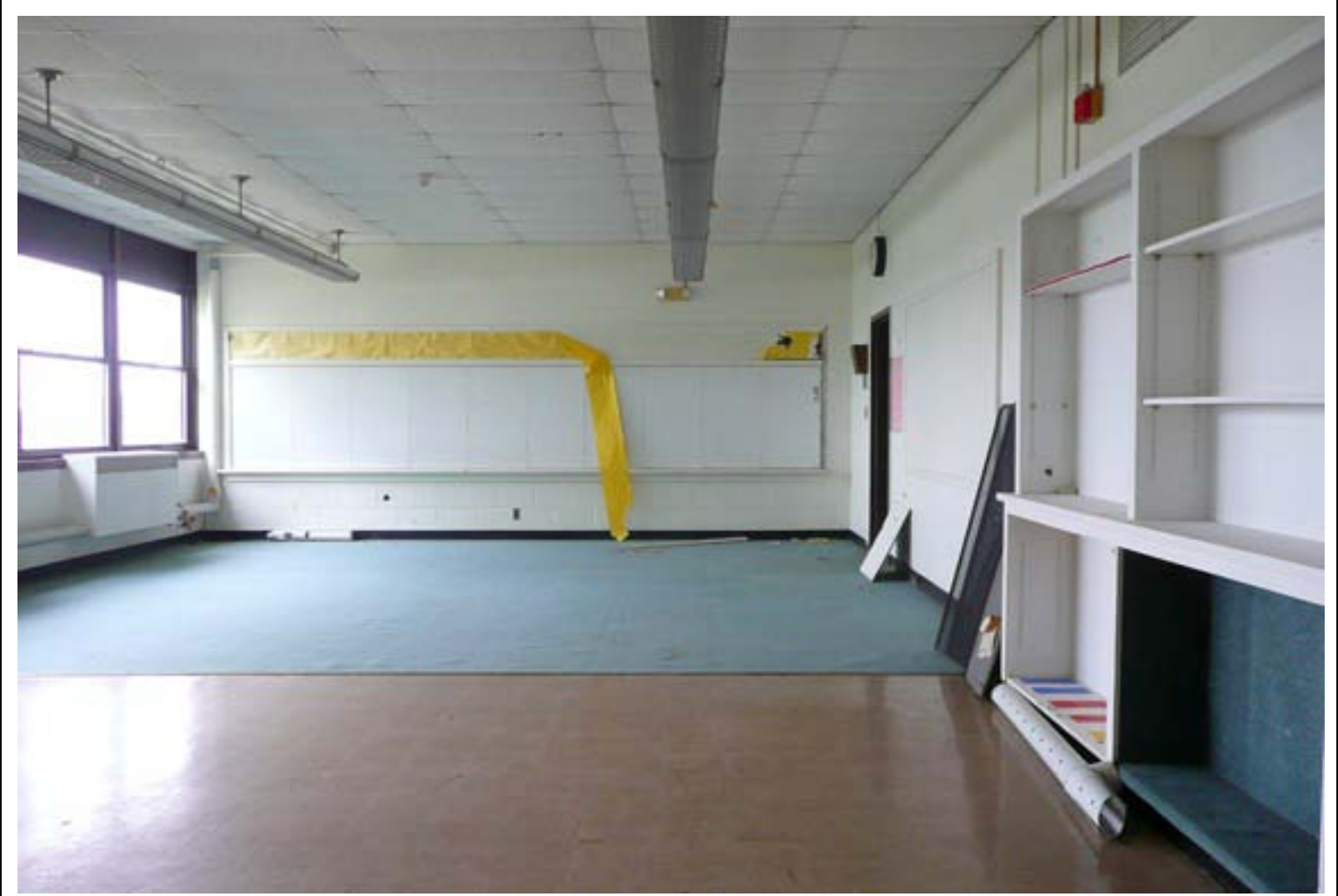

Photo 74. Interior of Classroom No. 11. 


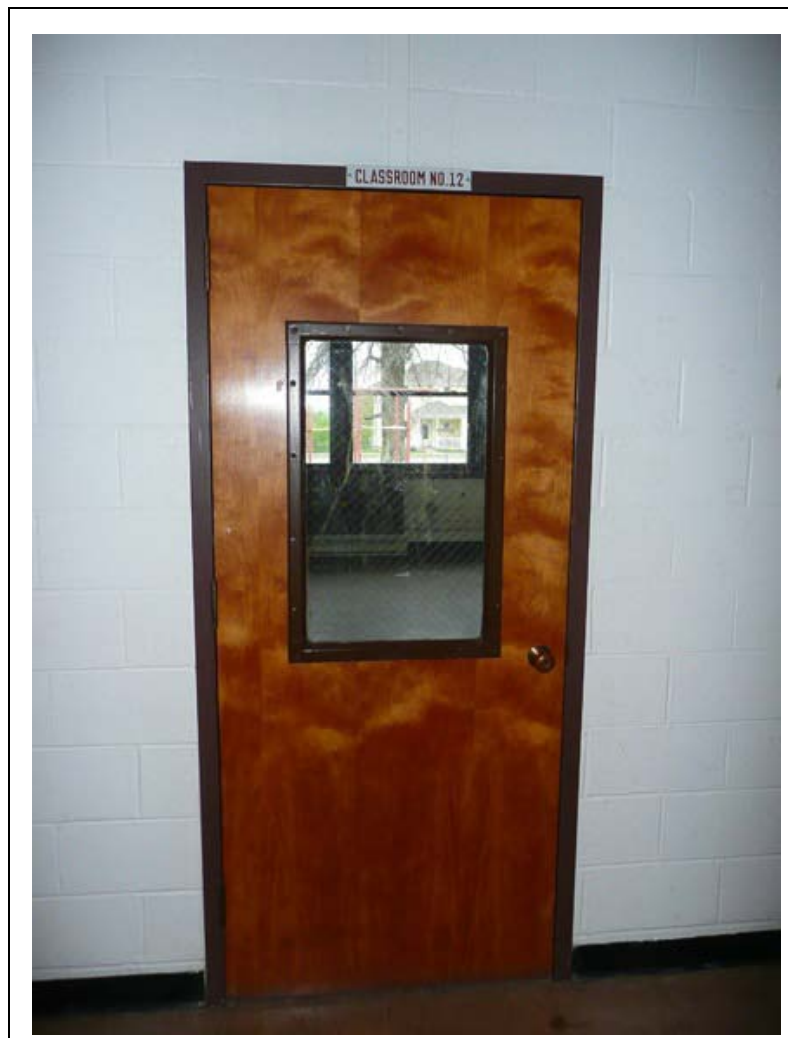

Photo 75. Classroom No. 12 replacement door.

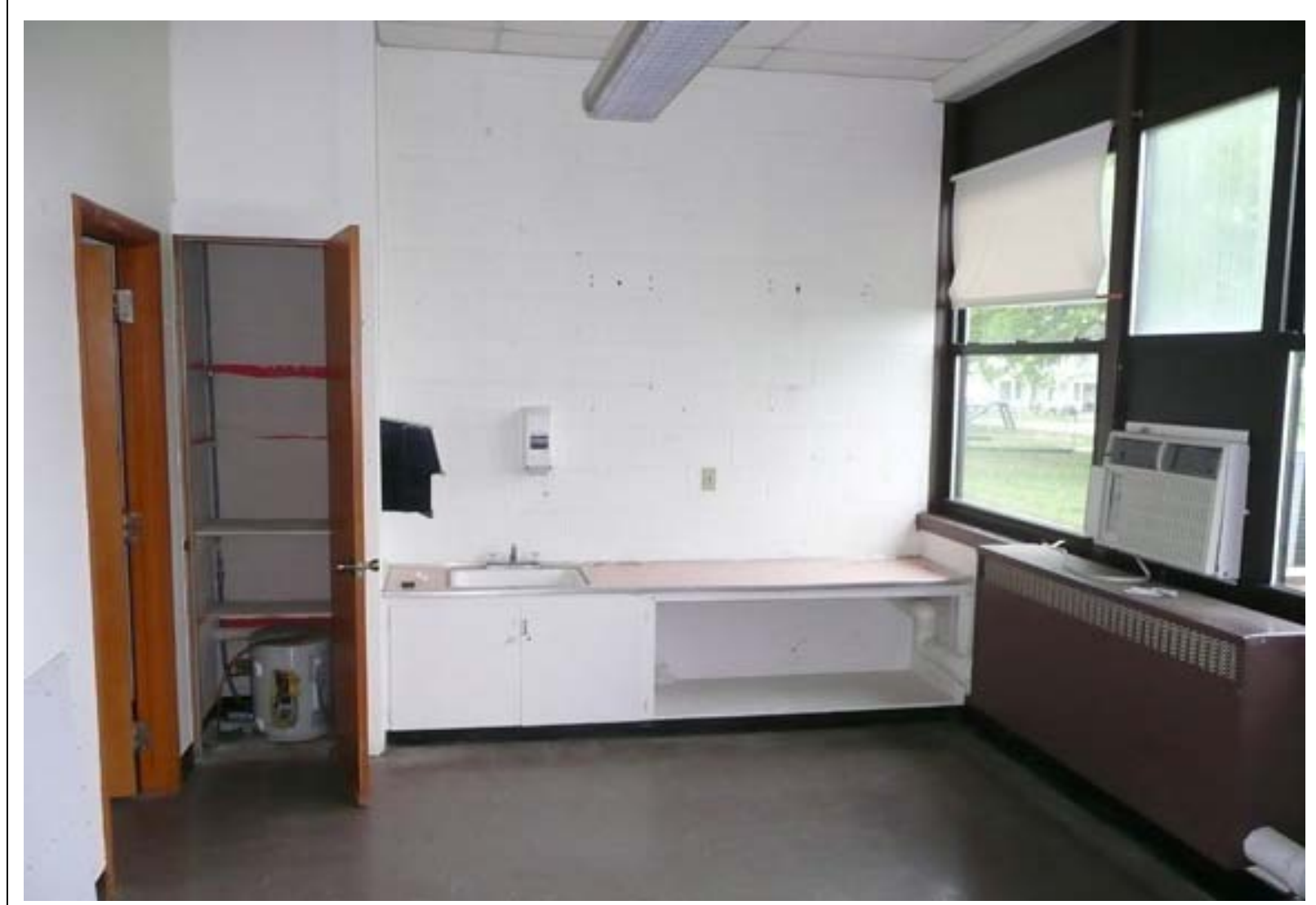

Photo 76. W orkstation and storage closet in Classroom No. 12 and a newer enclosed addition on the left side of the image. 


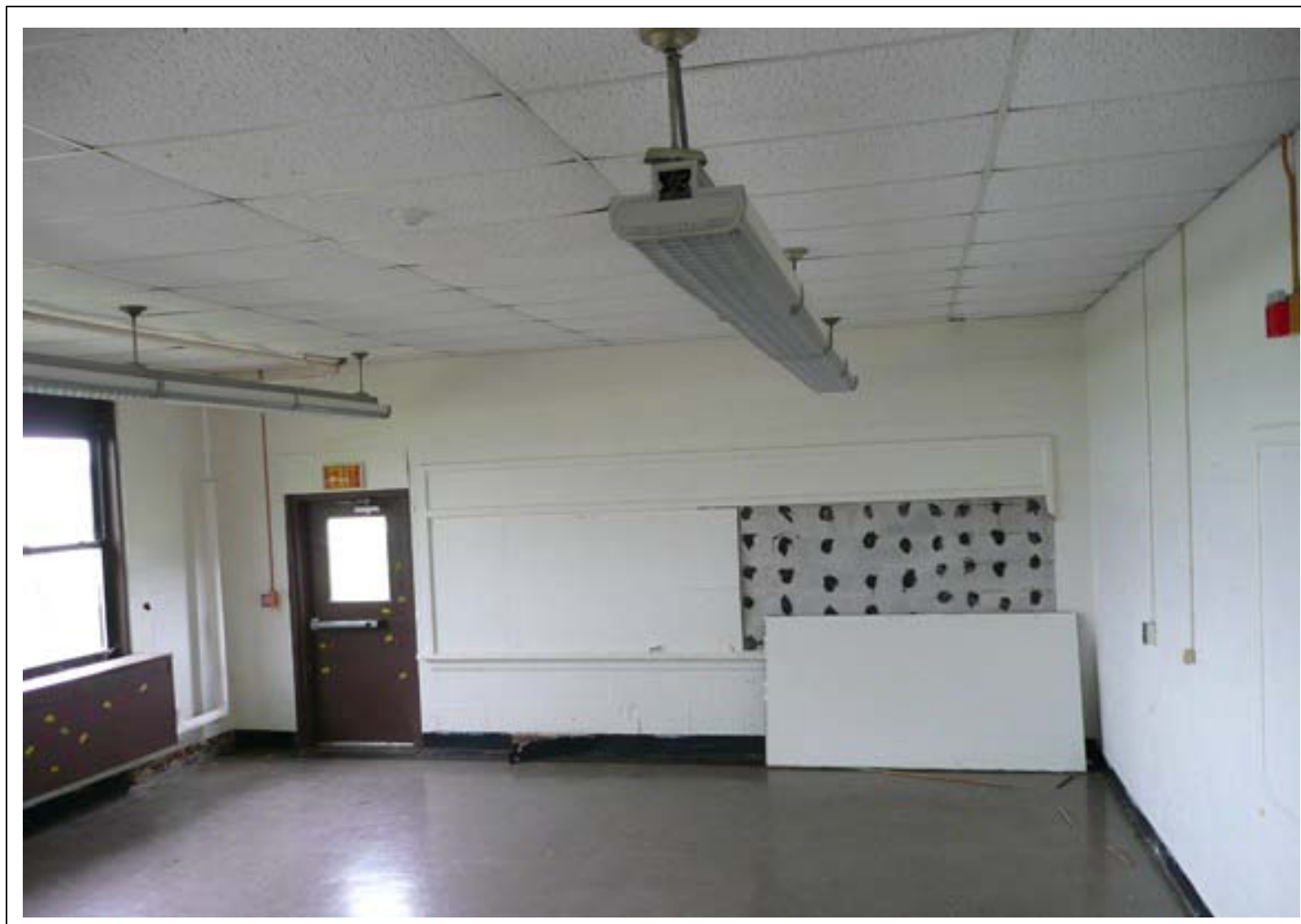

Photo 77. Interior Classroom No. 12.

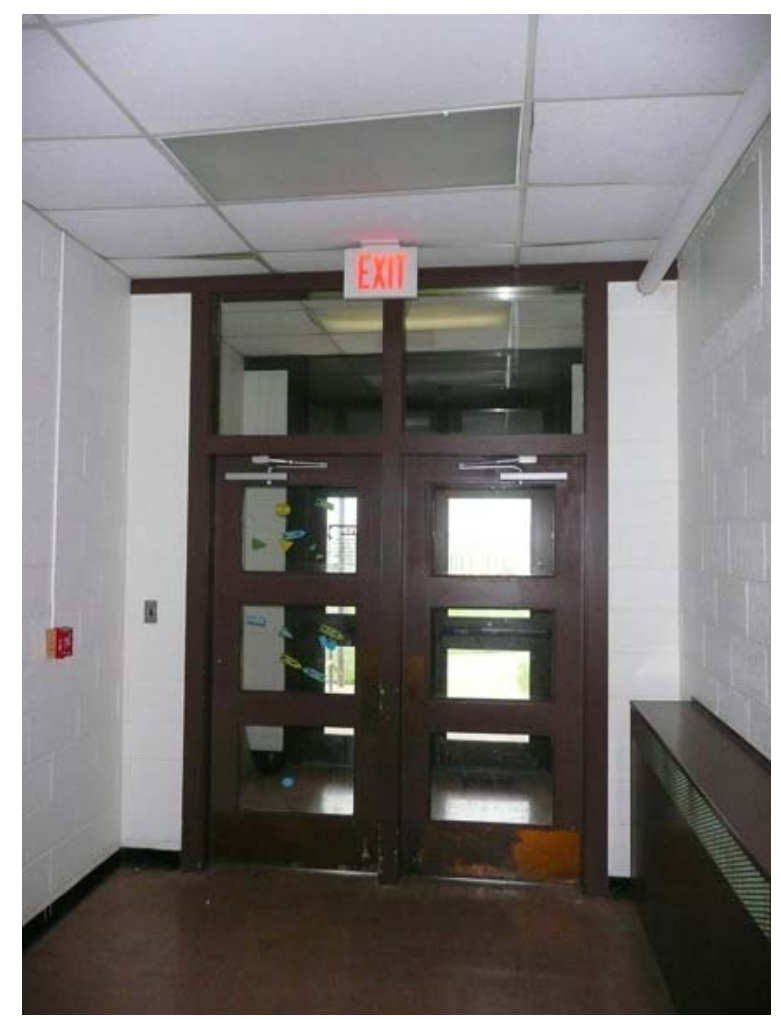

Photo 78. Original metal vestibule doors and transom located at the east end of the corridor. 


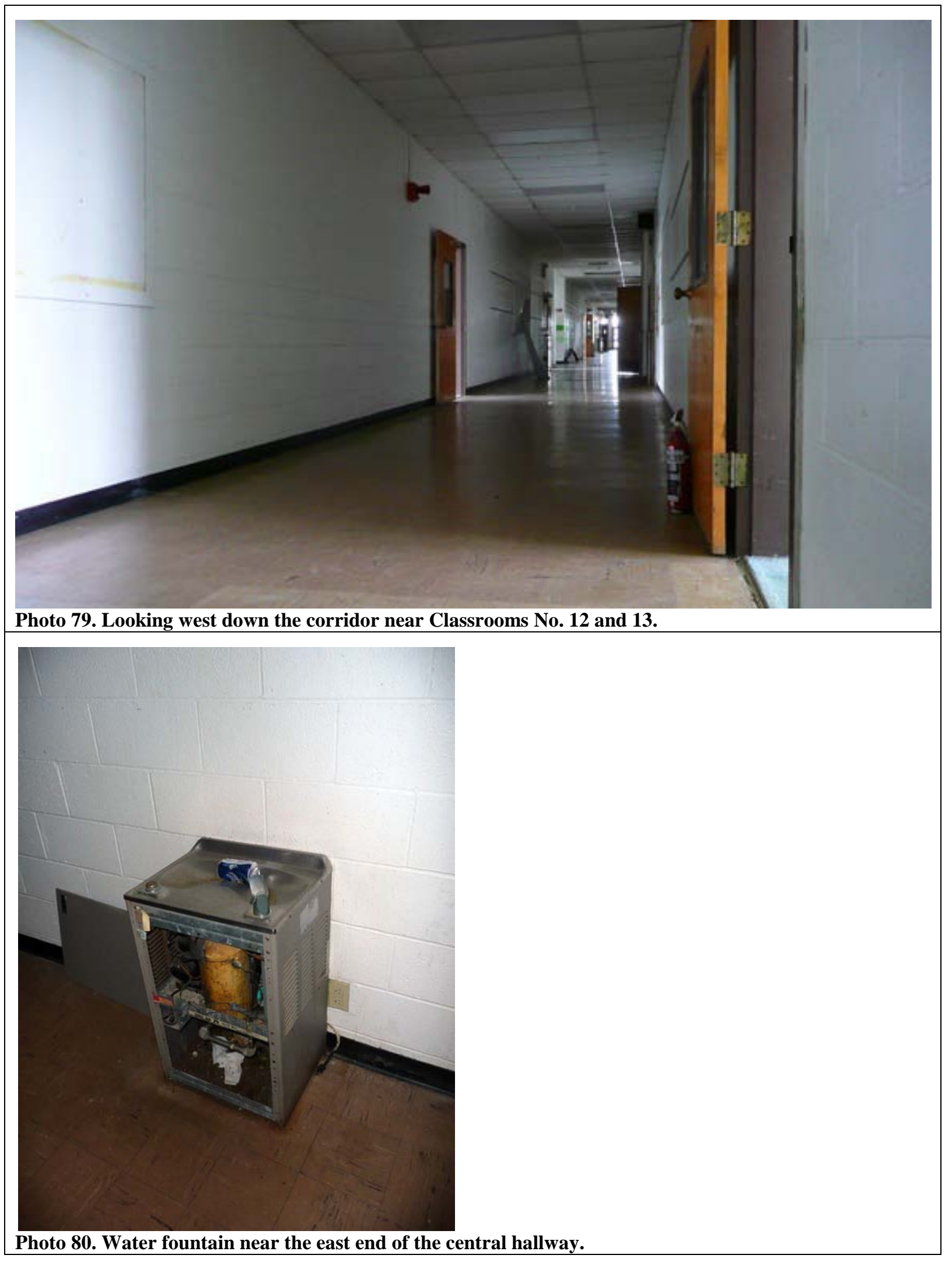




\section{CLASSROOM NO.13}

Photo 81. Original Classroom No. 13 sign.

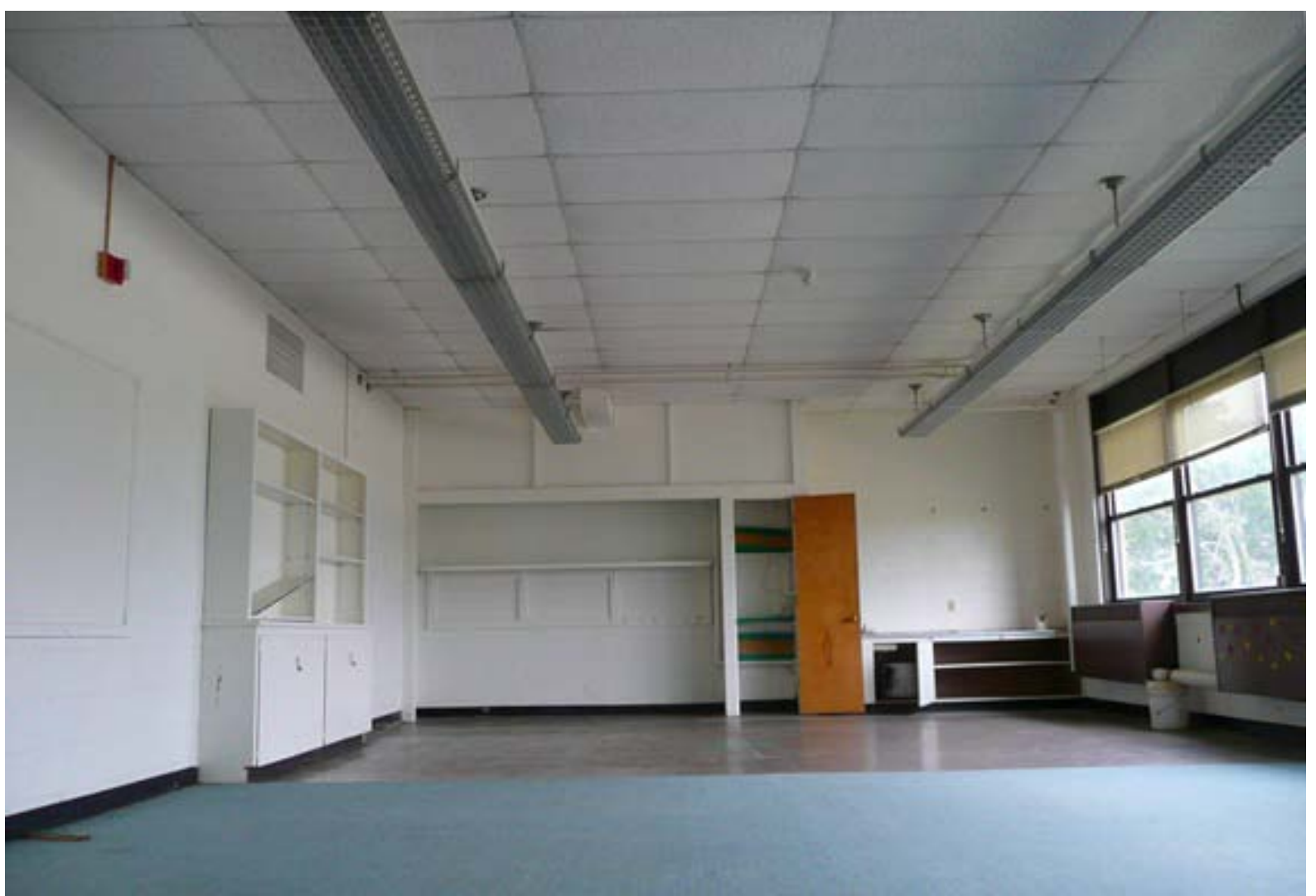

Photo 82. Interior Classroom No. 13. 


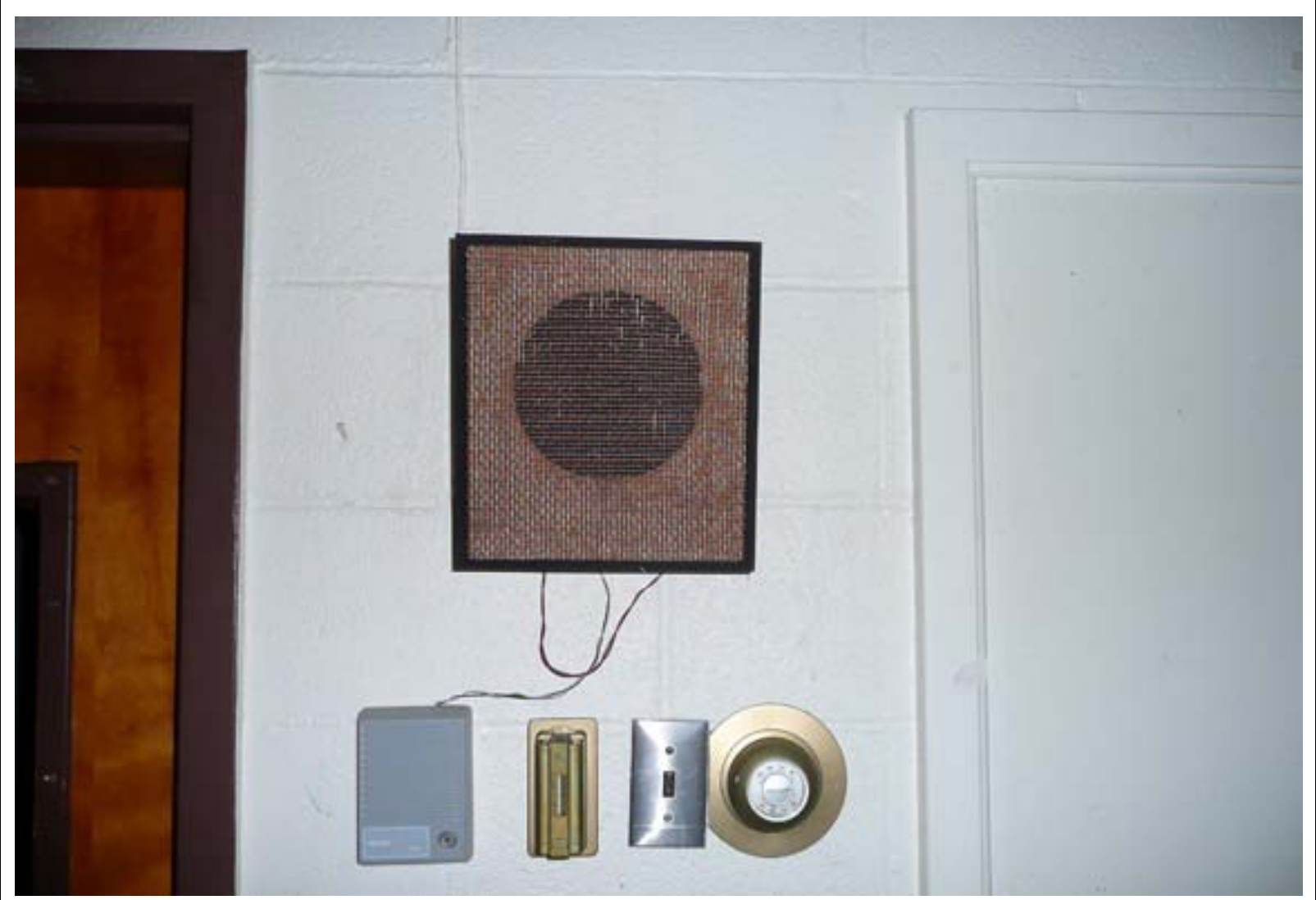

Photo 83. Speaker system located in Classroom No. 13.

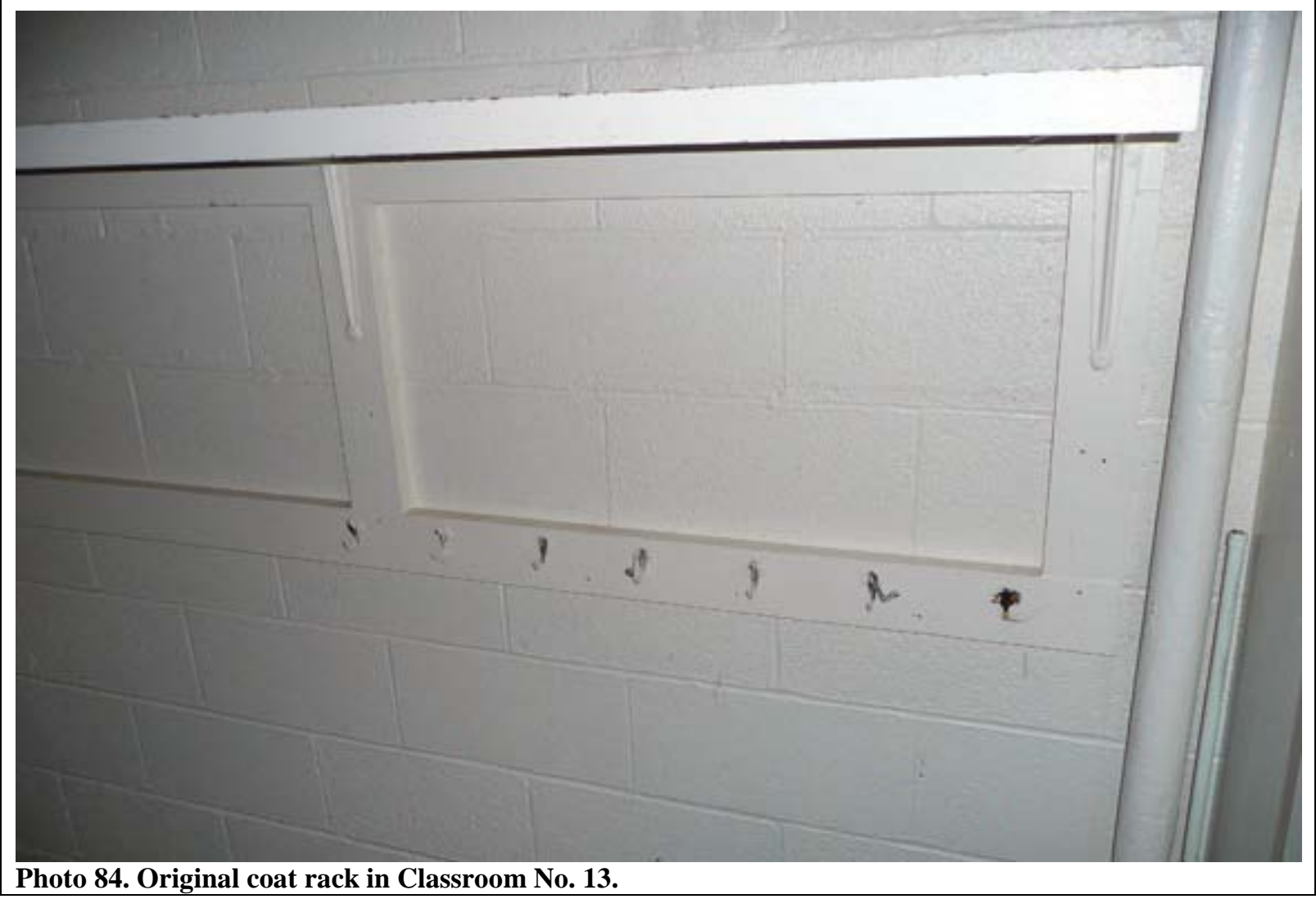




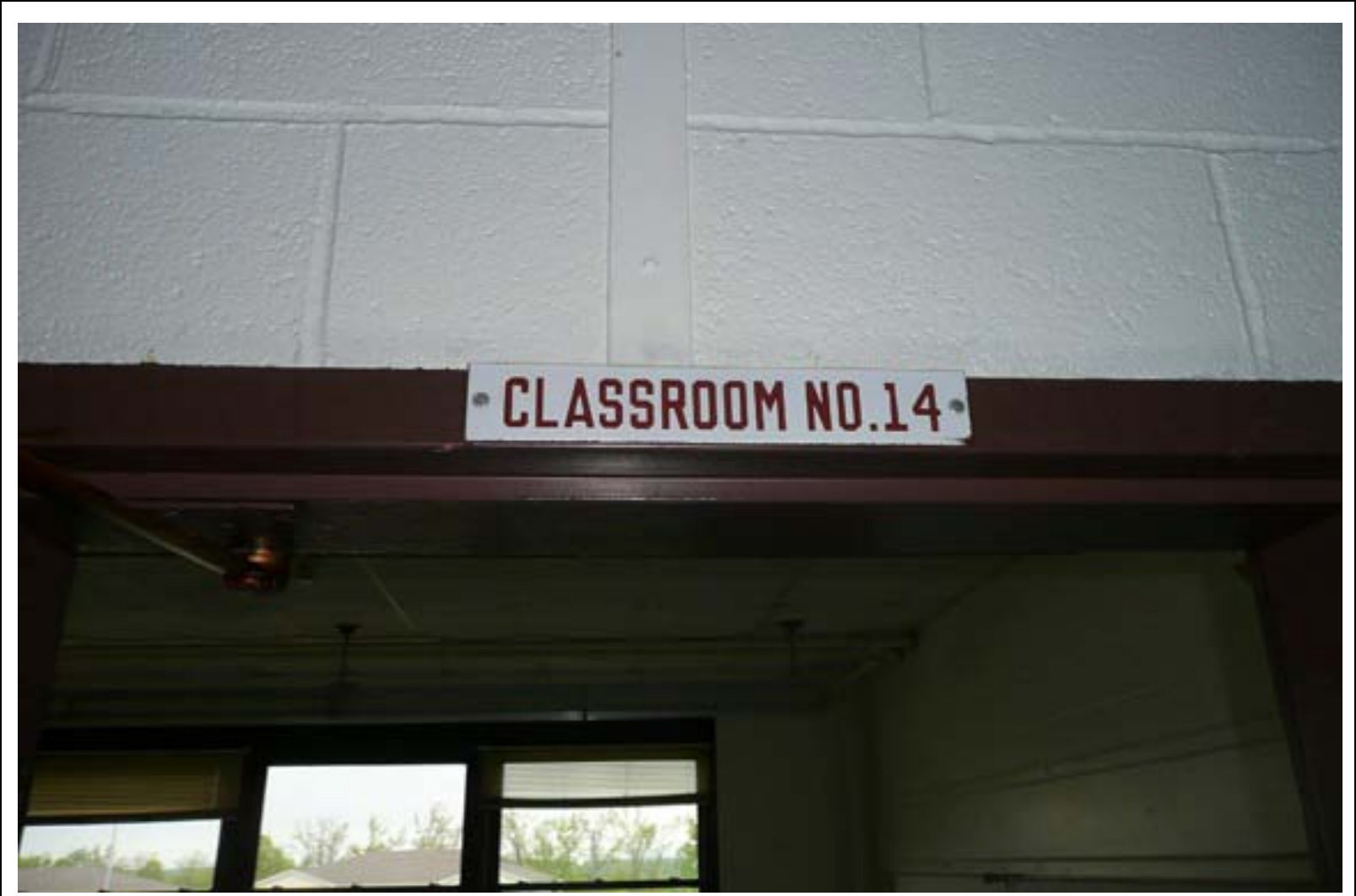

Photo 85. Original Classroom No. 14 sign.

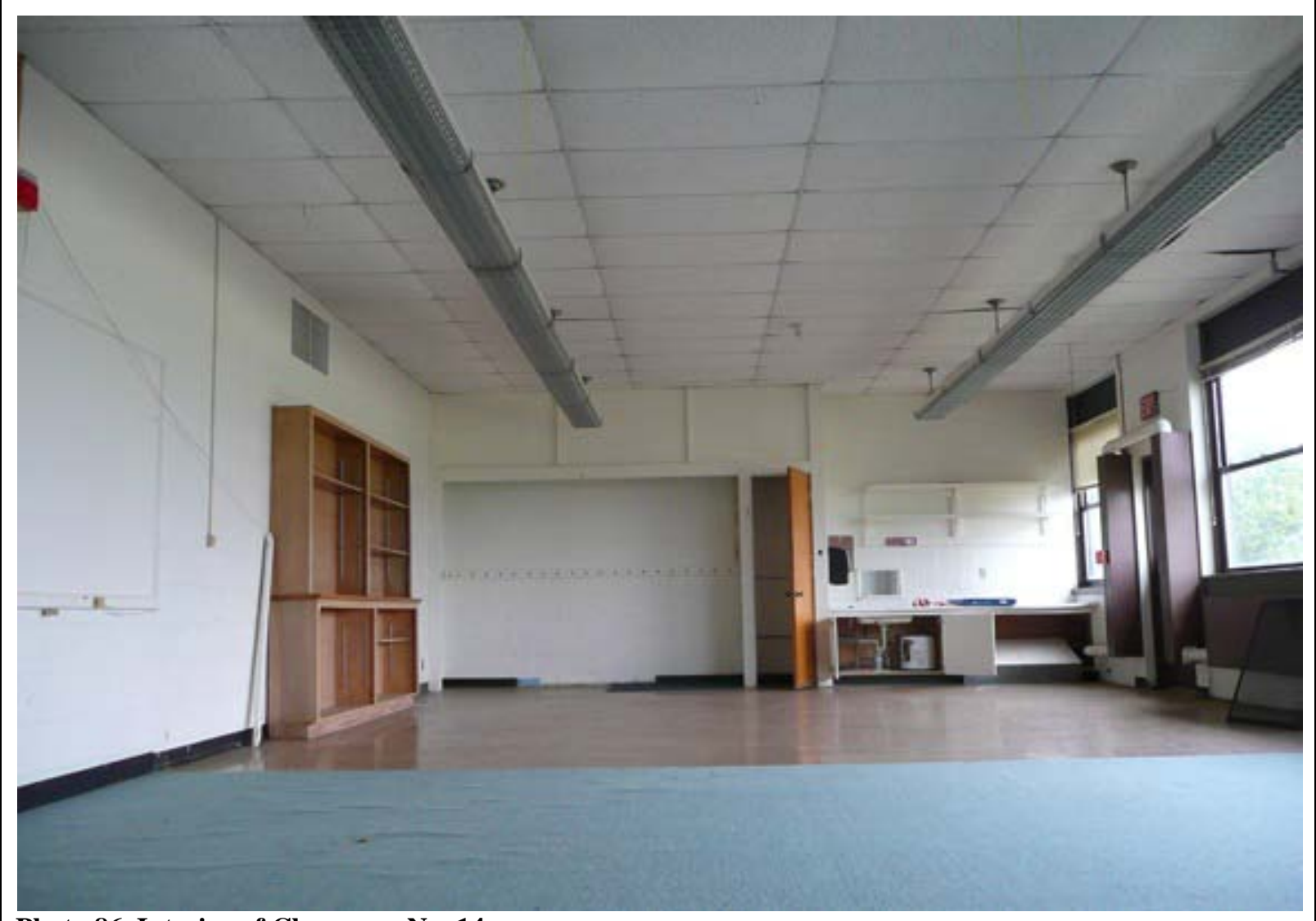




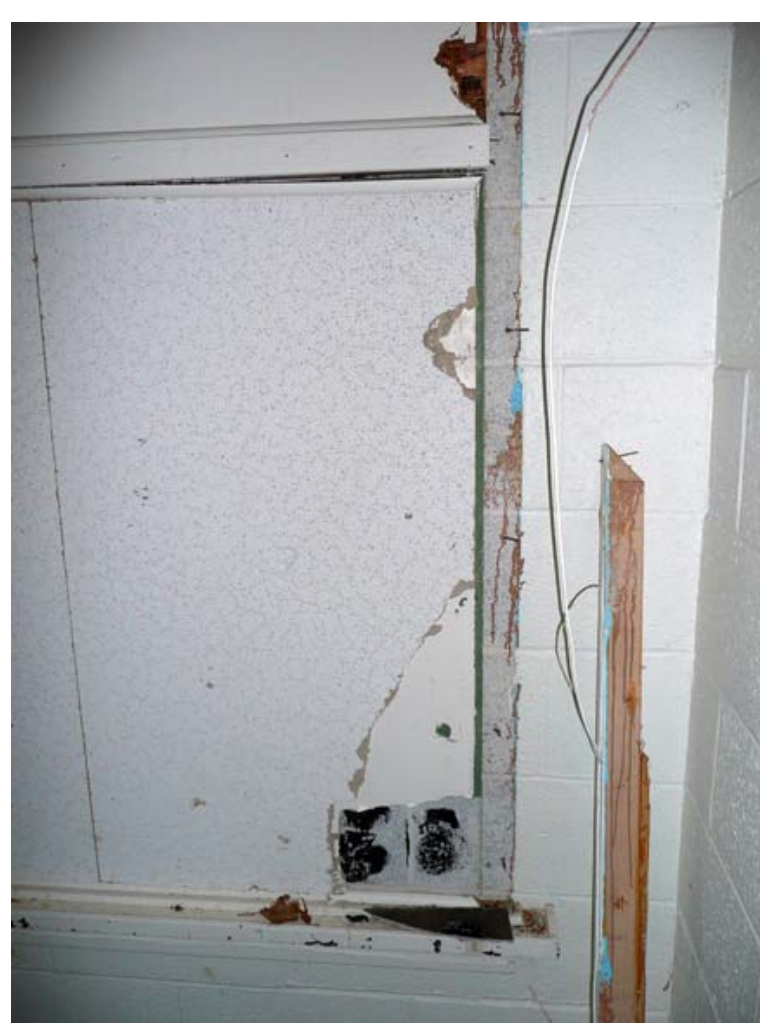

Photo 87. L ooking at the original chalkboard frame in C lassroom No. 14.

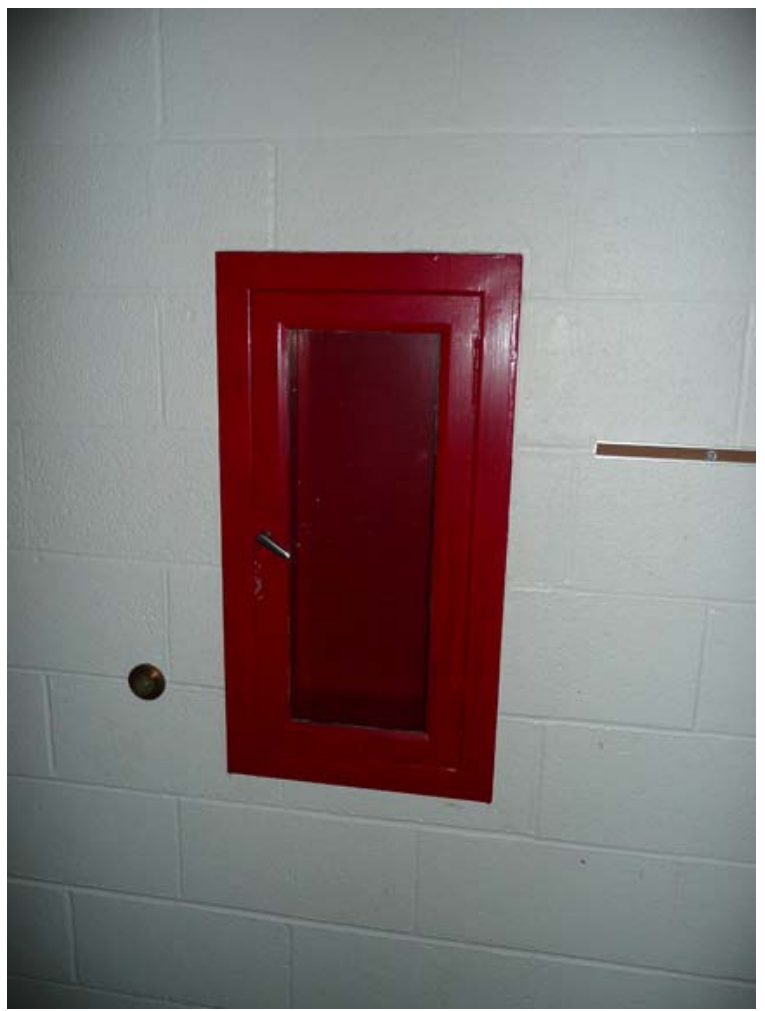

Photo 88. Fire extinguisher enclosure. 


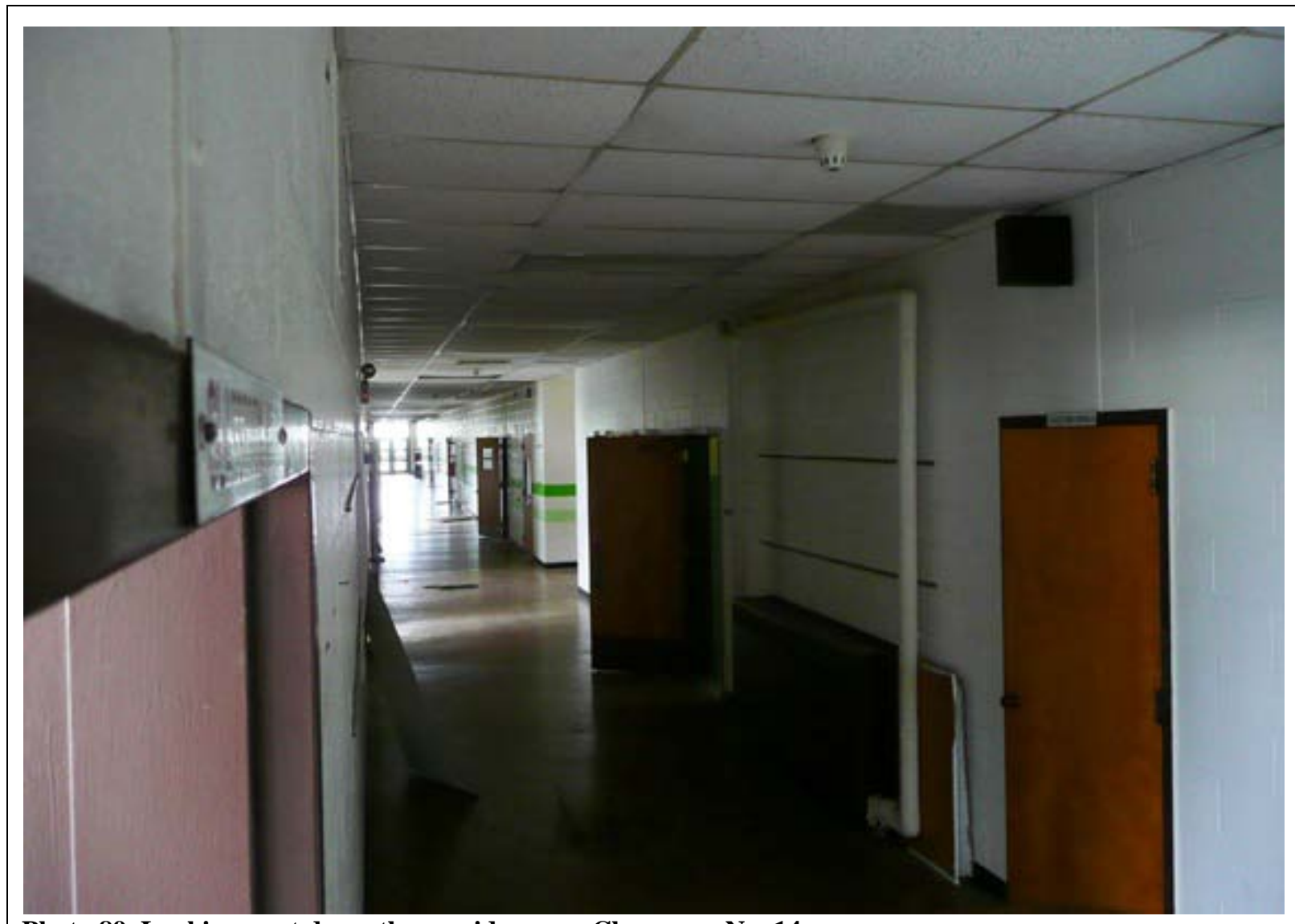

Photo 89. L ooking west down the corridor near Classroom No. 14.

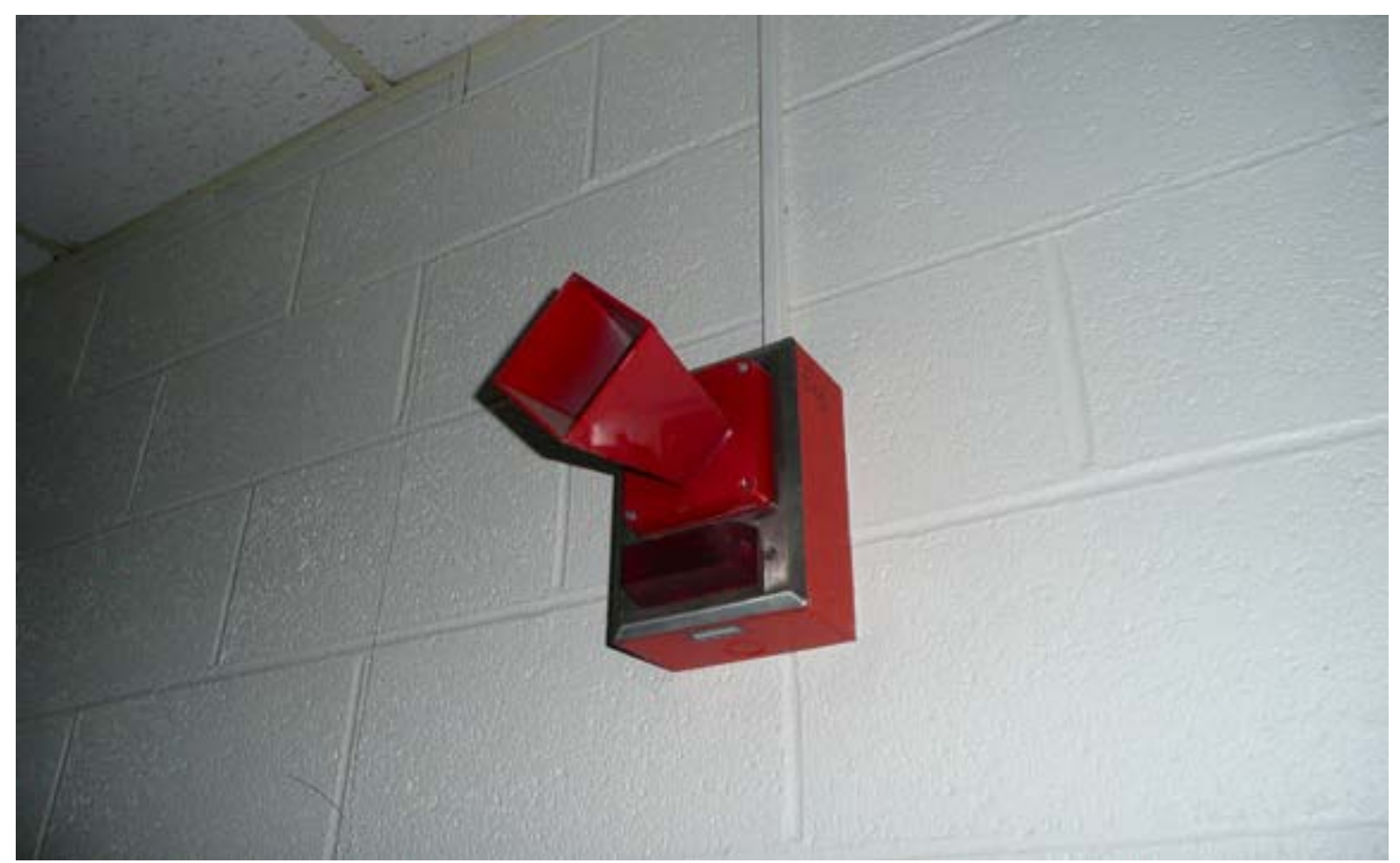

Photo 90. Original alarm system. 


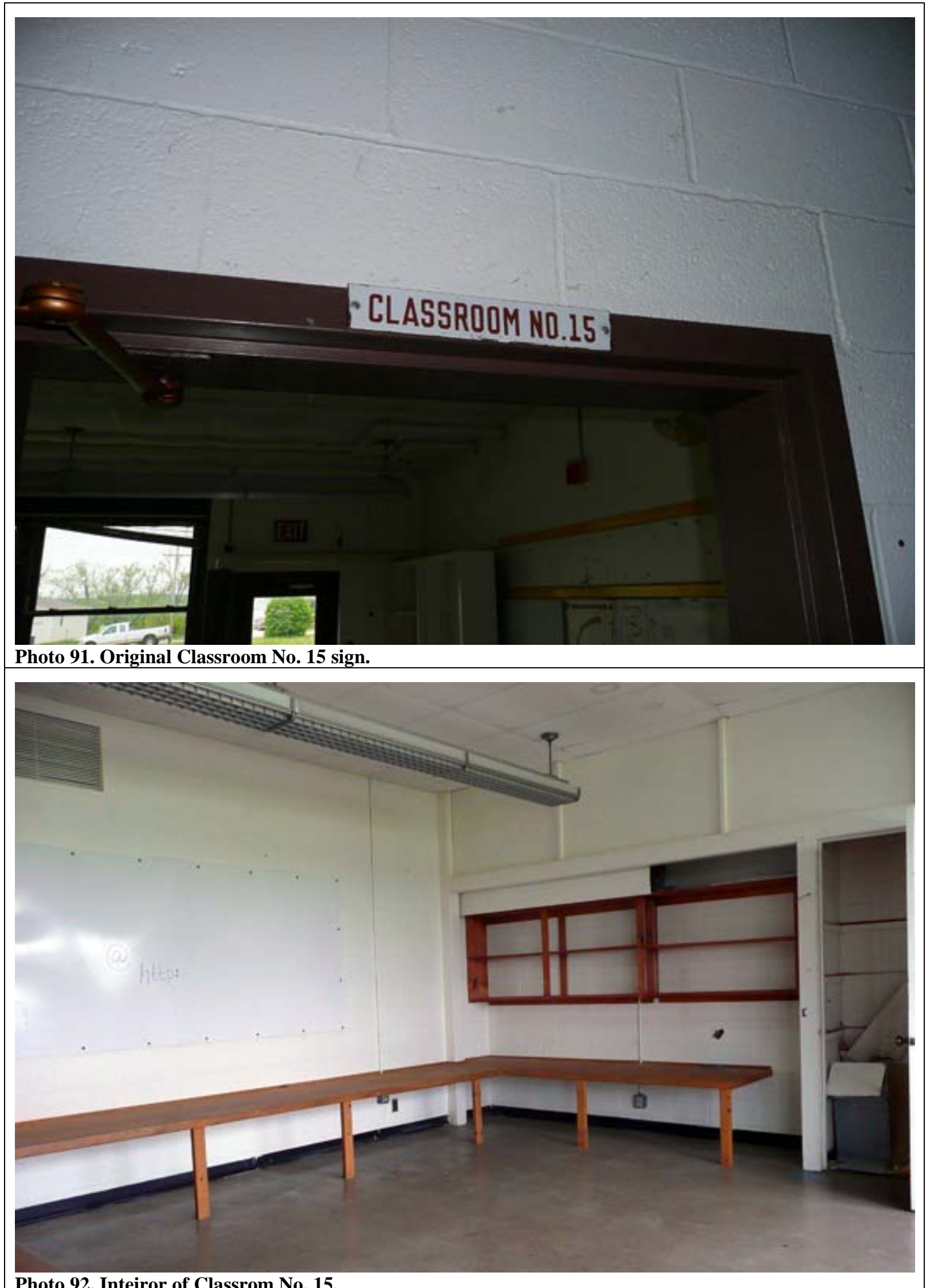

Photo 92. Inteiror of C lassrom No. 15. 


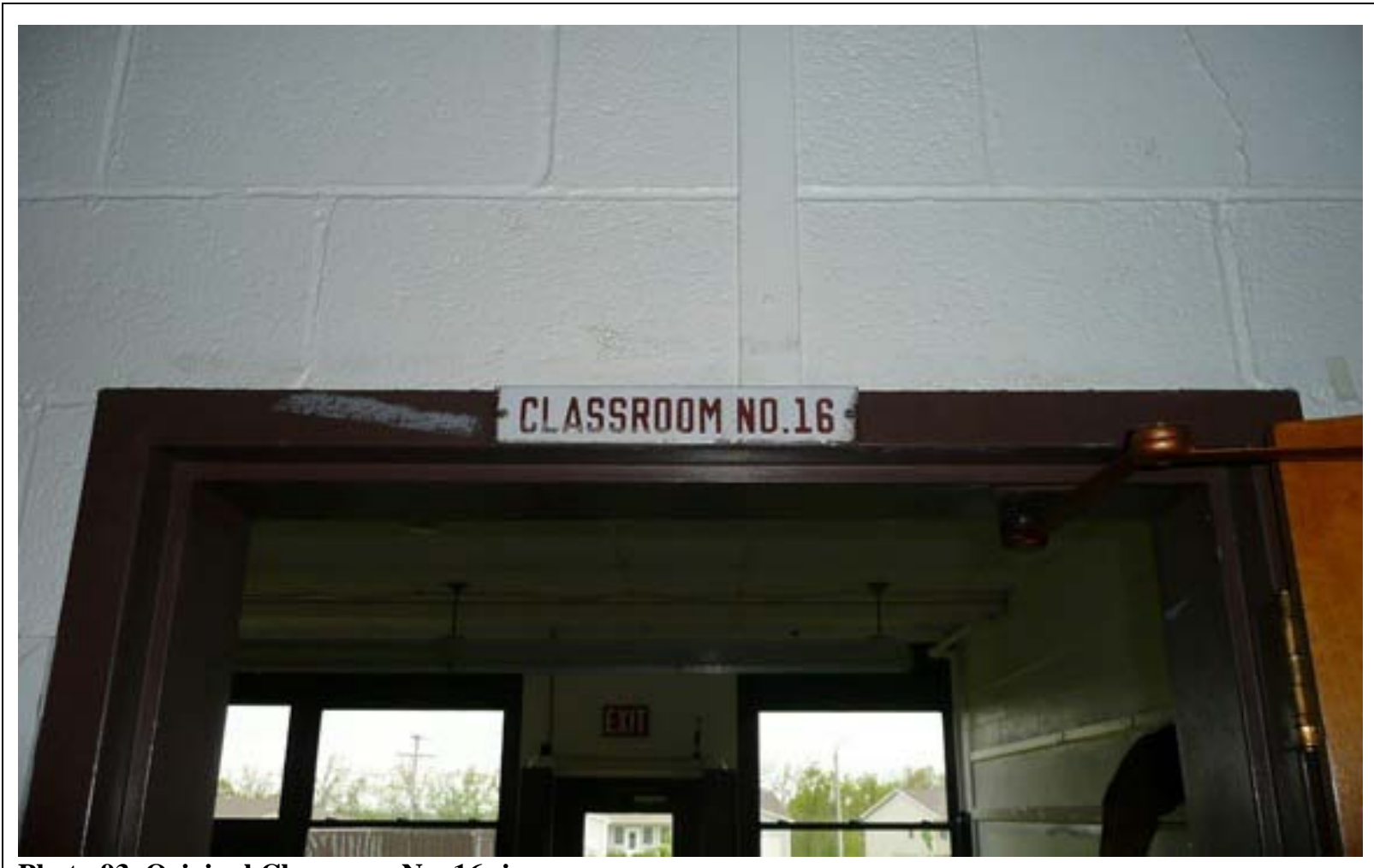

Photo 93. Original Classroom No. 16 sign.

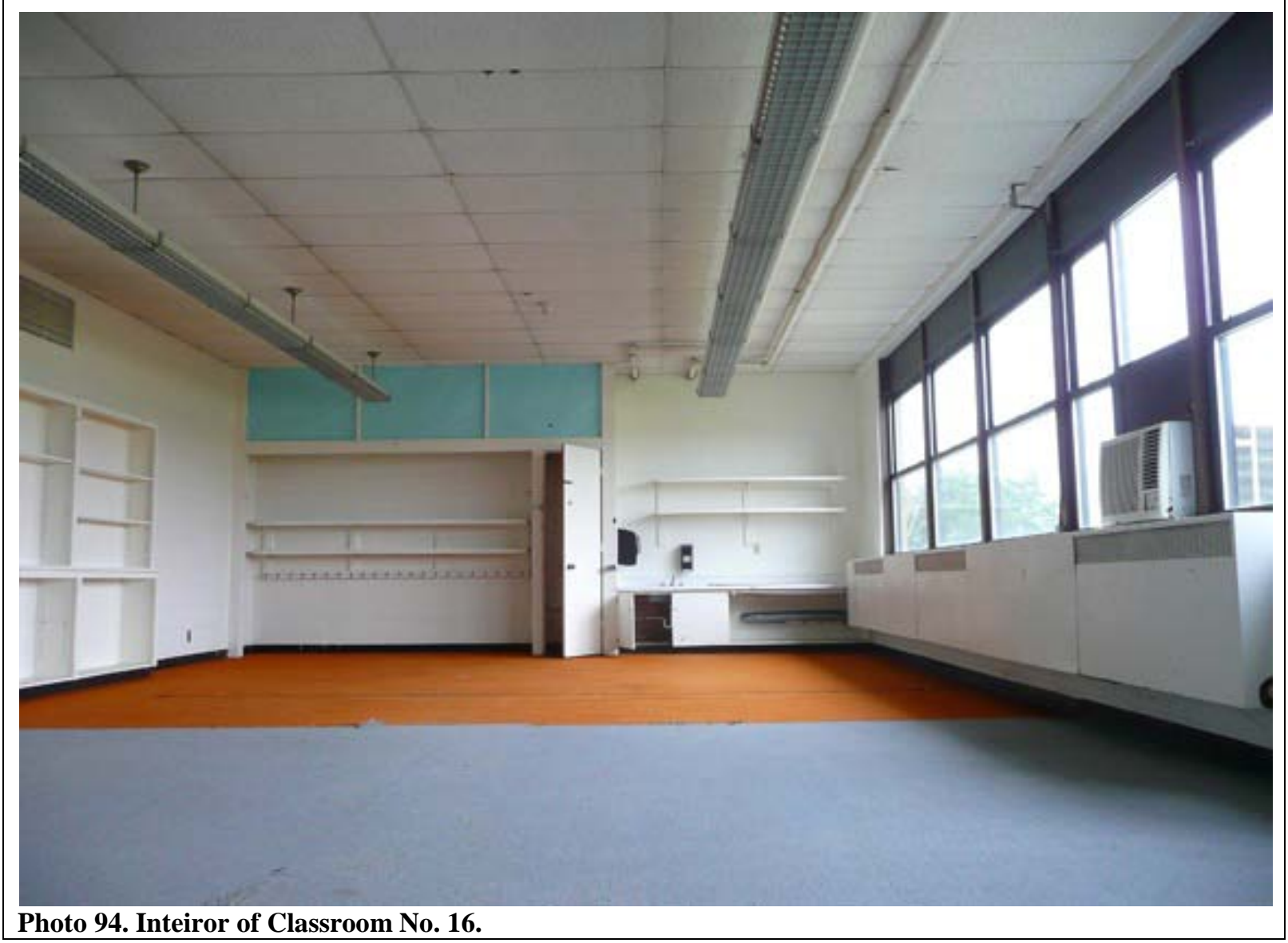




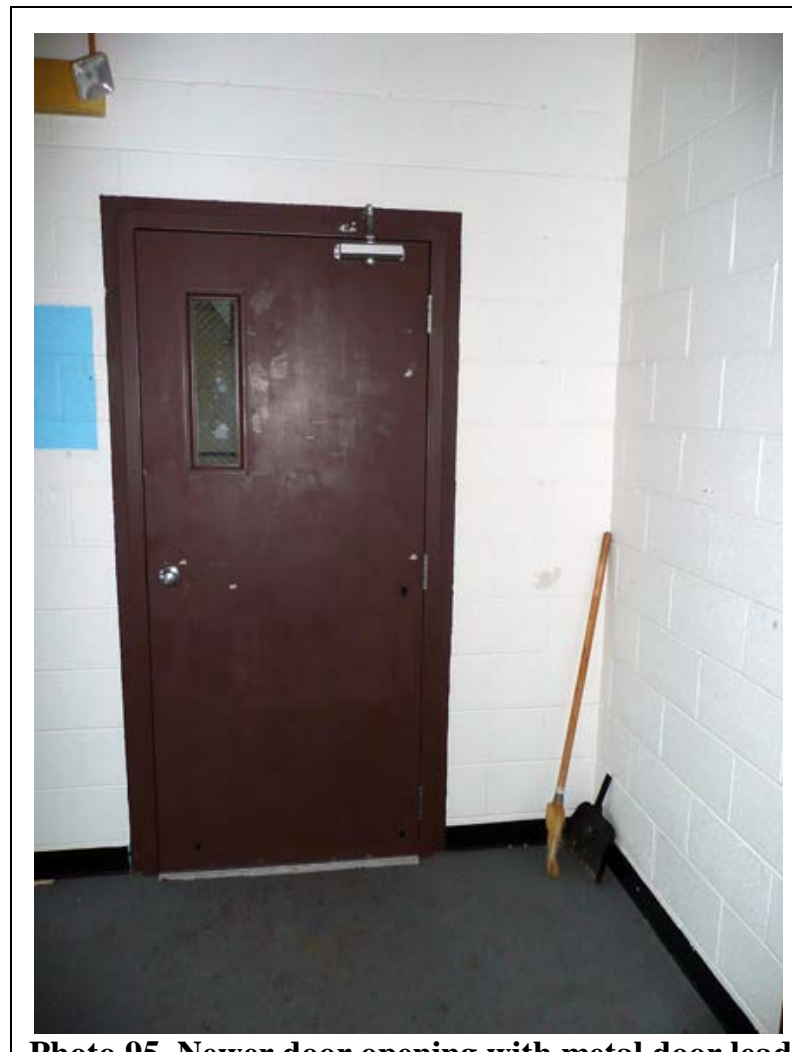

Photo 95. Newer door opening with metal door leading from Classroom No. 16 to Classroom No. 17.

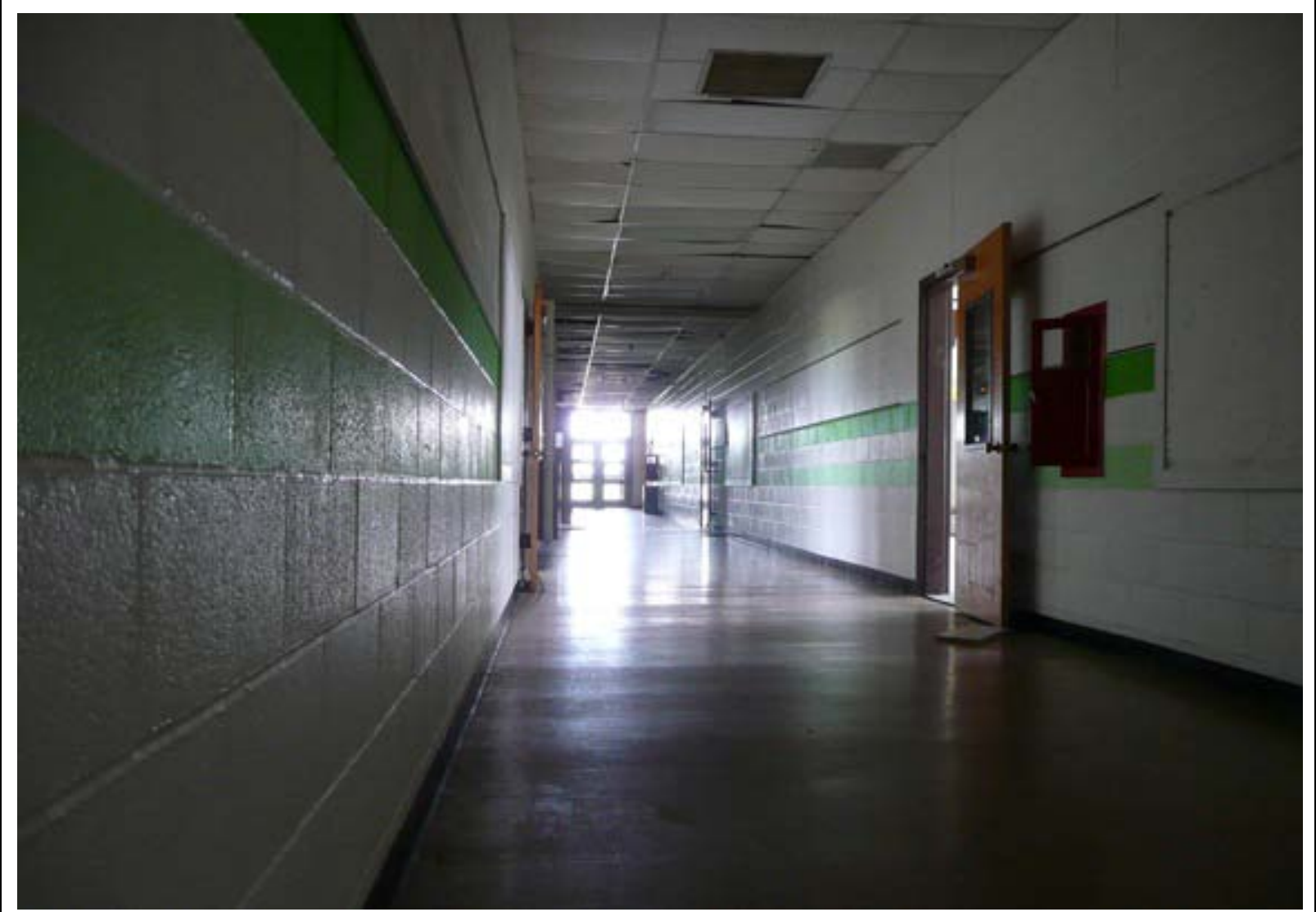

Photo 96. L ooking east in the corridor. 


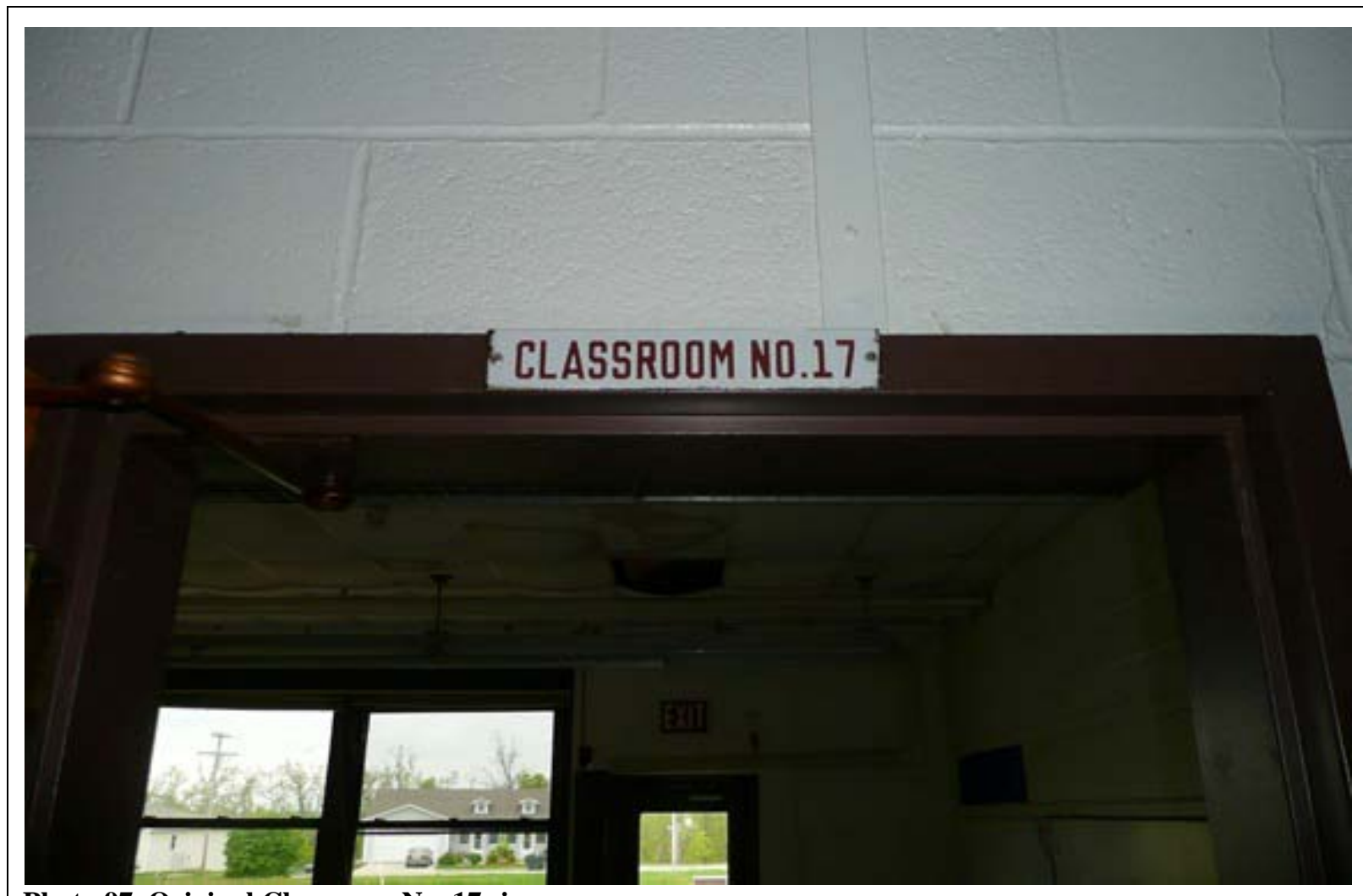

Photo 97. Original C lassroom No. 17 sign.

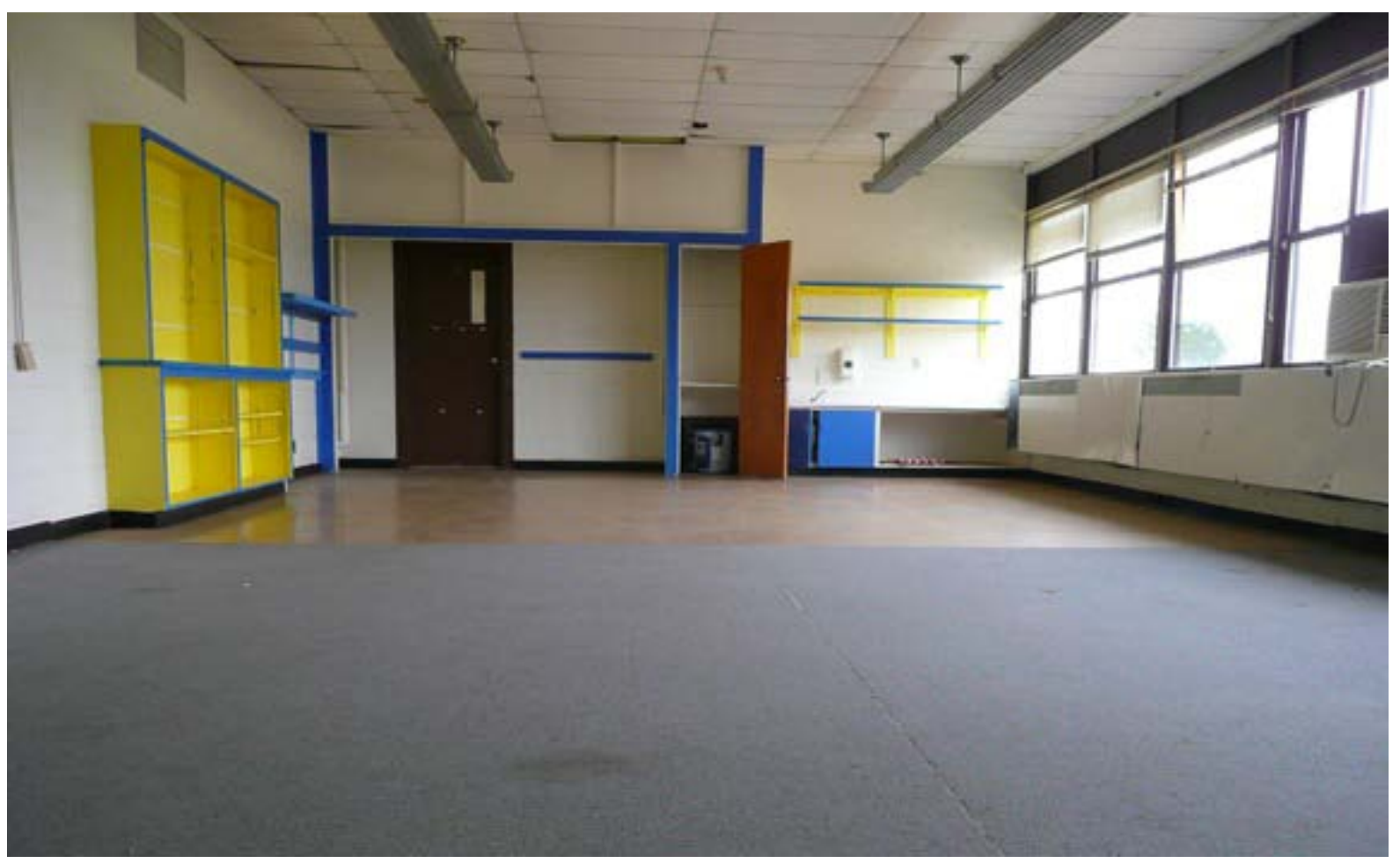

Photo 98. Interior of C lassroom No. 17 looking towards coat room and workstation. 


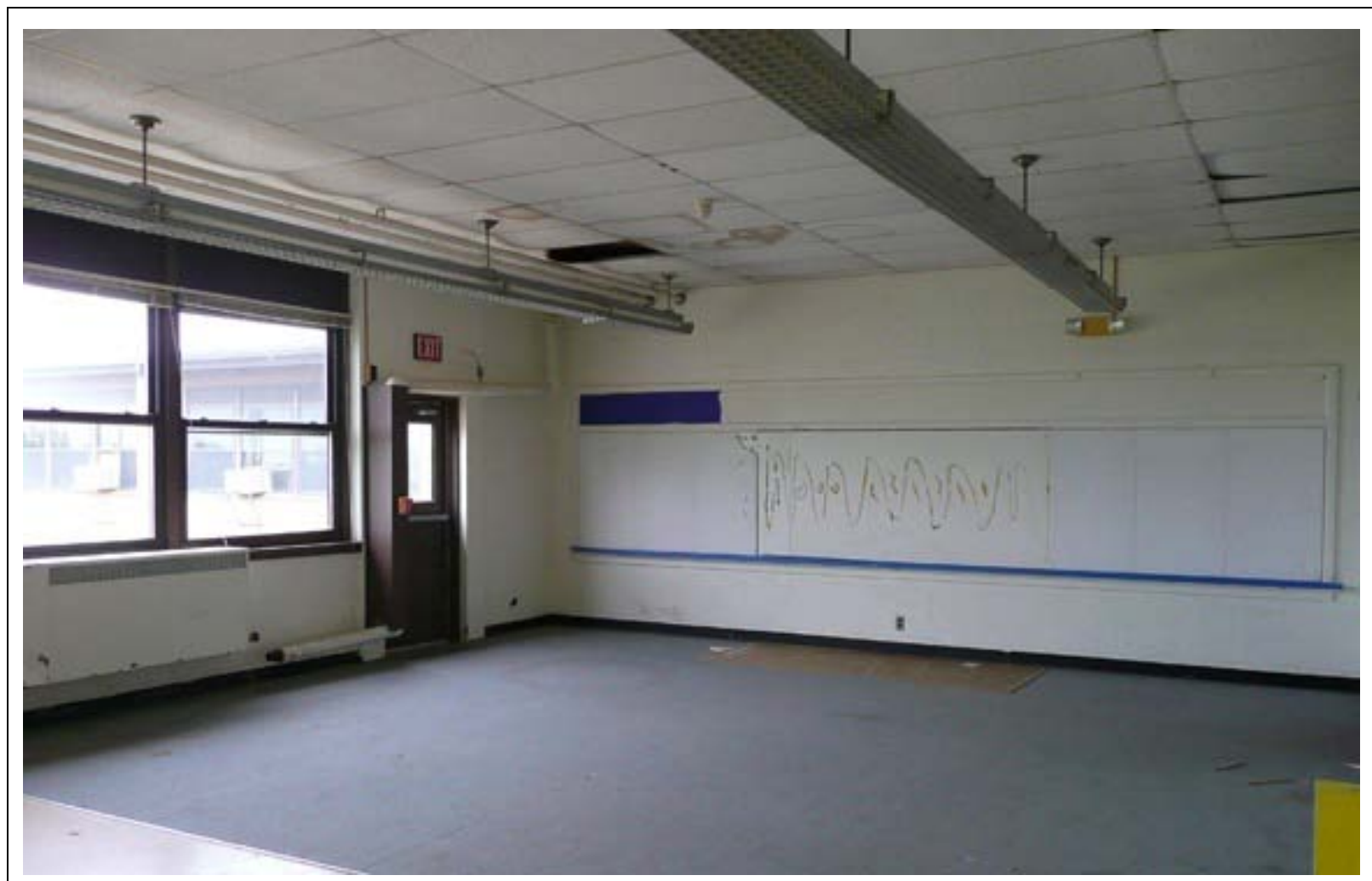

Photo 99. Interior of Classroom No. 17 looking towards modified chalkboard.

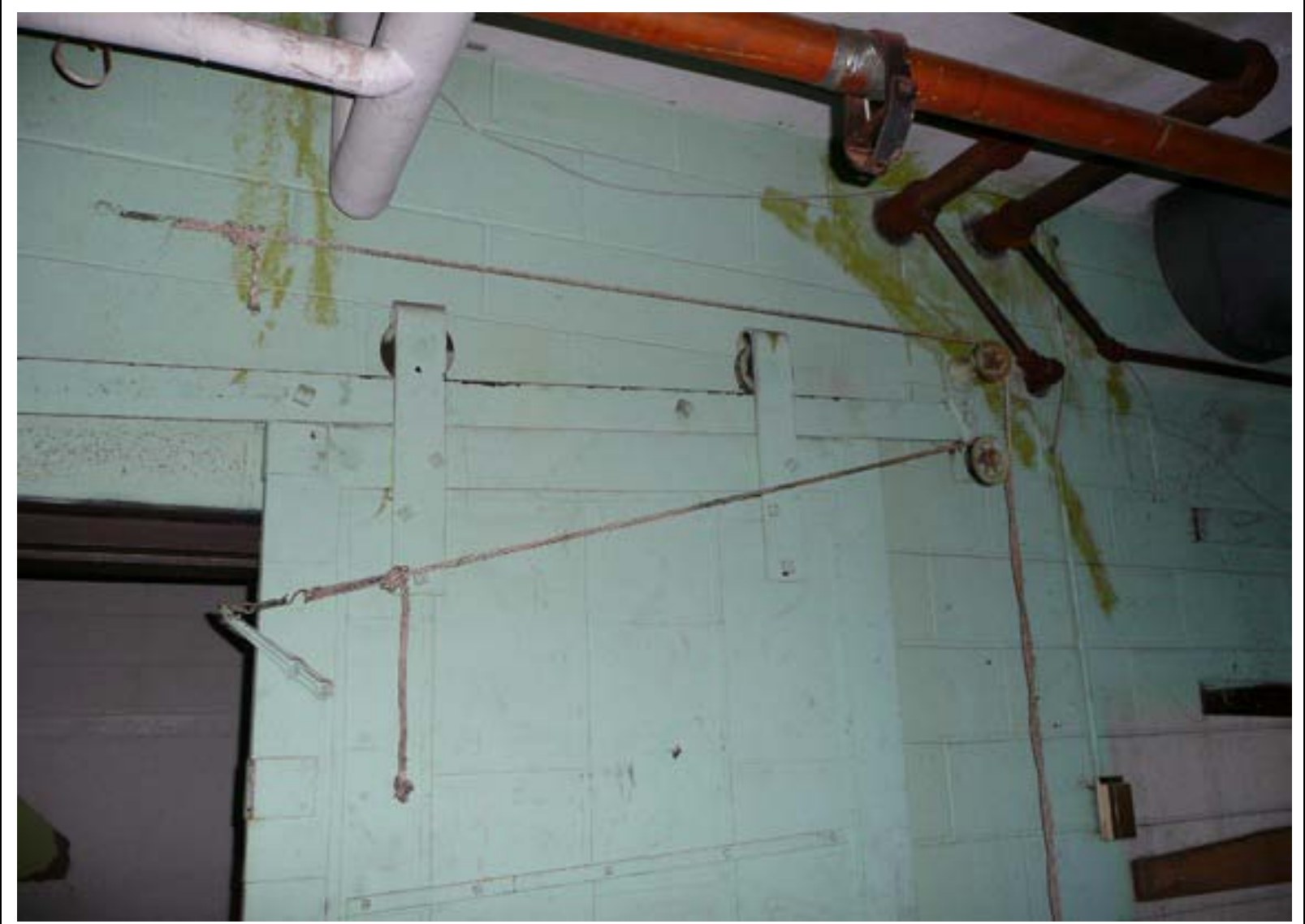

Photo 100. The original sliding track door leading into the boiler room. 


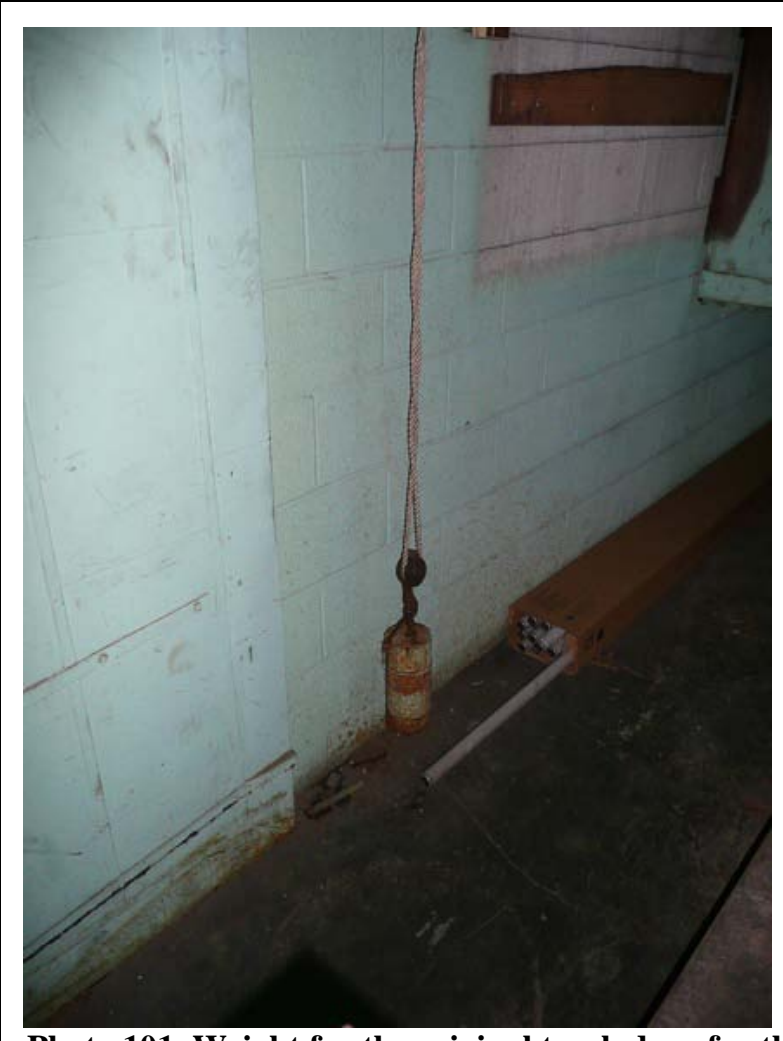

Photo 101. W eight for the original track door for the boiler room.

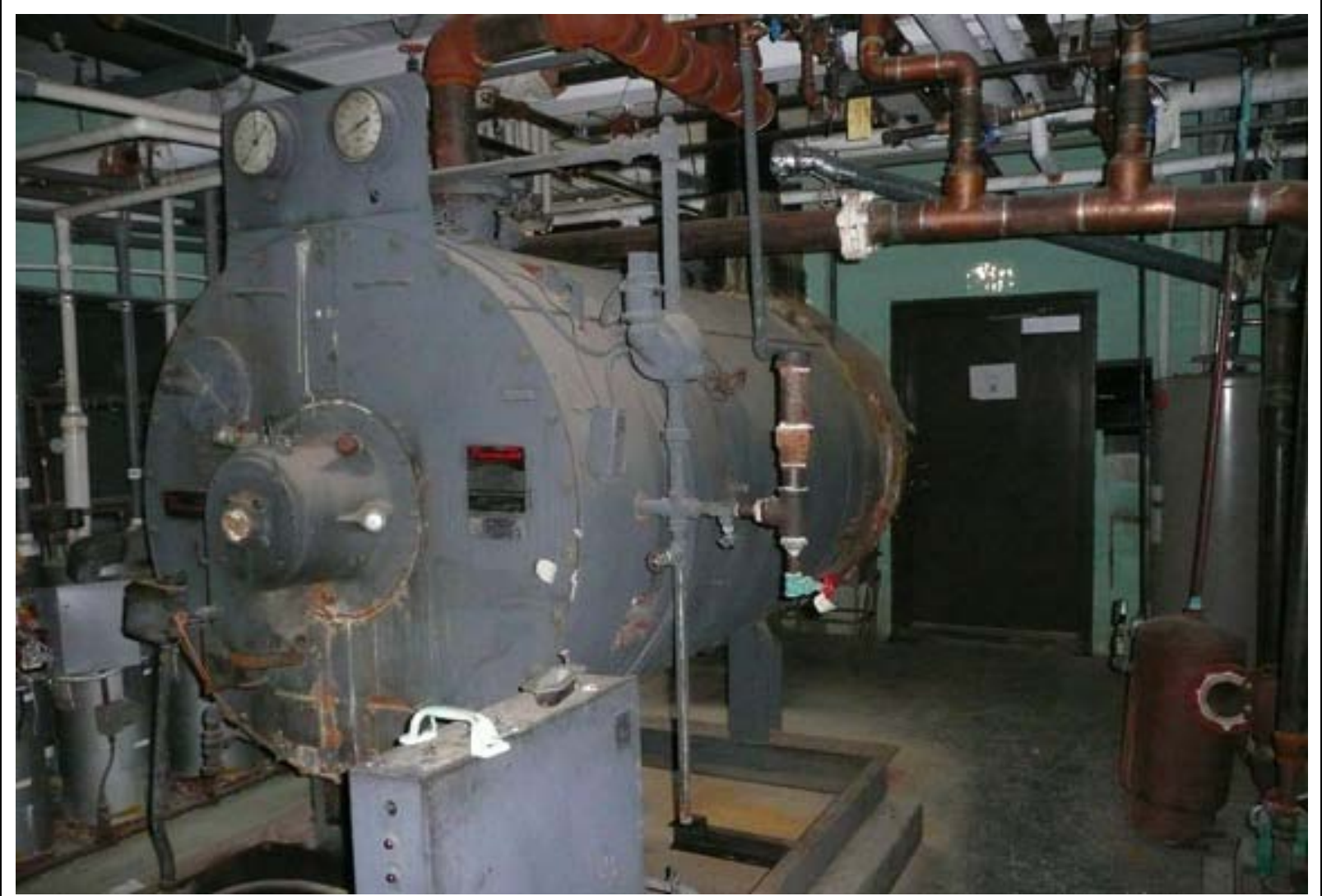

Photo 102. Interior of boiler room. 


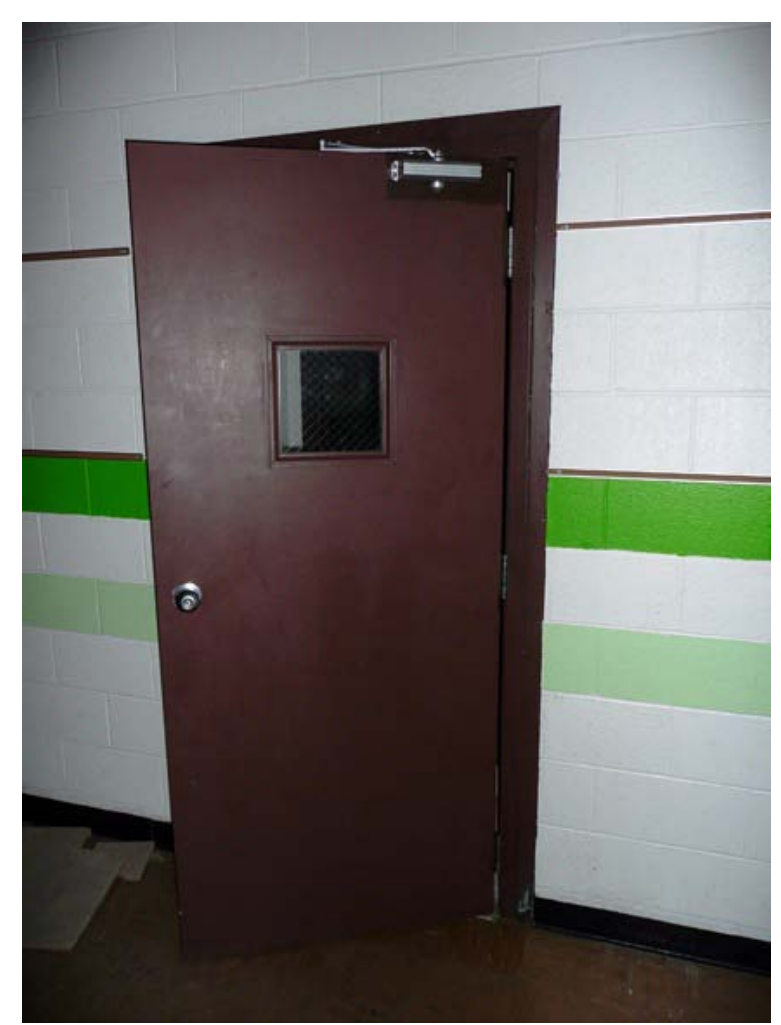

Photo 103. Newer metal door leading into the kitchen.

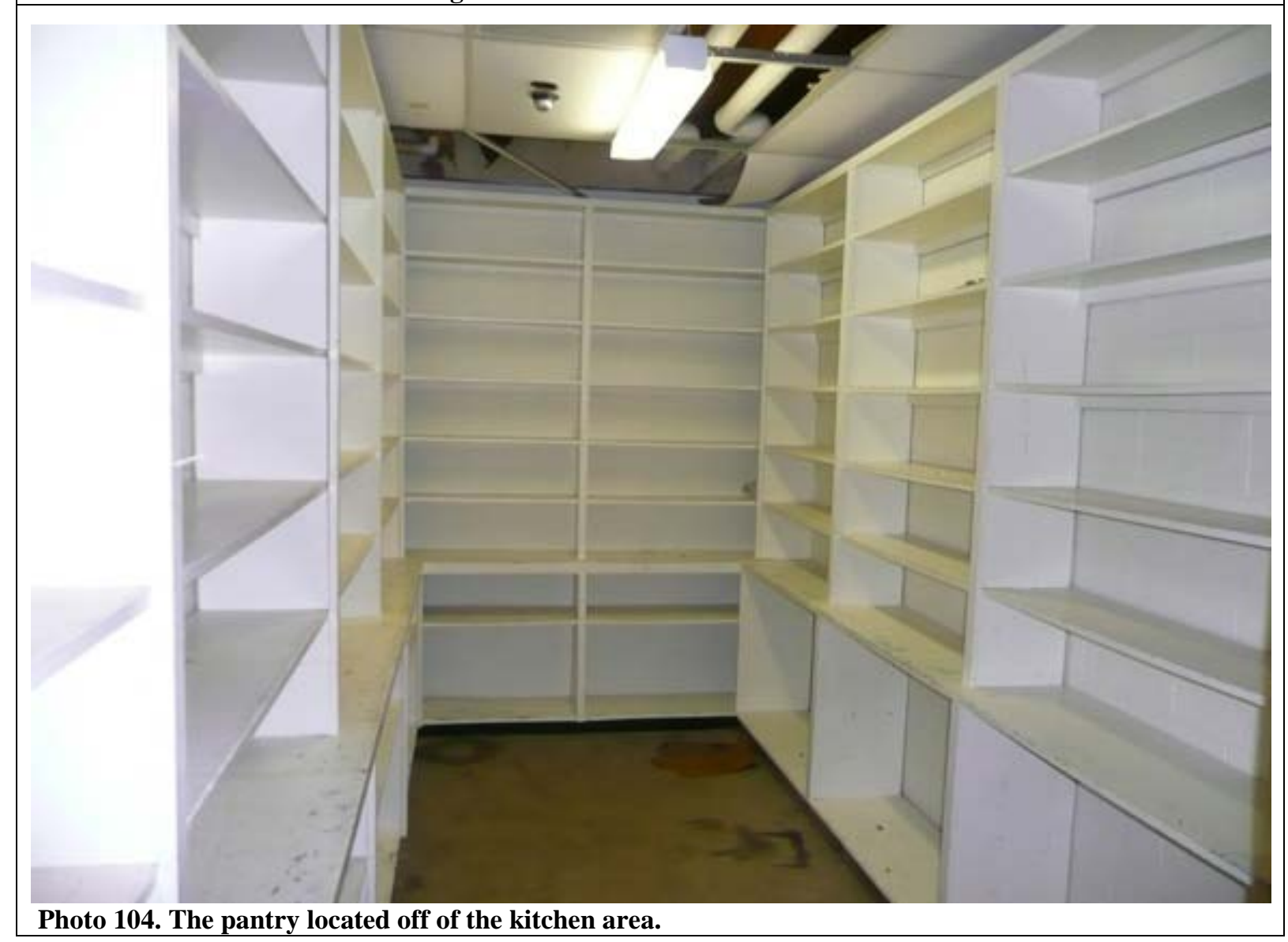




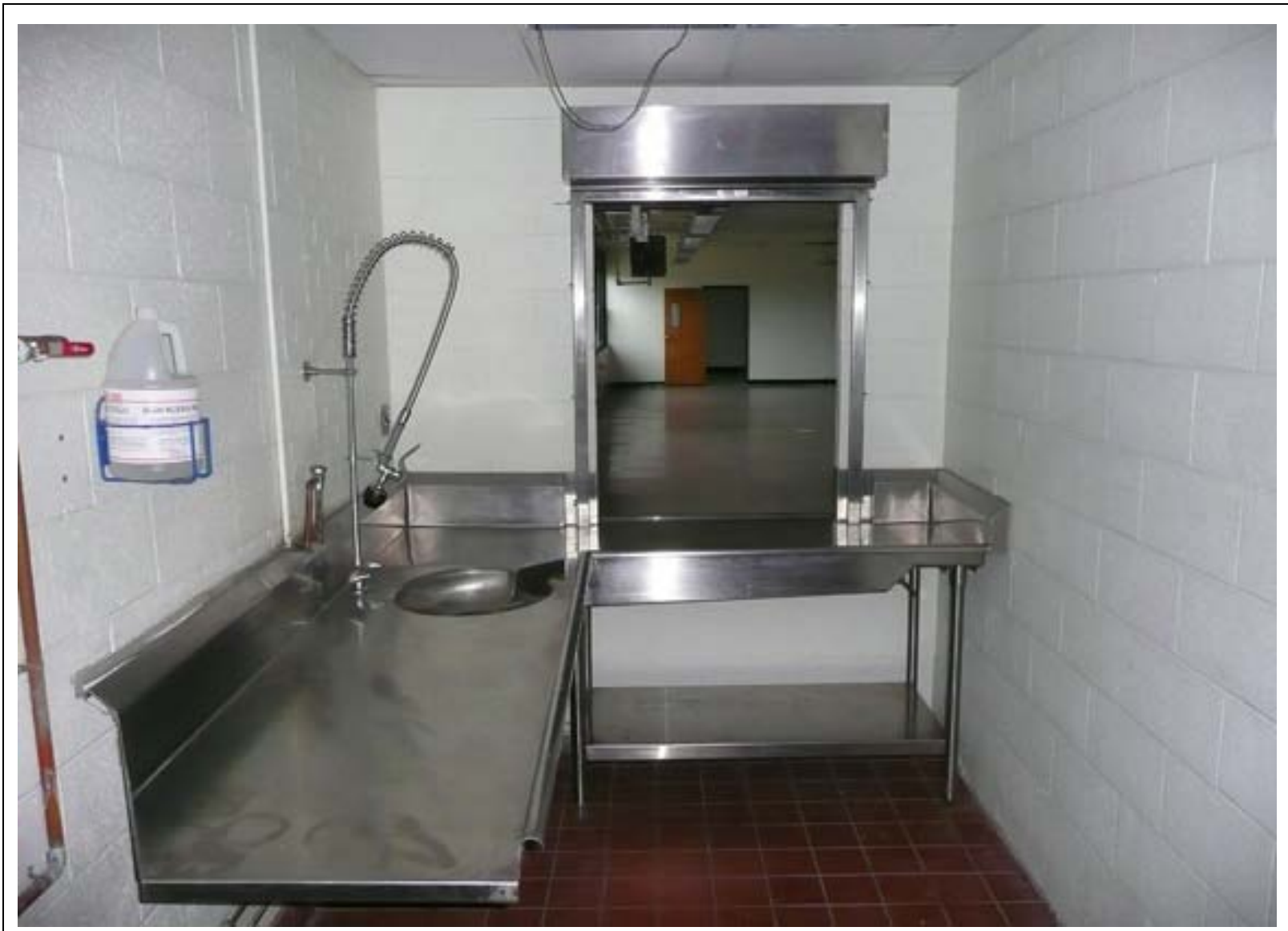

Photo 105. W ash station in the kitchen.

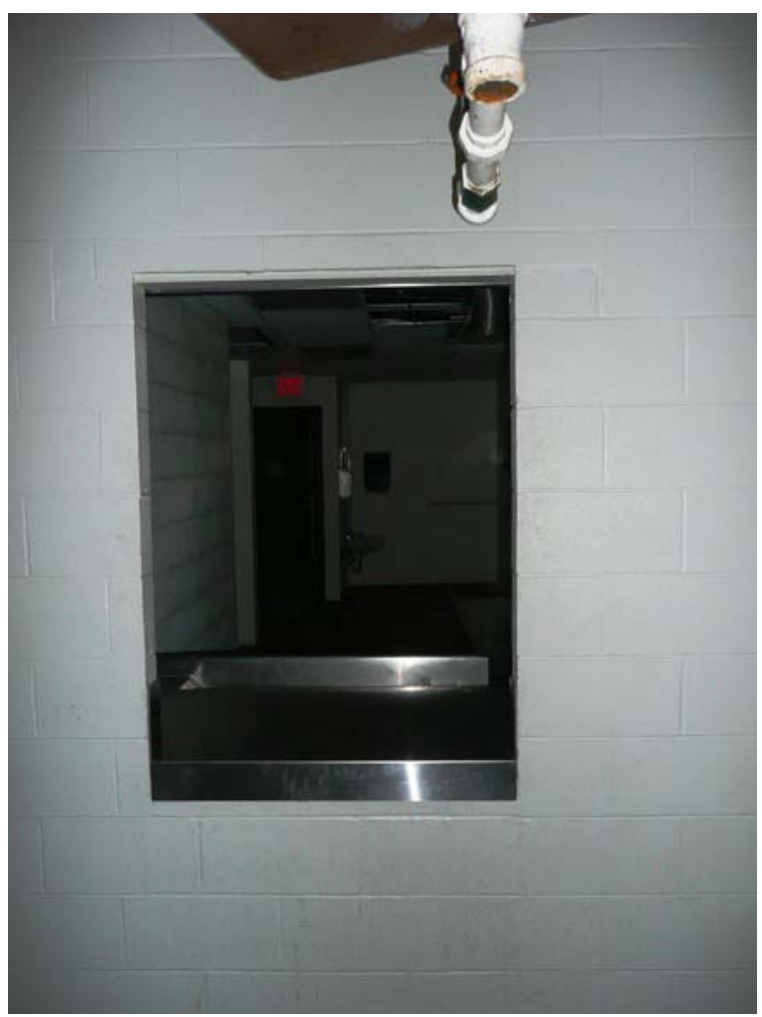




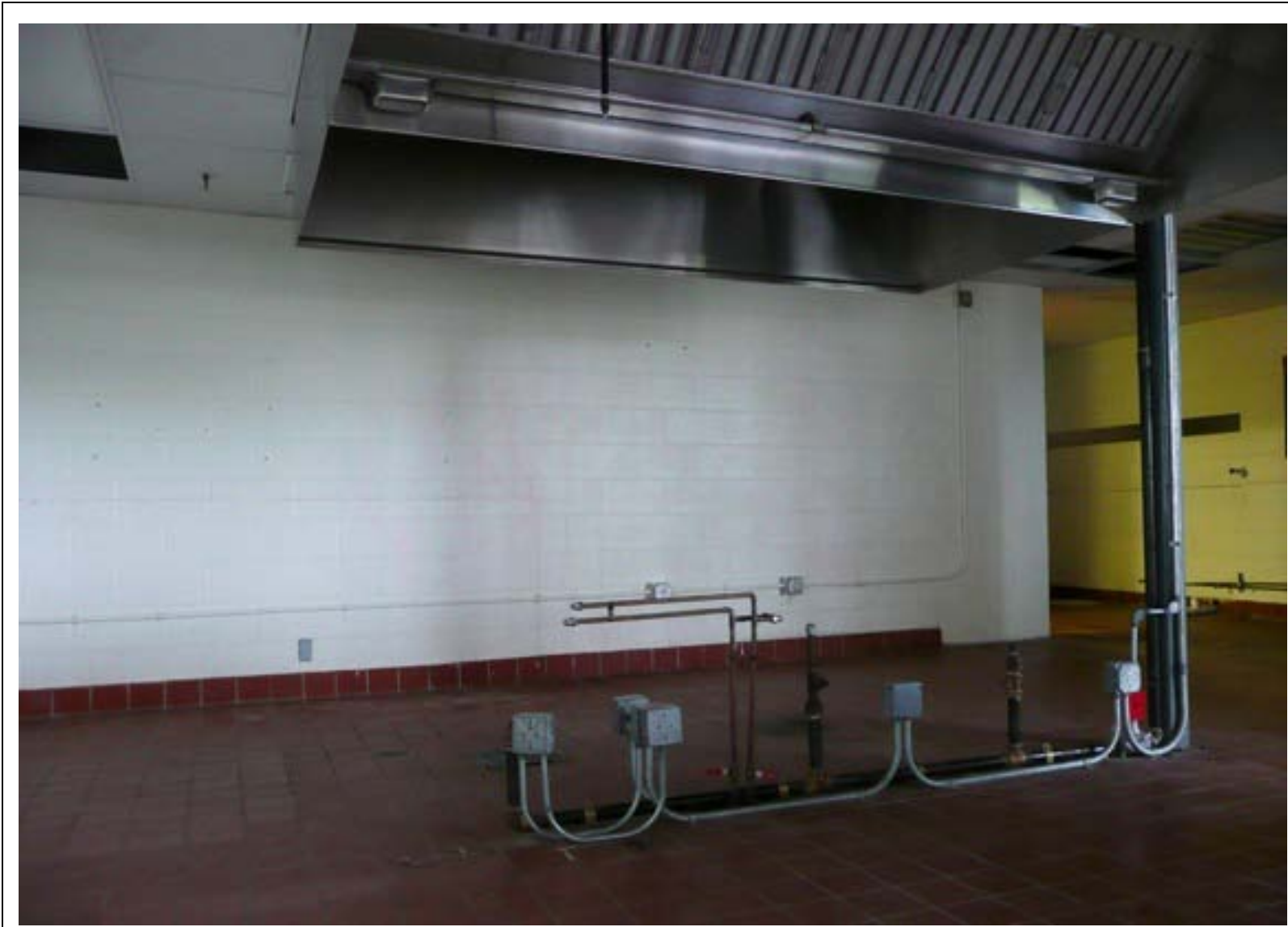

Photo 107. C ooking area in the kitchen with all appliance removed.

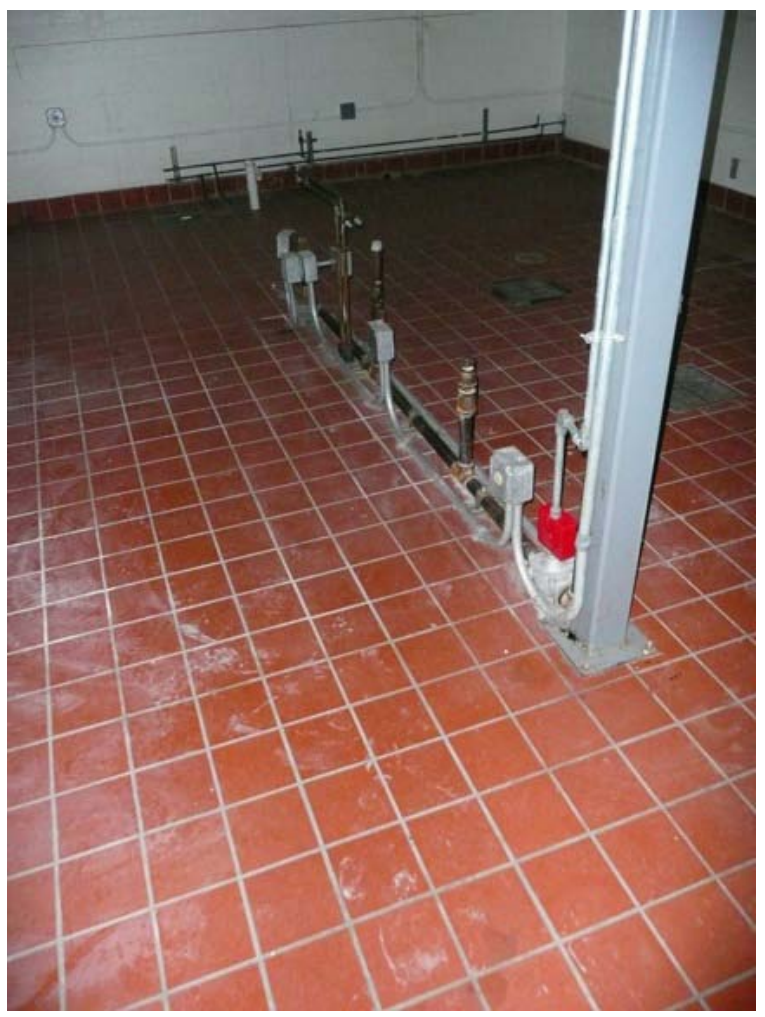

Photo 108. Original clay tile floor in the cooking area of the kitchen. 


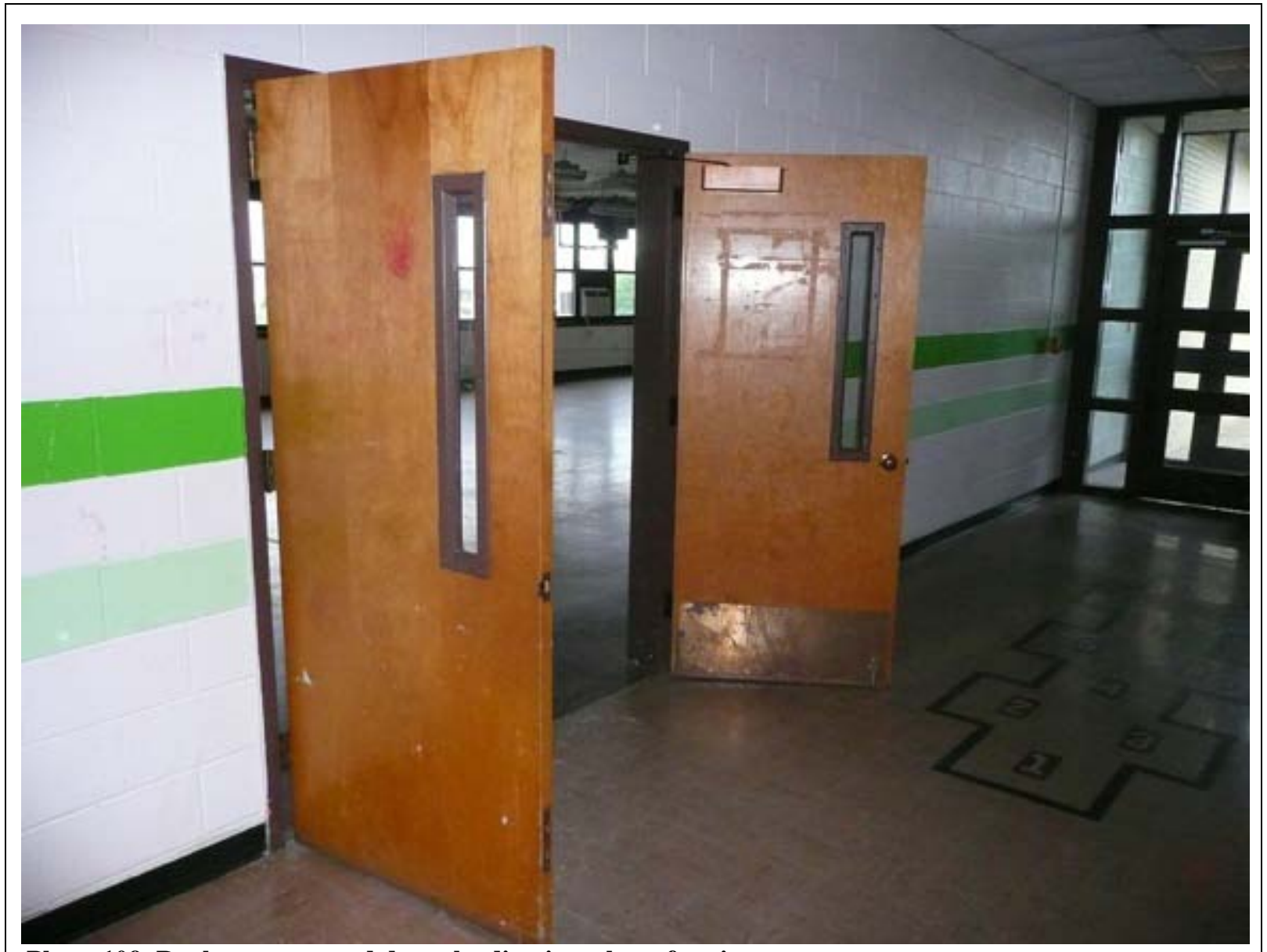

Photo 109. Replacement wood doors leading into the cafeteria.

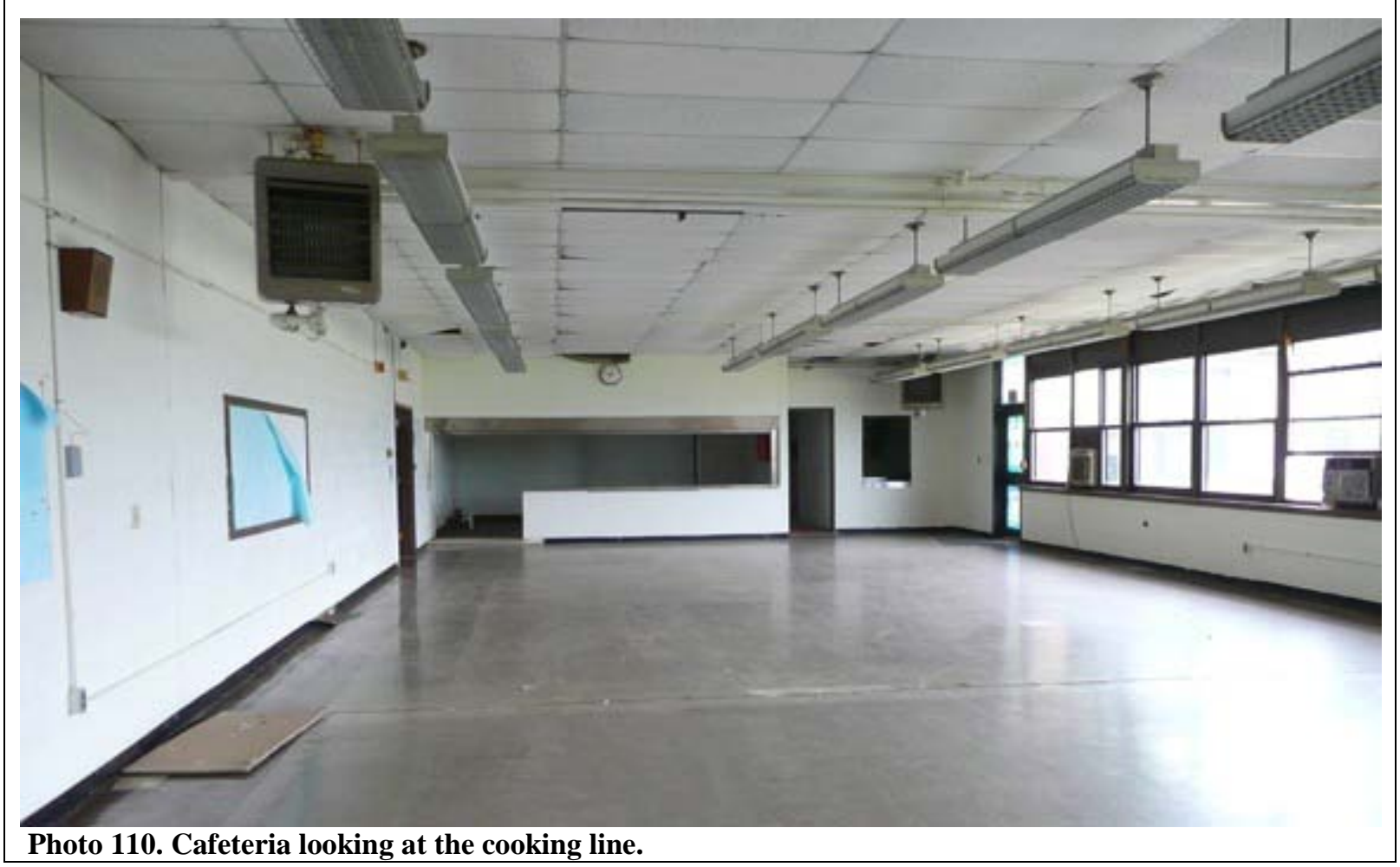




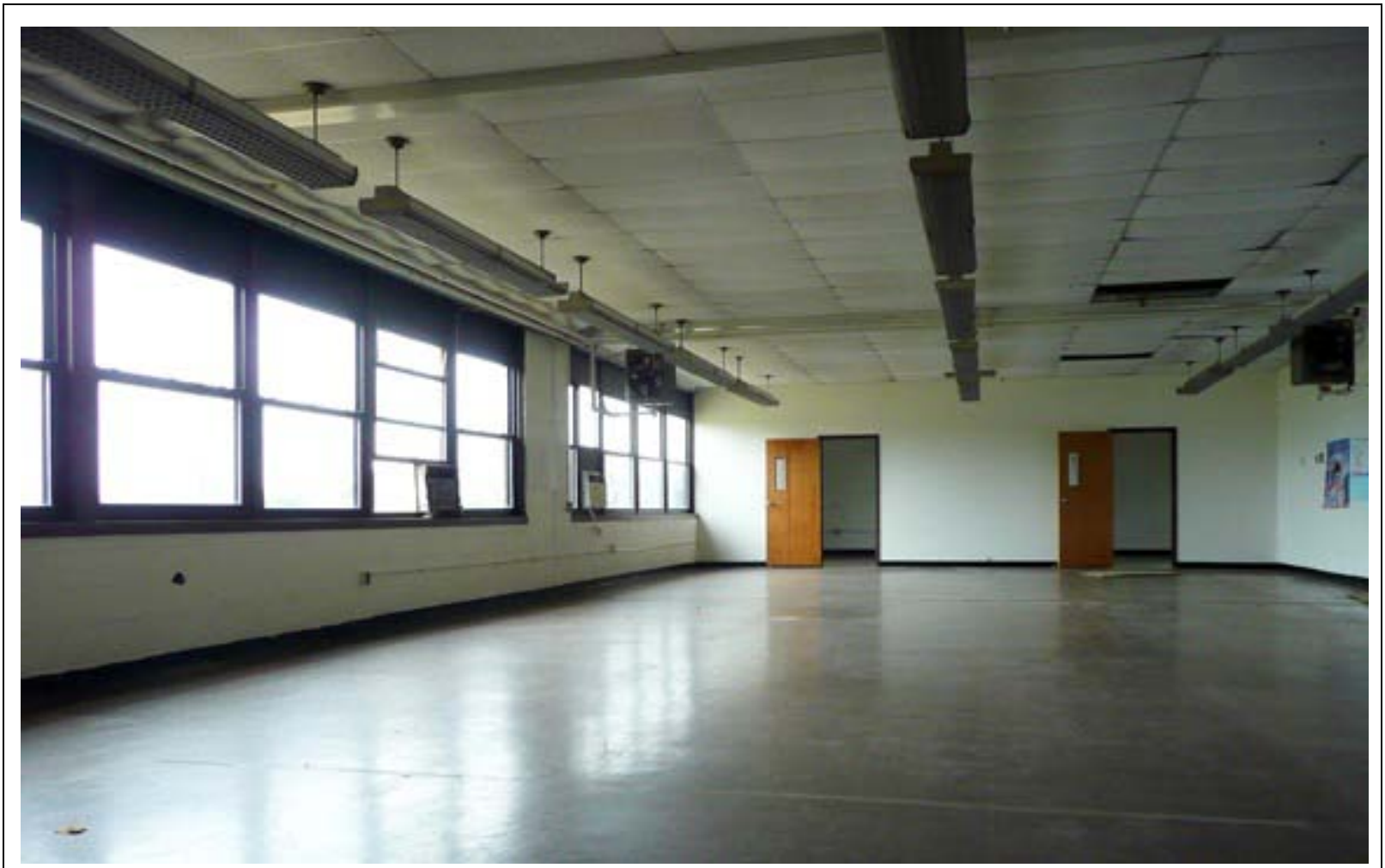

Photo 111. C afeteria looking towards the newer addition located on the south end of the original cafeteria. 


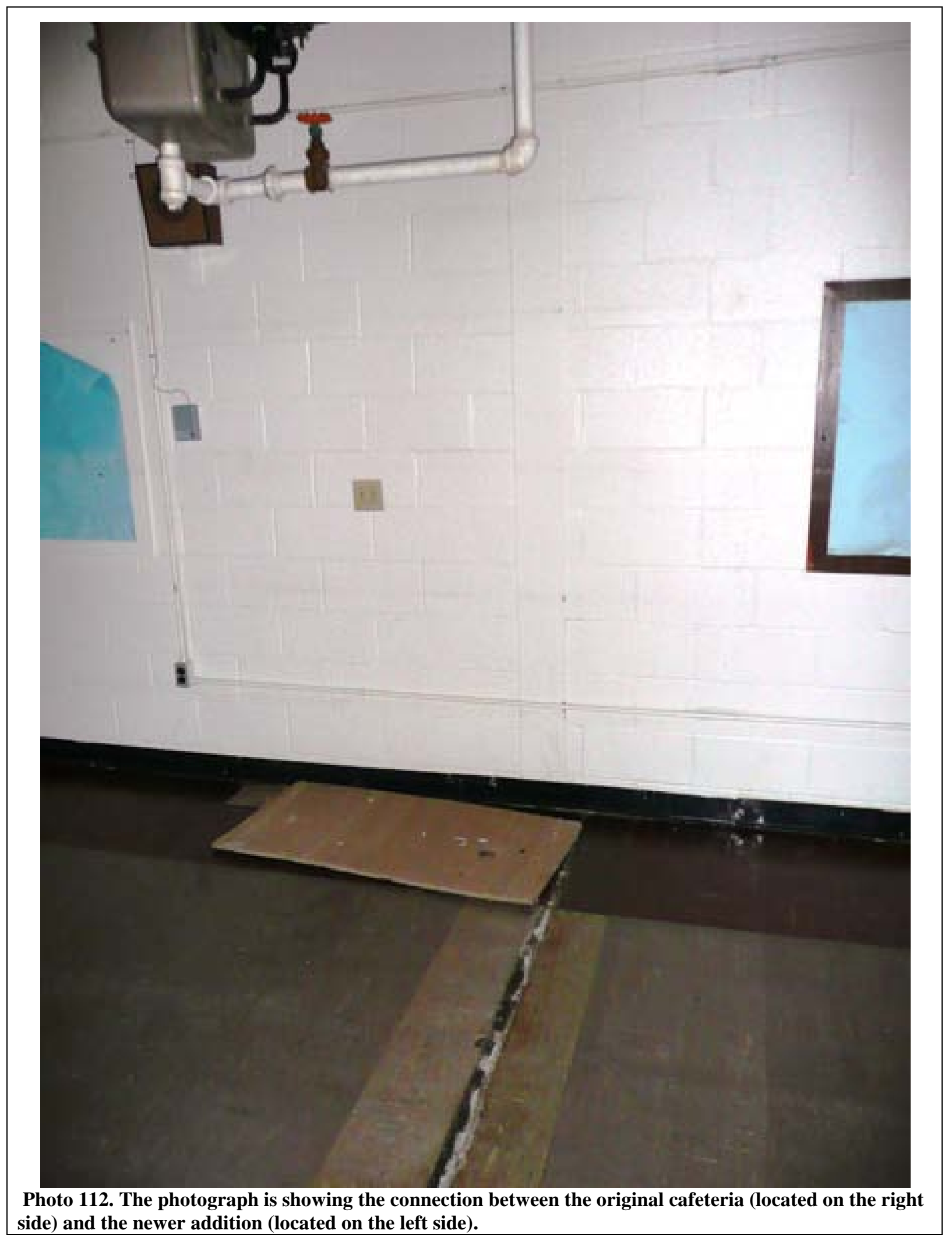




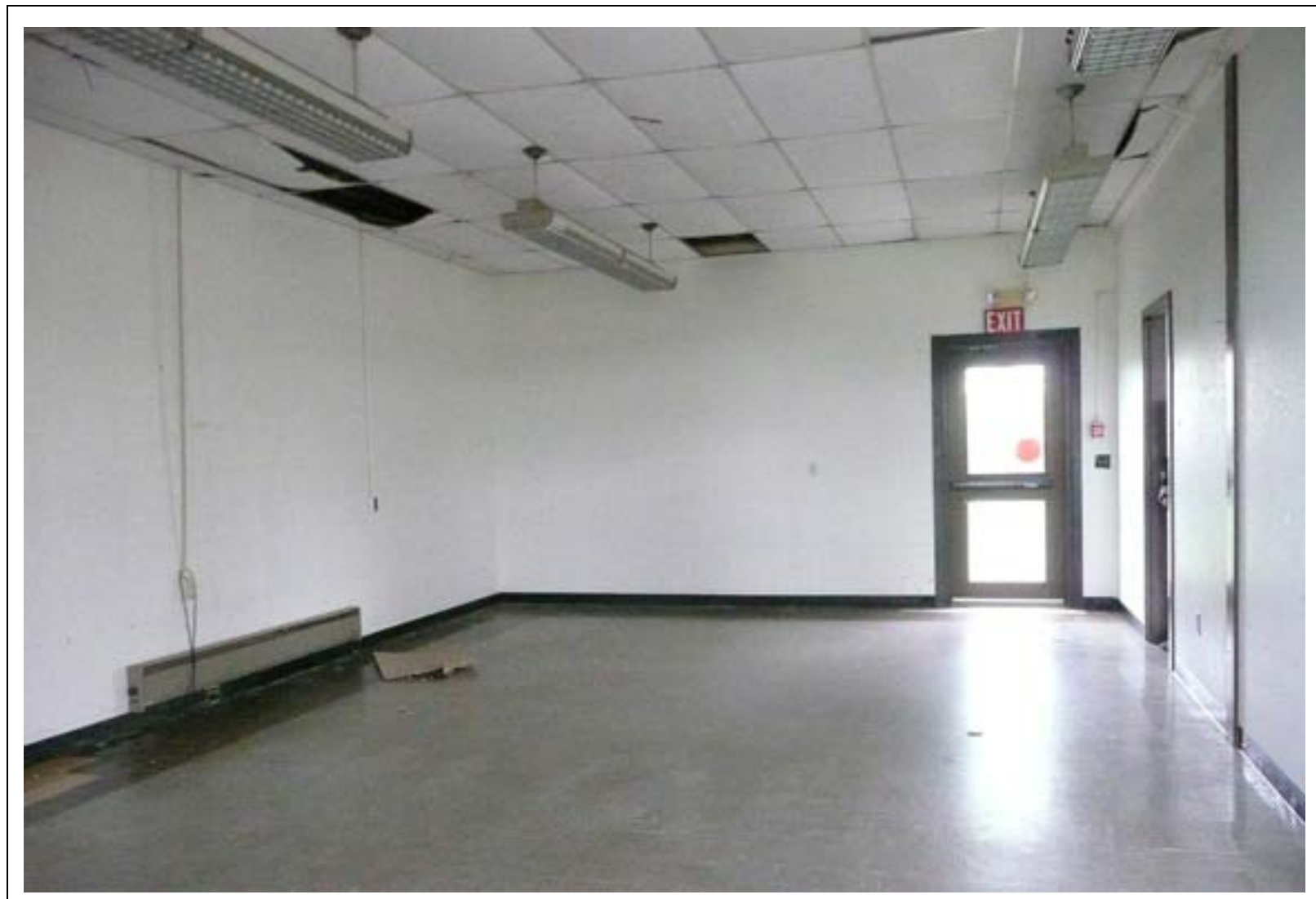

Photo 113. Newer addition of the cafeteria located to the south side of the original cafeteria.

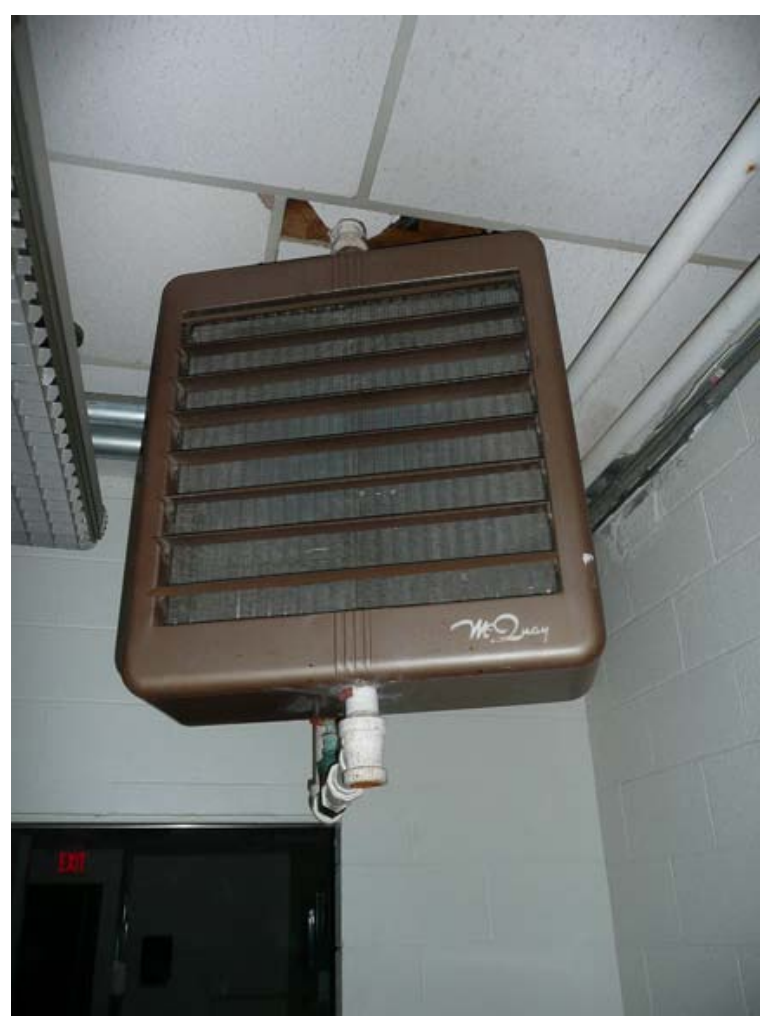

Photo 114. Radiator located in the cafeteria. 


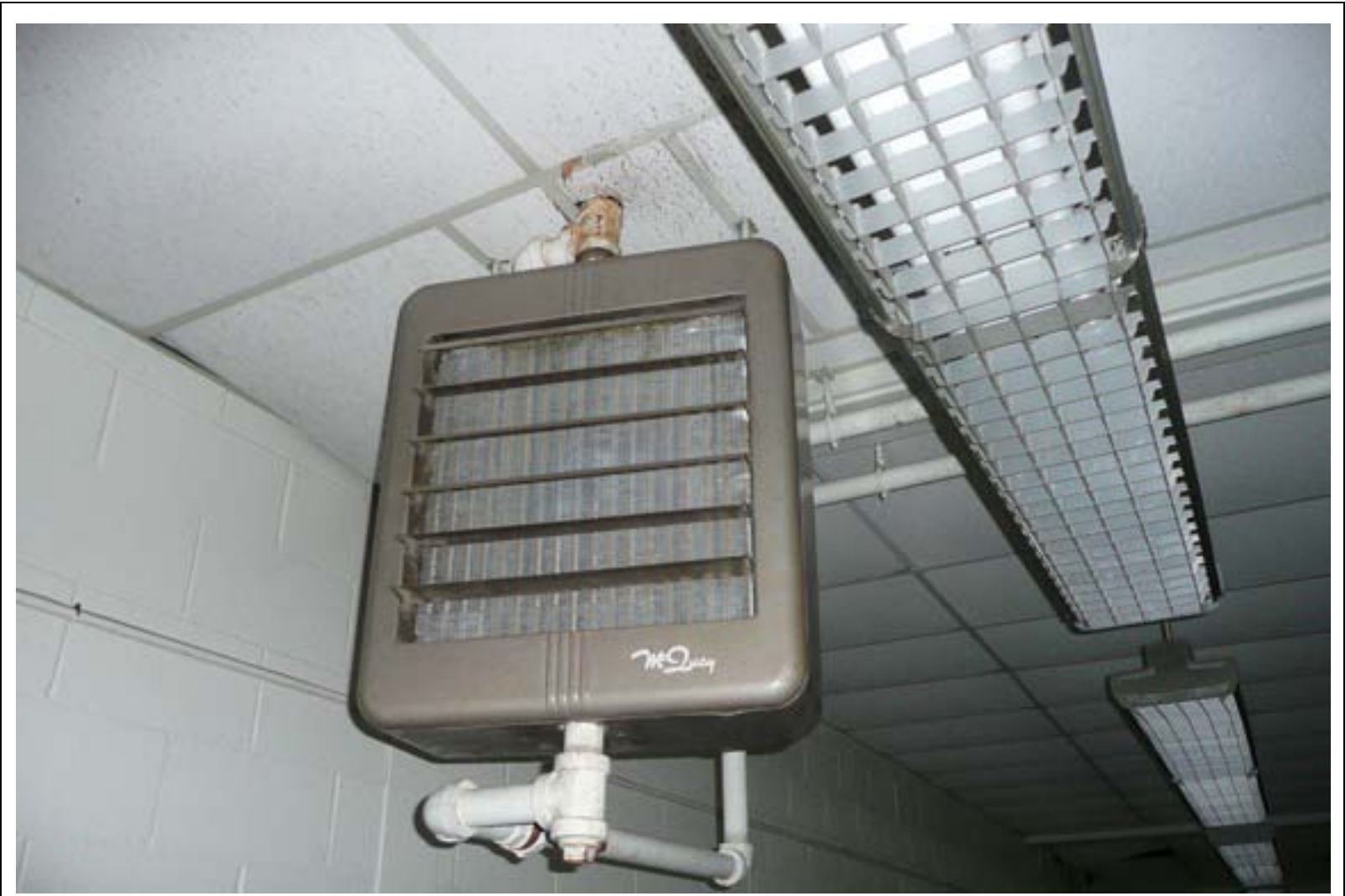

Photo 115. Radiator located in the cafeteria.

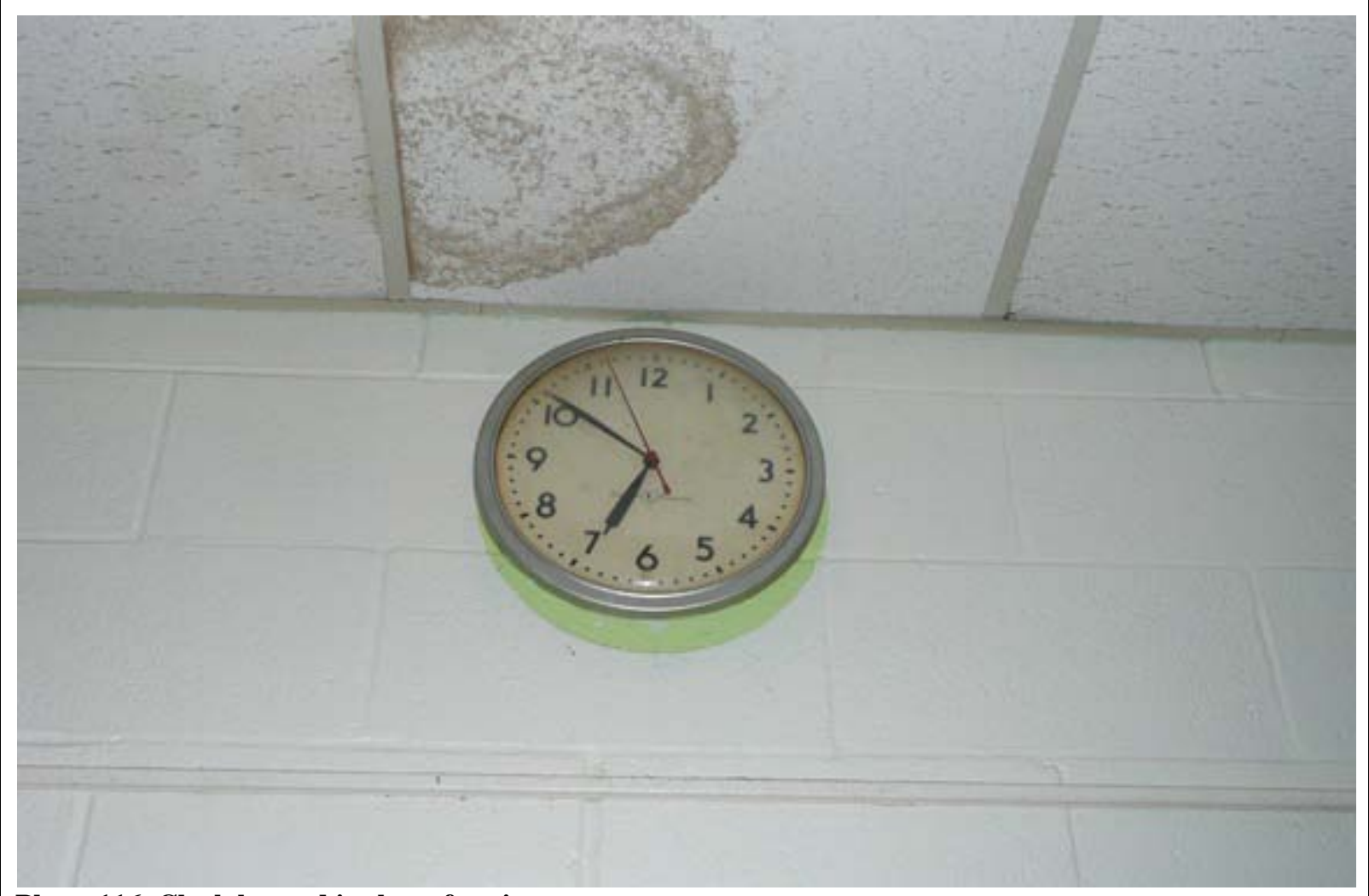

Photo 116. Clock located in the cafeteria. 

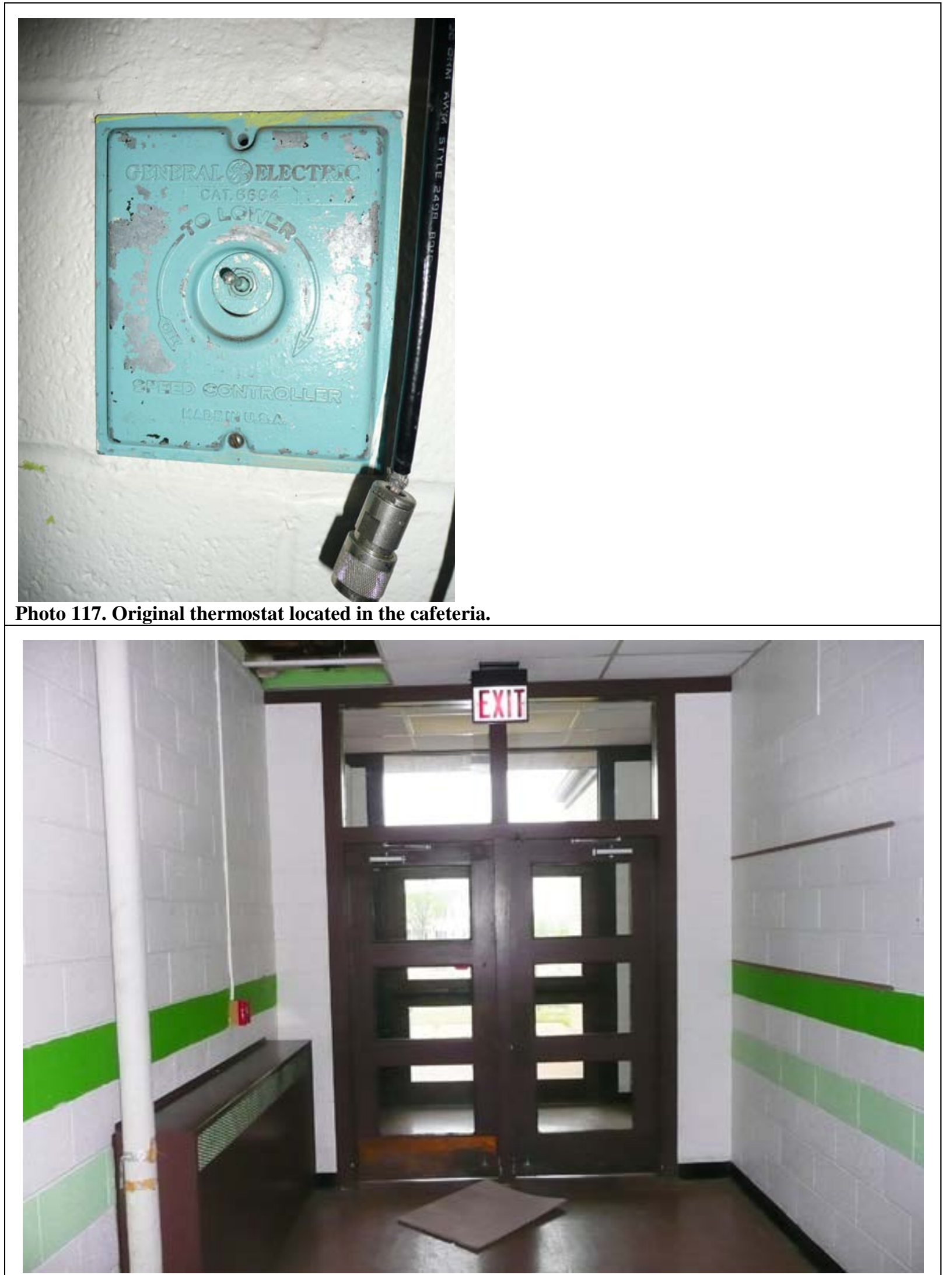

Photo 118. Original metal vestibule doors and transom located on the south end of the corridor near the cafeteria. 


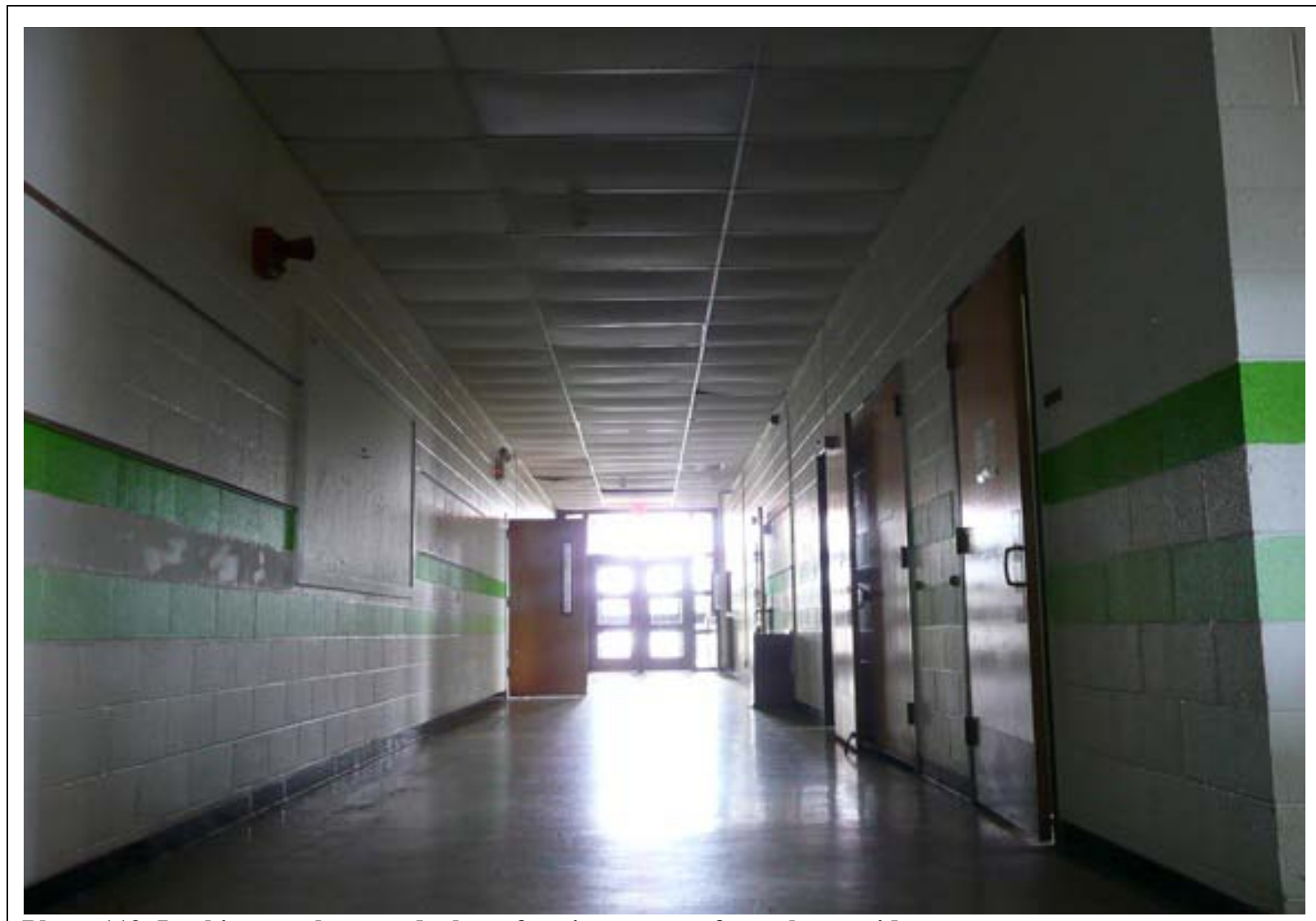

Photo 119. L ooking south towards the cafeteria entrance from the corridor.

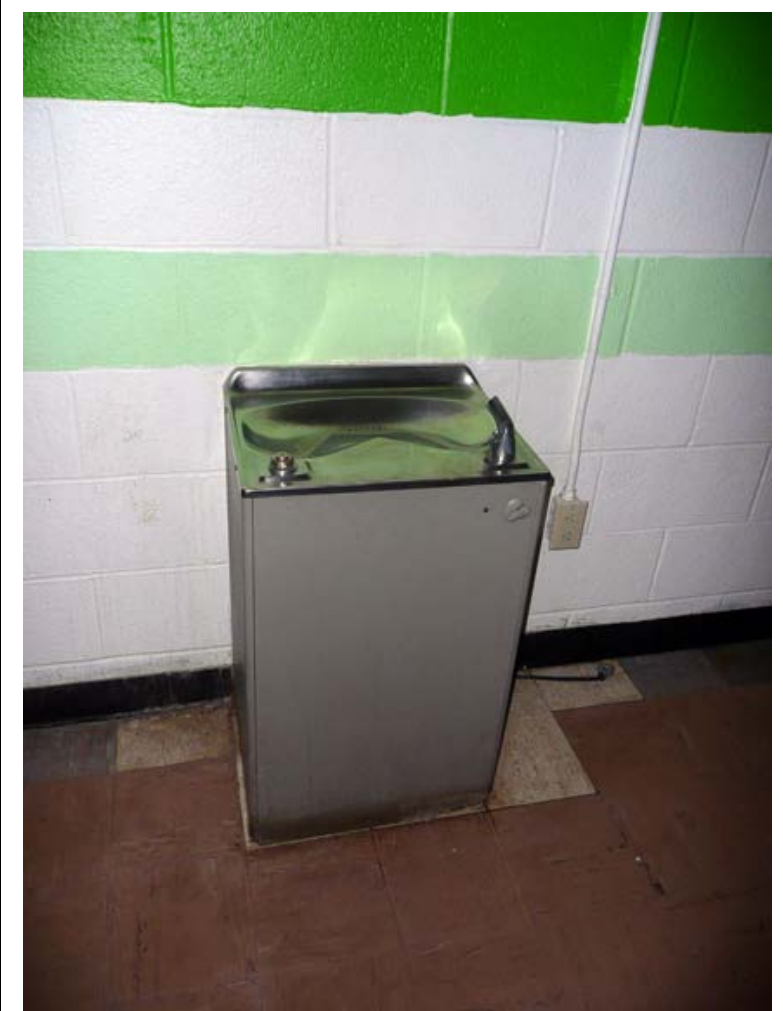




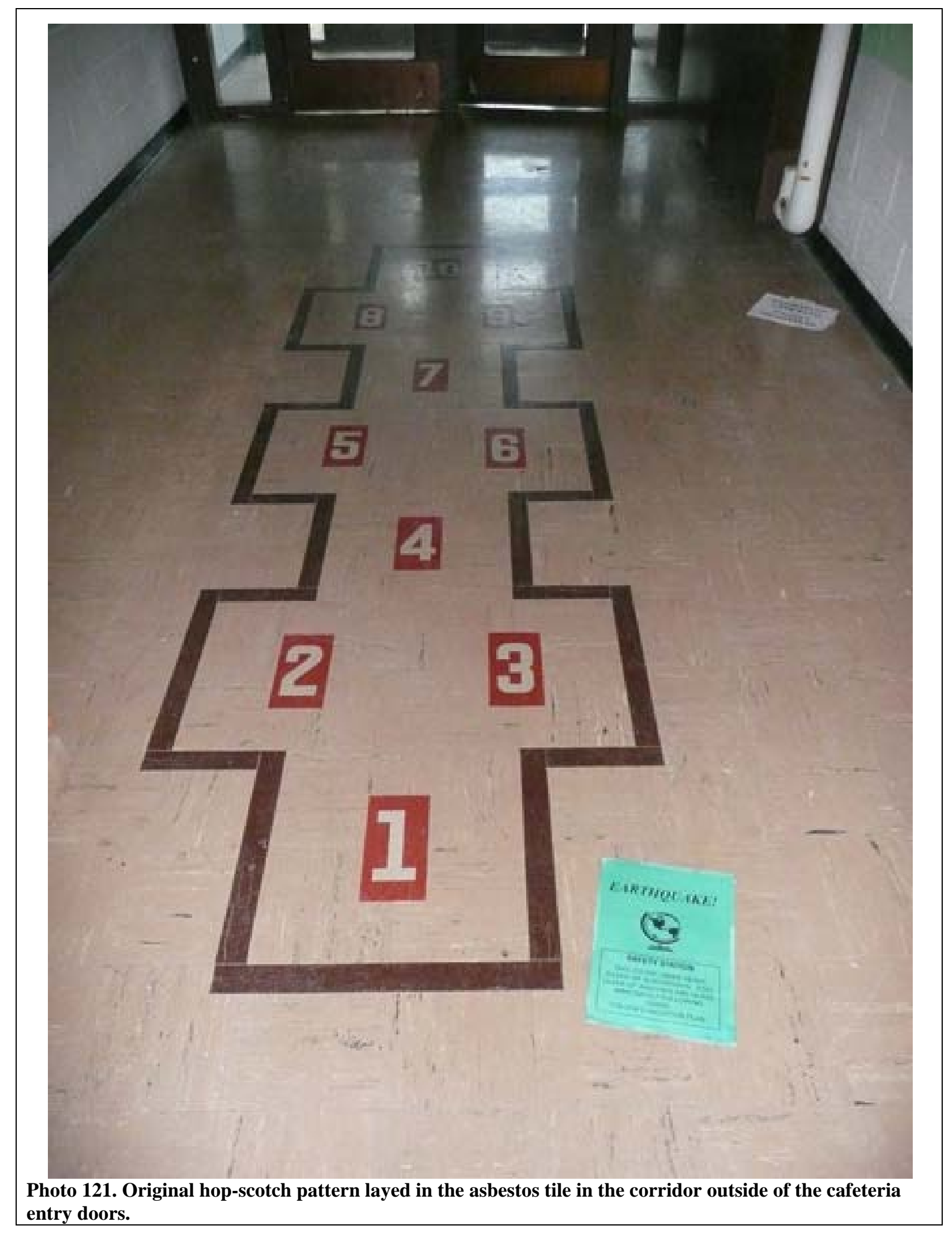




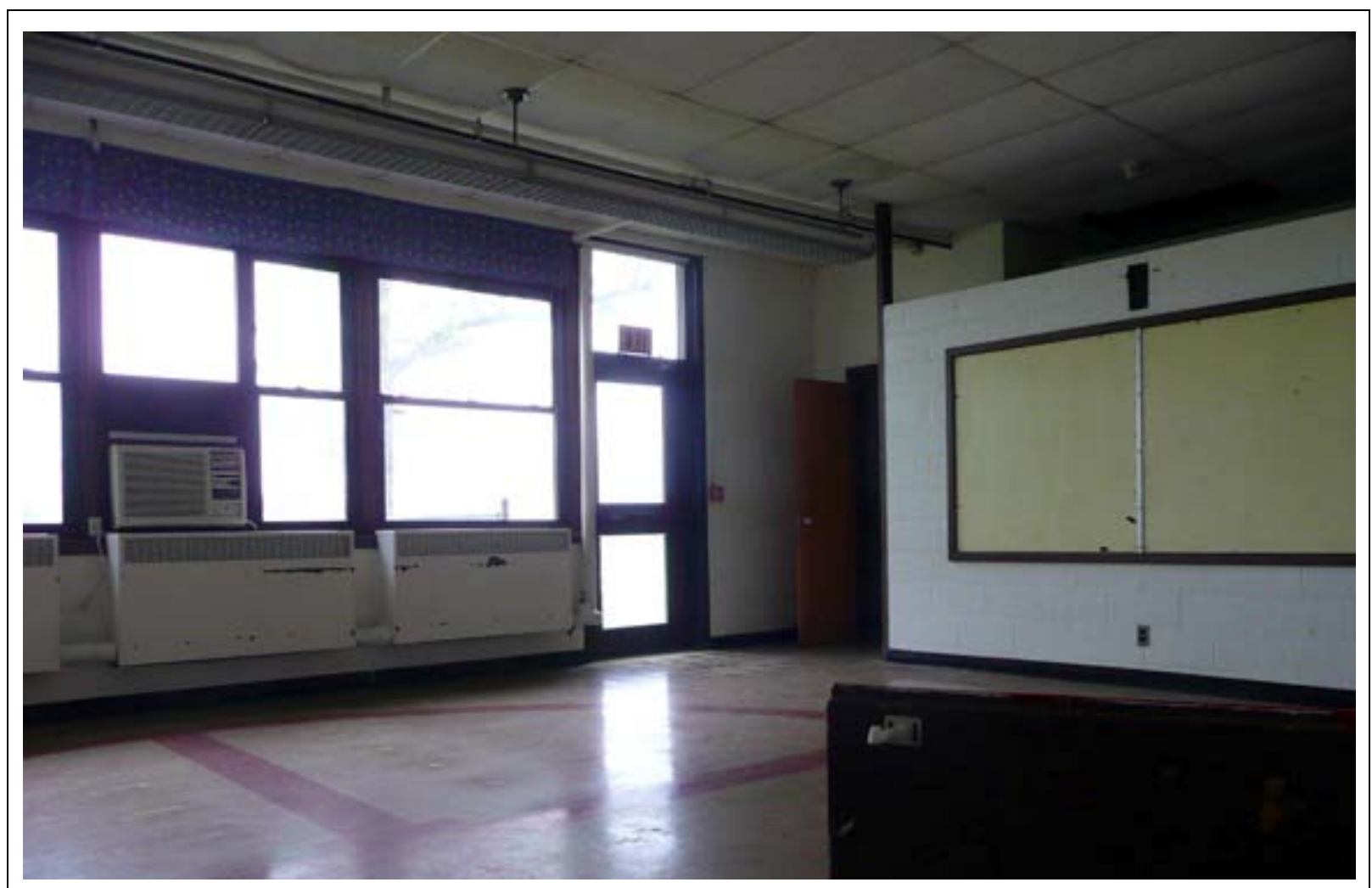

Photo 122. Interior of Primary R oom No. 23.

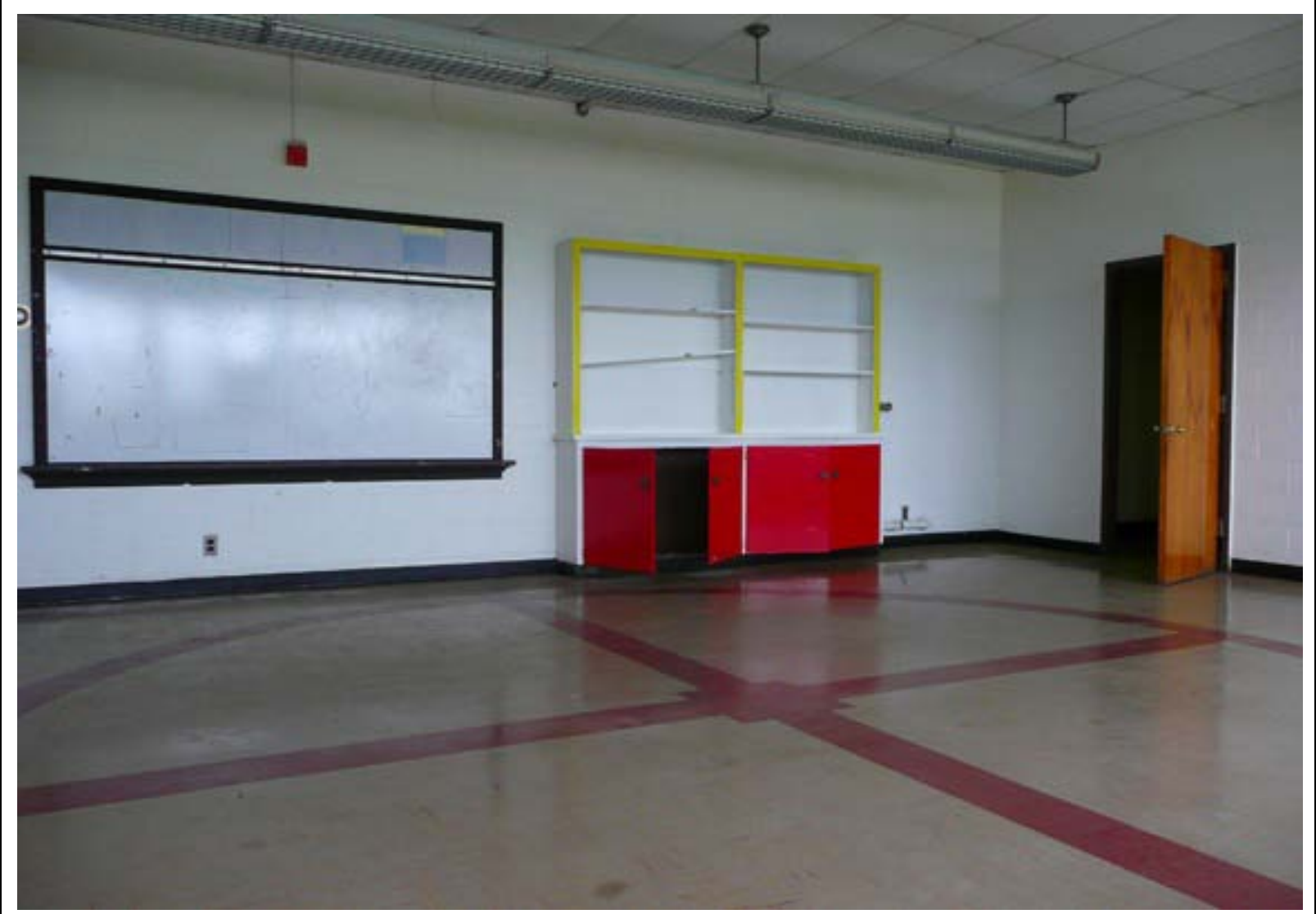

Photo 123. Inteiror of Primary R oom No. 23. 


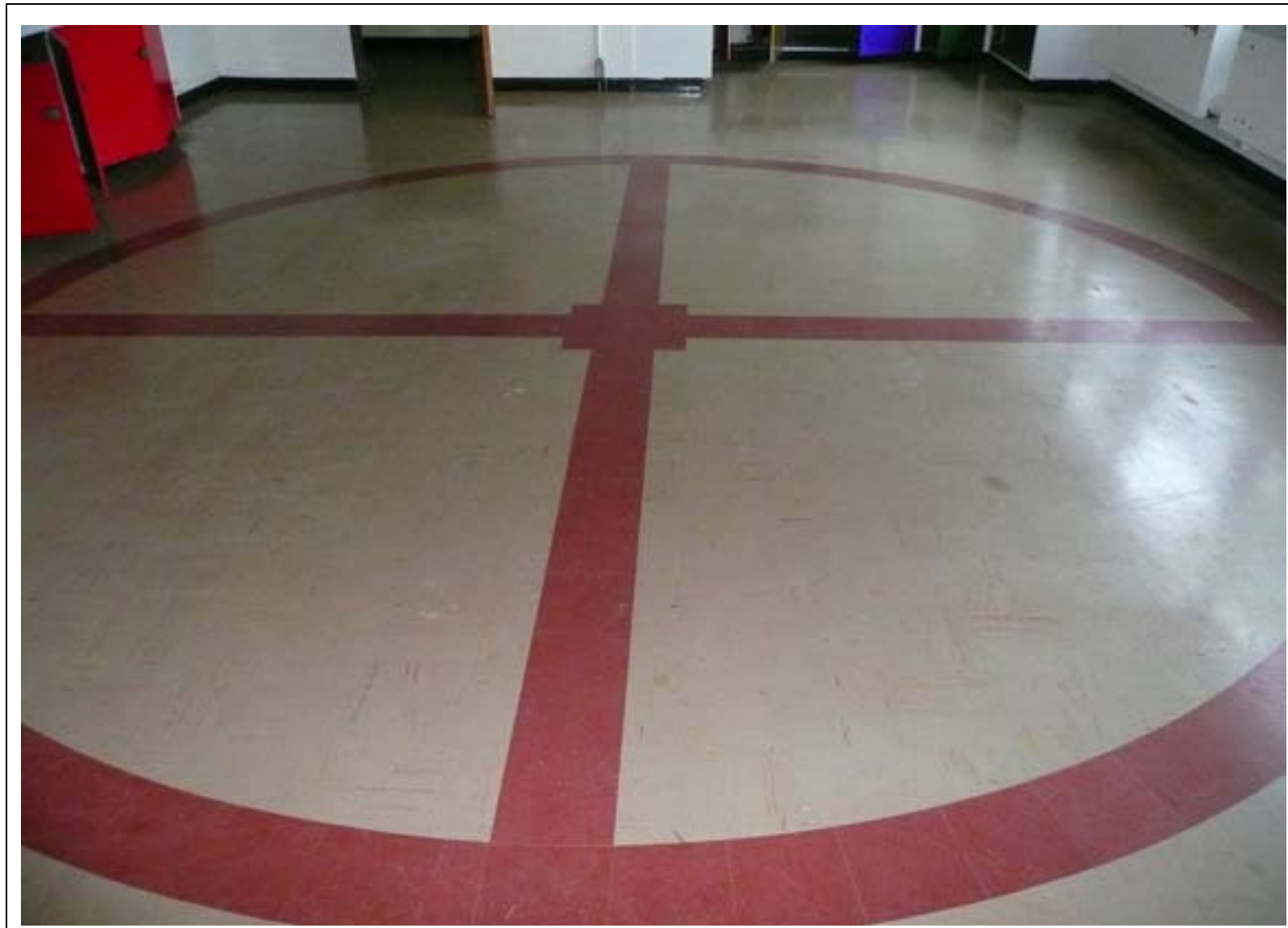

Photo 124. Original four-square designed in the floor tiles in Primary R oom No. 23.

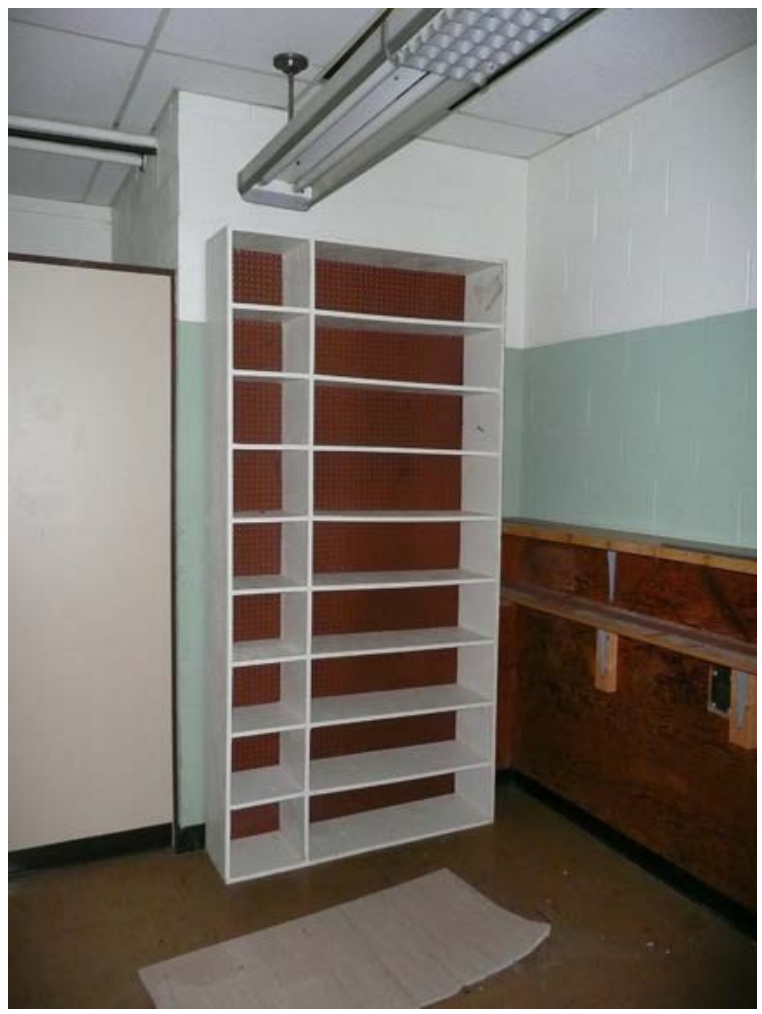

Photo 125. Replacment bookshelf in Priamary R oom No. 23. 


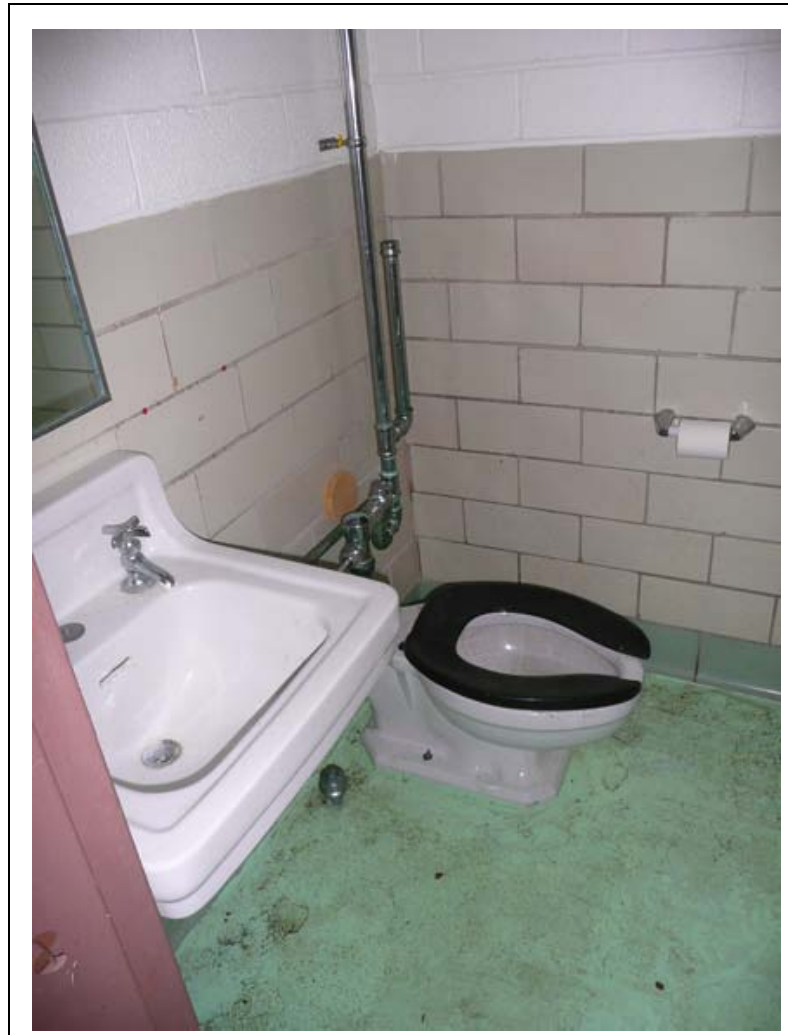

Photo 126. One of two original toilet rooms located in the Primary R oom No. 23.

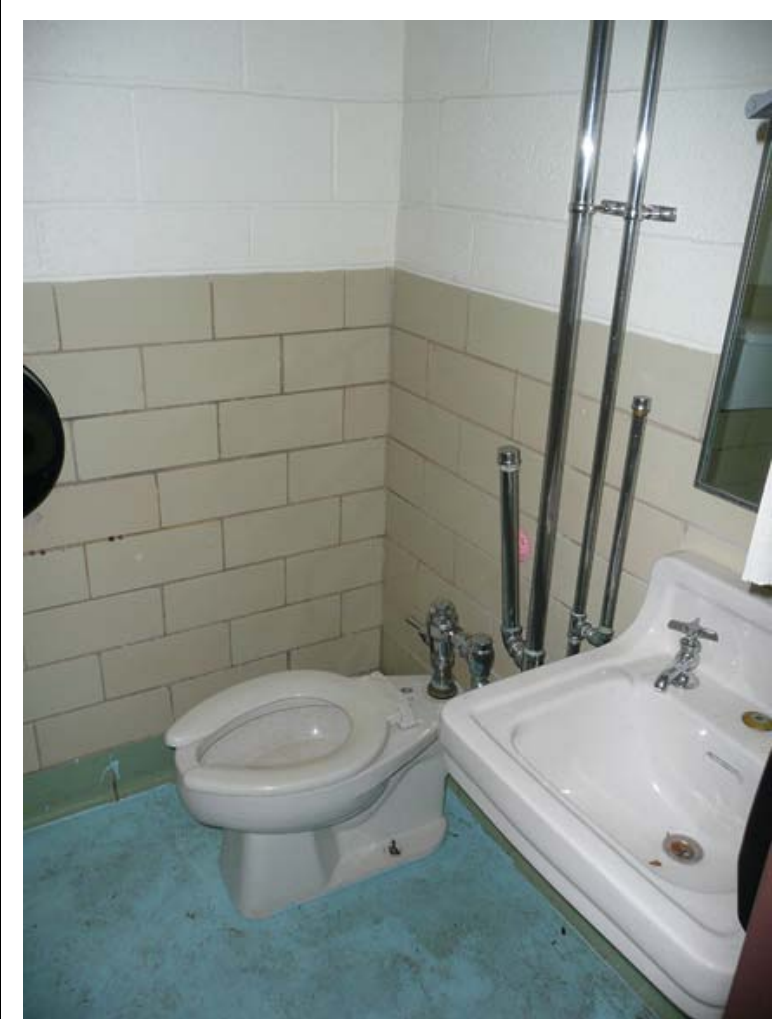

Photo 127. O ne of two original toilet rooms located in the Primary R oom No. 23. 


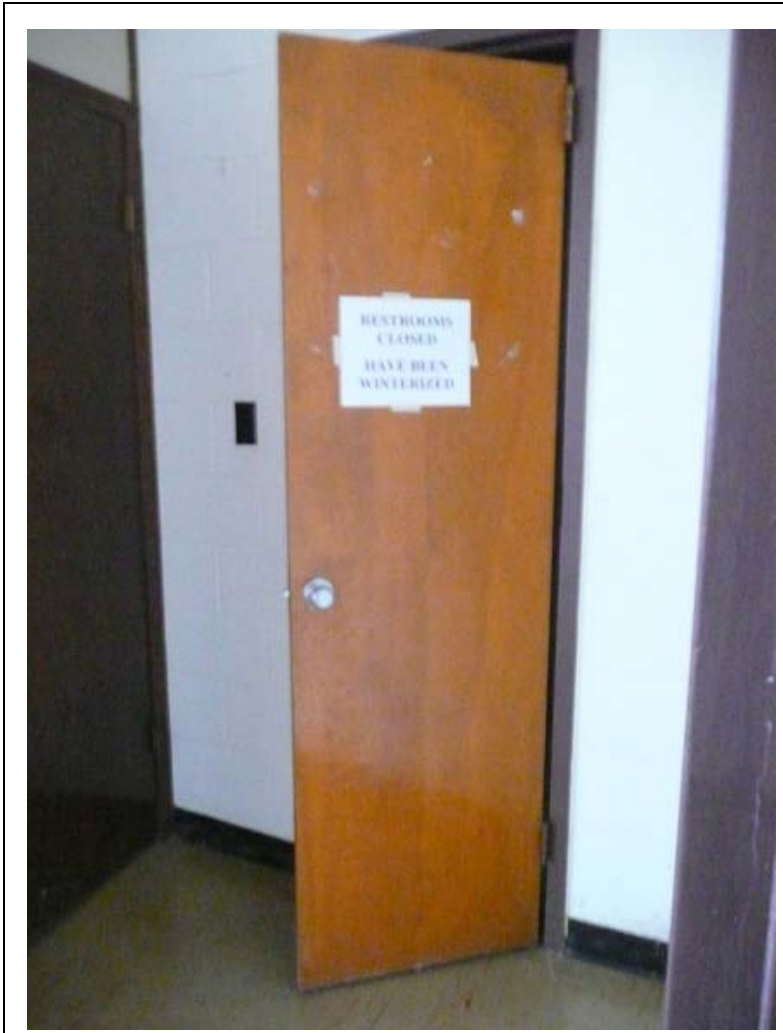

Photo 128. Original solid wood closet door located in the Primary R oom No. 23.

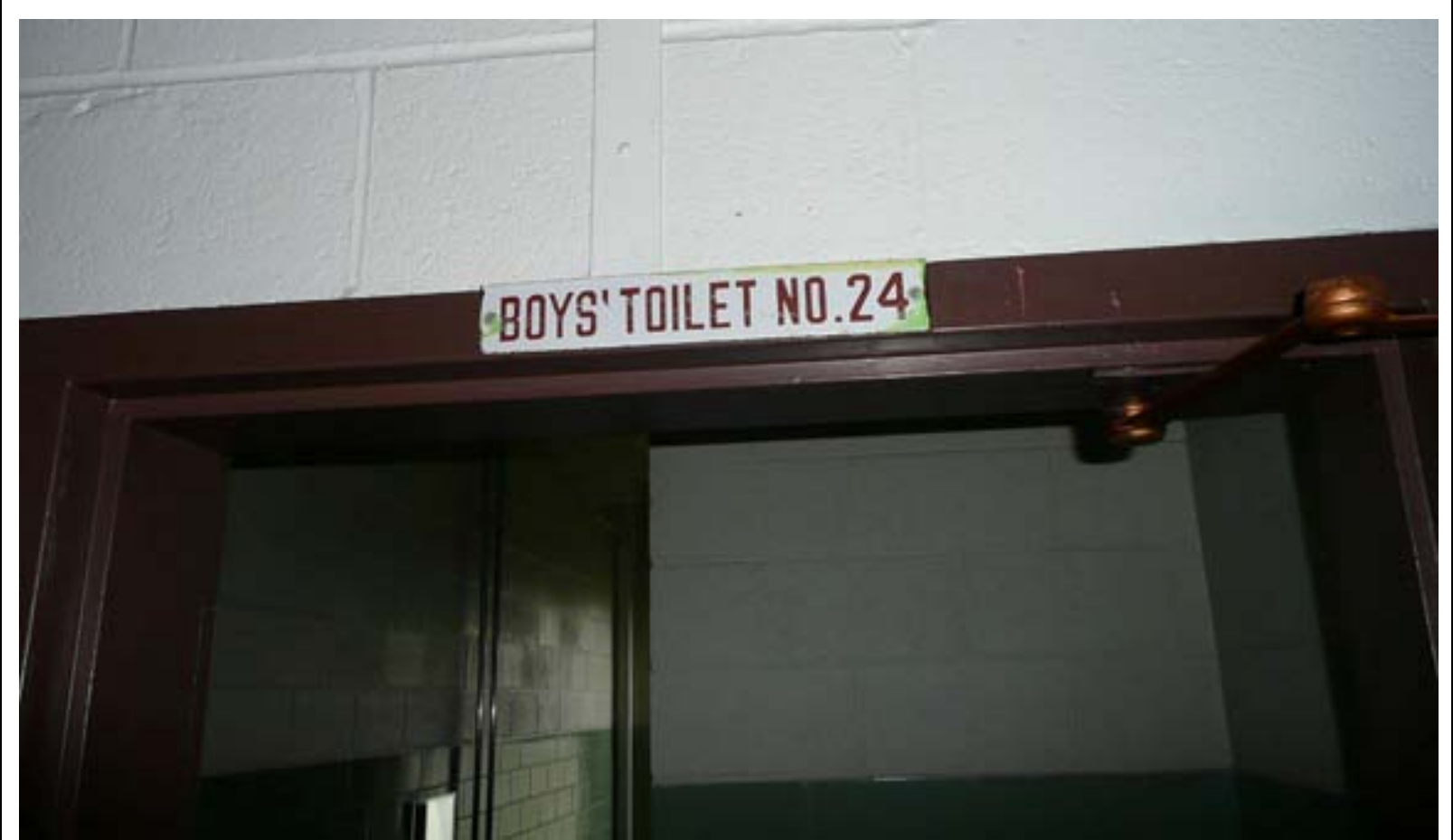

Photo 129. Original Boys' T oilet No. 24 sign. 


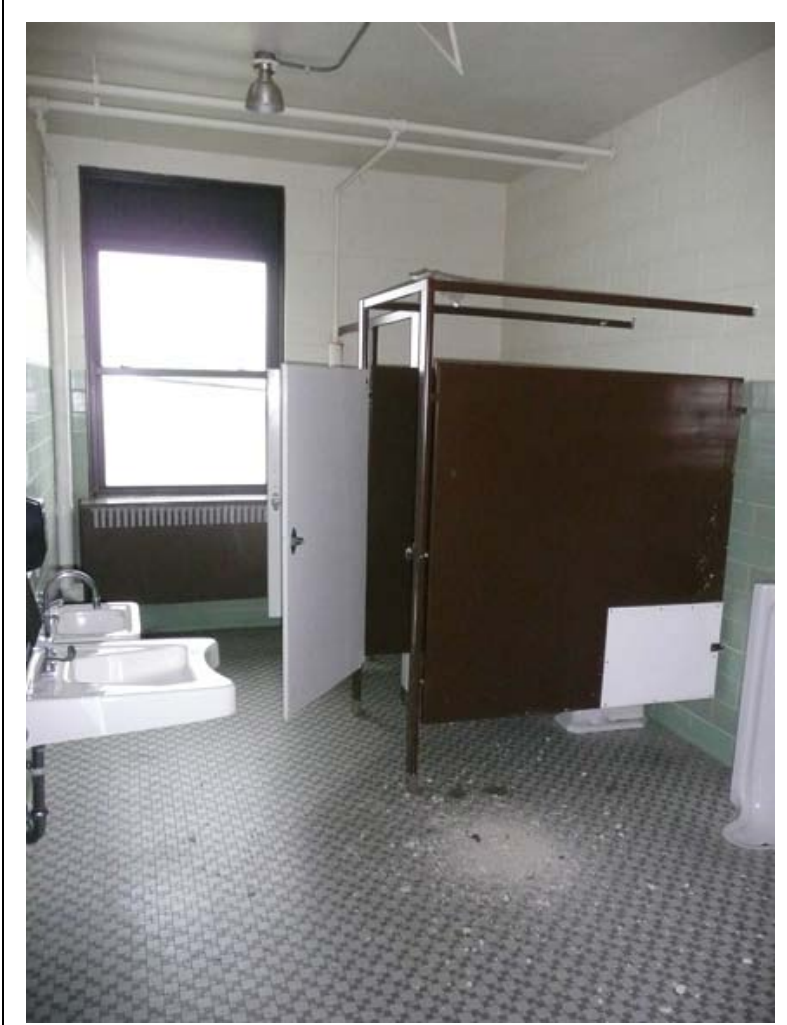

Photo 130. Original mosaic tile floor and glazed tile walls in B oys' T oilet No. 24.

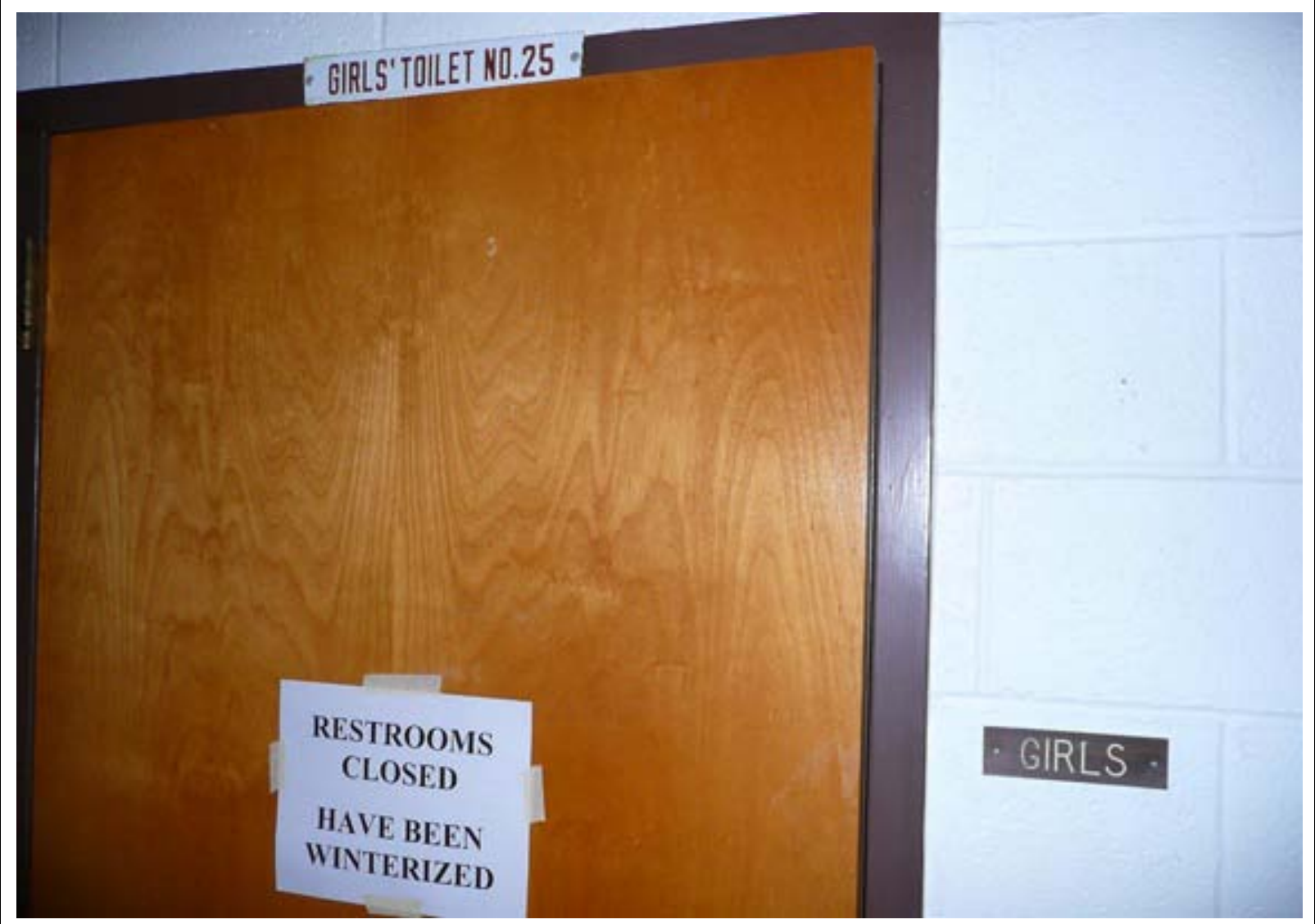

Photo 131. Original G irls' Toilet No. 25 sign and replacement door. 


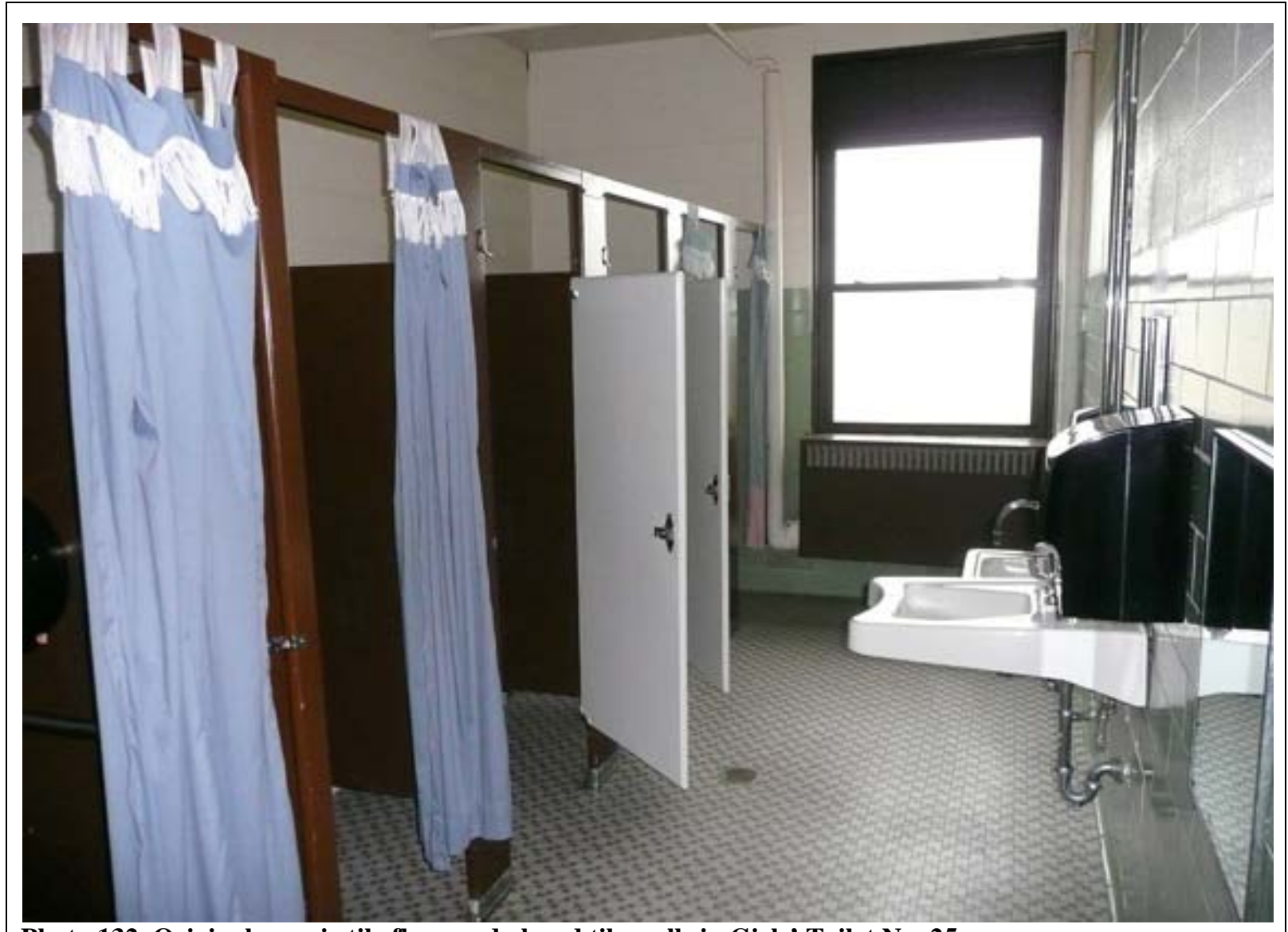

Photo 132. Original mosaic tile floor and glazed tile walls in G irls' Toilet No. 25.

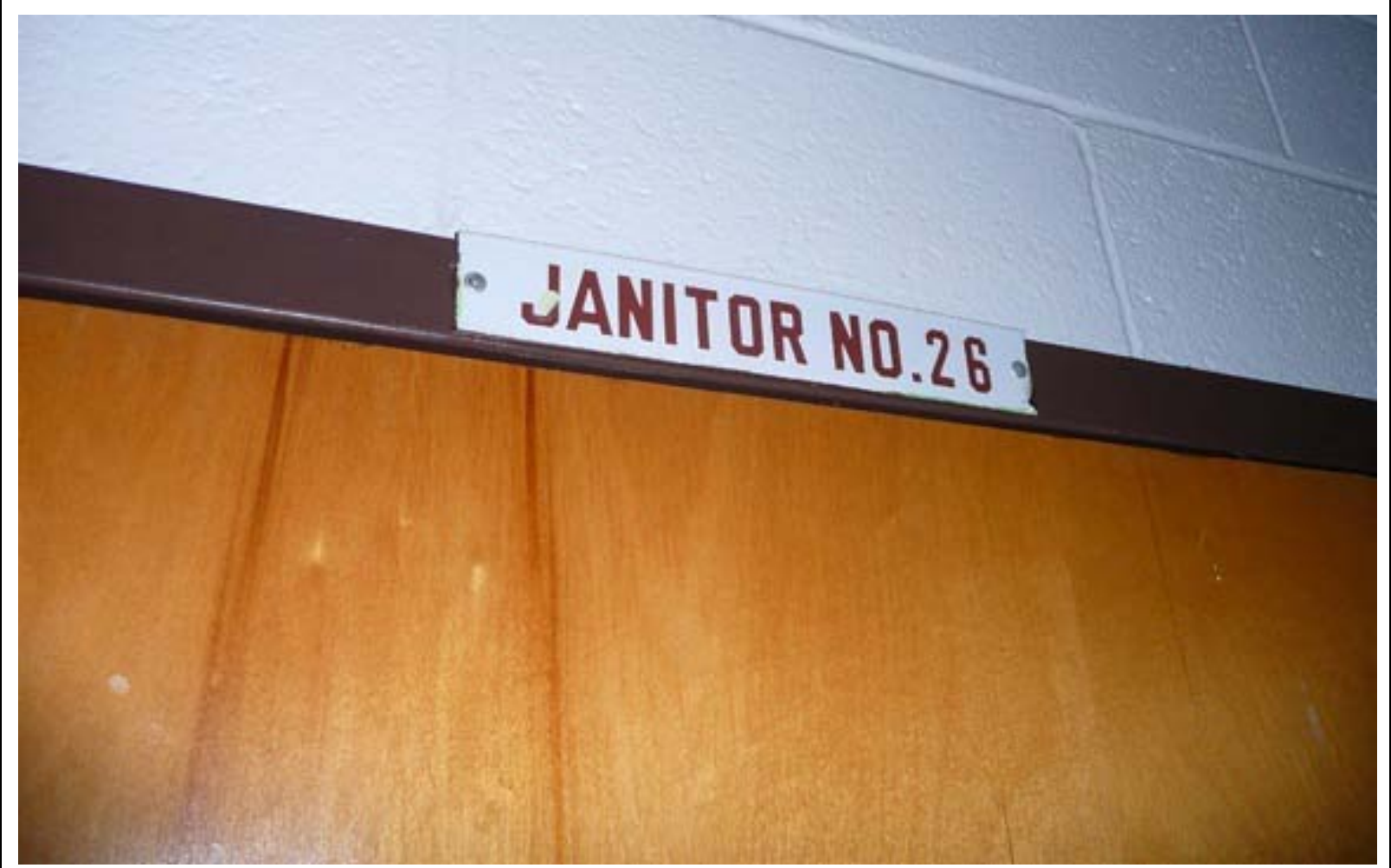




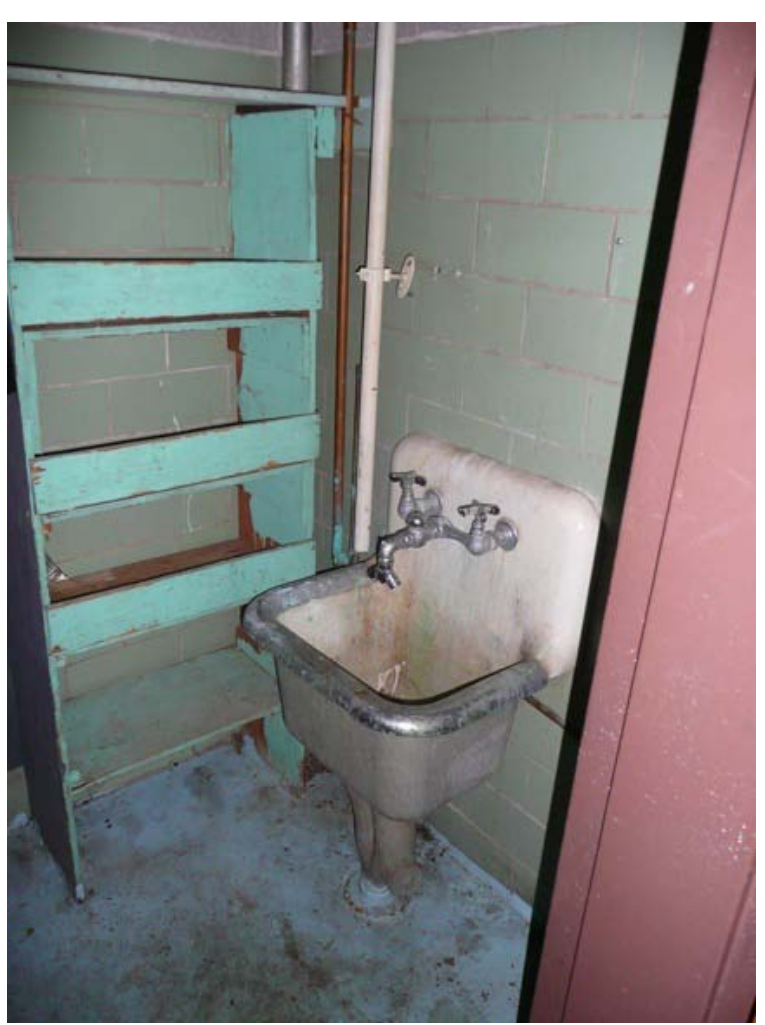

Photo 134. Original glazed tile walls and mop sink in J anitor No. 26. 


\begin{tabular}{|l|l|}
\hline \multicolumn{1}{|l|}{ MAPS } & \\
\hline COORDINATES & USG S QUAD \\
\hline UTM 15 & Waynesville \\
4181988N & \\
\hline $575278 \mathrm{E}$ & \\
\hline
\end{tabular}

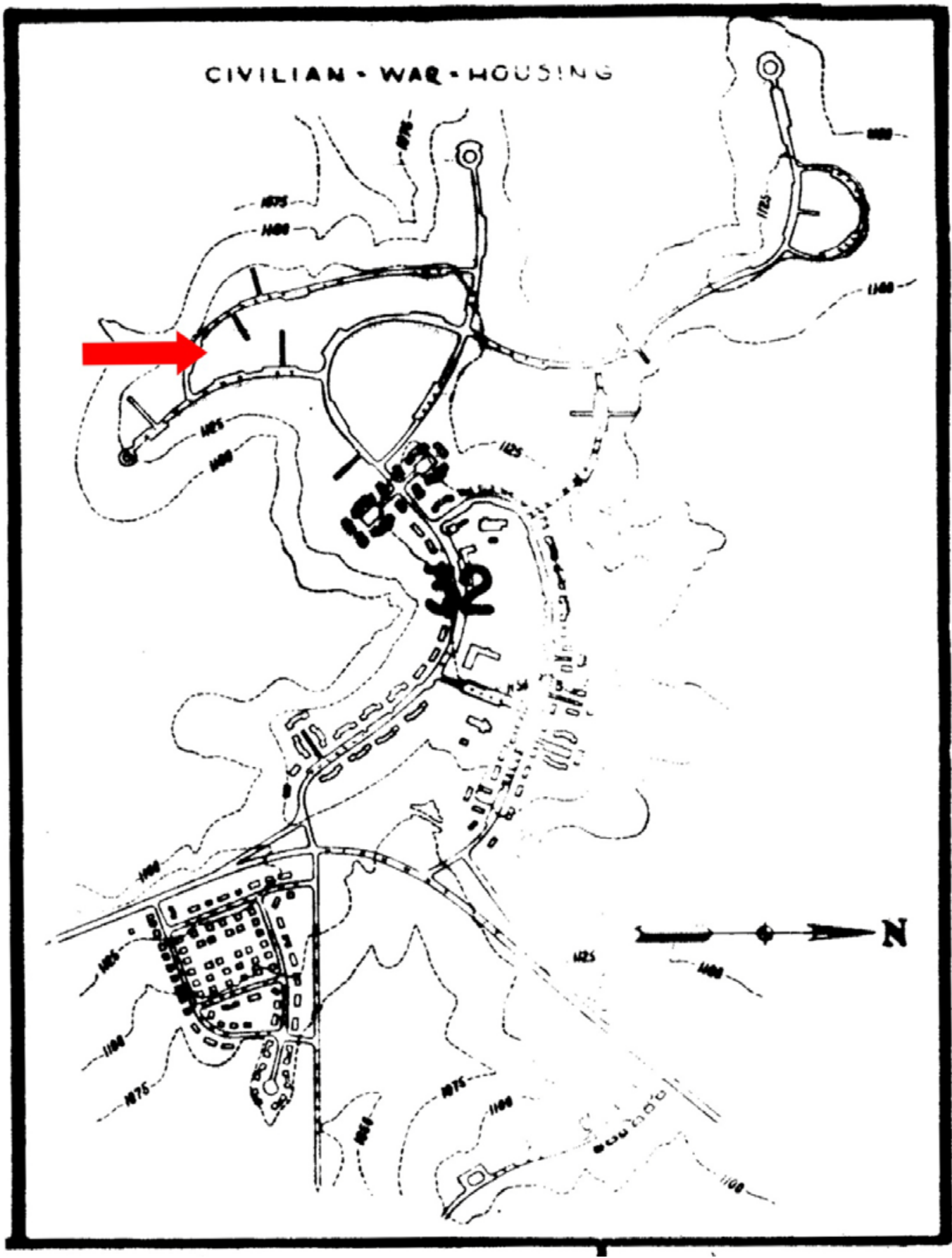

M ap 1. Future location of Building 6824 indicated by red arrow, on portion of the 1946 cantonment map. 


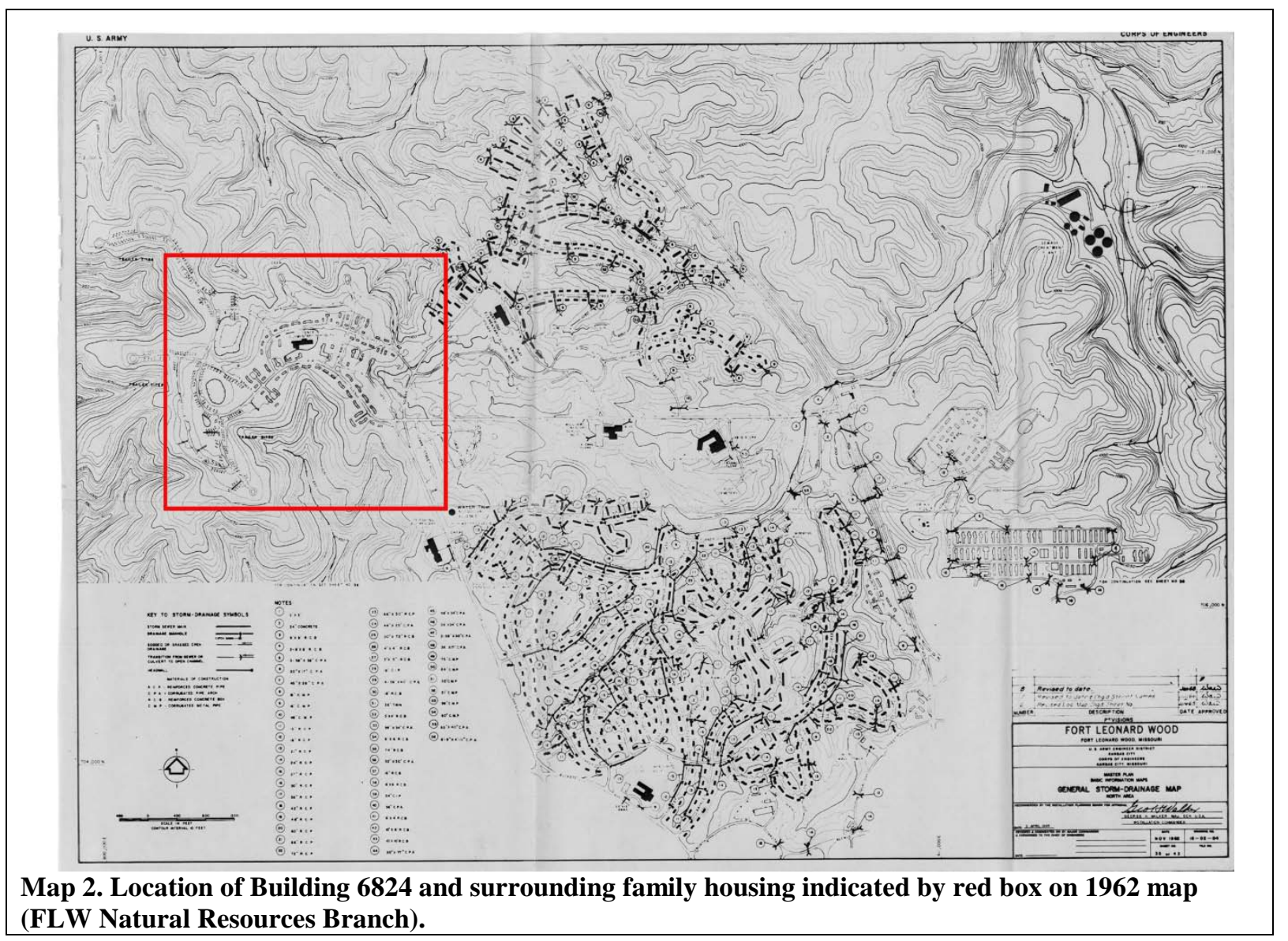




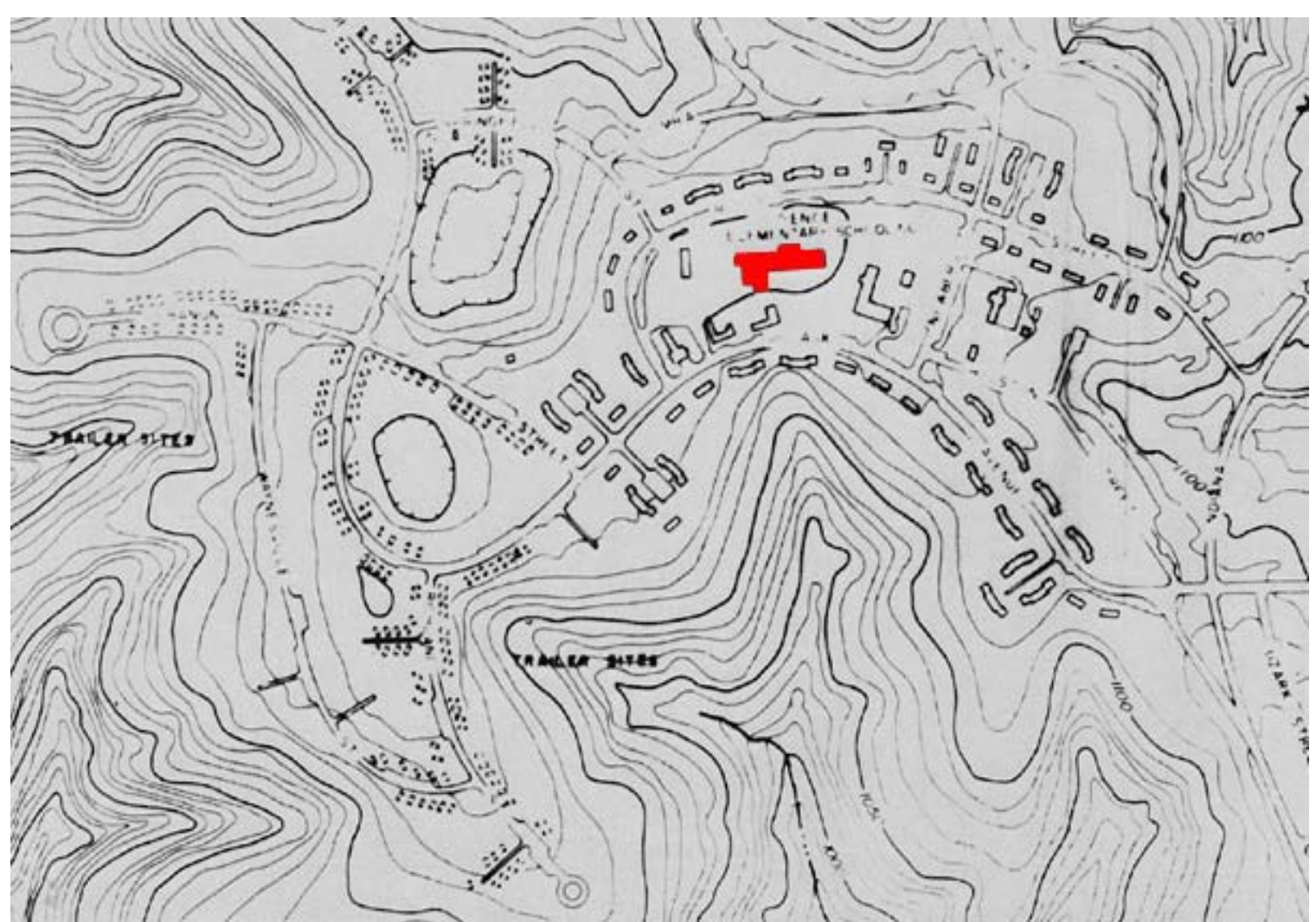

M ap 3. Close-up of 1962 map (above) with Building 6824 highlighted in red ( FL W Natural Resources Branch).

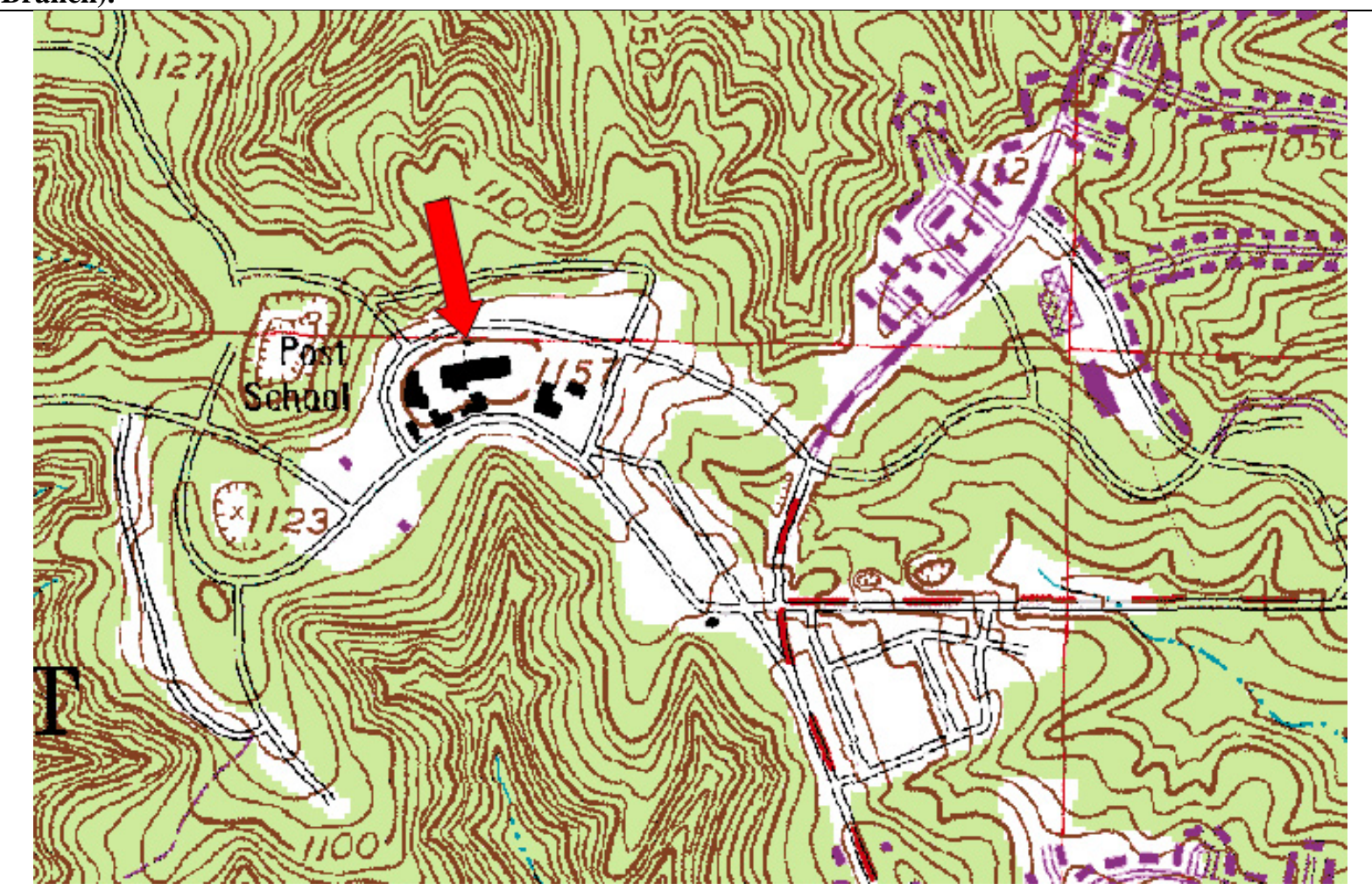

M ap 4. A 1997 map with Building 6824 highlighted with red arrow (US G eological Service). 


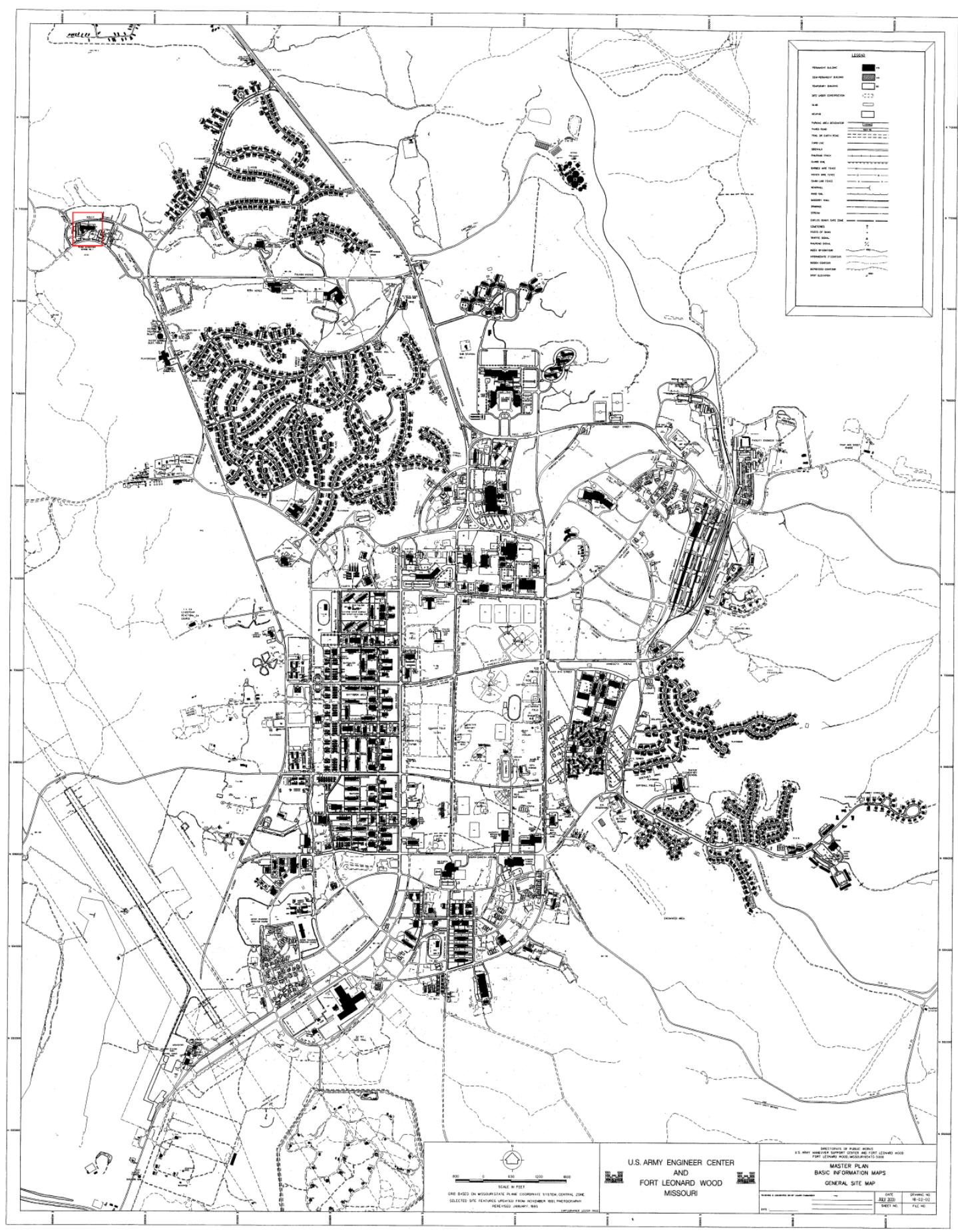

M ap 5. FL W, with Building 6824 indicated by the red box, J uly 2000 (FL W Natural Resources Branch). 


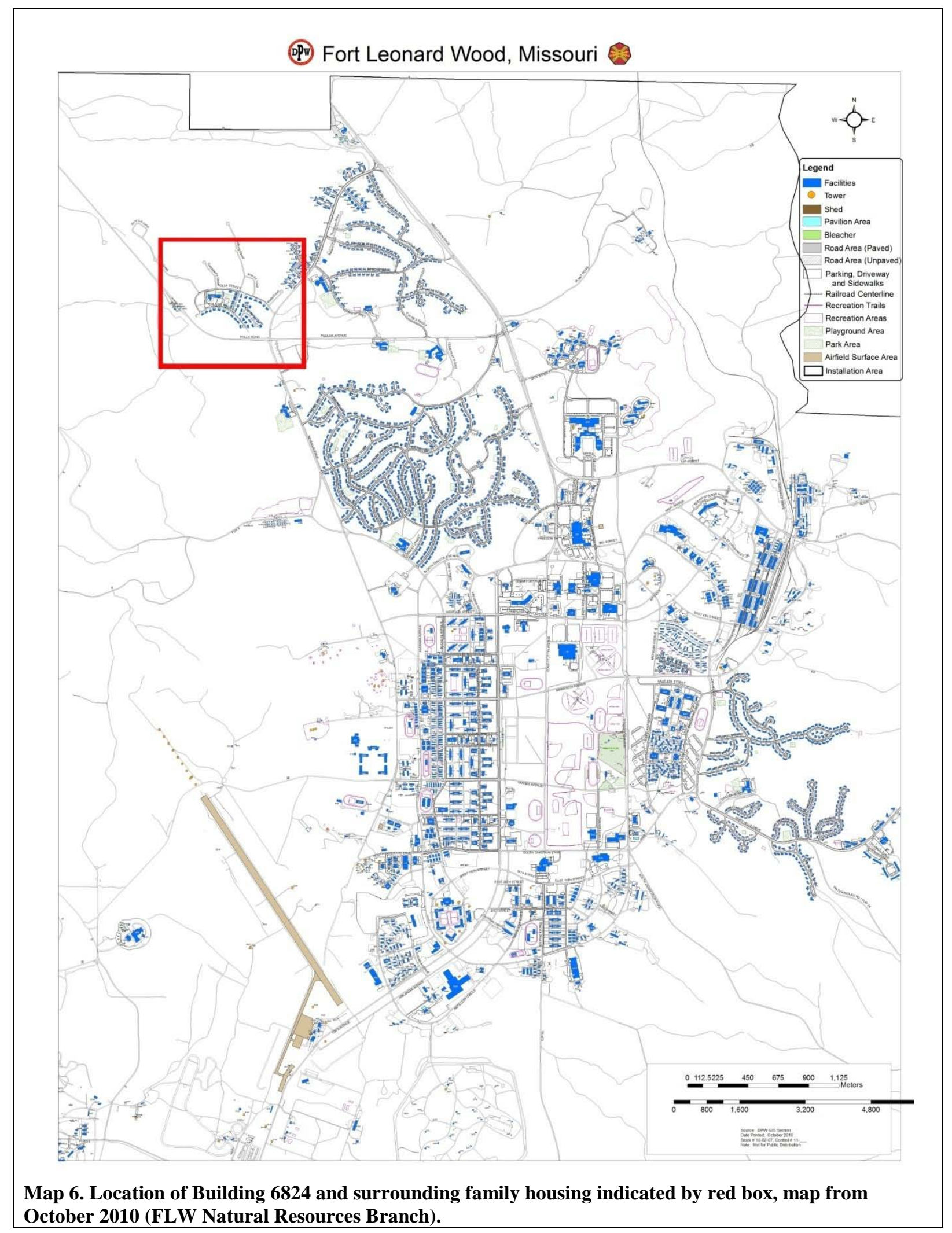




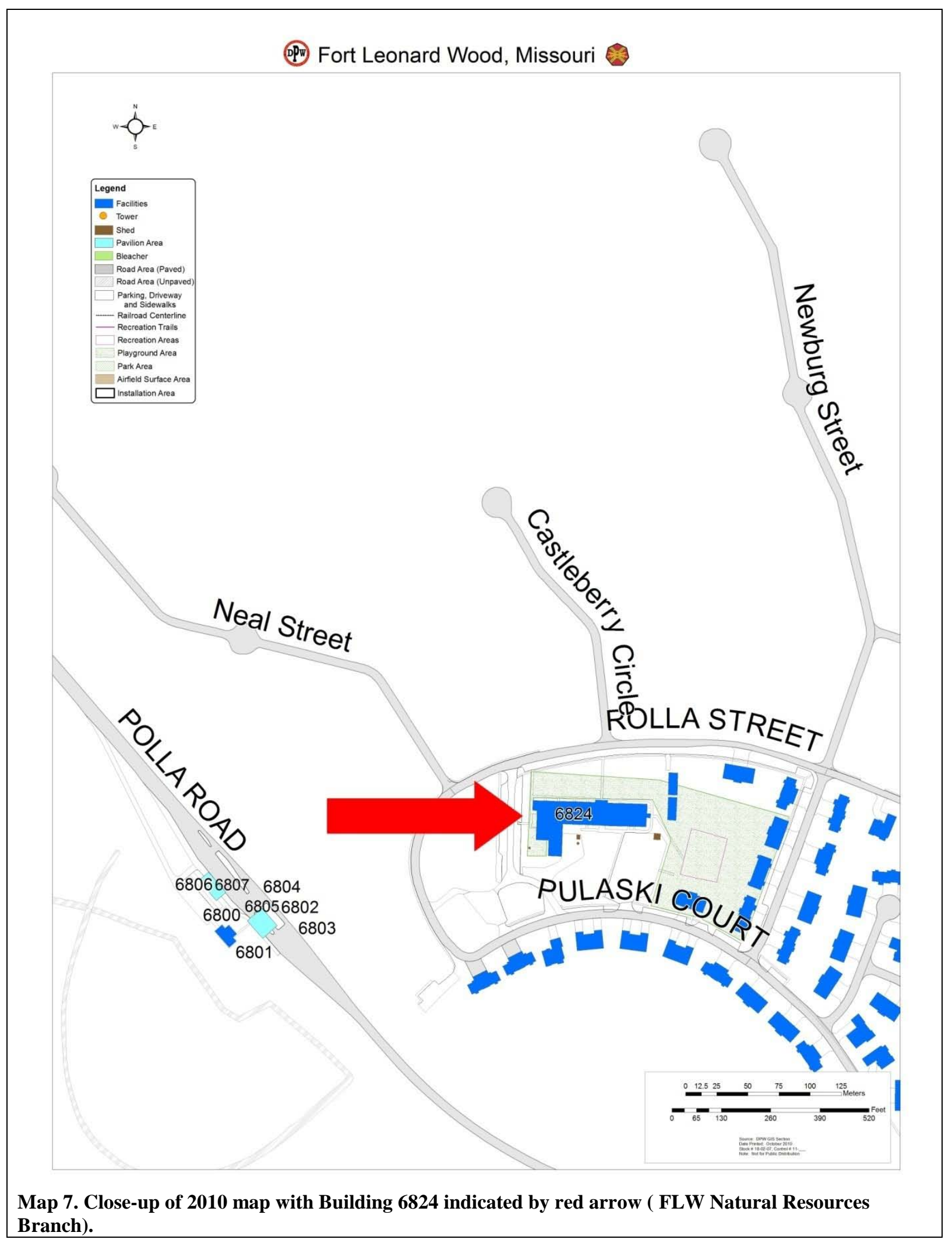




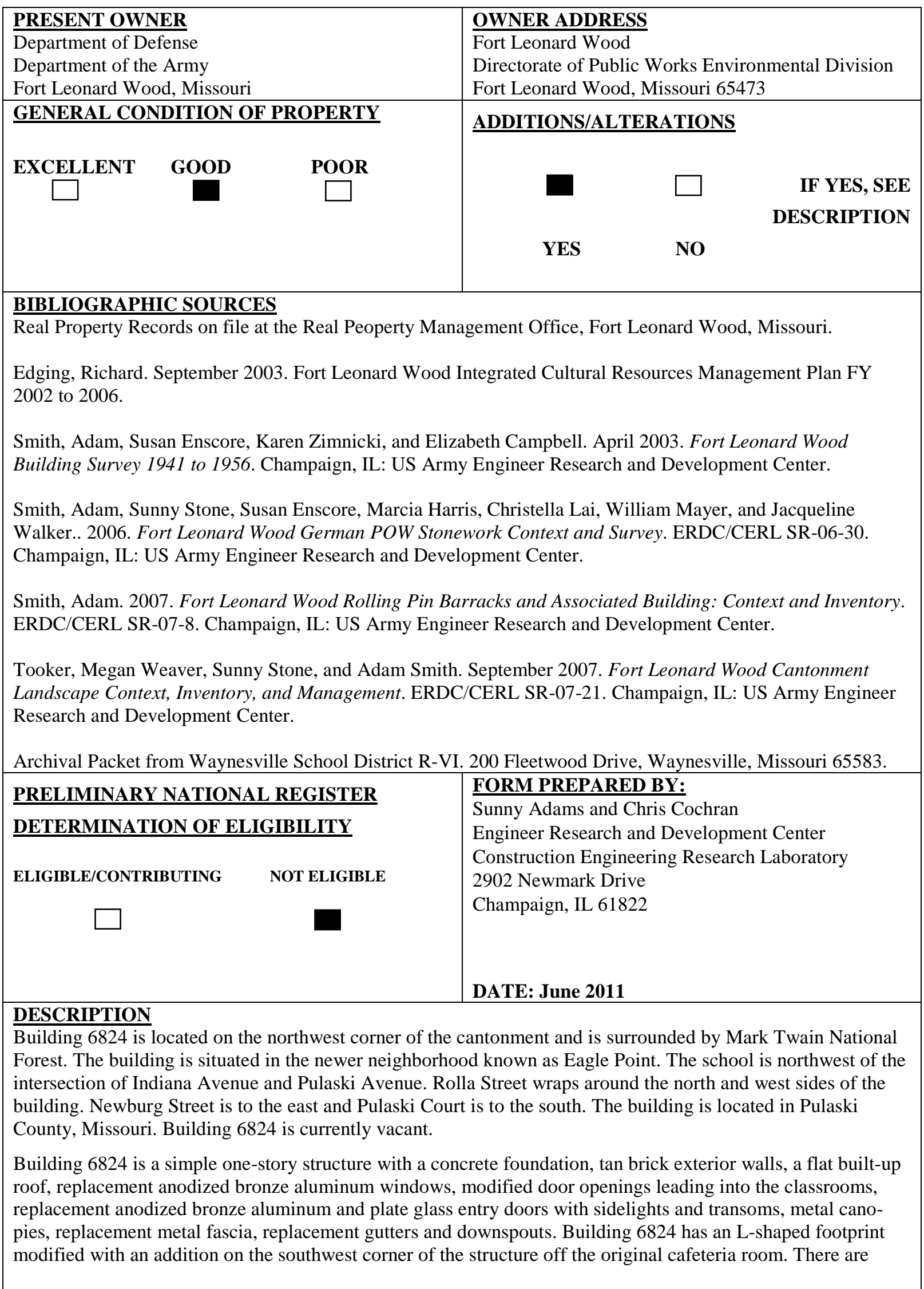


three separate playground areas around the building. The structure has an approximate area of 20,864 square feet. The building is currently vacant.

The exterior of the building has been modified over the years and the major al teration is the window pattern with the replacement of the original windows with the current windows, along with the modification of newer door openings being cut and fitted into the brick walls and then filled with single metal entry doors and metal siding.

The interior of the building has twelve classroom spaces, an office/health room area, four toilet rooms, a teacher's room, a kitchen, and a cafeteria. The interior consists of original vestibule doors with sidelights and transoms, asbestos tiled corridor floors and some classroom floors, replacement acoustical tile drop ceilings, both original pendent ceiling light fixtures and replacement light fixtures, replacement wood classroom doors (with the exception of one door), toilet room fixtures, and classroom fixtures such as a workstation, coat "cubby" area, tackboards, chalkboards, and bookshelves.

North E levation: The north elevation faces Rolla Street. The main entry into the building is located in the middle of the elevation and is defined by a recessed entry (photo 1 ). The entry is replacement double doors; anodized bronze aluminum and plate glass with sidelights and two fixed transoms above. A single replacement anodized bronze aluminum one-over-one window flanks either side of the entry (photo 5). A metal canopy stretches above the entry and these two windows. The rest of the elevation is defined by a wall of replacement anodized bronze aluminum one-over-one windows. The left side of the elevation has fifteen windows and one single entry door (photo 2). J ust to the right of the door is a set of paired replacement windows. The right side of the north elevation is dominated by a wall of replacement windows. Three new single door openings have been cut into the brick wall. All three of the openings have a metal door. T wo of the three openings also have metal siding around the door, while the third one has plywood filled in around the door (photo 6). There are two separate fence- enclosed playgrounds on the north side of the building (photos 34-35).

West Elevation: The left side of the west el evation projects outward from the rest of the exterior wall. To the right of this portion of the exterior wall is a recessed double door entry. The doors are replacement anodized bronze and plate glass with one fixed transom above (photo 9). A lso near this entry is a metal "footscraper" (photo 10). To the right of the entry doors are two single replacement windows. The middle portion of the west elevation has a wall of six replacement windows and a single replacement door (photo 11). This door was original to the construction drawings, not a later addition. The far right side of the west el evation is recessed from the rest of the exterior wall. This portion of the el evation is a later addition that was added to the original cafeteria (photo 13). There is a single entry anodized bronze aluminum and plate glass door leading into the addition. The addition is constructed of similar type tan brick and has a flat roof. A fenced playground is located on the southwest corner of the building (photo 36).

South E levation: The far left side of the south elevation is recessed from the portion where the newer addition projects outward (photo 14). A recessed double door entry is located on the far left side of the exterior wall. The entry consists of anodized bronze aluminum and plate glass double doors with two sidelights and a transom above (photo 15). A concrete pad stretches outward from the entry and runs along the west side of the addition. The south exterior wall of the addition has no door or window openings. To the right of the addition, the rest of the exterior wall is recessed. A solid metal door provides access into the boiler room. N ext to this door is a set of paired replacement windows. The majority of the south elevation is dominated by a wall of replacement windows (photo 23). There are two groups of windows with two newer door openings cut into the wall to the left of a recessed main entry and then there are three groups of windows with three newer door openings cut into the exterior wall to the right of the recessed entry (photo 24). The recessed entry is the main entry into the building on the south el evation (photo 25). The entry consists of replacement anodized bronze al uminum and plate glass doors with a fixed transom above. A n original metal "footscraper" is located near the entry.

E ast E levation: The left side of the east el evation is recessed from the right side. The left side consists of the newer addition to the cafeteria and the original cafeteria wall. There are two groups of replacement windows on the east wall of the cafeteria. The left group of windows is on the addition portion, while the right group is on the original portion (photo 18). There is also a single entry replacement anodized bronze aluminum and glass door to the right of the group of windows on the original portion of the wall (photo 21). The right side of the east elevation projects outward and is defined as a main entry into the building from this side of the structure. The entry is recessed and consists of double doors of anodized bronze and glass (photo 28). A flat roof metal canopy supported by two metal columns hangs over a concrete stoop with metal handrails (photos 27-30). On the far 
right side of the east elevation is a newer door opening cut into the exterior wall. The opening is filled with a metal door with a small light (photo 31). A concrete ramp with metal handrail provides access to the door. A playground is located on the northeast corner of the structure (photos 32-33).

Vestibule on the north entry: The vestibule has original three-light wood doors with two fixed pane transoms above, original door hardware, acoustical tile drop-ceiling, asbestos tile floor, and a metal radiator cover (photos 38-40).

Corridors: The classroom corridor stretches east to west through the middle of the building providing access to both classrooms and toilet rooms on either side of the corridor (photos 79 and 96). This corridor terminates at two vestibules; one at each end (photos 47, 118, and 119). A n intersecting corridor is located near the middle that leads out to two original vestibules and the entries on the north and south el evations (photos 41 and 43). A nother corridor is located at the southwest end of the structure that provides access to the Cafeteria Room No. 22 and Primary Room No. 23 (photo 119). The corridors have acoustical tile drop-ceilings, concrete block walls, and asbestos tile floors (photo 44). There are several push-pin cork boards framed on the concrete block walls of the corridors, along with a couple of water fountains (photos 80 and 120). A hop-scotch game is depicted in the tile floor near the cafeteria entry doors. This detail was part of the original design of the interior of the school (photos 109 and 121 and floor plan 3); however, it was originally suppose to be located in the corridor between Classroom N 0. 3 and Boiler Room No. 18.

Classroom No. 1: Classroom No. 1 is located at the northwest corner of the building. The room has a small area of floor tiles near the workstation and sink but the rest of the floor is covered with carpet, concrete block walls, an acoustical tile drop-ceiling, replacement ceiling light fixtures, an original open coat "cubby" area, a small original storage closet with an original wood door and hardware, an original bookshelf, and original wood frames for the tack board and chalkboard (photo 46). A newer radiator system stretches below the replacement windows on the north wall. A new door opening has been cut into the dividing wall between Classroom N 0.1 and Classroom No. 2 on the east wall. A metal door fills the opening. A ccording to the original floor plans, Classroom N 0.1 was originally used as the M usic, A rts and Crafts room.

Classroom No. 2: Classroom N 0. 2 is located at the north side of the building near the west end of the structure, between Classrooms N 0.1 and 3. The room has as workstation and sink area, a carpeted floor, concrete block walls, an acoustical tile drop-ceiling, replacement ceiling light fixtures, an original open coat "cubby" area, a small original storage closet with an original wood door and hardware, an original bookshelf, and original wood frames for the tack board and chalkboard (photo 49). A newer radiator system stretches below the replacement windows on the north wall. A newer door opening has been cut into the dividing wall between Classroom N 0.1 and Classroom N 0. 2 on the west wall within the coat "cubby" area. A metal door fills the opening.

Classroom No. 3: Classroom No. 3 is located at the north side of the building, between Classrooms N 0. 2 and 4. The room has as workstation and sink area, a carpeted floor, concrete block walls, an acoustical tile dropceiling, original pendent ceiling light fixtures, an original open coat "cubby" area, a small original storage closet with an original wood door and hardware, an original bookshelf, and original wood frames for the tack board and chal kboard (photo 51). A newer radiator system stretches below the replacement windows on the north wall. A new door opening has been cut into the dividing wall between Classroom N o. 3 and Classroom No. 4 on the east wall.

Classroom No. 4: Classroom No. 4 is located at the north side of the building, between Classroom No. 3 and Health Room N o. 5. The room has as workstation and sink area, a carpeted floor, concrete block walls, an acoustical tile drop-ceiling, replacement ceiling light fixtures, an original open coat "cubby" area, a small original storage closet with an original wood door and hardware, an original bookshelf, and original wood frames for the tack board and chalkboard (photo 53). A newer radiator system stretches below the replacement windows on the north wall. A new door opening has been cut into the dividing wall between Classroom N o. 3 and Classroom N 0.4 on the west wall within the coat "cubby" area. A metal door fills the opening.

Health R oom No. 5: The only original interior door leading from the corridors into the rooms located off of them is located at Health Room N o. 5. The door is solid wood with two small lights located near the top of the door (photo 54). The room has concrete block walls, drywall frame walls, a carpeted floor, acoustical tile dropceiling, and original drop ceiling light fixtures (photo55). There is a row of replacement base cabinets with countertops located on the west wall (photo 59). There is small toilet room with original glazed tile walls and an original wood door (photo 56). Located adjacent to the toilet room is a small open space with glazed tile walls, a 
sink, and a newer door leading to Classroom No. 4 (photo 58). According to the original plans there was a dividing wall between Health Room No. 5 and Office N o. 6; however, this wall has since been removed, making this one large room.

Office No. 6: The room is located near the main entry and vestibule on the north elevation. The office has concrete block walls, carpeted floors, acoustical tile drop-ceiling, and replacement pendent light fixtures (photo 61). A newer window opening has been cut into the east wall of the office in order to provide visual access to the main entry on the north corridor/vestibule area (photo 42). A ccording to the original plans, there was a dividing wall between Health Room N 0. 5 and Office N 0. 6; however, this wall has since been removed, making this one large room.

Boys' Toilet No. 7: The room is located adjacent to the main entry on the north elevation and is next to J anitor Room N o. 9. The toilet room consists of the original mosaic tile floor, original glazed tile walls, and an original light fixture. There is a single replacement window located on the north wall (photo 62-64).

Girls' Toilet No. 8: The room is located between J anitor Room No. 9 and Teacher W ork Room No. 10 on the north side of the building. The toilet room consists of the original mosaic tile floor, original glazed tile walls, and an original light fixture. There is a single replacement window located on the north wall (photo 67-69).

J anitor R oom No. 9: The room is located between B oys' Toilet No. 7 and Girls' Toilet No. 8 on the north side of the building near the main entry. The room is small and consists of the original glazed tile walls, concrete floor, and an original mop sink (photo 66).

Teachers' Work Room No. 10: The room is located between Girls' Toilet N 0.8 and Classroom No. 11 on the north side of the building. The room has concrete block walls, carpeted floors, acoustical tile drop-ceiling, and original pendent light fixtures (photo 70).

Classroom No. 11: The room is located at the north side of the building, between Teachers W ork Room N o. 10 and Classroom N 0.12 . The room has a workstation and sink area, a partially carpeted and partially tiled floor, concrete block walls, an acoustical tile drop-ceiling, original ceiling pendent light fixtures, an original open coat "cubby" area, a small original storage closet with an original wood door and hardware, an original bookshelf, and original wood frames for the tack board and chalkboard (photos 71-74). A newer radiator system stretches below the replacement windows on the north wall.

Classroom No. 12: The room is located at the northeast corner of the building, next to Classroom No. 11. The room has a workstation and sink area, asbestos tile flooring, concrete block walls, an acoustical tile drop-ceiling, original ceiling pendent light fixtures, a small original storage closet with an original wood door and hardware, an original bookshelf, and original wood frames for the tack board and chalkboard (photos 76-77). A newer radiator system stretches below the replacement windows on the north wall. The southwest corner of the room has been modified with the construction of partition walls to create a small enclosed area in that part of the room. Also, a newer door opening has been cut into the east wall of the room leading to the outside of the building. A metal door with a large light fills the opening (photo 77).

Classroom No. 13: Classroom No. 13 is located at the southeast corner of the building, next to Classroom No. 14. The room has as workstation and sink area, a partially carpeted and partially tiled floor, concrete block walls, an acoustical tile drop-ceiling, original pendent ceiling light fixtures, an original open coat "cubby" area, a small original storage closet with an original wood door and hardware, an original bookshelf, and original wood frames for the tack board and chal kboard (photo 82). A newer radiator system stretches below the replacement windows on the south wall.

Classroom No. 14: The room is located near the southeast corner of the building, between Classrooms N o. 13 and 15. The room has a workstation and sink area, a partially carpeted and partially tiled floor, concrete block walls, an acoustical tile drop-ceiling, original pendent ceiling light fixtures, an original open coat "cubby" area, a small original storage closet with an original wood door and hardware, an original bookshelf, and original wood frames for the tack board and chalkboard (photos 86-87). A newer radiator system stretches bel ow the replacement windows on the south wall.

Classroom No. 15: The room is located at the south side of the building and is between Classrooms No. 14 and 16. The room has a workstation and sink area, a partially carpeted and partially tiled floor, concrete block walls, an acoustical tile drop-ceiling, original pendent ceiling light fixtures, an original open coat "cubby" area that has been slightly modified with newer shelves, a small original storage closet with an original wood door and hard- 
ware, and original wood frames for the tack board and chalkboard (photo 92). A newer radiator system stretches below the replacement windows on the south wall.

Classroom No. 16: The room is located on the south side of the building, between Classrooms No. 15 and 17. The room has a workstation and sink area, a partially carpeted and partially tiled floor, concrete block walls, an acoustical tile drop-ceiling, original pendent ceiling light fixtures, an original open coat "cubby" area, a small original storage closet with an original wood door and hardware, an original bookshelf, and original wood frames for the tack board and chalkboard (photo 94). A newer radiator system stretches below the replacement windows on the south wall. A newer door opening has been cut into the west wall of the classroom that leads to Classroom N 0. 17. A metal door with a small light fills the opening (photo 95).

Classroom No. 17: The room is located on the south side of the building, between Classroom No. 16 and B oiler Room N o. 18. The room has a workstation and sink area, a partially carpeted and partially tiled floor, concrete block walls, an acoustical tile drop-ceiling, original pendent ceiling light fixtures, an original open coat "cubby" area, a small original storage closet with an original wood door and hardware, an original bookshelf, and original wood frames for the tack board and chalkboard (photos 98-99). A newer radiator system stretches below the replacement windows on the south wall.

Boiler R oom No. 18: This room is located between to Classroom No. 17 and K itchen No. 21. The original sliding track door leading from the corridor into the room is intact. The room has a concrete floor and concrete block walls. The room is filled with mechanical equipment and piping. A set of paired replacement windows and a single replacement entry door is located on the south wall of the room. A newer metal door leads from the corridor into the kitchen/storage area.

Storage Area No. 20: This room is located on the northwest side of the kitchen space. The room is enclosed and contains lots of wood shelving units (photo 104).

K itchen No. 21: The kitchen is located north of the cafeteria space. The kitchen has concrete block walls, a red clay tile floor, and an acoustical tile drop ceiling. There is a small area with a stainless steel sink and countertop that was used for washing the trays/dishes. A small "pass-through" window is located near the sink (photo 105). All of the cooking and prepping equipment has been removed, except for the stainless steel range hood (photos 107-108).

C afeteria No. 22: This is a large open room with a concrete floor, concrete block walls, an acoustical tile drop ceiling, original pendent ceiling light fixtures, and original ceiling mounted radiators (photos 110-111). A wall of replacement windows and one replacement door are located on the east side of the room. A set of double wood replacement doors provides access into the cafeteria from the corridor on the west wall. The original size of the cafeteria was enlarged at an unknown date. The addition was constructed on the south side of the original space (photo 113) and is accessed through two single door openings that were cut into the original south exterior wall of the building (photo 111).

Primary Room No. 23: This room is located on the southwest corner of the building. It is across the corridor from the cafeteria and south of B oys' Toilet N 0 . 24. The room is larger than the other classrooms found in the building. The tile floor is covered with a four-square game laid out in the tile design (photos 122-124). A ccording to the original drawings, this was part of the original design (see drawing 4). The room has a workstation and sink area, concrete block walls, an acoustical tile drop-ceiling, original pendent ceiling light fixtures, an original storage closet with an original wood door and hardware, an original bookshelf, and original wood frames for the tack board and chalkboard (photos 122 and 123). A newer radiator system stretches below the replacement windows on the west wall. There are two small toilet rooms located on the north end of the room with original fixtures and glazed tiled walls (photos 126-127).

Boys' Toilet No. 24: The room is located near the southwest corner of the building and is between Primary Room N o. 23 and J anitor Room No. 26. The toilet room consists of the original mosaic tile floor, original glazed tile walls, and an original light fixture. There is a single replacement window located on the north wall (photo 130).

Girls' Toilet No. 25: The room is located on the west side of the building north of J anitor Room N 0. 26 and adjacent to the vestibule located at the west end of the corridor. The toilet room consists of the original mosaic tile floor, original glazed tile walls, and an original light fixture. There is a single replacement window located on the north wall (photo 132). 
J anitor R oom No. 26: The room is located between B oys' Toilet N 0. 24 and Girls' Toilet N o. 25 on the west side of the building near the cafeteria. The room is small and consists of original glazed tile walls, a concrete floor, and an original mop sink (photo 134).

\section{HISTORY}

Building 6824, Pence Elementary School, is 20,864 square feet and was built in 1954 by the Waynesville R-V I School District. The school was designed by Dan R. Sandford and Sons A rchitects of Springfield and K ansas City, M issouri.

The legal description of the building states: The area allocated for construction of an elementary school at Fort L eonard W ood, M issouri, consists of a tract of land lying in the housing area bounded as follows: South and East of Rolla Street, N orth of Pulaski Street, and W est of N ewburg Street. M ore particularly bounded as follows: South of Rolla Street, East of the Commissary, Building \#52, North of the Post Exchange, Building \#25, W est of the Tennis Courts (see A ppendix A).

The Secretary of the A rmy, acting for and on behalf of the U nited States of A merica, as Secretary, did grant L ease N o. DA CA 41-1-99-501 to the W aynesville R-VI School District, for the construction, operation, and maintenance of the school facilities (Pence Elementary School).

The following information was gleaned from a packet given to the ERDC-CERL research team. The packet's information pertained to the ownership of Pence School over the years.

- Department of Health, Education, and Welfare Termination of Permit

The permit granted by the Commissioner of Education, Department of Health, Education, and W elfare, hereinafter called the Commissioner, on N ovember 20, 1956, to the W aynesville Reorganized School District N o. 6, Waynesville, M issouri, hereinafter called the A gency, to use and occupy for school purposes the school facilities designated as Project N o. M 0-56-C-FED-1A 6, on Fort L eonard W ood M ilitary Reservation, $M$ issouri, provides that "This permit shall remain in effect until terminated by mutual agreement of the parties or revoked by the Commissioner." The Commissioner declares permit terminated as of A ugust 29, 1957 (see A ppendix B).

- Permit for School Purposes on F ort Leonard Wood Military Reservation Waynesville, Missouri

The W aynesville Reorganized School District N o. 6, W aynesville, M issouri, a local education agency, is herby granted a permit beginning on the 29th day of A ugust, 1957, by the Commissioner of Education, Department of Health, Education, and W elfare to use and occupy for school purposes, pursuant to Public Laws 815 and 874, 81st Congress, as amended and the permit dated A pril 6, 1954, to the Commissioner from the Secretary of the A rmy, all school buildings and other facilities located on the land in the State of M issouri, County of Pulaski, which is describe at the end hereof, together with all equipment, furnishings, and appurtenances installed therein or located thereon on the date of this permit or thereafter provided by the Commissioner, all of which are hereinafter collectively referred to as the Property.

This permit shall remain in effect until terminated by mutual agreement of the parties or revoked by the Commissioner.

A) Termination of the permit for the use of the land granted to the Commissioner by the Secretary of the A rmy under date of A pril 6, 1954 (see A ppendix C).

- Letter dated $22 \mathrm{M}$ ay 1981

Reference is made to USOE permit for use of Real Property by a Federal A gency Permit N 0. M 0-52C-FED-1A, which grants to the Department of the A rmy (Permittee) by the Commissioner of Education (Permitter) the use of Pence Elementary School at FLW, M issouri, for A rmy Child Care Center, for 5-year term, beginning 1 J uly 1980 and ending 30 J une 1985 (see A ppendix D). 
- $\quad$ Letter dated A pril 26, 1994

Subjects: 1. Return of Pence School B uilding

The W aynesville School District once again requests the return of the Pence School B uilding for use by the district. The B oard realizes the Army is constructing a child care facility which was discussed with us more than 10 years ago. According to a conversation with General Ballard, that facility should be completed in mid-year 1995.

1. Purpose: To provide information on ownership and return of control of the building being occupied by Pence Child Development Center.

\section{Discussion.}

a. The land under Pence has been under Department of the A rmy lease to the Commissioner of E ducation since 1953. The building was constructed by the R-VI school district and is owned by the district. The same principle applies to the other 6 school buildings on post.

b. In 1980, the installation requested use of the building as a CDC and was issued a use permit in that year. The permit was renewed over the course of the intervening years until J une of 1990.

c. In M arch 1990, the school district requested return of the building (based on anticipated construction of the new CDC effective 1 J uly 1991). The occupation permit has not been renewed and we are currently occupying the building under sufferance of the school district.

$d$. The school district plans to re-occupy the building as a school housing general and expanded special education missions upon completion of the new CDC in 1995 (A ppendix E).

- November 15, 1994 letter from Waynesville R-VI School District

During the decade of the 80 s, many specific improvements were made in all the buildings we operate on FLW. At this time, Pence School leased to the A rmy for a Pre-School child care facility. It appears that with the completion of a new child facility for the FLW community, this school district will reacquire Pence building.

- Pursuant to the Resolution of the W aynesville R-VI School Districted dated may 18, 1998, and December 20,1999, to obtain ownership of the Pence Elementary School located within FLW, M issouri, and in accordance with section 8008 (b) of the Elementary and Secondary Education A ct of 1965, formal request is hereby made for the transfer of the school facility from the U nited States of A merica, U.S. D epartment of Education to the W aynesville R-VI School District (see A ppendix F).

- Permit Termination Agreement signed and dated 2001

for D epartment of E ducation Schools

Located on F ort Leonard Wood

Pulaski County, Missouri

Is made by and between the Secretary of A rmy (Permittor) and the Department of Education (Permittee) effective upon the date of execution by both parties.

Whereas: The Secretary of the A rmy granted seven separate permits to the Department of Education to use and occupy, for school purposes, seven separate parcels of land on the FLW M ilitary Installation, M issouri, between 5 A ugust 1953 and 1 A pril 1962; and

Whereas: The Department of Education in accordance with 20 U.S.C. Section 7708, has proposed to terminate the seven existing permits located on the FLW M ilitary Installation, M issouri, and transfer all capital improvements to the W aynesville R-VI School District by individual "quit claim deed" over a period of time (see A ppendix $G$ ).

- According to Resolution W aynesville R-V 1 B oard of E ducation Pence Elementary School in J anuary 2011, it was stated "to terminate and rescind the ground lease on the Pence Elementary School on Fort L eonard W ood and in the quitclaim by the W aynesville R-V 1 School district to the appropriate governmental entity of the United States. The quitclaim deed granted by the school district will include 
language that the building is transferred in its "as-is" condition, the School District makes no warranties as to the condition of the building, an assumes no liability of any type after the transfer, including for the existence of materials such as friable and non-friable asbestos contained in the transferred building."

- A letter dated F ebruary 2011 from the W aynesville R-V 1 School District; office of the Superintendent stated that "The Pence School building located on Fort Leonard W ood has provided the School District and many on-base families with years of service. However, the usefulness of the Pence School building to the School District has ended. B ecause of its age and structural obsolescence, the building premises can no longer serve the School District's needs. Therefore, the School B oard requests that the ground lease dated $M$ ay 1, 2006, (copy of which is enclosed) and any amendments or additions thereto be terminated by written mutual agreement. A dditionally, the School District requests that the A rmy accept title to the building premises. Finally, it is requested that the A rmy assume the cost of demolition of the building.

- Furthermore, an email dated J anuary 4, 2011, requested verification that the school building was not characterized or registered as a historical structure by the M issouri Office of Historical Preservation. The website that provides a registry listing of the designated "historical" buildings in Pulaski County determined that the Pence School building was not included in that list.

Throughout the lease arrangements, the A rmy and the district have been able to work cooperatively to make al terations to the Pence Building.

According to the Real Property Card for Building 6824, the structure was entered into FLW Integrated Facilities System in February 1978.

T wo environmental surveys have been conducted on Building 6824; Asbestos Survey at Pence School in December 2010 by Paragon B usiness Solutions and Management P Ian AHERA Information and Training by Roth A sbestos Consultants Incorporated.

A rehabilitation of the building for a child care center occurred in $M$ ay 1980 . A ccording to the rehab drawing (see Drawing 10), the construction notes state to cut out a rough opening and frame in for a new $3^{\prime}-0^{\prime \prime} \times 6^{\prime}-8^{\prime \prime}$ hollow metal door with panic hardware. However, according to the Real Property card, the doors and windows were not replaced until 1986. A lso at this time, the original five-pane steel awning windows were removed and replaced with anodized bronze aluminum windows, the wood soffit was removed and replaced with new metal fascia and soffit, and the exterior light fixtures were replaced.

The building underwent major kitchen renovation, upgrading the interior and all new kitchen equipment in 1999.

The building was vacated by the School District in 2005-2006. FLW began utilizing this facility for law enforcement training when needed.

The school building was named after M G Arthur W illiam Pence (pictured below). M ajor General Pence was born in 1898 and died in November 1954. He was an Ohio River Division Engineer and held Army Engineer posts in M ontana and M ississippi. He served in W orld W ar I, W orld W ar II, the K orean W ar, and was the Commanding General of the 6th A rmored Division at FLW from 1953-54.

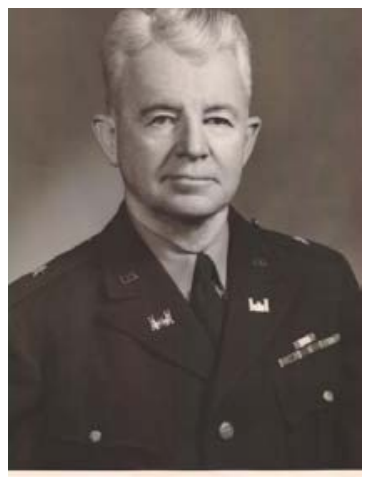




\section{INTE GRITY}

Building 6824, Pence Elementary School, is in good condition; however, the building is currently vacant. B uilding 6824 has undergone changes since it was constructed in 1954. The exterior has been altered with replacement windows and a new window pattern to include door opening modifications, replacement entry doors with sidelights and transoms, new metal fascia and soffit, and a one-story brick addition constructed to enlarge the original cafeteria. Building 6824 no longer conveys some of its original construction materials, though its function has remained constant as an education/child care facility. There have been tests conducted on the materials of the building, such as lead paint and asbestos tiles, and it was concluded that both hazardous materials were found within Pence Elementary School.

\section{Exterior:}

Original Architectural F eatures

Replacement F eatures

\begin{tabular}{|l|l|}
\hline L-shaped footprint & $\begin{array}{l}\text { Slightly modified with the construction of an } \\
\text { addition on the southwest corner to enlarge the } \\
\text { original cafeteria }\end{array}$ \\
\hline Concrete block construction with a tan brick veneer & -- \\
\hline Flat built-up roof & -- \\
\hline Rows of five-pane steel awning windows & $\begin{array}{l}\text { W indows have been removed and replaced with } \\
\text { one-over-one anodized bronze aluminum win- } \\
\text { dows and the window pattern has been modified } \\
\text { to include a new door opening in one of the orig- } \\
\text { inal window openings }\end{array}$ \\
\hline $\begin{array}{l}\text { Three-light steel entry doors with sidelights and tran- } \\
\text { soms }\end{array}$ & $\begin{array}{l}\text { Removed and replaced with anodized bronze } \\
\text { aluminum and glass doors, sidelights and tran- } \\
\text { soms }\end{array}$ \\
\hline M etal and concrete canopies over entries & M odified with metal sheet coverings \\
\hline Wood fascia and soffit & M odified with metal \\
\hline Playgrounds & $\begin{array}{l}\text { M ost of the playground equipment is intact with } \\
\text { the addition of newer playground equipment }\end{array}$ \\
\hline
\end{tabular}

Interior:

Original Architectural F eatures

11 classrooms, 1 music and art room, 1 primary
room, 4 toilet rooms, two janitor rooms, 1 health
room, 1 office, 1 teacher's room, 1 kitchen with pan-
try, 1 boiler room, and 1 cafeteria

Concrete block walls

Intersecting corridors

A sbestos tile floors

Classrooms with framed chalkboard, framed tack board, wood shelving unit, an open coat "cubby", a small storage closet, and a workstation with a sink
Replacement F eatures

The health room and office dividing wall has been removed to make one large room and an addition was constructed on the south end of the original cafeteria

$--$

Some flooring removed and replaced with carpet

The majority of these features are intact with slight modifications, such as removed chalkboards, replacement countertops in workstations, and newer door openings cut into the wall of the coat "cubby" to connect the adjoining rooms 


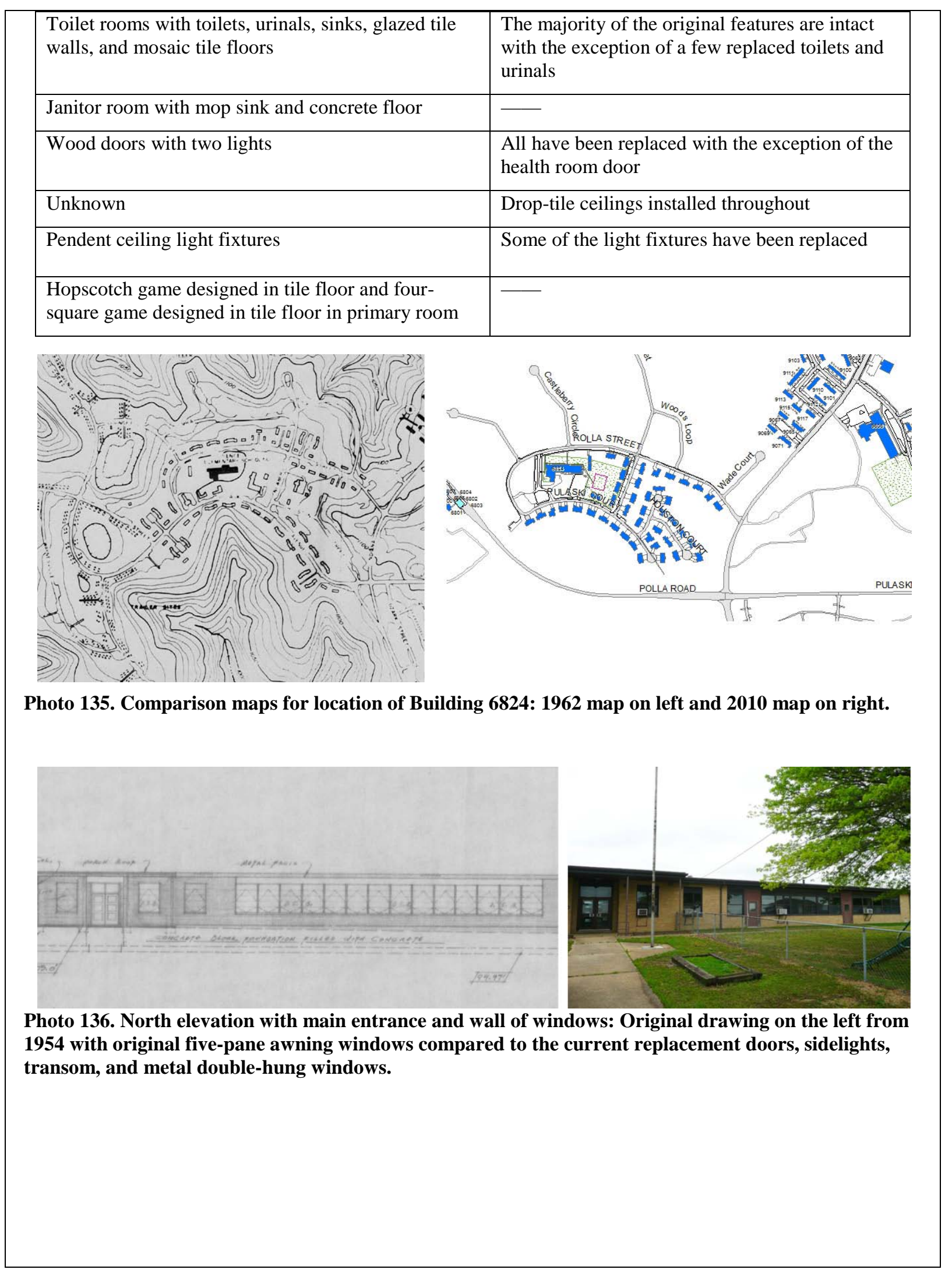




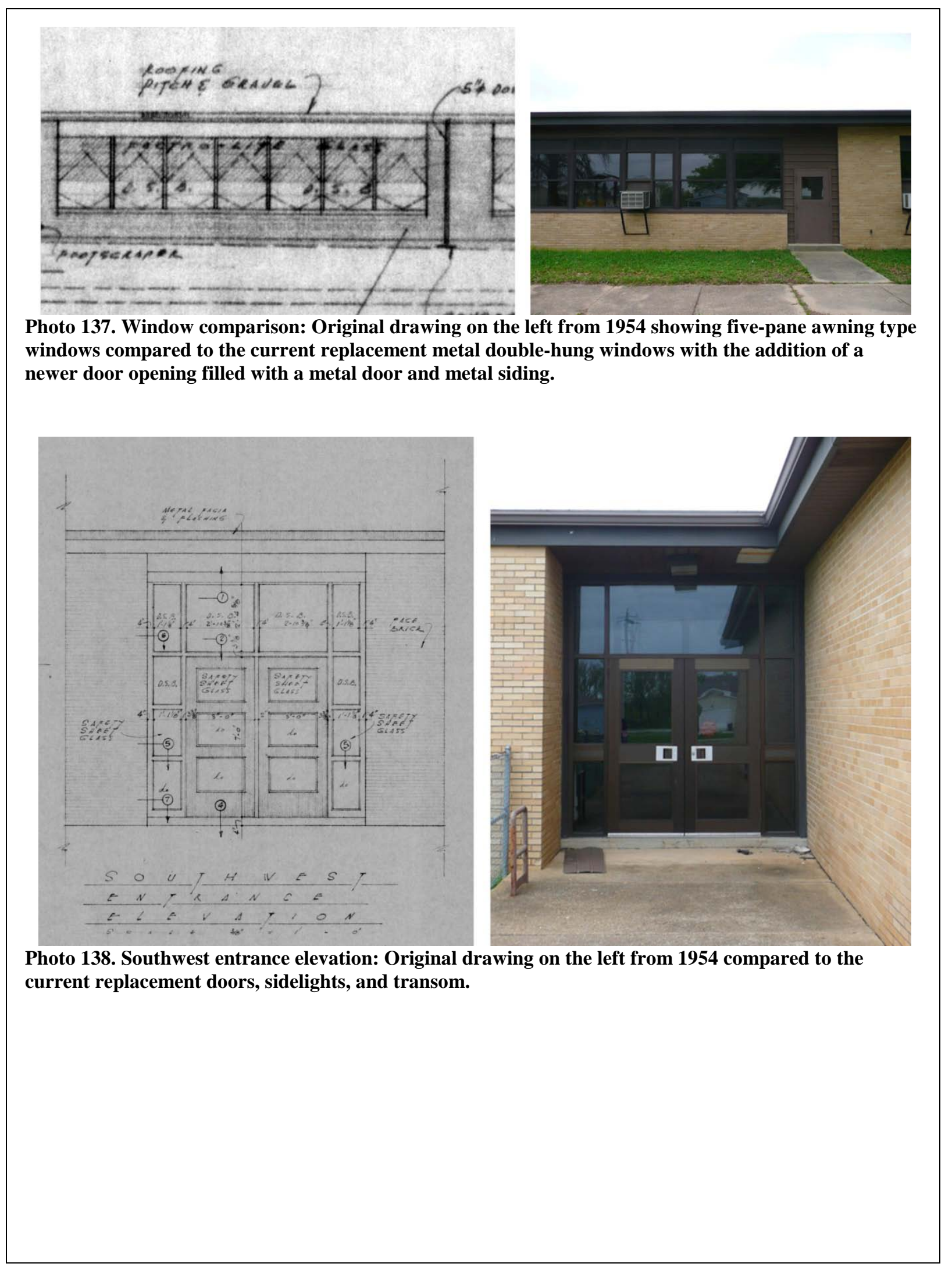



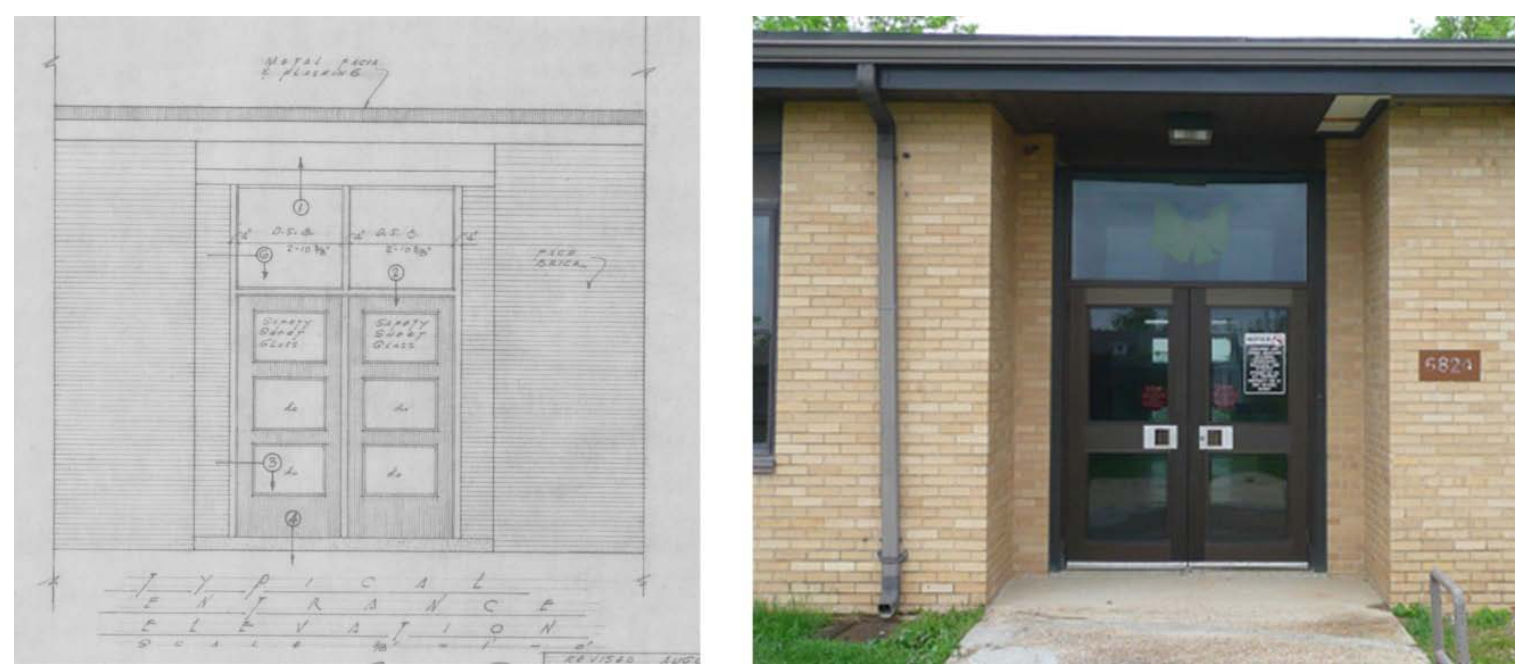

Photo 139. E ntrance on south elevation: Original drawing on the left from 1954 compared to the current replacement doors and transom.
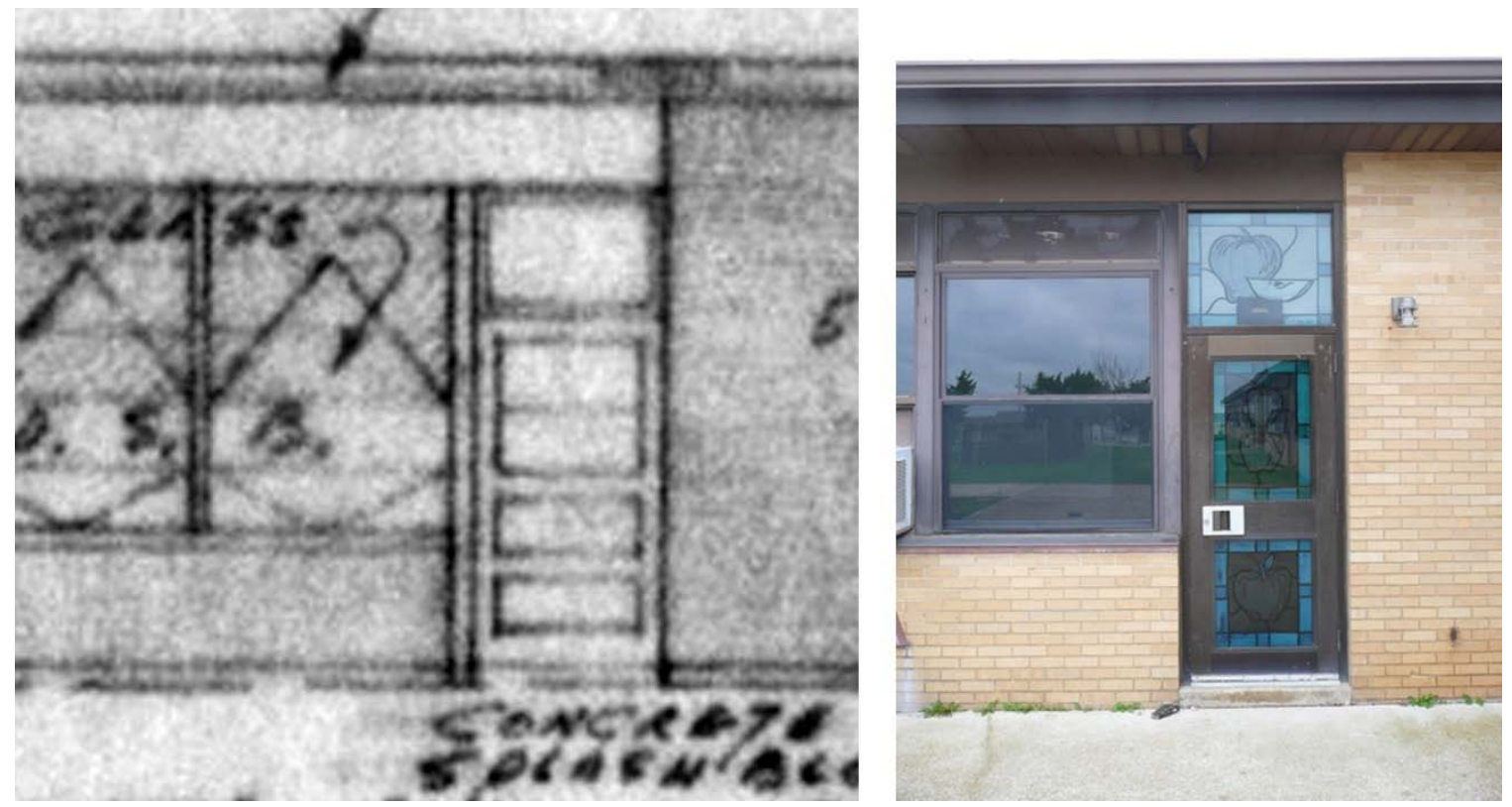

Photo 140. E ntrance into the cafeteria on the east wall: Original drawing on the left from 1954 compared to the current replacement door, transom, and windows on the right. 

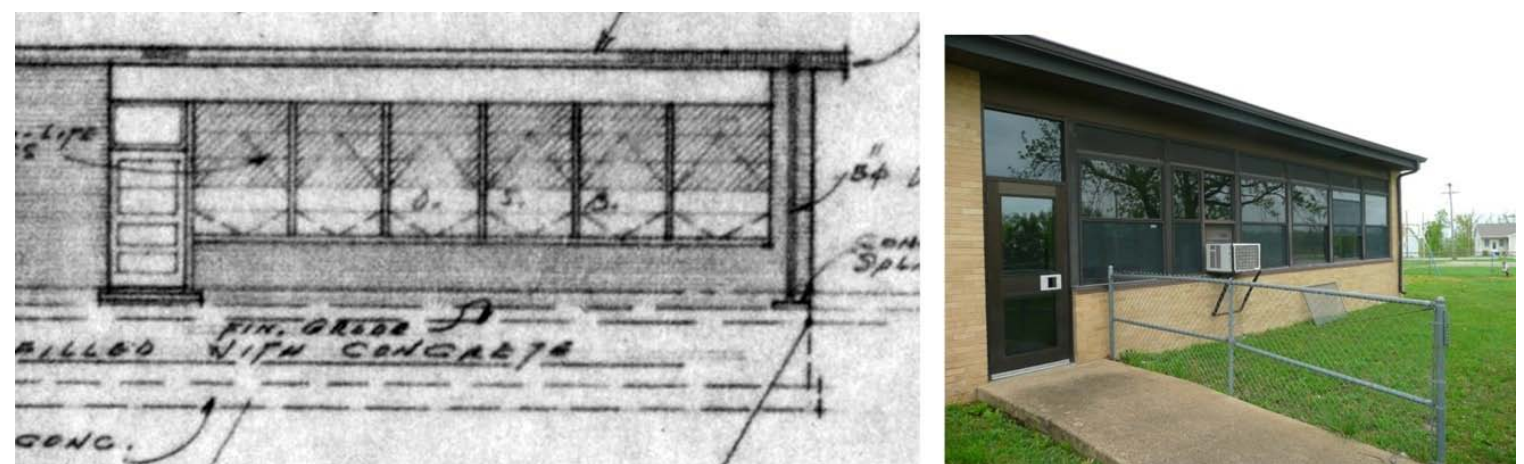

Photo 141. Right side of the west elevation: Original drawing on the left from 1954 compared to the current replacement door, transom, and windows on the right.
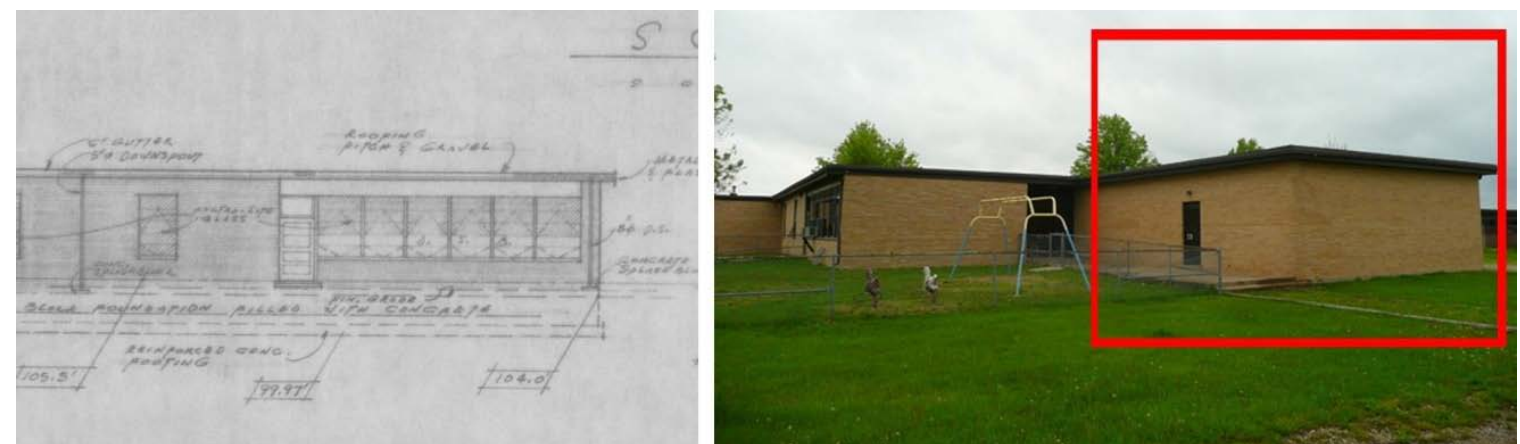

Photo 142. C afeteria addition: O riginal drawing on the left from 1954 with no expanded cafteria space compared to the current size of the cafertia with the construction of an addition, highlighted in red.
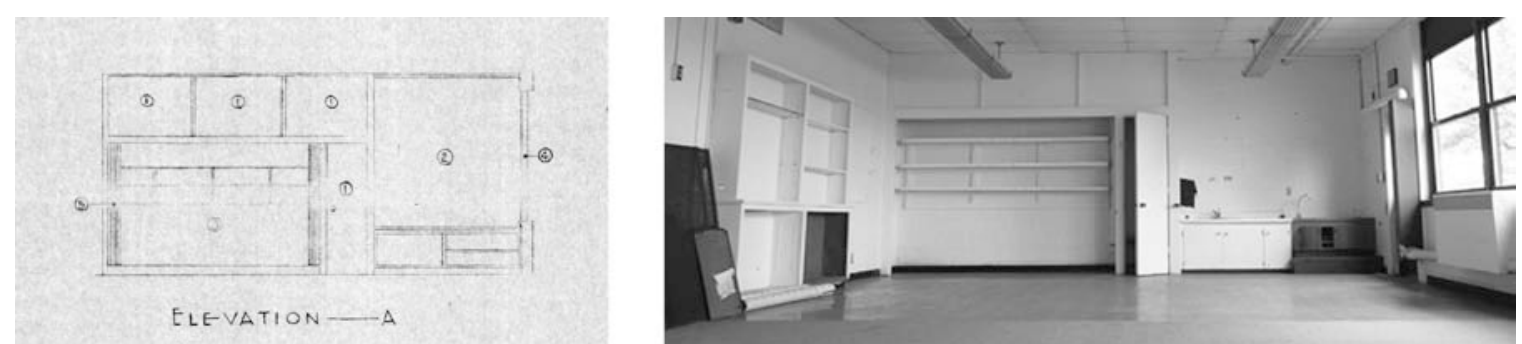

Photo 143. Classroom detail of coat "cubby" area, teacher's storage closet, and workstation with sink: Original drawing on the left from 1954 compared to the current condition of a typical classroom detail on the right. 


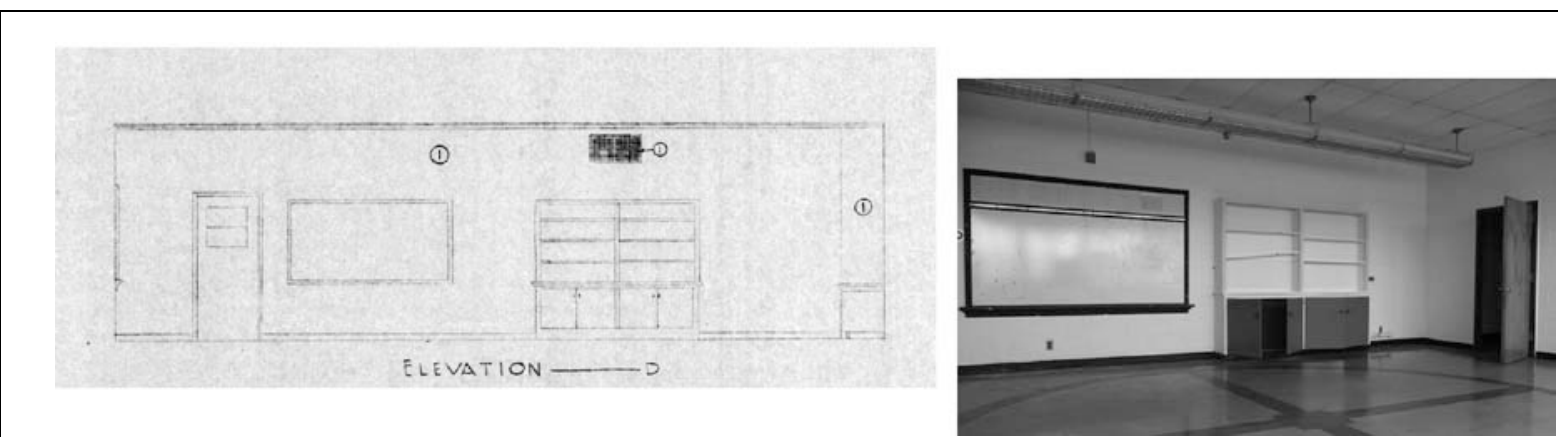

Photo 144. Classroom detail of storage shelf and tack board: Original drawing on the left from 1954 compared to the current condition of a typical classroom detail with a replacement whiteboard where the tack board use to be located on the right.

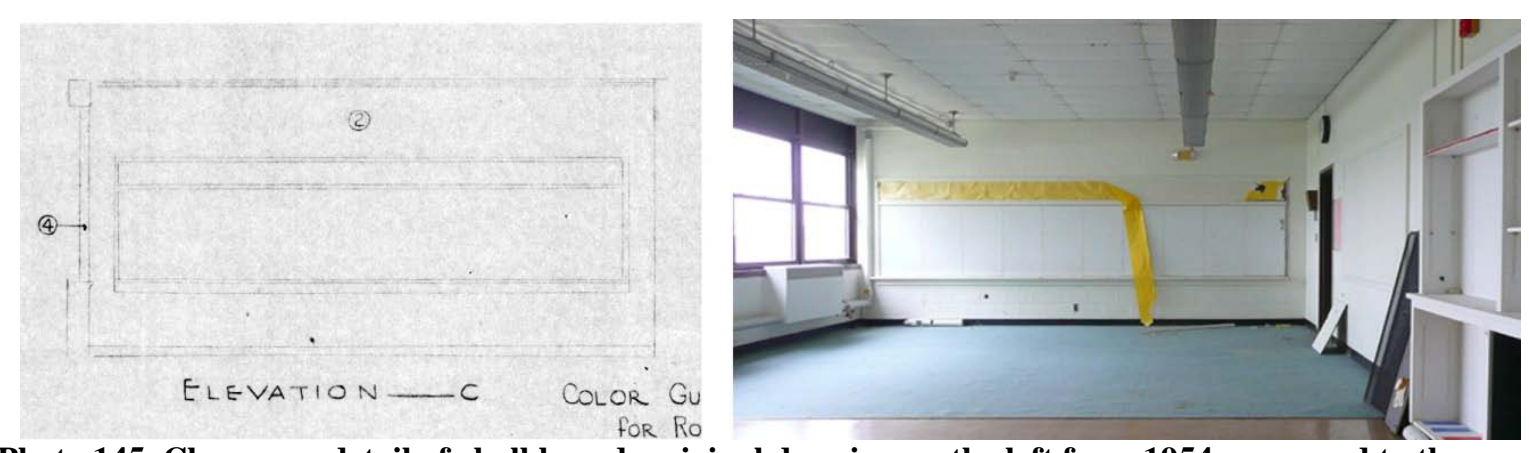

Photo 145. Classroom detail of chalkboard: original drawing on the left from 1954 compared to the current condition in the photo on the right of a typical classroom detail where the original chalkboard has been removed.
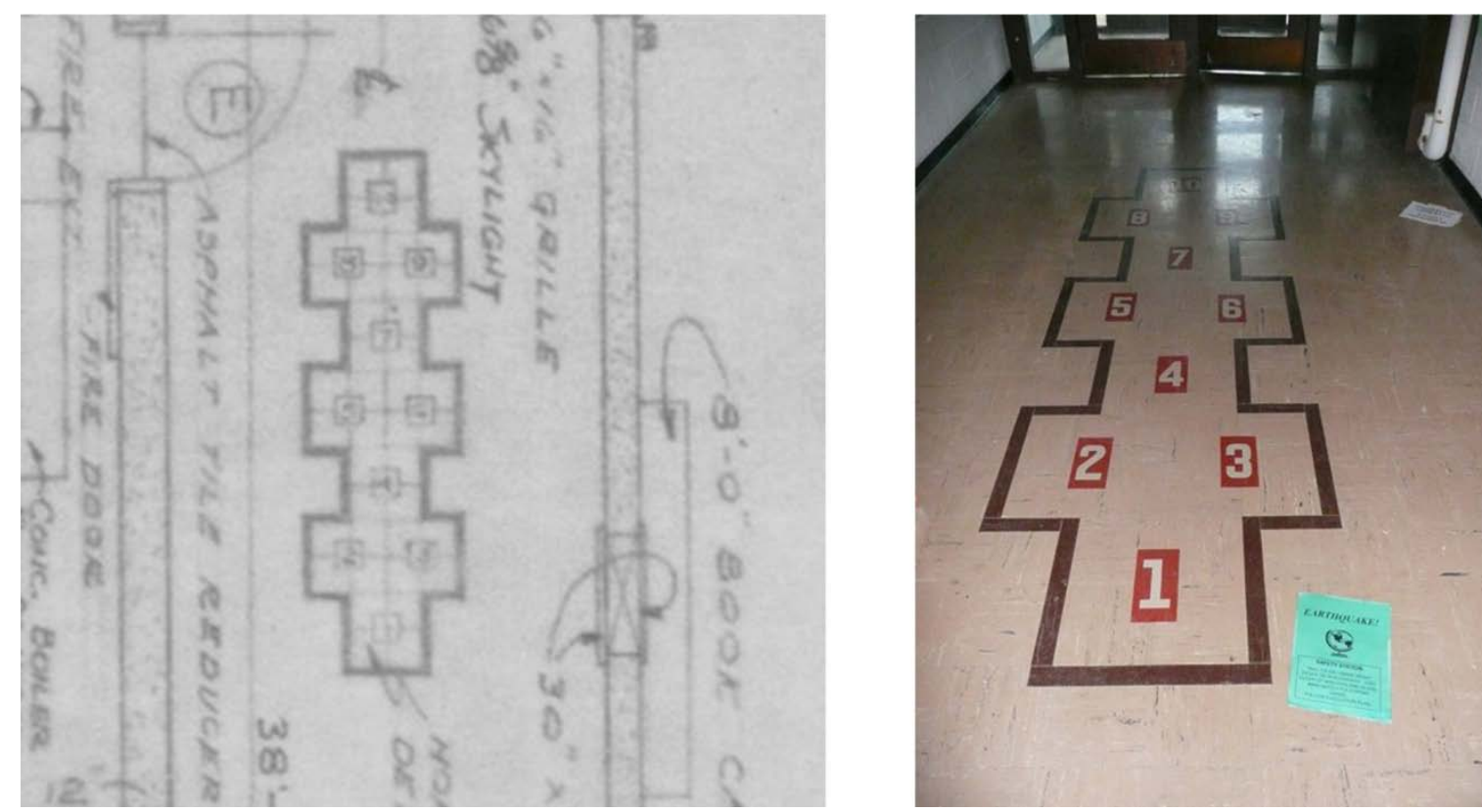

Photo 146. H opscotch detail: original drawing on the left from 1954 compared to the current condition of a hop-scotch detail (location on drawing and actual location are different- see Drawing 3 below). 


\section{SIGNIFICANCE}

Building 6824, Pence Elementary School, is not associated with any particular event that is significant in the history of the overall Cold War or in the history of FLW. The building was constructed to meet the growing needs of the school-age child living on post.

\section{DETERMINATION OF CONTRIBUTING/NONCONTRIBUTING STATUS}

It is the determination of this report that Building 6824, Pence Elementary School, is NOT eligible to the National Register of Historic Places (NRHP) since it could not be related to a significant event for Criterion A, a significant person for Criterion B, a significant architect or design for Criterion C, nor is it likely to yield information potential for Criterion D. 


\section{DRAWINGS}

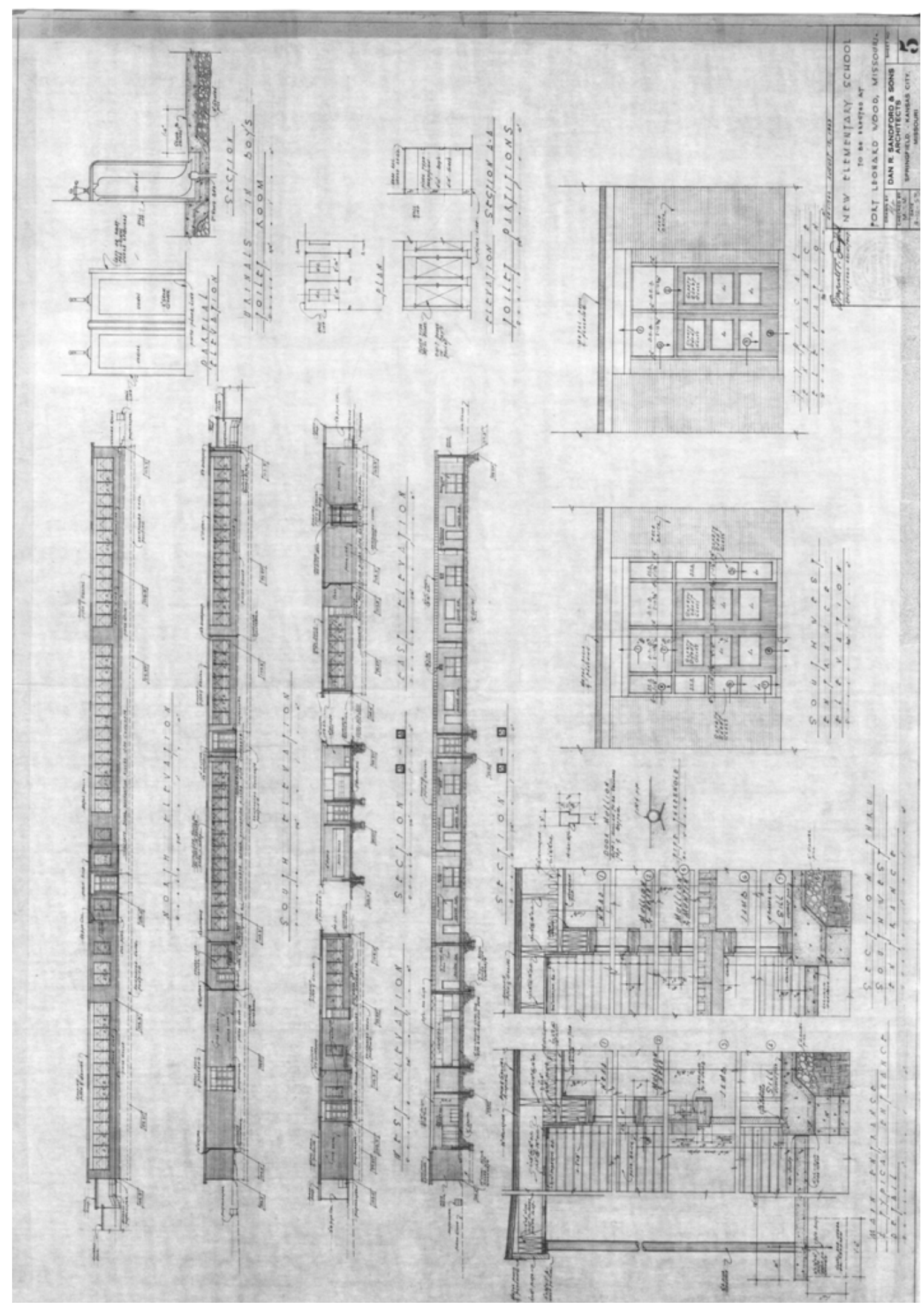

Drawing 1. E levations and sections, 1954. 


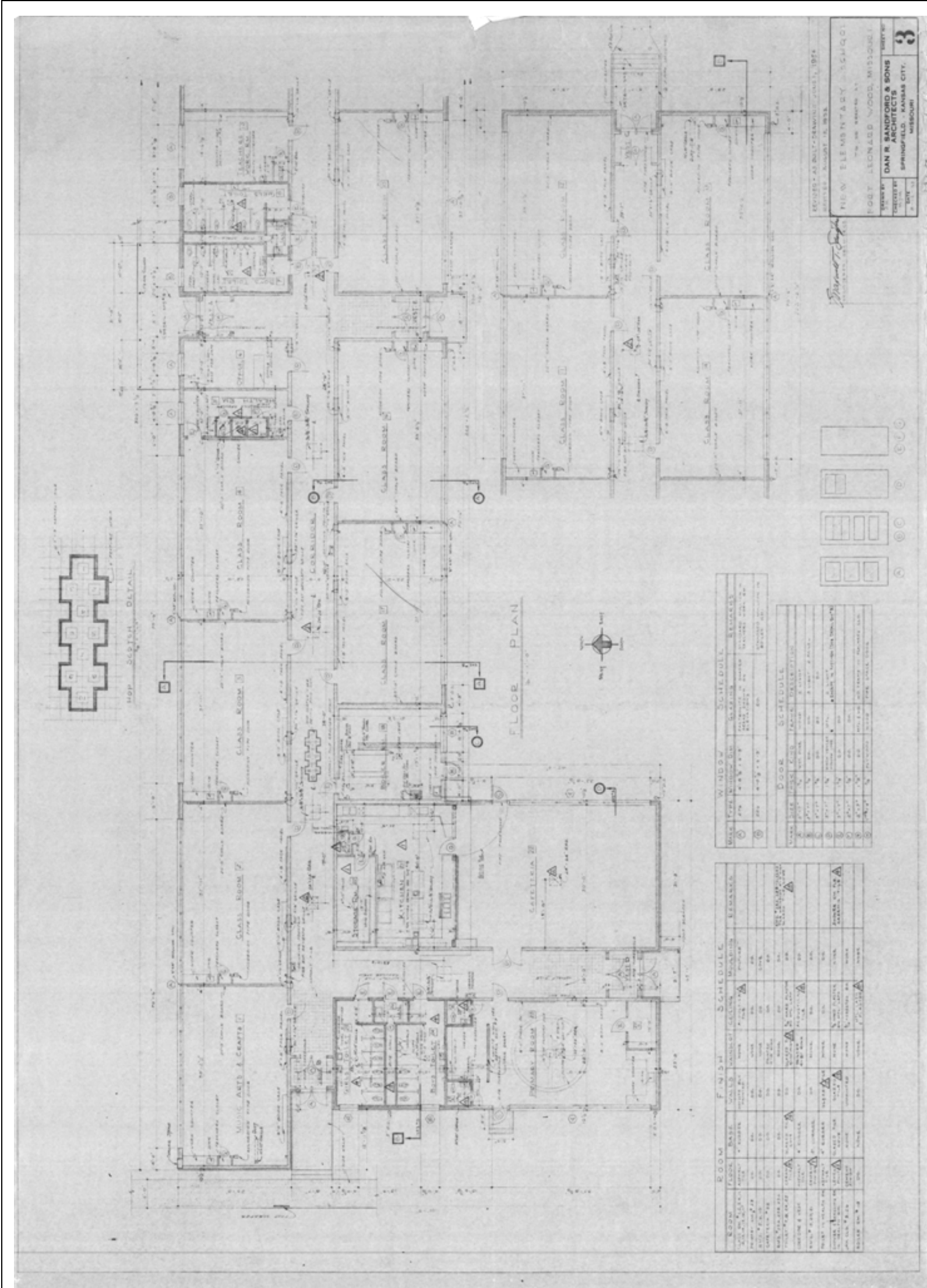

Drawing 2. R evised floor plan, 1954. 


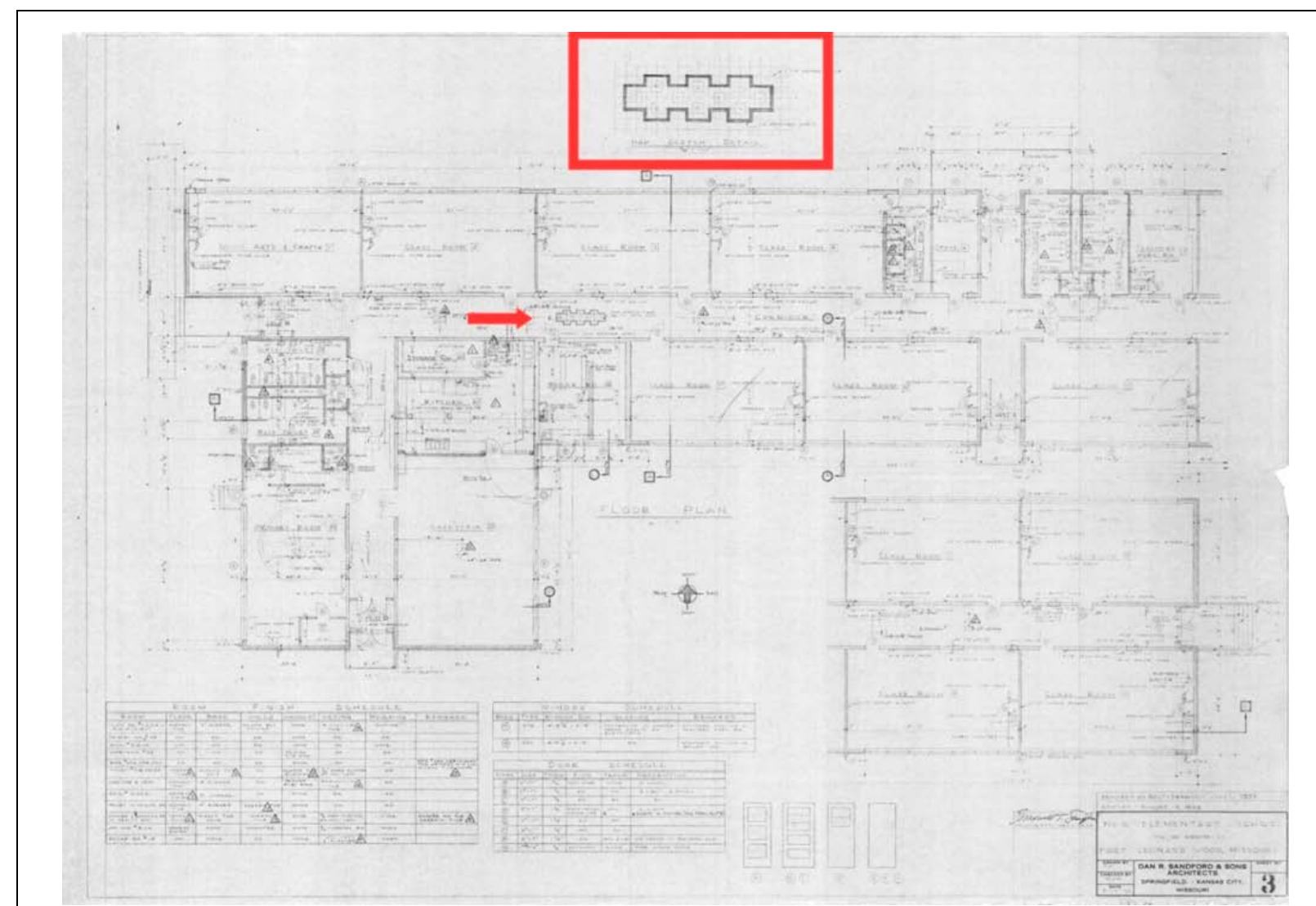

Drawing 3. 1954 floor plan depicting the original location of the hopscotch detail in the tiled floor.

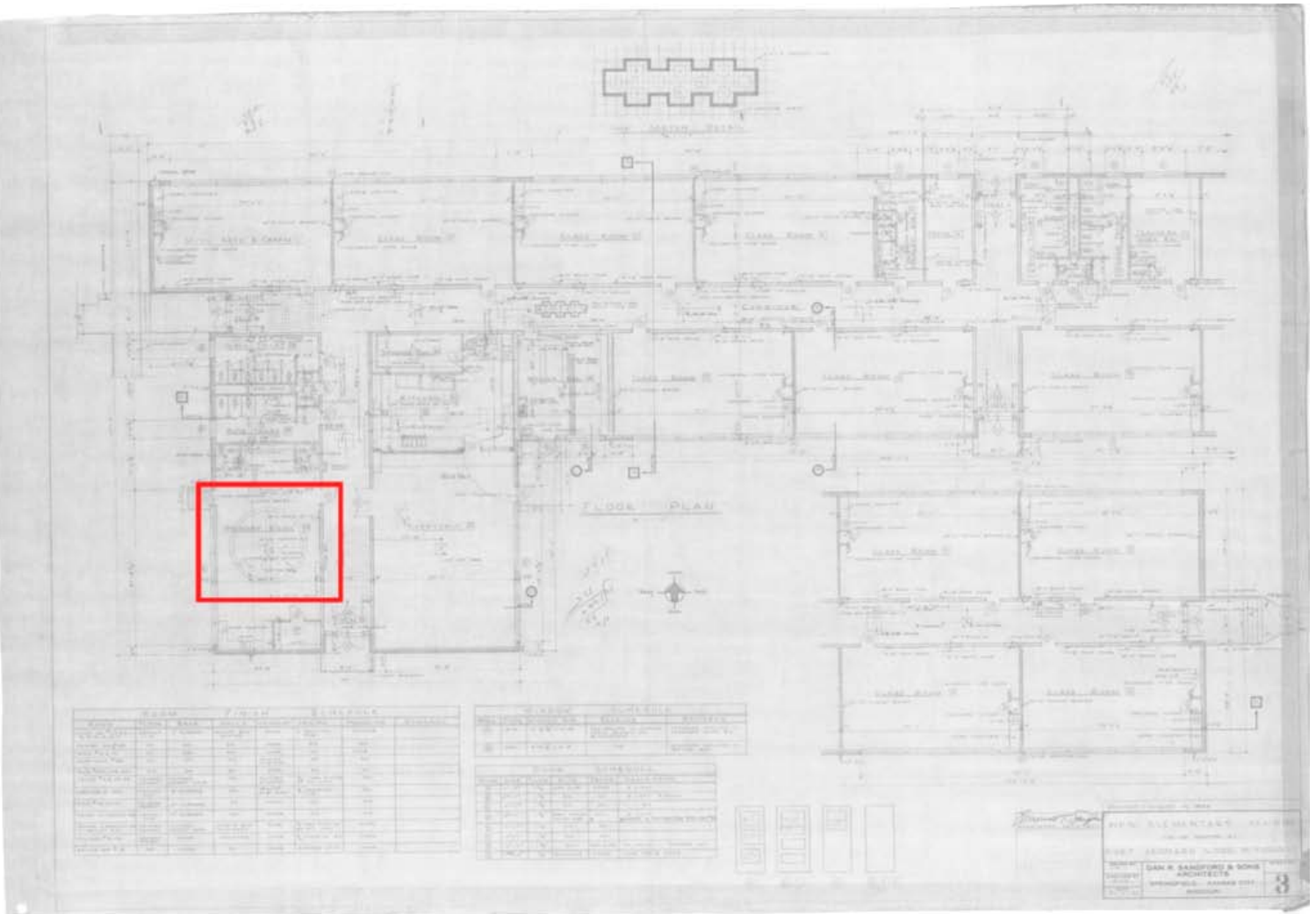




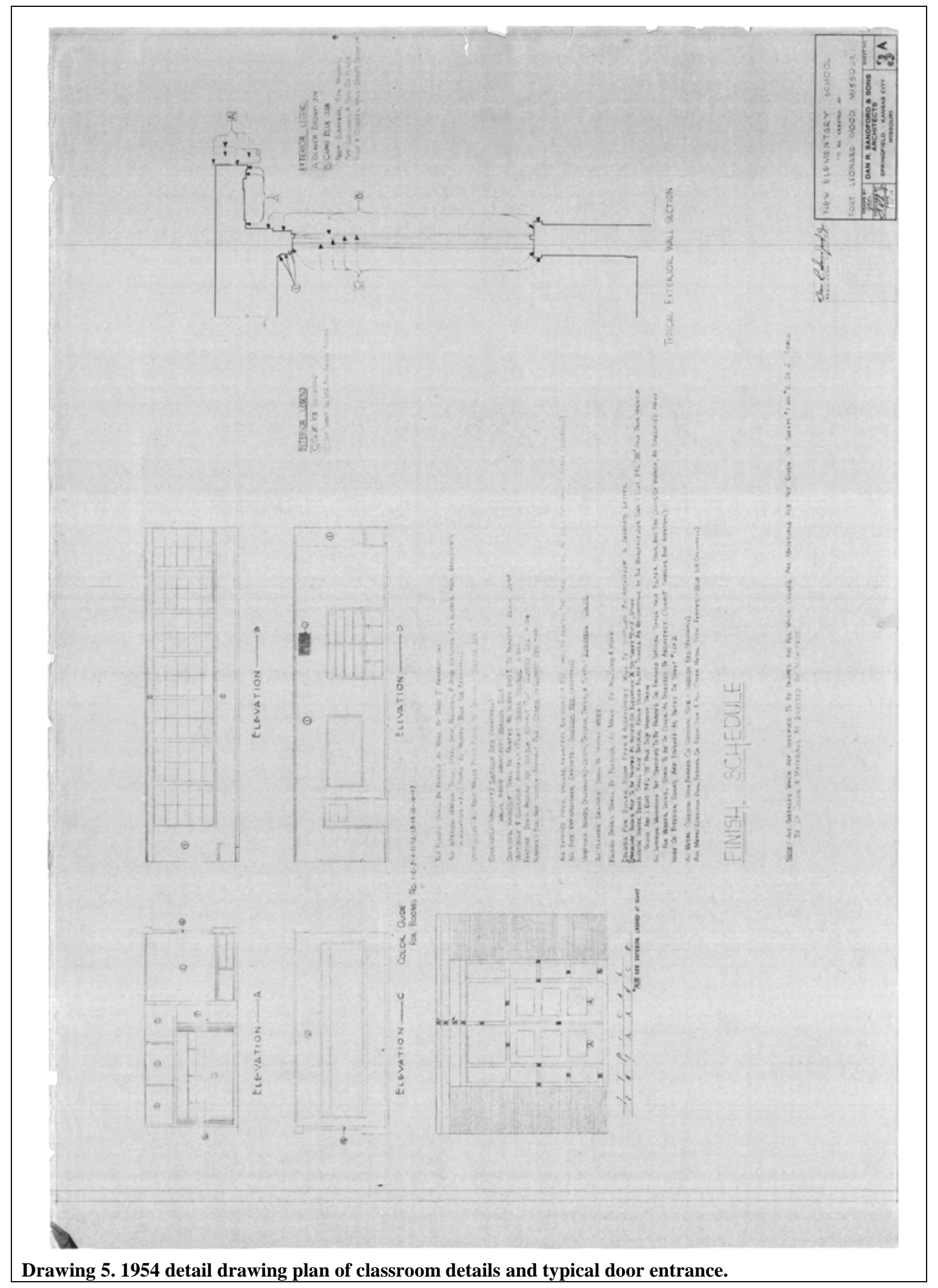




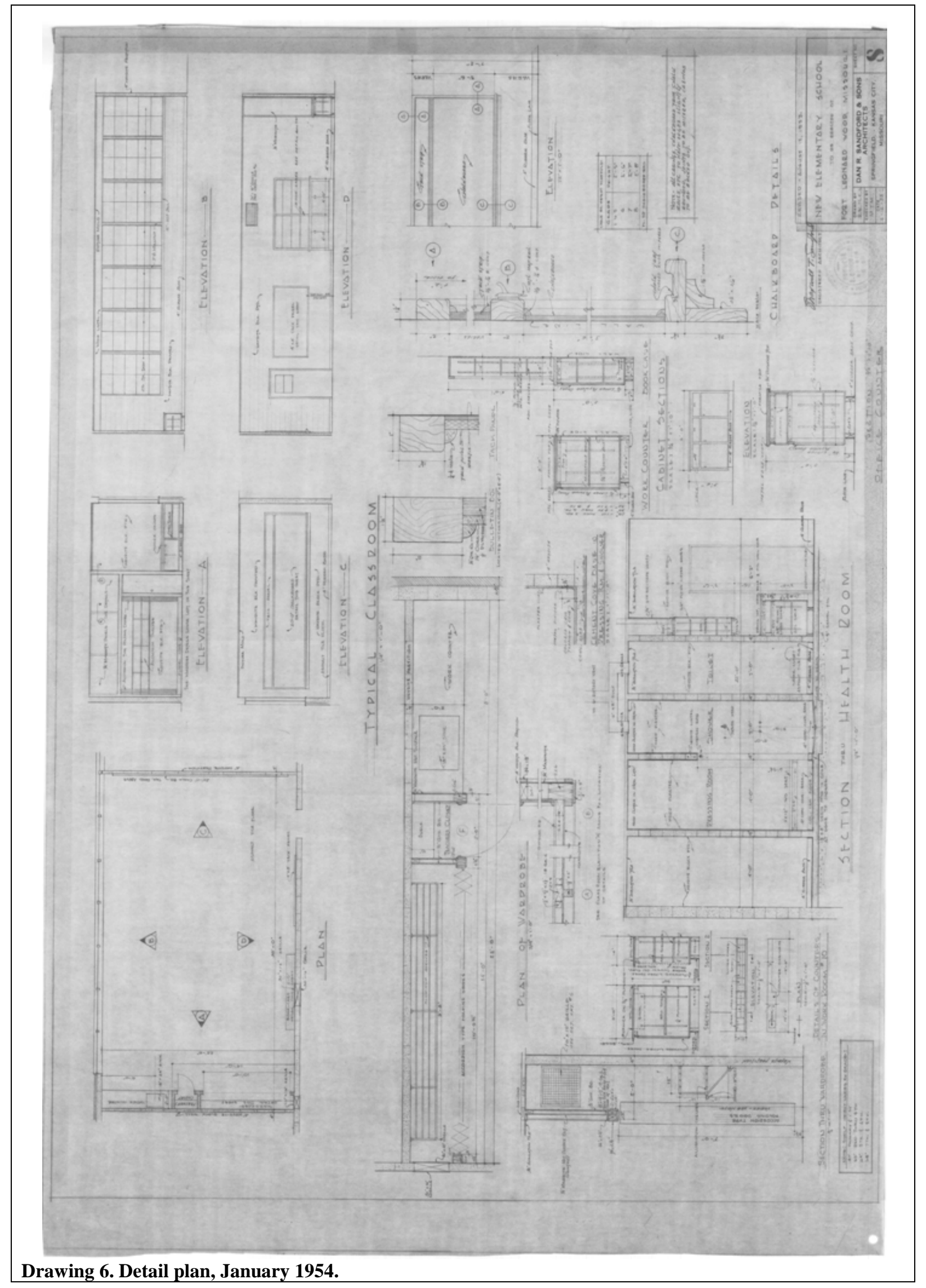




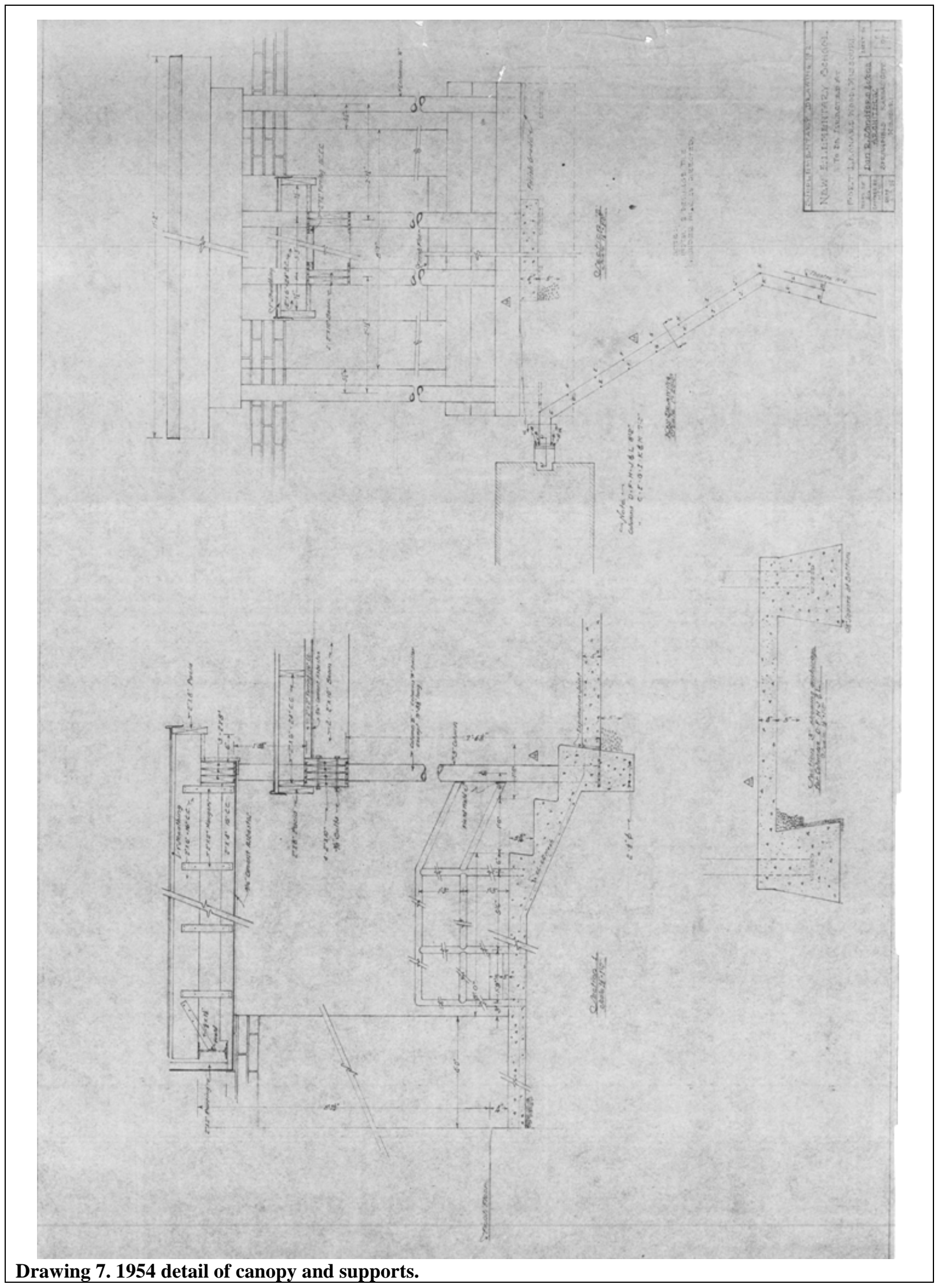




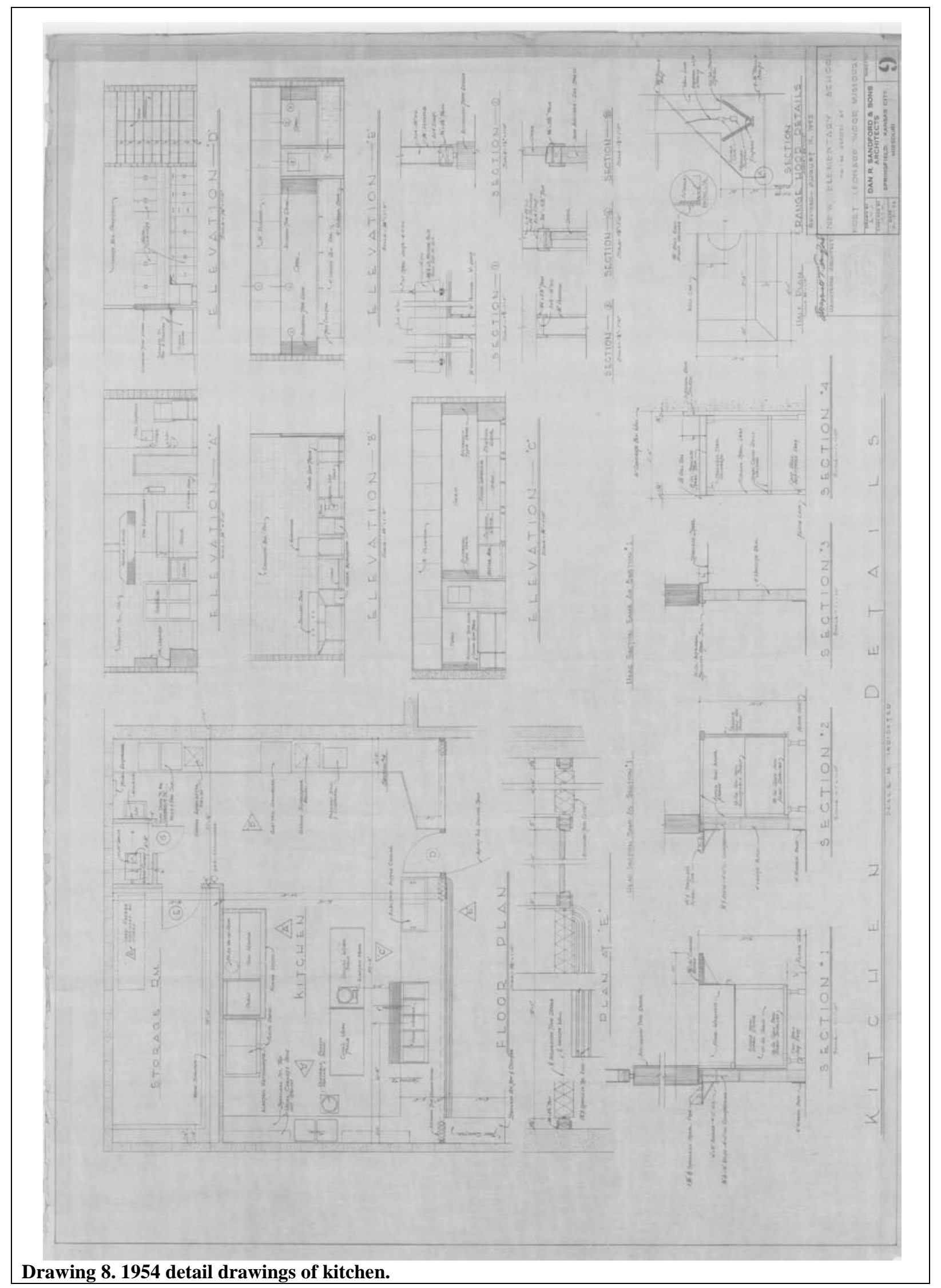




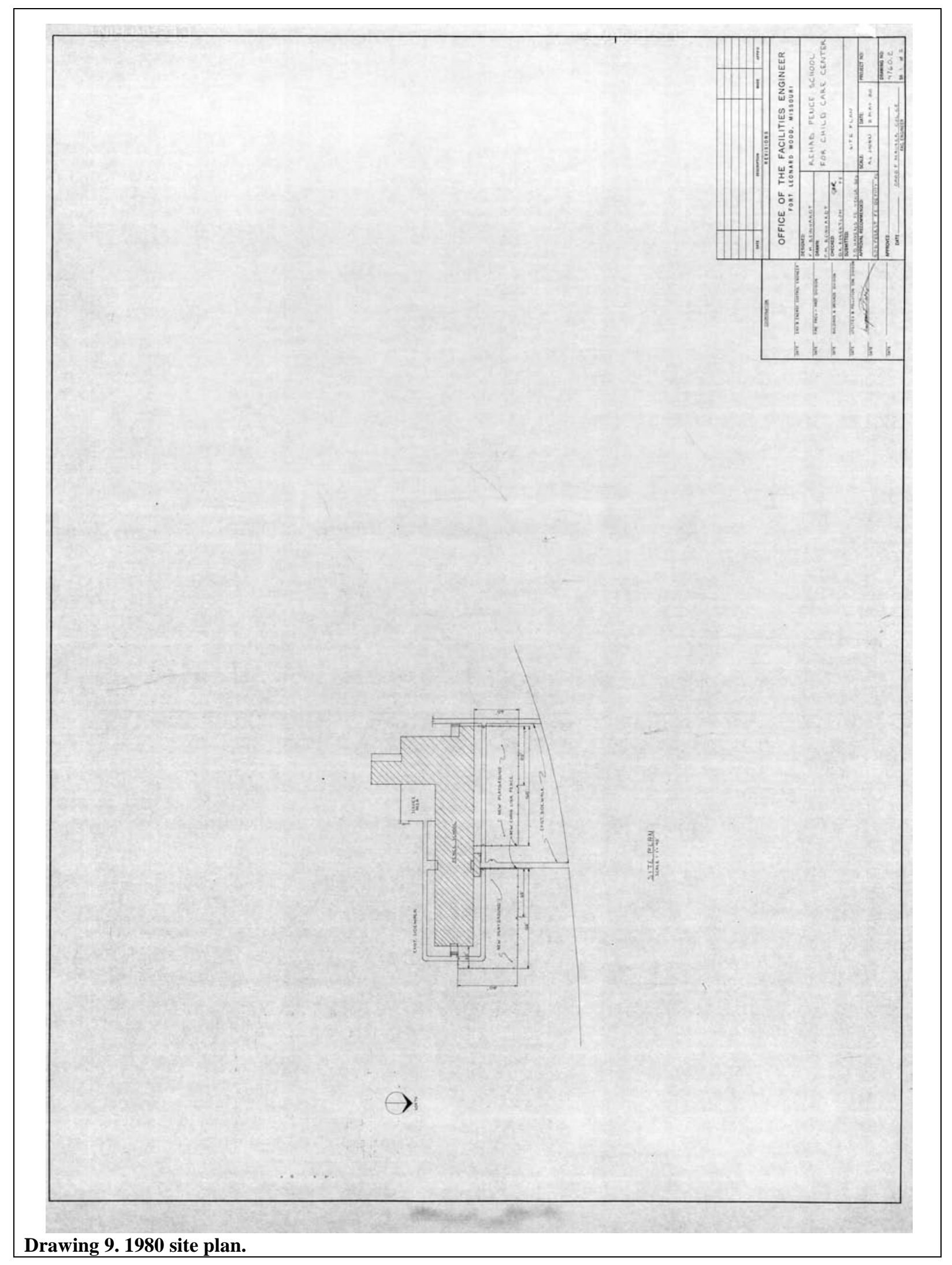




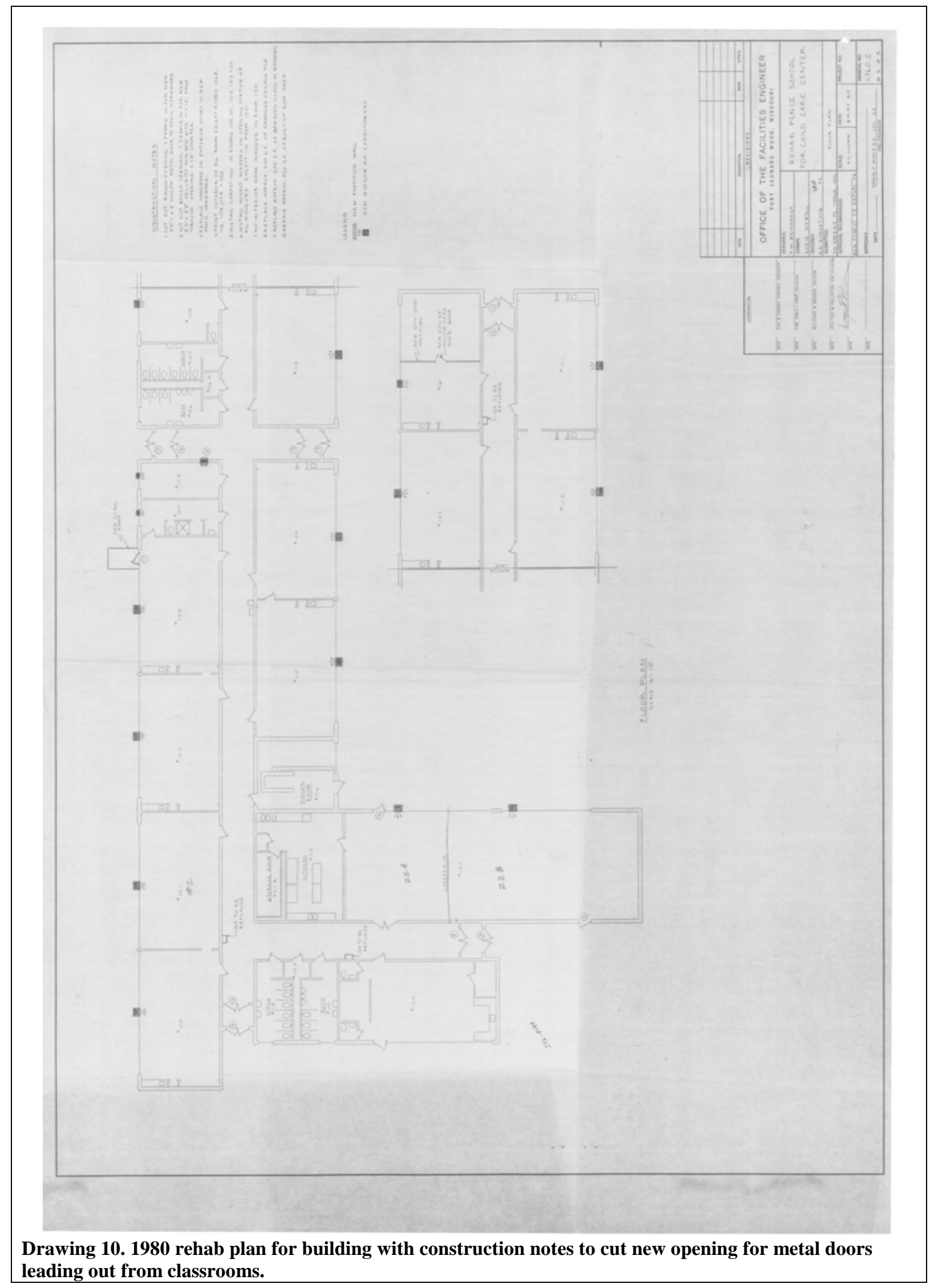




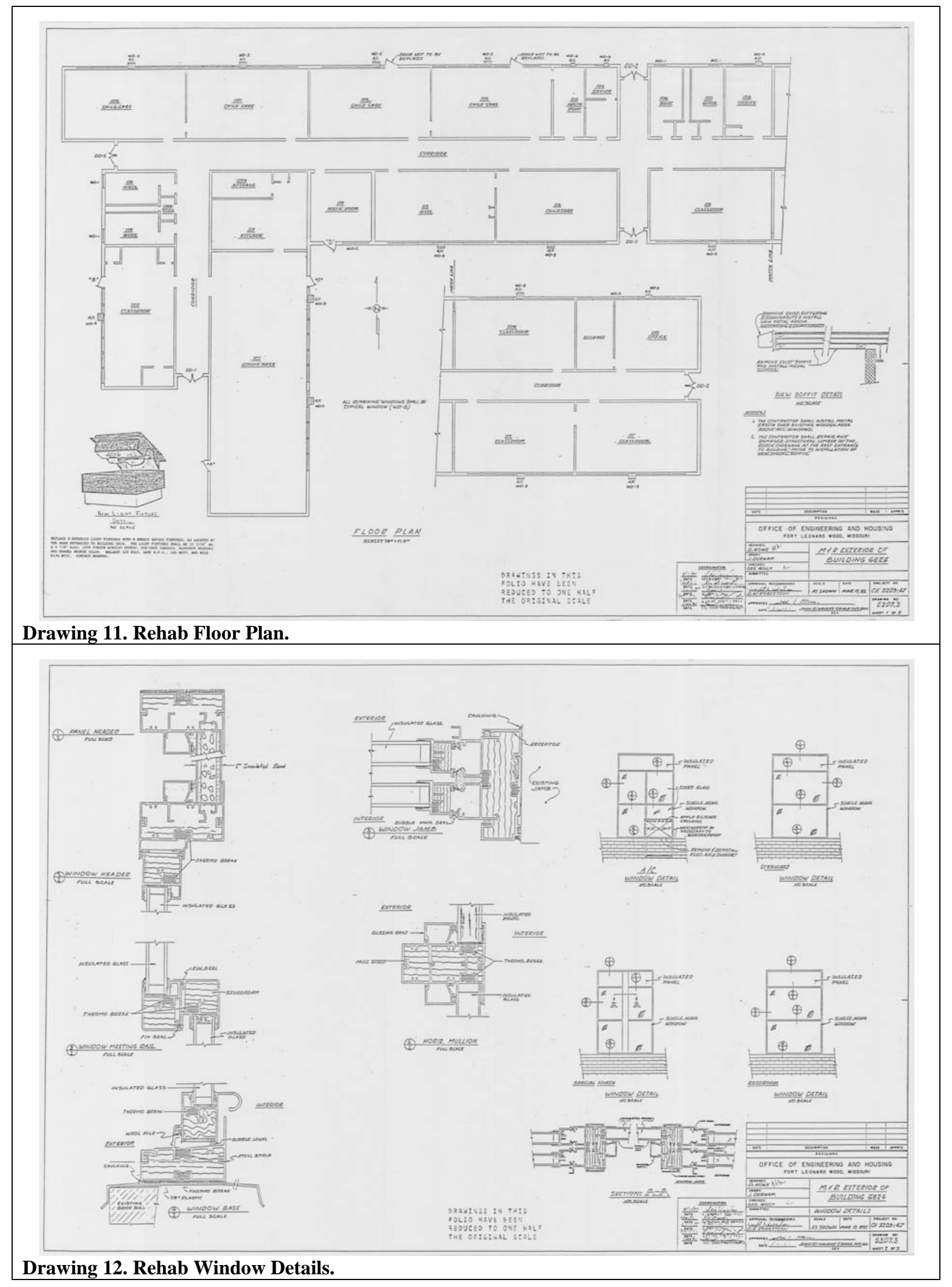




\section{References}

Atkin, J. Myron, and Ernest R. House. 1980. "The Federal Role in Curriculum Development, 1950-80." Washington, DC: National Institute of Education of the Department of Health, Education and Welfare.

Brubaker, C. William. 1998. Planning and Designing Schools. New York: McGraw-Hill.

Caudill, William W. 1954. Toward Better School Design. New York: F.W. Dodge Corporation.

Christ-J aner, Albert.1979. Eliel Saarinen Finnish-American Architect and Educator. Chicago: University of Chicago.

"Crow Island Revisited."1955. Architectural Forum, Oct., 130- 37.

Edging, Richard et al. September 2003. Fort Leonard Wood Integrated Cultural Resources Management Plan FY 2002 to 2006.

Graves, Ben E. 1993. School Ways: the Planning and design of America's Schools. New York: McGraw-Hill.

Helmick, J ohn, and Lisa Hudson. 1997. "A Study of Schools Serving Military Families in the U.S.: Education Quality, Federal Administration, and Funding." Arlington, VA: Defense Manpower Data Center.

"A New Kind of High School." 1955. Architectural Forum, Oct., 146- 49.

Loechl, Suzanne K., Susan I. Enscore, Megan Weaver Tooker, and Samuel A. Batzli. 2009. Guidelines for Identifying and Evaluating Historic Military Landscapes. Technical Report ERDC/ CERL TR-09-6. Champaign, IL: Engineer Research and Development Center, Construction Engineering Research Laboratory (ERDCCERL).

"Orientation Affects Cost and Design." 1954. Architectural Record, Feb. 165-71.

Roberts, Larry. 2008. "History of Fort Leonard Wood." Maneuver Support, Summer 2008, 4-6.

Rydeen, J ames E. 2008. "Facility Planning: Learning from the Past." American School \& University. 01 May. Accessed 08 Feb. 2010.

<http:// asumag.com/Construction/planning/learning_past_perkins/ \#>.

Sanders, Luther W. n.d. "Profile of a Significant School: Clarksville-Montgomery County High School." Clarksville, Tennessee: School Planning Laboratory, University of Tennessee.

Smith, Adam, Susan Enscore, Karen Zimnicki, and Elizabeth Campbell. 2003. Fort Leonard Wood Building Survey 1941 to 1956. Unnumbered report. Champaign, IL: US Army Engineer Research and Development Center. 
Smith, Adam, Sunny Stone, Susan Enscore, Marcia Harris, Christella Lai, William Mayer, and J acqueline Wolke. J une 2006. Fort Leonard Wood German POW Stonework Context and Survey. ERDC/ CERL SR-06-30. Champaign, IL: US Army Engineer Research and Development Center.

Smith, Adam. 2007. Fort Leonard Wood Rolling Pin Barracks and Associated Building: Context and Inventory. ERDC/ CERL SR-07-8. Champaign, IL: US Army Engineer Research and Development Center.

Tanner, C. Kenneth, and J effery A. Lackney. 2006. Educational Facilities Planning: Leadership, Architecture, and Management. Boston: Allyn and Bacon.

Taylor, J ames L., Helen K Mackintosh, and Wilhelmina Hill. 1953. “Designing Elementary Classrooms." Washington, DC: U.S. Department of Health, Education, and Welfare.

Tooker, Megan Weaver, Sunny Stone, and Adam Smith. September 2007. Fort Leonard Wood Cantonment Landscape Context, Inventory, and Management. ERDC/ CERL SR-07-21. Champaign, IL: US Army Engineer Research and Development Center.

U.S. Congress. 1950. Impact Aid Program. Public Law 81-874. 30 Sept. Washington, DC: US Congress.

\section{Archival Sources}

Records on file at the Waynesville R-VI School District offices at 200 Fleetwood Drive, Waynesville, Missouri. 


\section{Appendix A: Legal Land Description}


Description of Land:

The area alloeated for construction of an elementary scheol at Fort Leonard Wood, Missouri, consists of a tract of land lyling in the housing area bounded as follows: South and Bast of Rolla Street, North of Pulaskl Stroet and West of Newburg Street. Hore particularly bounded as follows: South of Rolla 8 treet, Bast of the Commissary, Bldg. \#52, Iarth of the Post Exchange, Bldg. 125 , West of the Tennis Cousts, and more specifically desoribed as follows:

Beginning at a manhole, located near the West side of Theater $\# 6$, Bldg; 123 and South of the Tennis Courts, satd manhole being South elghty-nine degrees $\left(89^{\circ}\right)$ fifty-three ainutes (53') East, thirty-four and eightmtenths (34.8) feet from the Southeast corner of the boundary, this Southeast corner boing narked with a monumenty thence from this monwent a line forming the Bast side of the boundary, North zero degrees, $\left(0^{\circ}\right)$ thirty minutes (30') West, two-hundred-nineteen (219) feet to the paridits apron on the South side of Rolla Street, thus completing the East ilne of the boundery.

Beginning at the monument on the Southeast cormer of the boundary, thenee vith the East Iine, South eighty-three degrees $\left(83^{\circ}\right)$ thirty-two minutes $\left(32^{\prime}\right)$ West, onehundred-thirty-four feet (13h') to the fence line of the existing parking lot; thence following the parling lot fonce south, South ten degrees $\left(10^{\circ}\right)$ forty-five minutes ( $5^{\prime}$ ) West, sixty-four feet ( $6 h^{\prime}$ ') to a monument being the further point South of the boundary thence a line ruming Wegt of the monument and North of the Post Bxchange, Bldg. \#25, South eighty degrees $\left(B 0^{\circ}\right)$ twenty-two minutes $\left(22^{\prime}\right)$ West, one-hundred-sixty (266') to a monument; thence with this moxument, South eighty-six degrees $\left(86^{\circ}\right)$ two minutes (2') Weat, seventy-eight and five-tenths $(78+5)$ feet to a monument, being the Southwest corner of the boundary; thence with this monument, parallel with and West of the new school and East of the Commissary Bldg. 152 , the West side of the boundary being North five degrees $\left(5^{\circ}\right)$ twenty-nine minutes (29v) West, tuo hundredthirtymone feet (23i') to a monument on Bolla Street, thus completing the survey with Rolla street and parking aproms being the North side of the boundary. 


\section{Appendix B: Department of Health, Education, and Welfare - Termination of Permit 1957}




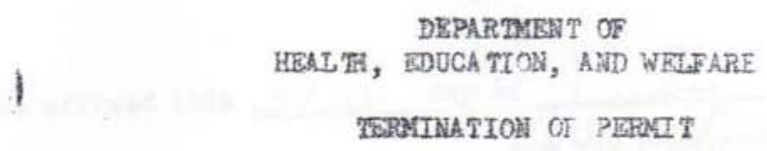

The perait granted by the Comaissioner of Education, Department of Health, Bducation, and Welfare, hereinafter called the Conmissioner, on Hoverber 20, 1956, to the Waynesville Reorganized School District Wo. 6, Haynesville, Hissouri, herelnafter called the Agency, to use and occupy for school purposes the school facilities designated as Project No. Mo-56-C-FEN-1A6, on Fort Leonard jood Milltary Reservation, Missouri, provides that "This permit shall remain in effect until terminated by mutual aprement of the parties or revoked by the Comaissioner."

Whereas, the facts and conditions, upon which the Comissioner's authority is based, to make arrangements for the free public education of the children residing on Fort Leonard bood ander section 6 of Public Law 874 , 81st Congress, as amended, have terminated; and whereas House Bill No. 126 recently enacted by the 69th General Assembly of the State of Missouri provides that "Boards of education of six-director districts may operate schools on Federal lands adjoining the district if adequate plant facilities therefor are provided by the Pederal government; ${ }^{n}$ and whereas under the same act the State of Hissouri will provide State aid for pupils residing on Federal lands; the Comissioner hereby declares the permit terminated as of August 29, 1957 (Date)

IN WITNRS WHEREOF AWD BY THE DIRTCTION OF THE CONISSIONER, I have hereunto set my hand and caused the seal of the office of Education 


\section{$-2-$}

to be affixed this $3 /$ st day of
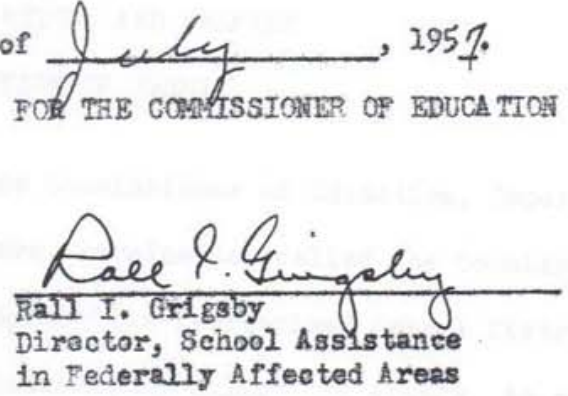

(SEAI)

The Agency hereby consents and agrees to the above provisions and conditions.

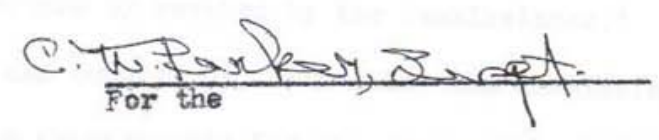

Waynesville Reorganized School District No. 6 Full Legal Name of Agency

\section{Certifleate of Authentication}

I, Claude Ho Morgan, certify that I an the secretary Name of Waynesville Reorganized School District Nocthe Agency hereing that Loeal Educa tional Agency C. W. Parker Nante , who signed this termination of permit on behalf of the Agency, was then superintendent of said Agency; that said temination of permit was dury signed for and in behaj of said Agency by authority of its governing body, and is within the scope of its corporate powers.

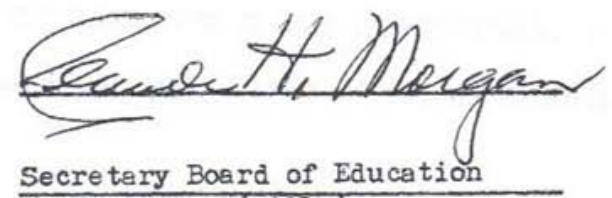
(Tithe) 


\section{Appendix C: Permit for School Purposes}


310, P.L. 815

od under

on 3, P.L. $87 \mathrm{~h}$
(1)

of Education

Washington 25, D.C.

PRRITT FOR SCHOOL PURPOSRS

에

FORT LFONARD WOOD UTLTTARY RESBRTATION WAYNBSVILLE, MISSOURI

The Waynesville Reorganised Sohool District No. 6, Waynesville, Missouri, a

local educational agenoy (hereinafter called the Agency), is hereby granted a permit beginning on the 29th day of August_, 1957, by the connelssioner of Biucation, Department of Heal th, Education, and Welfare (hereinafter called the Commissioner) to use and occupy for school purposes, pursuant to Public Lawe 815 and $87 \mathrm{~h}$, 81at Congress, as amended and the permit dated April 6, 1954, to the Comnissioner from the Secretary of the Arm, all school butldings and other factlities located on the land in the State of Missouri, County of Pulaski, uhich is deseribed at the end hereof, together with all equipment, furnishings and appurtenances (a detailed inventory of which is attached hereto) installed therein or located thereon on the date of this pernit or thereaftar provided by the Coanissioner, 211 of which are hereinafter collectively referred to as the Property.

This pernit is granted subject to the rollowing provisions and oonditions:

1. That the Agency shall conduet in such facilities an education prograr for children residing on Fort Leonard Wood Milltary Beservation as a part of the Agency's achool system in sccordance with the laws of the State of Missouri.

2. That the Agency shall pay all eharges for utilfties and services furnished to the Property. Pryment shall be made direet to the producing on supplying company or to the Department of the Army for the utilities and servioes which are produced or supplied by each, respectively.

3. That the Agency shall use the Property during the term of this pemit for the purpose described above, aubject to such reasonable rules and regulations relative to Ingress, egress, securlty, and non-school use as may be prescribed by the Secretary of the Arny or the officer in charge of the installation silth the approval of the Comnissioner.

4. That the Agency shall maintain and keep the Property in good repair and operating condition (inoluding repair or reconstruction due to dasage occasioned by any risk, such as fire or the elements, to which the Property is exposed) on the present site, and, immediately upon the termination of this pernit as herein provided,

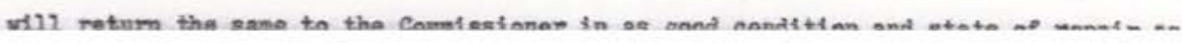


operty is in when delivered to the Agency, reasonable wear and tear and lose

dasage caused by wax excepted. Repair to or reconstruction of property requiring axpenditures in excess of 8500.00 shall be upon plans approved by the Commissioner.

5. (a) That the Ageney shall procure and maintain such insurance covering the risks to which the Property is exposed as the Conalissioner may require, shall promptiy dellver proof of coverage to the Conulsaioner, and shall give due notice to the proper Insurance companies and to the Comnisofioner of any loss or damage to the Property.

(b) That the Comalsaloner mey requitre the Agency to renit to the United States any payment in excess of $\$ 500.00$ received by it pursuant to insurance provided under paragraph $5(\mathrm{a})$. In such event the Agency's obligation to repair or reconstruct under paragraph 4 shall be deemed fulfilled to the extent of the damage for which the paynent ranitted to the Comissioner was made.

6. That the Agency shall pernd the Comaissioner, or his authorized representatives, at any reasonable time to enter upon and inspect the Property, and shall subait current inventories at the Commissioner's request of the equipment, furnishings and appurtenances located in the facilities or on the site.

7. That the Ageney shall save the United States Government and the Commisstoner harmless from any llablitity or claim ardsing from the Ageney's possession, use, ralintenance and operation of the Property or the fulfullment of its obligations hereunder, and if the Agency is insured against tort liabillty in re other school facllities which It owns and operates, it shall carry similar insurance in re the property herein described.

8. That the Agency shall not assign or transfer its rights or interest under this permit, or transfer possession of, or dispose of the Property or any part thereor, or create or permit a lien or charge upon or olaim against the Property or axy part thereof, without the consent of the commissioner evidenced in writing.

9. Thiat the United States Covernment and the Comnissioner assune no liability for any damage, infury, loss, or expanse caused by, resulting from, or arising in connection with the Property or its use, or fros any defeet in or from representations not herein contained made concerning the Property; nor for any part of the cost of operating said Property and conducting an education program thereon, except to the extent to which the Agency is entitied to assiatance under Publif Law 874, 81st Congress, or any subsequent Iegislation in exteneion thereof or in substitution therefor. 
11. That the operation of school facilities located on the Property desoribed herein shall be conducted without segregation on the basis of race or color.

This permit shall remain in effect until terminated by mutumil agreement of the parties or revoked by the Comaissioner. Any of the following reasons shall be a ground for revocation by the Commisefoner:

(a) Termination of the pernit for the use of the land granted to the Coxnilssioner by the Seeretary of the Army under date of Aprill 6, 1954,

(b) Pailure of the Agenoy to operate the Property in accordance with the publle school laws of the State of Missourt;

(c) Patlure or Inabiltty of the Agency to comply with any of the tems or conditions of this permit;

(d) Termination of the facts and conditions upon which the Comenissioner's authority to provide the Property is based; or

(e) Termination of the authority and responsibility of the Conniseioner to provide school faellitieg and free public education for ohildren who restde on Federal establishments under Public Laws 815 and 874 , 81st Congress, or subsequent laws of the United States.

IN WITMRSS WABREOF, AWD BY THB DIRBCTION OF THE COMISSIONBR, I have hereunto sot ny hand and caused the seal of the orfice of Education to be affixed, this ilset. day of

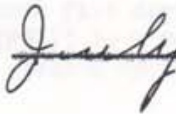
, 1957. FOR THE COAMISSIOHER OF EDUCA TION

(Seal)

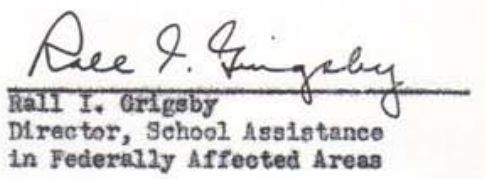

The Agency hereby consents and agrees to the above provisions and conditions.

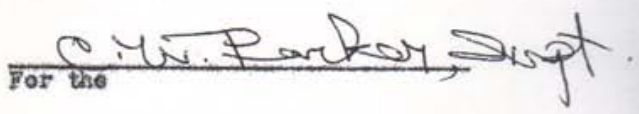

Waynesville Reorganized School District No. 6 Fun Lege: Wame of Agency

\section{Certifleate of Authentication}

I, Claude H, Norgan certify that I ain the secretary

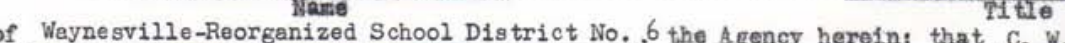
of Waynesville-Reorganized School District No, 6 the Agency herein; that C. W. Parker who signed this pernit on behalf of the Agency, was then superintendent Titie Agency; that said pernit was duly algned for and in behalf of sald Agency by authority of its governing body, and is within the scope of 1 ts corporate powers. 


\section{Appendix D: USOE Permit for Use of Real Property by Federal Agency - Permit No. MO-52-C-FED-1A}


USOE PERMIT FOR USE OF REAL PROPERTY

BY A FEDERAL AGENCY--Permit No. MO-52-C-FED-1A

This AGREEMENT, made and entered this 20 th day of MAy

in the year of 1980 , by and between the United States Commissioner of Education, also known as the PERMITTOR, and the United States Department of the Army, also known as the PERMITTEE, for the purpose of granting permission by the PERMITTOR to the PERMITTEE to use the following described property for the purposes hereinafter described and subject to the conditions contained herein.

1. The property description and location is Pence Elementary School, Fort Leonard Wood, Missouri.

2. The purpose for which the property is to be used is an Army Child Care Center and related functions as may be authorized from time to time by the PERMITTOR upon .. request by the PERMITTEE during the period of this AGREEMENT.

3. This AGREEMENT shall be for a period beginning 1 July 1980 and ending 30 June 1285 , except that such period is subject to termination ofó calendar days advance written notice by either party; and, further, such period may be extended by mutual agreement of both parties.

4. The use and occupancy of the property shall be under the general supervision of the Area Chief, SAFA Program Officer, U. S. Office of Education, Bureau of Elementary and Secondary Education, Division of School Assistance in Federally Affected Areas, Field Operations Branch, Washington, D. C., representing the PERMITTOR.

The representative of the PERMITTEE is designated as the U. S. Army District Engineer, Chief, Real Estate Division, Kansas City, MO.

5. Permission granted and accepted herein shall be without monetary consideration from one party to the other in consideration of the covenants contained herein.

6. This permit is conditional upon State School 59 (State Training School) remaining at the Pence Elementary School.

7. Use and occupancy by the PERMITTEE shall be at no cost to the PERMITTOR, routine administrative expenses excepted. 
8. Additions to or alterations of the property shall be subject to prior written authorization by the PERMITTOR or his authorized representative.

9. The PERMITTEE shall hold harmless the PERMITTOR, its agents and assigns from any liability for claims of any kind arising out of the use by the PERMITTEE of the property; and, further, the PERMITTEE shall do all things necessary and proper to settle or deny liability for all claims made against the United States of America or any of its agents or assigns arising out of such use.

10. On or before the expiration or termination of this AGREEMENT, the PERMITTEE shall vacate the property, remove his personal property therefrom, and restore the premises to the condition at the time of acceptance of this agreement, normal wear and tear excepted.

For the Commissioner

$\operatorname{lng} 2,1980$

For the Department of the Army

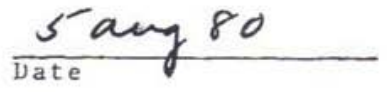

For the School Board

May 20,1980

\section{Wellon h Stammen}

William L. Stormer, Director Division of School Assistance in Federally Affected Areas

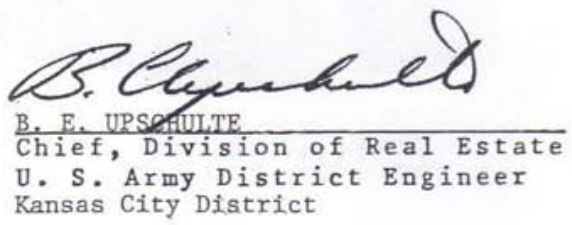

Kansas City District

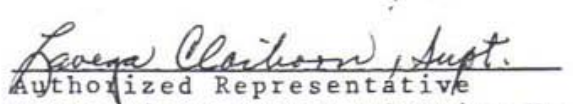
Reorganized School District No. 6 Pulaski County, Missouri 


\section{Appendix E: Return of Pence School, dated April 26, 1994}


To: $\quad$ Mr. G. A. Maxwell

School Liaison Officer

Fort Leonard Wood

From: Erwin Morriss

Superintendent

Waynesville R-VI School District

Date: April 26, 1994

SUBJECTS: 1. RETURN OF PENCE SCHOOL BUILDING

2. ASSISTANCE WITH SPORTS FIELD PROJECT

3. CONSTRUCTION OF PARKING AREA: THAYER SCHOOL

1. The Waynesville School District once again requests the return of the Pence School building for use by the district. Our district request for return of the building was submitted more than four years ago. We are utilizing the bank building owned by Army National Bank for two programs, and both programs have inadequate facilities. Along with those problems, we are needing to expand classroom space for our early childhood and kindergarten programs. The Board and I realize the Army is constructing a child care facility which was discussed with us more than 10 years ago. According to a conversation with General Ballard, that facility should be completed in mid-year, 1995 . The school district respectfully requests a date for transfer so we can do the proper planning for staffing and preparing the building for use.

2. The Thayer School parking and automobile access continues to be a problem. We first requested assistance with that project in or about 1984. Once again I express our need for assistance from the Army for construction of the parking facility. As you are aware, even while our request for a much needed facility rests in file, a parking lot was constructed near the opposite end of the school property without district consultation. My belief is that the traffic flow problem in front of the school is a safety problem and needs to be addressed.

3. The School Board respectfully requests assistance with the earthmoving portion of a sports field construction project at the Waynesville East School property. We have addressed this issue with the City of Waynesville to also get their approval and involvement.

Thanks for vour assistance. I will be pleased to submit more details as necessarv. 
G.A.MAXWELL

Family Support Division

596-0195

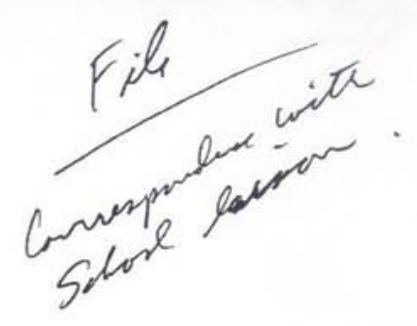

ATZT-CA-FSD

15 April 1994

Return of Pence School to R-VI School District

1. Purpose. To provide information on ownership and return of control of the building being occupied by Pence Child Development Center (CDC).

2. Recommendation. That the CG note the content of this paper.

3. Discussion.

a. The land under Pence has been on under Department of the Army lease to the Commissioner of Education since 1953. The building was constructed by the R-VI school iistrict and is owned by the district. The same principle applies to the other 6 school ouildings on post.

b. In 1980 the installation requested use of the building as a CDC and was issued a use permit in that year. The permit was renewed over the course of the intervening years until June of 1990 .

c. In March 1990 the school district requested return of the building (based on the anticipated construction of the new CDC) effective 1 July 1991. The occupation permit has not been renewed and we are currently occupying the bullding under sufferance of the school district.

d. The school district plans to re-occupy the building as a school housing general and expanded special education missions upon completion of the the new CDC in 1995 .

4. Resource impact. N/A.

None

DCFA

Garrison Cmd 


\section{Appendix F: Assurances, dated December 1999}




\section{ASSURANCES}

Pursuant to the Resolutions of the Waynesville R-VI School District dated May 18, 1998 , and December 20, 1999, to obtain ownership of the Pershing, Partridge, Pence, Pick, Thayer, and Williams Elementary and Wood Middle School facilities located within Fort Leonard Wood, Missouri, and in accordance with section $8008(\mathrm{~b})$ of the Elementary and Secondary Education Act of 1965 (20 U.S.C. 7708(b), formal request is hereby made for transfer of those school facilities from the United States of America, U.S. Department of Education to the Waynesville R-VI School District.

Formal request is also made for the transfer of any equipment provided to these facilities by the United States under Section 10 of Public Law 81-815, 10 USC 2008, or 20 UCS 7708.

Accordingly, the Waynesville R-VI School District (hereinafter referred to as "District") does:

1. Certify that the above-listed school facilities are located within the boundaries of the District.

2. Assert that there is currently a need on a continuing basis for use of the above-listed school facilities by the District for public educational purposes.

3. Give assurance that the above-listed school facilities will be used as long as needed to house the children residing on Federal property for whom they were constructed, and beyond that need will be used to support public educational purposes for the remaining usable life of the facilities.

4. Certify that it has or will acquire leasehold interests in the parcels of real property upon which each of the school facilities is located, including the right of ingress and egress, for a period of at least 25 years, which is equivalent to the remaining usable life of the school facilities, subject to the approval of the United States of America, Department of Defense.

5. Certify further that evidence of the District's actual proposed interest in the real property referred to in item 5 , above, will be presented to the United States of America, Department of Education before title to the above-listed school facilities is transferred to the District.

6. Give assurance that the educational program provided in the abovelisted school facilities will be conducted without discrimination on the basis of race, color, sex, or national origin. 
Page 2 - Assurances

7. Assert that the Missouri Department of Education has certified that:

a. The Waynesville R-VI School District is legally authorized, under State law, to spend State or local funds to construct, repair, maintain, and operate school facilities for public educational purpose on lands leased to it from the United States of America; and

b. The use of school facilities by the District is not inconsistent with overall State plans for providing school facilities in the State.

8. Certify that it will record the Quitclaim Deed to be executed between the U.S. Department of Education and the District with the appropriate recorder of deeds within ten days after the Quitclaim Deed and the Acceptance are executed.

9. Certify that will will provide the U.S. Department of Education with a copy of the Quitclaim Deed within ten days after it is recorded.

Having fulfilled these assurance, the Waynesville R-VI School District requests the transfer of the facilities as described in Exhibit " $A$ " of this document, together with the equipment contained therein. A list of such equipment contained in each school facility, as recorded on the District's general fixed asset accounts, will be provided. The aforementioned school facilities and school equipment were originally provided for under either Public Law 81-815 section 10, 10 USC 2008, or 20 USC 7708.

These assurance are made upon the understanding that transfer of the above-listed school facilities will be effected upon receipt of these assurance and approval of the equipment lists.

Waynesville R-VI School District Acting by and through

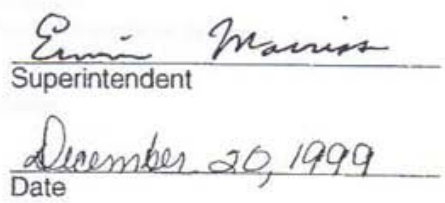




\section{Appendix G: Permit Termination Agreement for Department of Education School Located on Fort Leonard Wood}




\title{
PERMIT TERMINATION AGREEMENT FOR DEPARTMENT OF EDUCATION SCHOOLS LOCATED ON
}

\author{
FORT LEONARD WOOD \\ PULASKI COUNTY, MISSOURI
}

THIS PERMIT TERMINATION AGREEMENT is made by and between the Secretary of the Army (Permittor) and the Department of Education (Permittee) effective upon the date of execution by both parties.

WHEREAS: The Secretary of the Army granted seven (7) separate permits to the Department of Education (A.K.A. Commissioner of Education, Department of Health, Education and Welfare) to use and occupy, for school purposes, seven (7) separate parcels of land on the Fort Leonard Wood Military Installation, Missouri, between 5 August 1953 and 1 April 1962; and

WHEREAS: The Department of Education in accordance with 20 U.S.C. Section 7708 , has proposed to terminate the seven (7) existing permits located on the Fort Leonard Wood Military Installation, Missouri and transfer all capital improvements to the Waynesville R-VI School District (the local school district) by individual "quit claim deeds," over a period of time; and

WHEREAS: The preparation and execution of a new lease between the Secretary of the Army and the local school district (to replace the existing permits) is required in order to transfer ownership of the capital improvements to the local school district; and

WHEREAS: Title 10, United States Code, Section 2667 authorizes the Secretaries of the military departments to grant leases to local school districts for this purpose.

WHEREAS: The termination of the existing permits will allow the execution of a new lease for each site to the local school district for a period of not less than 25 years.

NOW THEREFORE: The Permittor and Permittee have entered into this Permit Termination Agreement and agree:

1. The Secretary of the Army granted seven (7) separate permits to the Department of Education (A.K.A. Commissioner of Education, Department of Health, Education and Welfare) to use and occupy for school purposes, seven (7) separate parcels of land on the Fort Leonard Wood Military Installation, Missouri, as identified by reference below:

FORT LEONARD WOOD, MISSOURI LEASE NO. DACA41-1-99-501

WAYNESVILLE R-VI SCHOOL DISTRICT EXHIBIT "D" 
a. Permit No. 084-15 for Pence Elementary School, effective 5 August 1953 for 2.30 acres.

b. Permit No. 084-20 for Pick Elementary School, effective 5 May 1958 for 11.76 acres.

c. Permit No. DA23-028-ENG-3791 for Thayer Elementary School, effective 10 April 1959 for 13.30 acres.

d. Permit No. DA23-028-ENG-4493 for Wood Junior High School, effective 1 August 1960 for 22.03 acres.

e. Permit No. DA23-028-ENG-4494 for Williams Elementary School, effective 1 August 1960 for 10.4 acres.

f. Permit No. DA23-028-ENG-5130 for Partridge Elementary School, effēctive 1 April 1962 for 14.90 acres.

g. Permit No. 084-16 for Pershing Elementary School, effective 8 November 1955 for 12.87 acres.

2. Both parties agree that each permit shall be terminated effective upon the execution date of each replacement lease. From and after the termination date, each permit will be of no further force and effect, and each party will be released from any further obligations under the permit, except for those obligations that accrued prior to the termination date and any obligations that survive termination according to the permit or by law.

3. The Permittee shall notify the Secretary of the Army each time it desires to transfer ownership of the capital improvements of one or more of the seven (7) parcels of land identified in paragraph 1 of this Termination Agreement to the local school district. Upon receiving said notice, the Secretary of the Army shall prepare each lease document to be entered into between the Secretary of the Army and the local school district.

4. All correspondence and notices to be given pursuant to these leases shall be addressed, if to the Permittee, to Catherine Schagh, Director, Impact Aid Program, U.S. Department of Education, 400 Maryland Ave., S.W., Washington, D.C. $20202-6244$ and, if to the Permittor, to the District Engineer, Attention: Chief, Real Estate Division, Kansas City District, 860 Federal Building, P.O. Box 15339,601 East $12^{\text {th }}$ Street, Kansas City Missouri $64106-2896$, or as may otherwise be directed from time to time by the parties. Notice shall be deemed to have been duly given if and when enclosed in a properly sealed envelope, or wrapper, addressed as aforesaid, and deposited postage prepaid in a post office regularly maintained by the United States Postal Service, or sent by other commercial carrier.

5. The Permittee agrees that delivery of each executed lease document to the Permittee at the above address shall constitute notice of permit termination for the property subject to the delivered lease document. The Permittee hereby acknowledges that it will not be a party to the lease documents, which will be executed by the Secretary of the Army and the local school district. 
Permit Termination Agreement fo Department of Education Schools

As evidenced below, the parties hereby accept this Permit Termination Agreement.

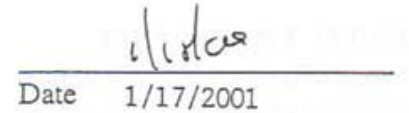

$\frac{6 / 12 / 2001}{\text { Date }}$
THE DEPARTMENT OF EDUCATION

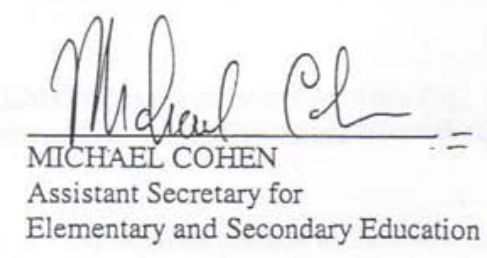

THE DEPARTMENT OF THE ARMY

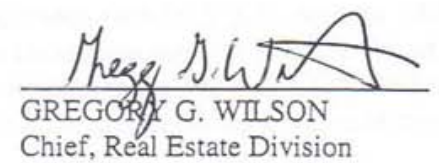




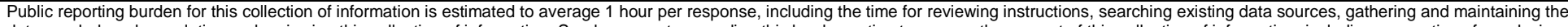

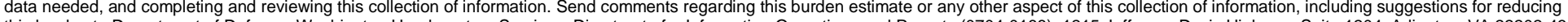

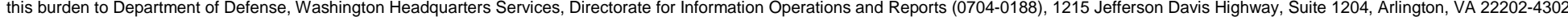

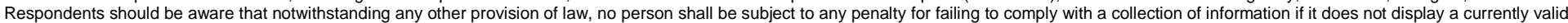
OMB control number. PLEASE DO NOT RETURN YOUR FORM TO THE ABOVE ADDRESS.

\begin{tabular}{l|c|c|}
\hline 1. REPORT DATE (DD-MM-YYYY) & 2. REPORT TYPE & 3. DATES COVERED (FrOm - TO
\end{tabular}

\section{TITLE AND SUBTITLE}

Final

Architectural Survey of Pence Elementary School, Fort Leonard Wood, Missouri

5a. CONTRACT NUMBER

5b. GRANT NUMBER

5c. PROGRAM ELEMENT

6. AUTHOR(S)

Sunny Adams, Chris J . Cochran, and Adam Smith

5d. PROJECT NUMBER

MIPR

5e. TASK NUMBER

10042772

5f. WORK UNIT NUMBER

7. PERFORMING ORGANIZATION NAME(S) AND ADDRESS(ES)

U.S. Army Engineer Research and Development Center (ERDC)

Construction Engineering Research Laboratory (CERL)

PO Box 9005

Champaign, IL 61826-9005

8. PERFORMING ORGANIZATION REPORT NUMBER

ERDC/ CERL TR-11-25

\section{SPONSORING / MONITORING AGE NCY NAME(S) AND ADDRESS(ES)}

Fort Leonard Wood

Directorate of Public Works Environmental Division

Fort Leonard Wood, Missouri 65473

\section{DISTRIBUTION / AVAILABILITY STATE MENT}

Approved for public release; distribution is unlimited.
10. SPONSOR/MONITOR'S ACRONYM(S)

11. SPONSOR/MONITOR'S REPORT NUMBER(S)

\section{SUPPLEME NTARY NOTES}

\section{ABSTRACT}

This document is an architectural survey of Building 6824, Pence Elementary School, constructed in 1954 at Fort Leonard W ood, M issouri. This survey was initiated for a Section 106 process and satisfies Section 110, both of the National Historic Preservation A ct of 1966 as amended. The work was used to determine the eligibility of the school for inclusion on the National Register of Historic Places (NRHP). It is the determination of this report that Pence Elementary School is not eligible to the NRHP because it is not individually significant and is not part of a larger historic district.

\section{SUBJ ECT TERMS}

Fort L eonard W ood, M issouri, National Register of Historic Places (NRHP), cultural resources management, Pence Elementary School, historic buildings

\begin{tabular}{|c|c|c|c|c|c|}
\hline 16. SECURITY C & IFICATION OF: & & 17. LIMITATION & 18. NUMBER & 19a. NAME OF RESPONSIBLE PERSON \\
\hline $\begin{array}{l}\text { a. REPORT } \\
\text { Unclassified }\end{array}$ & $\begin{array}{r}\text { b. ABSTRACT } \\
\text { Unclassified }\end{array}$ & $\begin{array}{l}\text { c. THIS PAGE } \\
\text { Unclassified }\end{array}$ & UU & 170 & $\begin{array}{l}\text { 19b. TELEPHONE NUMBER } \\
\text { (include area code) }\end{array}$ \\
\hline
\end{tabular}

